This report was prepared as an account of work sponsored by an agency of the United States Government. Neither the United States Government nor any agency thereof, nor any of their Jemployees, makes any warranty, express or implied, or assumes any legal liability or responsibility for the accuracy, completeness, or usefulness of any information, apparatus, product, or process disclosed, or represents that its use would not infringe privately owned rights. Reference herein to any specific commercial product, process, or service by trade name, trademark, manufacturer, or otherwise does not necessarily constitute or imply its endorsement, recommendation, or favoring by the United States Government or any agency thereof. The views and opinions of authors expressed herein do not necessarily state or reflect those of the United States Government or any agency thereof.

\title{
The Salton Sea Geothermal Field, California, as a Near-Field Natural Analog of a Radioactive Waste Repository in Salt
}

Technical Report

November 1983

\author{
Wilfred A. Elders \\ Lewis H. Cohen \\ of \\ Institute of Geophysics and Planetary Physics \\ University of California, Riverside \\ prepared for \\ Office of Nuclear Waste Isolation \\ Battelle Memorial Institute \\ 505 King Avenue \\ Columbus, OH 43201
}

BMI/ONWI --513

DE84 003851

The content of this report was effective as of June 1983. This report was prepared by "Institute of Geophysics and Planetary Physics, University of California, Riverside, under Subcontract E512-08300 with Battelle Project Management Division, Office of Nuclear Waste Isolation under Contract Nos. DE-AC0676RLO1830 and DE-AC02-83CH10140 with the U.S. Department of Energy. 


\section{DISCLAIMER}

This report was prepared as an account of work sponsored by an agency of the United States Government. Neither the United States Government nor any agency Thereof, nor any of their employees, makes any warranty, express or implied, or assumes any legal liability or responsibility for the accuracy, completeness, or usefulness of any information, apparatus, product, or process disclosed, or represents that its use would not infringe privately owned rights. Reference herein to any specific commercial product, process, or service by trade name, trademark, manufacturer, or otherwise does not necessarily constitute or imply its endorsement, recommendation, or favoring by the United States Government or any agency thereof. The views and opinions of authors expressed herein do not necessarily state or reflect those of the United States Government or any agency thereof. 


\section{DISCLAIMER}

Portions of this document may be illegible in electronic image products. Images are produced from the best available original document. 


\section{i $/$ ii}

\section{ACKNOWLEDGMENTS}

Our knowledge of the Salton Sea Geothermal Field has been gained during the last decade as a result of work performed under grants and contracts to the Geothermal Resources Project at UCR from the U.S. Department of Energy, the United States Geological Survey, and the National Science Foundation. We are grateful to our colleagues and students in this project who have contributed so much to our education in geothermics and to the companies that have released samples and data from their wells. We thank Lori Paustell for typing and Linda Jankov for illustrating the manuscript. Finally we are especially appreciative to Dr. J. B. Moody of ONWI for the stimulus and guidance in writing this report.

This is report no. UCR/IGPP-83/10 of the Institute of Geophysics and Planetary Physics, University of California, Riverside, California. 

Since high concentrations of radionuclides and high temperatures are not normally encountered in salt domes or beds, finding an exact geologic analog of expected near-field conditions in a mined nuclear waste repository in salt will be difficult. The Salton Sea Geothermal Field, however, provides an opportunity to investigate the migration and retardation of naturallyoccurring $\mathrm{U}, \mathrm{Th}, \mathrm{Ra}, \mathrm{Cs}, \mathrm{Sr}$ and other elements in hot brines which have been moving through clay-rich sedimentary rocks for up to 100,000 years.

The more than thirty deep wells drilled in this field to produce steam for electrical generation penetrate sedimentary rocks containing concentrated brines where temperatures reach $365 \mathrm{C}$ at only $2 \mathrm{~km}$ depth. The brines are primarily $\mathrm{Na}, \mathrm{K}$, Ca chlorides with up to 25 percent of total dissolved solids; they also contain high concentrations of metals such as $\mathrm{Fe}, \mathrm{Mn}, \mathrm{Li}, \mathrm{Zn}$, and $\mathrm{Pb}$.

This report describes the geology, geophysics and geochemistry of this system as a prelude to a study of the mobility of naturally-occurring radionuclides and radionuclide analogs within it. The aim of this study is to provide data to assist in validating quantitative models of repository behavior and to use in designing and evàluating waste packages and engineered barriers. 
TABLE OF CONTENTS

Page

1 EXECUTIVE SUMMARY . . . . . . . . . . . . 1

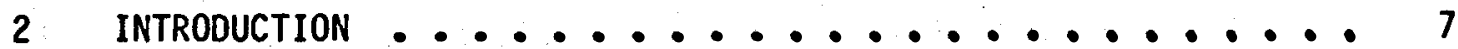

2.1 WASTE ISOLATION IN SALT .............. 7

2.1 .1 Rock Salt .................. 7

2.1.2 Expected Repository Conditions ......... 8

2.1.3 Duration of Isolation ............ 11

2.2 NATURAL ANALOG STUDIES ...................... 14

2.2 .1 Purpose .................. 14

2.2.2 Choice of the Salton Sea Field ......... 15

3 GEOTHERMAL SYSTEMS OF THE SALTON TROUGH . . . . . . . 16

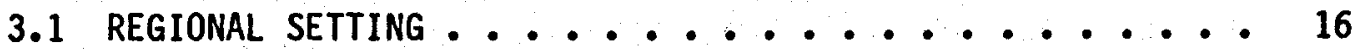

3.2 STRATIGRAPHY AND SEDIMENTATION . . . . . . . . . 16

3.3 SEISMICITY AND STRUCTURE OF THE SALTON TROUGH . . . . 21

3.4 VOLCANISM IN THE SALTON TROUGH ............ 29

3.5 STRUCTURAL EVOLUTION OF THE SALTON TROUGH ....... 33

3.6 HYDROTHERMAL SYSTEMS IN THE SALTON TROUGH . . . . . 39

3.6.1 Regional Picture ............ 39

3.6 .2 Heat Sources .............. 41

3.6.3 Models of the Cerro Prieto Geothermal System . . 42

3.7 GROUND WATER IN THE SALTON TROUGH ........... 47

3.7.1 Oxygen and Hydrogen Isotope Investigations .... 47

3.7 .2 Brine Types ............... 50

4 THE SALTON SEA GEOTHERMAL FIELD — . . . . . . . 52

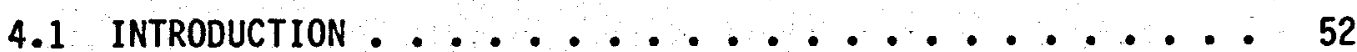

4.1 .1 Resource Estimates . . . . . . . . . 52

4.1.2 History of Development .......... 53

4.1.3 Previous Opportunities for Studies of the SSGF . . 58

4.1.4 Some Previous Publications on the SSGF ..... 58 
TABLE OF CONTENTS (cont.)

4.2 Page 4.2.1 Gravity Anomalies ............ 59

4.2.2 Magnetic Anomalies .............. 59

4.2 .3 Seismic Velocity ............ 62

4.2 .4 Resistivity ............... 62

4.2.5 Faulting and Seismicity in the SSGF ...... 64

4.2.6 Temperatures and Heat Flow within the SSGF ... 66

4.3 BRINE CHEMISTRY IN THE SSGF .......... 73

4.3.1 Brine Chemistry ............. 75

4.3.2 Source of the Brine ........... 79

4.3.3 Source of the Metals ........... 83

4.3.4 Pipe Scales from the Early Wells ........ 84

4.4 SUBSURFACE GEOLOGY OF THE SSGF ........... 88

4.4 .1 Parastratigraphy ............ 88

4.4 .2 Subsurface Structure ........... 95

4.4.3 Influence of Structure on Heat Transfer .....99 95

4.5 WATER/ROCK REACTIONS ................ 99

4.5.1 Mineralogy of the Sediments of the Reservoir ... 100

4.5.2 Hydrothermal Al teration Textures . . . . . 101

4.5.3 Hydrothermal Mineral Zones .......... 101

4.5.4 Phase Relations of Authigenic Minerals . . . 106

4.5.5 Ore Mineralization in the SSGF ....... 109

4.5.6 Light Stable Isotopes in the Sediments of the SSGF ............... 111

4.5.7 Fracture Formation and Vein Minerals

in the SSGF ................. 113

4.5.8 Correlation of Wireline Logs with Petrology .... 114

5 THE ON-GOING STUDY OF THE SSGF .................. 119

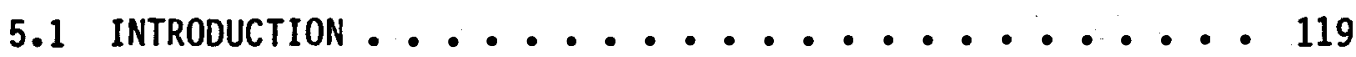

5.2 PROBLEMS OF ACCESS TO SAMPLES .......... 119

5.3 FUTURE STUDIES ............... 120 
vii

\section{LIST OF FIGURES}

Figure 2-1. Maximum Rock Salt Temperatures Based on Different

Initial Thermal Loads in Model Radioactive Waste Repositories in Rock Salt ............. 9

Figure 2-2. Relative Toxicity of Equivalent Amounts of Uranium Ore, Spent Fuel, and High-level Waste ........ 13

Figure 3-1. Geothermal Fields of the Salton Trough ........ 17

Figure 3-2. Regional Stratigraphy of the Imperial Valley . . . . 20

Figure 3-3. Epicenters with Relative Horizontal Location Errors Less than $2.5 \mathrm{~km}$ for Interval June 1973 Through November 1978 Which Included Several Earthquake Swarms .................. 23

Figure 3-4. (A) Regional Bouguer Gravity Anomalies of Southern California from the Continental Borderland to the Colorado River. (B) One Crust-Mantle Model, Computed Along the Line $E^{\prime}$ in $(A)$, Showing the Thinner Crust Beneath the Salton Trough ............ 25

Figure 3-5. Seismic Velocity with Depth in the Salton Trough . . . 28

Figure 3-6. East-Northeast Section Across the Salton Trough . . . 30

Figure 3-7. Model of Rifting and Magma Generation for the

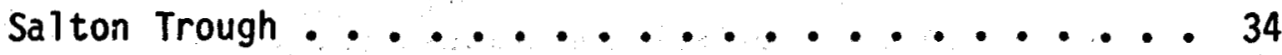

Figure 3-8. Plate-tectonic Model and Map of Northern Gulf of California and Salton Trough .......... 37 


\section{viii}

\section{LIST OF FIGURES (cont.)}

Page

Figure 3-9. SW-NE Cross-section Showing the Flow Regime Proposed for Cerro Prieto .............. . . 44 44

Figure 3-10. Two-dimensional Heat Transfer Model for the Cerro Prieto Geothermal Field ............ 46

Figure 3-11. $\delta D$ Versus $\delta^{18} 0$ of Hydrothermal and Well Water Samples from the Imperial Valley Area .......... 49

Figure 4-1. Location of Existing and Proposed Geothermal Wells in the Salton Sea and Westmorland Geothermal Areas .... 55

Figure 4-2. Bouguer Gravity Anomaly Map of the Area Around the Salton Sea Geothermal Field ............. 60

Figure 4-3. Map Showing the Salton Buttes Volcanoes, Selected Geothermal Wells, Magnetic Anomalies, and Magnetic Contours .................. 61

Figure 4-4. Seismic Refraction Profile from Obsidian Butte to the Alamo River............... 63

Figure 4-5. Location of Faults and Earthquake Epicenters in the Salton Sea Geothermal Field Area for the Period October 1, 1976 Through December 31, $1976 \ldots 65$

Figure 4-6. Equilibrium Temperature Profiles for 13 Wells in the Salton Sea Geothermal Field ........... 67

Figure 4-7. Location of Boreholes and Isotherms at $914 \mathrm{~m}$ (3000 ft) Depth in the Salton Sea Geothermal Field . . . . . 68 


\section{LIST OF FIGURES (cont.)}

Page

Figure 4-8. North-south Section Across the Salton Sea Geothermal

Field Showing the Thermal Lithologic Caps . . . . . 70

Figure 4-9. Temperature Profiles of Westmorland Geothermal We11s . 72

Figure 4-10. Equilibrium Temperature Logs for Elmore №. 1 and Britz No. 3 Wells, Together with the Boiling Point Curves for Pure Water and a $25 \% \mathrm{NaCl}$ Solution ..... 74

Figure 4-11. Fence Diagram Showing Well Depth, Perforated Interval, and Formation Fluid Salinity for Selected Wells in the Salton Sea and Westmorland Geothermal Areas ...... 81

Figure 4-12. Average Salinity Versus Homogenization Temperature of Fluid Inclusions in Well sinclair 4........ 82

Figure 4-13. East-west Cross Section Through the Magmamax and Wool sey Wells in the Salton Sea Geothermal Field ... 92

Figure 4-14. Depth of the Base of the Sedimentary Caprock ..... 93

Figure 4-15. Measured Porosity Versus Depth for Cores from Five Geothermal Wells in the Salton Sea Geothermal Field ... 96

Figure 4-16. Parastratigraphy of the Buttes Area ......... . 97

Figure 4-17. Spontaneous Potential (SP) Log Correlations of Five Wells Extending North to South from Elmore No. 1 to Sinclair No. 3 in the Salton Sea Geothermal Field . . . 98

Figure 4-18. Summary of Lithologic, Temperature, Authigenic Mineral Variation, and Sandstone Mineral Zones in Elmore No. 1. 103 


$$
\frac{x}{\text { LIST OF FIGURES (cont.) }}
$$

Page

Figure 4-19. Calcite and Epidote Veins in Shale from $900 \mathrm{~m}$ Depth in the Salton Sea Geothermal Field ......... 115

Figure 4-20. Wel1 Log Data Versus Depth for Magmamax No. 2 . . . 118 


\section{LIST OF TABLES}

Page

Table 2-1. Maximum Temperatures in the Rock Salt, Canister

Surface, and Waste Centerline .......... 10

Table 2-2. Compositions of Waste Isolation Pilot Plant Brines A and B .................. 12

Table 3-1. Chemical Analysis of Volcanic Rocks in the Salton Trough ................. 32

Table 4-1. Chemical Compositions of Salton Sea Brines . . . . 76

Table 4-2. Changes in Brines Composition During Production of Magmamax No. 1............... 78

Table 4-3. Chemical and Isotopic Data for Fluids Produced from the Westmorland Geothermal System .......... 80

Table 4-4. Sulfide Minerals in Pipe Scales from the SSGF . . . . 85

Table 4-5. XRF Analyses of Sulfide-Rich Layers of Well Scales in I.I.D. No. 1.................. 86

Table 4-6. Quantitative Spectrographic Analyses of Sulfide-Rich scale in I.I.D. No. 1...............

Table 4-7. "Typical" Analysis for Magmamax No. 1 and Sinclair No. 4 Brines ........... 89

Table 4-8. Analyses of Scale from Magmamax No. 1 Wellhead and the LLNL Four-stage Flash System After $~ 720 \mathrm{H}$ of Operation ...................... 


\section{xii}

\section{LIST OF TABLES (cont.)}

Page

Table 4-9. Summary of Authigenic Mineral Assemblages, Elmore No. 1, Salton Sea Geothermal Field ............ 105

Table 4-10. Characteristic Log Response and Hudrothermal Mineralogy Within the Four Mineral Zones . . . . . 117 


\section{EXECUTIVE SUMMARY}

The purpose of this document is to review the present status of knowledge of the geology, geochemistry and geophysics of the Salton Sea Geothermal Field (SSGF). A comprehensive investigation of the occurrence and migration of radionuclides within this geothermal system is now underway. The results of this new study and their relevance to problems of waste isolation in salt will be the subject of future reports. The present report therefore describes the geology of the SSGF and points out the potential it offers as a natural laboratory for studying water-rock reactions and material transport in hot highly saline solutions. This geothermal field offers a number of advantages as a site for analog studies of radionuclide migration. Measurements of the temperature field can be made, and samples of rock and brine obtained. Similarly, measurements of permeability and porosity can be made and inferences derived on natural rates of heat and mass transfer. Since geothermal systems normally have lifetimes of 100,000 years or less, the effects of migration and retardation of naturally-occurring radioactive elements by the action of hot brines moving through clay-rich rocks over long periods of time can be studied directly.

The geothermal fields of the Salton Trough in California were chosen as best representing temperature-salinity analogs for a waste repository in salt. All of these geothermal fields contain argillaceous rocks and have. temperatures bracketing those which are expected in high-level nuclear waste repositories. In addition, they contain alkali chloride brines ranging in concentration from 3,000 to $285,000 \mathrm{ppm}$ total dissolved solids (TDS) in the different fields.

The Salton Trough is a faulted basin which forms the landward extension of the Gulf of California. This region marks the transition between the extensional tectonics of the East Pacific Rise and the transform fault tectonics of the San Andreas fault. The Trough is partially filled by terrigeneous deltaic sediments deposited by the colorado River in Late Tertiary to Recent times. It is an area of high seismicity and is characterized by pronounced positive gravity, magnetic, and heat-flow anomalies. Models suggest that there has been marked thinning or dilation of 
the continental crust; the consequent emplacement of new crust with decided oceanic characteristics produces a basement of mafic igneous rocks. Although the two occurrences of Quaternary volcanic rocks in the Salton Trough are siliceous in composition, they have primitive or depleted ${ }^{87} \mathrm{Sr} /{ }^{86} \mathrm{Sr}$ ratios suggesting that they were mantle-derived magmas.

The major geothermal fields in the Trough are associated with en echelon fault systems which are local zones of crustal dilation. Best known is the Cerro Prieto field in Mexico, which has been extensively drilled and studied. Magnetic, gravity, and heat transfer modelling of this field suggests that its heat source is a gabbro intrusion 3 to $5 \times 10^{4}$ years old, some 4 to $5 \mathrm{~km}$ across, with a top at a depth of 5 to $6 \mathrm{~km}$.

Light stable isotopic studies of ground waters in the Trough show that the waters are derived both from connate and partially evaporated Colorado River water. Studies of dissolved solids recognize several different brine types formed by various mixtures of river water, local precipitation, and hypersaline freshwater evaporite.

The SSGF is the largest, hottest, and most saline geothermal field in the U.S. part of the Salton Trough. Temperatures as high as $365 \mathrm{C}$ with brines up to $280,000 \mathrm{ppm}$ TDS are encountered at depths as shallow as $2,100 \mathrm{~m}$ in Plio-Pleistocene sediments. Fluid pressure in the reservoir is hydrostatic for the brine, with a gradient of $0.098 \mathrm{bars} / \mathrm{m}$. This geothermal field has been penetrated by more than 32 deep wells and has an estimated volume exceeding $115 \mathrm{~km}^{3}$ to an explored depth of $3 \mathrm{~km}$. The SSGF is therefore the most extensive known hot brine hydrothermal system in North America undergoing commercial development.

The SSGF brines are concentrated sodium, potassium, calcium chloride solutions containing some of the highest concentrations of dissolved metals known in nature. Typical values of dissolved constituents in published analyses are: Cl 83,000-155,000 ppm, Na 40,000-59,000 ppm, Ca 13,000-59,000 ppm, K 7,000-15,000 ppm, Fe 200-1,200 ppm, Mn 500-1,100 ppm, Zn 300-800 ppm, Li 90-287 ppm, Silica 180-400 ppm, Pb 40-100 ppm, Cu 0.5-8 ppm, Ag 0.8-1.4 $\mathrm{ppm}$. The very high concentrations of the brines is now believed to be derived from dissolution of non-marine evaporites associated with lacustrine rocks and the altered deltaic sediments which constitute the reservoir rock of the SSGF. $A$ recent estimate of the potential for recovery of minerals from a $1,000-M W e$ 
combined geothermal power and mineral recovery plant in this field indicated a high economic potential for these dissolved materials. The market value of the power was estimated at $\$ 394 \mathrm{million} / \mathrm{year}$ whereas the value of the mineral production could range from $\$ 500$ to $\$ 1,500$ million/year.

The sediments in the reservoir consist of a mixture of deltaic, quartzofeldspathic sandstones, with clay or carbonate cements, interbedded with lacustrine mudstones and siltstones. Detrital phyllosilicates in these rocks are chiefly montmorillonite, illite, and kaolinite, as well as lesser amounts of coarser-grained detrital biotite, chlorite, and muscovite. The gross stratigraphy in the drilled part of the field consists of an upper clay-silt-evaporite lacustrine sequence 400 to $500 \mathrm{~m}$ thick in the center of the field, and a lower, interbedded sand-shale sequence.

In response to the elevated temperatures, active metamorphism occurs in this field at moderate depth. First there is a zone of intensive carbonate precipitation that forms a self-sealed caprock below the lacustrine sequence. With increasing temperature and depth, a series of decarbonation and dehydration reactions causes progressive breakdown of clay and carbonate minerals. At the highest temperatures encountered, these reactions produce a metamorphic mineral assemblage somewhat similar to the greenschist metamorphic facies. Similarly there are abundant and diverse metal sulfides, sulfates and oxides being formed in different parts of the system.

Four metamorphic zones are therefore recognized:

(1) a dolomite/ ankerite zone (at temperatures $\langle 190 \mathrm{C}$ ), in which mixed-layer 111 ite/smectite also occurs with calcite, hematite, quartz and sphene; (2) a calcite-chlorite zone (at 190-325 C), accompanied by illite/phengite, quartz, albite, adularia, epidote, pyrite, sphene, sphalerite, and anhydrite; (3) a biotite zone (at 325-365 C) in which vermiculite, talc, quartz, orthoclase/microcline, albite, epidote, pyrite, actinolite, sphene and minor amounts of muscovite, chlorite, anhydrite and sphalerite also occur; and (4) a garnet zone (at $>360 \mathrm{C}$ ) in which andradite garnet occurs with biotite, quartz, albite, epidote, actinolite, pyrite, and sphene.

At temperatures below $190 \mathrm{C}$ the rocks retain their detrital fabric. Between 250 to $300 \mathrm{C}$ pore filling by calcite and epidote, overgrowth on framework minerals, and eventual recrystallization progressively form granoblastic textures. Above $350 \mathrm{C}$ few vestiges of the original detrital 
textures remain and the rock tends to acquire a hornfelsic texture. These changes in mineralogy and texture are accompanied by corresponding decreases in porosity, from typically 15-20 percent in the calcite zone to 5 percent in the biotite zone, together with corresponding increases in rock density. As these changes occur, however, vein minerals become more abundant. These observations indicate that one result of increased temperature is that matrix permeability declines and fracture permeability increases. The veins record abundant evidence for repeated opening and sealing of fractures. Such fracture opening may be caused by either hydraulic or seismic failure.

Incipient sulfide and oxide mineralization accompanies the metamorphism mentioned above. Major ore minerals found are, in order of decreasing abundance, pyrite, hematite, sphalerite, chalcopyrite, pyrrhotite, marcasite, and galena. Ore mineralization can be divided into three main types:

(1) diagenetic sulfide mineralization, occurring at depths less than $760 \mathrm{~m}$ and temperatures less than $250 \mathrm{C}$; (2) metamorphic sulfide mineralization, occurring at depths greater than $760 \mathrm{~m}$ and temperatures greater than $250 \mathrm{C}$; and (3) vein-related sulfide and oxide mineralization, occurring in restricted intervals at depths greater than $760 \mathrm{~m}$.

The textures of the ore minerals in the SSGF indicate that early-formed diagenetic iron sulfides are both nuclei and sources of sulfur and iron for later diagenetic, metamorphic, and hydrothermal sulfide and oxide mineralization. Most later $\mathrm{Cu}-\mathrm{Pb}-\mathrm{Zn}$ sulfides and iron oxides replace earlier diagenetic and porphyroblastic pyrite. $\mathrm{Cu}, \mathrm{Pb}$, and $\mathrm{Zn}$ are derived mainly from the immediately surrounding sediments. Sulfide precipitation is apparently controlled by accessibility of sulfur-poor brines to earlier formed pyrite.

Thermodynamic analysis of the phase relations among aqueous solutions and minerals in the system $\mathrm{Na}_{2} \mathrm{O}-\mathrm{K}_{2} \mathrm{O}-\mathrm{CaO}-\mathrm{MgO}-\mathrm{Fe}_{2} \mathrm{O}_{3}-\mathrm{Al}_{2} \mathrm{O}_{3}-\mathrm{SiO}_{2}-\mathrm{H}_{2} \mathrm{O}-\mathrm{CO}_{2}-\mathrm{HCl}$ has been performed for the mineral assemblages observed in the Salton Sea geothermal system. Aqueous species activity ratios $a_{\mathrm{Na}}+/ a_{H^{+}}$and $a_{K^{+}} / a_{H^{+}}$increase several tenths of a $\log$ unit as depth and temperature increase 250 to $350 \mathrm{C}$, whereas ${ }^{a} \mathrm{Ca}^{2}+/ \mathrm{a}^{2} \mathrm{H}^{+}$decreases two orders of magnitude over this temperature range. The fugacity of $\mathrm{CO}_{2}$ gas is 1.5 bars at $\leq 310 \mathrm{C}$. Thermodynamic analysis of the vein ore mineral assemblages and brines indicates that the presently produced brines are in equilibrium with the open, porous, hematite-dominated vein assemblage at $300 \mathrm{C}$, with in situ $\mathrm{pH}=5.4$ and $\log \mathrm{f}_{\mathrm{O}_{2}}=-30$. Calculated 
metal-chloride complex solubilities for $\mathrm{Cu}, \mathrm{Pb}$, and $\mathrm{Zn}$ also agree well with the brine analyses.

The earliest ideas on the origin of the dissolved metals in this system suggested that they were derived from the associated volcanic rocks. However, $\mathrm{B}, \mathrm{Li}, \mathrm{NH}_{4}, \mathrm{Sr}$ and $\mathrm{Pb}$ are now thought to be derived by leaching from the sediments. For example, isotopic evidence indicates at least 80-100 percent of $\mathrm{Sr}$ and 50-100 percent of $\mathrm{Pb}$ has been leached from the Colorado River delta sediments by interaction with hot brines. Although this does not preclude the possibility of some other metals derived from a magmatic source, textural evidence suggests that the major source of $\mathrm{Cu}, \mathrm{Pb}$, and $\mathrm{Zn}$ is derived from the shales.

The content of total ore metals in the brine exceeds total sulfur by a factor of 8 on a molal basis, with the brine apparently saturated with respect to sulfide components. The origin of sulfur in this system is still not entirely understood. The sulfur in early-formed synsedimentary/diagenetic iron sulfides is probably derived from inorganic sulfate that has been reduced by bacteria. The occurrence of evaporites in the shallow sedimentary sequence suggests that sulfate was transported in Colorado River water and concentrated in the Salton Basin. The $\delta^{34} S$ values in the sulfides and sulfates in the reservoir, on the other hand, support a magmatic source, either directly or by erosion of igneous rocks with primitive sulfur.

An extensive investigation of the migration and retardation of naturally occurring analogs to radionuclides in the Salton Sea system is now underway. The concentration of uranium in brine from the SSGF is reported to be $\simeq 10 \mathrm{ppb}$. Preliminary analysis data of typical rock cores from the SSGF indicate the following concentrations of analog elements: U 1.3-5.3 ppm, Th 2.5-24.4 ppm, $\mathrm{Sr}$ 181-534 ppm, and Cs 0.5-7.5 ppm. From radiography, uranium is found almost exclusively associated with very fine-grained (0.01-0.005 $\mathrm{mm}$ ) matrix minerals including clay minerals, illite, chlorite, and epidote. The association of $U$ with these minerals is consistent with the observation that uranium contents of SSGF shale samples are in the range 4-5 ppm whereas that of the sandstones is only 1-2 ppm, independent of the temperatures over a range of 100 to $350 \mathrm{C}$. After completion of laboratory mineralogical, petrological, and geochemical studies on existing and newly acquired core and brine, the next stage will be to apply the data and concepts derived to problems of nuclear 
waste isolation. The stability of clay minerals as a function of temperature and brine composition will be evaluated. The resulting information on the migration and retardation of naturally occurring radioactive and radiogenic elements in hot brines moving through clay-rich rocks will be used for validation of geochemical models and computer codes. These models will have applications to design of waste packages, backfill materials, and assessments of the expected performance of engineered barrier systems and host rocks under anticipated near field conditions for nuclear waste repositories excavated in salt beds and domes. 


\section{INTRODUCTION}

\subsection{WASTE ISOLATION IN SALT}

\subsubsection{Rock Salt}

During the last 30 years, discussions of safe, environmentally acceptable means of isolating military and civilian radioactive wastes have produced regulations in the U.S.A. favoring development of deep, mined geologic repositories (IRG NWM, 1979; Carter, 1983). The concept is that rocks in appropriate geologic environments and the engineered barrier system should retard release of radionuclides during the many thousands of years during which containment is necessary (EPA, 1981; NRC, 1983). The engineered barrier system includes a waste package of multiple barriers containing components such as canisters, buffers, overpacks, and backfill materials ( $K$ lingsberg and Duguid, 1982).

Among the candidate rock types for geologic repositories, one of the most studied is rock salt, which occurs either as stratified deposits or as salt diapirs (Gonzales, 1981). The intrinsic features which make rock salt attractive as a medium for nuclear waste isolation are its high thermal conductivity, extremely low permeability, ease of mining, low water content, and high plasticity which favors healing of incipient fractures. Rock salt occurrences are widespread in the U.S.A. (Johnson and Gonzales, 1978). However, salt presents the obvious problem of high solubility in water. Ancient beds or domes of rock salt which are free of dissolution phenonema and which are isolated from ground-water intrusions must be identified.

Pure salt also suffers from the disadvantage of having poor sorptive qualities relative to other rock types (Moody, 1982, Table 11). Using bentonite or clay-rich media as backfill around waste canisters or as repository room backfills is one option to improve the sorptive properties of the engineered barrier system. An additional problem is that most salt deposits contains small amounts (usually <1 percent) of highly concentrated brines (Roedder and Basset, 1981) which occur as fluid inclusions in the salt. Because of the increase in solubility of salt with increasing temperature, if gas phases are absent, fluid inclusions in salt tend to migrate toward a heat 
source such as would be generated by a radioactive waste canister (Jenks, 1979). An additional function of using impermeable backfill materials such as clays could be to inhibit access of corrosive brines to the metal canisters.

\subsubsection{Expected Repository Conditions}

The exact conditions anticipated within and around a waste repository excavated in rock salt depend upon the nature of the waste form, the age of its radioactive components, the design and loading history of the repository, the geologic setting, and the specific location with respect to the waste. A distinction is made between near-field and far-field effects. The near field is defined as that rock volume in which the dominant processes are caused by the construction of the geologic repository and the presence of the waste. The far field is the repository host rock unaffected by the heat and radiation of emplaced waste. In this report only near field effects will be considered.

Considerable effort has been directed in recent years to developing conceptual designs of waste repositories in rock salt and estimating the expected environments within them. For example, Claiborne et al (1980) reported an extensive modelling study of the expected temperature conditions in mined repositories in rock salt. They assumed that the waste would be 10 years old at the time of emplacement. High-level waste (HLW) would then generate $2.6 \mathrm{~kW}$ per canister, whereas spent-fuel waste (SF) would generate $0.55 \mathrm{~kW}$ per canister. Depending on the spacing of the canisters, HLW would generate about 12 to $37 \mathrm{~W} / \mathrm{m}^{2}$ and $S F 10$ to $15 \mathrm{~W} / \mathrm{m}^{2}$ of initial thermal load, averaged over the excavated rooms and pillars in the repository (Figure 2-1). This thermal load is greater than the worldwide average natural heat flow in the earth's crust of approximately $0.065 \mathrm{~W} / \mathrm{m}^{2}$ or typical values in intense geothermal areas of $\left\langle 2 \mathrm{~W} / \mathrm{m}^{2}\right.$. The waste emplacement thermal load, therefore, represents a significant perturbation of the ambient temperature field. With the highest thermal load modelled, Claiborne et al (1980) calculated that the maximum temperatures at the canister surface could be as high as $308 \mathrm{C}$, and at the waste centerline $354 \mathrm{C}$ (Table 2-1). However, according to this model, the maximum temperature in the near field in rock salt would only be $211 \mathrm{C}$. and this would occur 15 years after emplacement, after which the temperatures would decline. Different scenarios would lead to different thermal histories; 


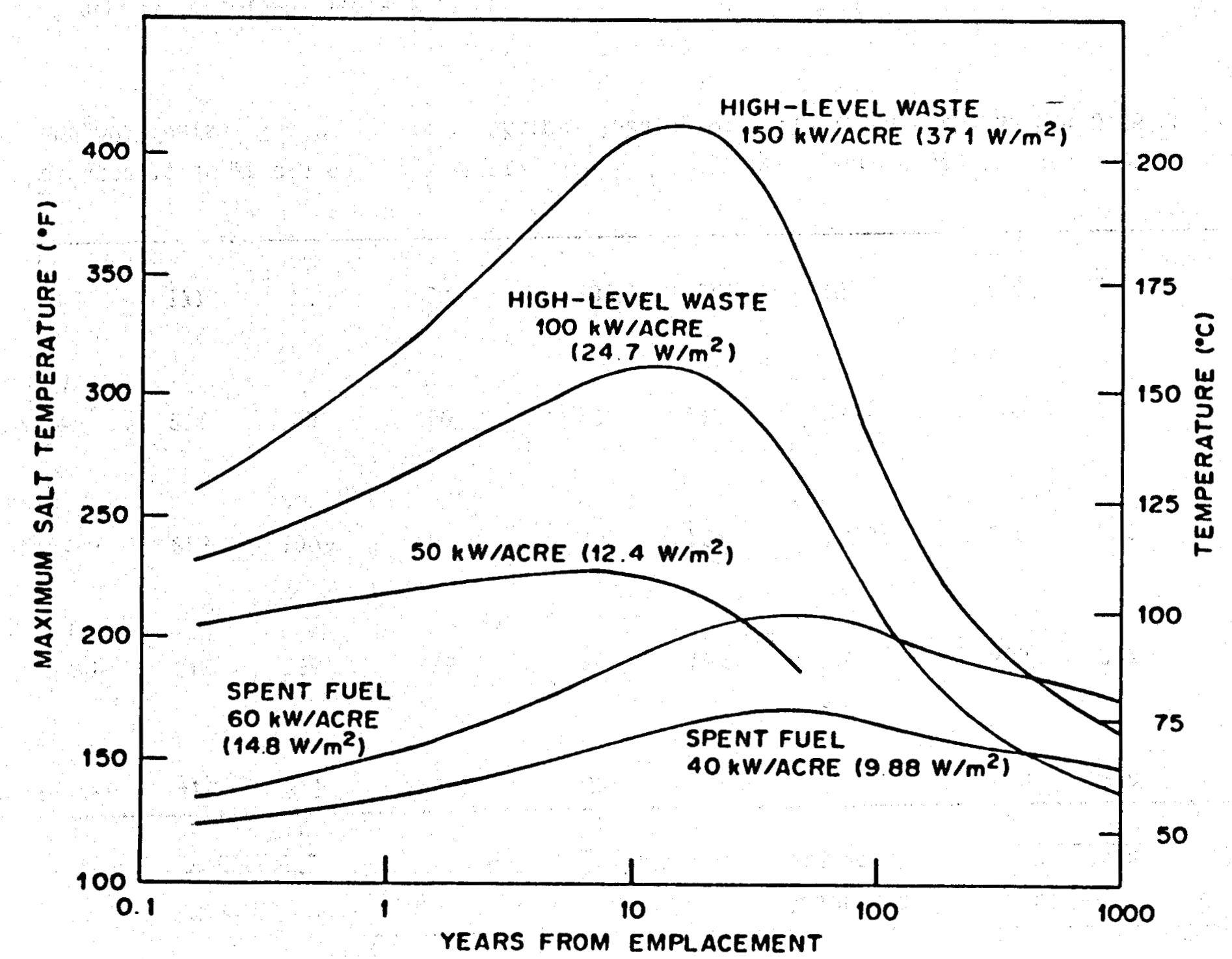

Figure 2-1. Maximum Rock Salt Temperatures Based on Different Initial Thermal Loads in Model Radioactive Waste Repositories in Rock Salt.

(Source - Claiborne et al, 1980, Fig. 5). 
Table 2-1. Maximum Temperatures* in the Rock Salt, Canister Surface, and Waste Centerline way

\begin{tabular}{|c|c|c|c|c|c|c|c|c|c|}
\hline & \multicolumn{3}{|c|}{ Salt } & \multicolumn{3}{|c|}{ Canister surface } & \multicolumn{3}{|c|}{$\begin{array}{l}\text { Waste centerline } \\
\text { (or center pin) }\end{array}$} \\
\hline & \multicolumn{2}{|c|}{$\begin{array}{l}\text { Maximum } \\
\text { temperature } \\
\end{array}$} & \multirow[t]{2}{*}{$\begin{array}{l}\text { Years after } \\
\text { emplacement }\end{array}$} & \multicolumn{2}{|c|}{$\begin{array}{l}\text { Maximum } \\
\text { temperature } \\
\end{array}$} & \multirow[t]{2}{*}{$\begin{array}{l}\text { Years after } \\
\text { emplacement }\end{array}$} & \multicolumn{2}{|c|}{$\begin{array}{l}\text { Maximum } \\
\text { temperature } \\
\end{array}$} & \multirow[t]{2}{*}{$\begin{array}{l}\text { Years after } \\
\text { emplacement }\end{array}$} \\
\hline & ${ }^{\circ} \mathrm{F}$ & ${ }^{\circ} \mathrm{C}$ & & ${ }^{\circ} \mathrm{F}$ & ${ }^{\circ} \mathrm{C}$ & & ${ }^{\circ} \mathrm{F}$ & ${ }^{\circ} \mathrm{C}$ & \\
\hline $\begin{array}{c}H L W, 150 \mathrm{~kW} / \text { acre } \\
\left(37.1 \mathrm{~W} / \mathrm{m}^{2}\right)\end{array}$ & 412 & 211 & 15 & 587 & 308 & 10 & 670 & 354 & 3 \\
\hline $\begin{array}{c}\mathrm{HLW}, 100 \mathrm{~kW} / \mathrm{acre} \\
\left(24.7 \mathrm{~W} / \mathrm{m}^{2}\right)\end{array}$ & 312 & 156 & 15 & 508 & 264 & 3 & 603 & 317 & 1.5 \\
\hline $\begin{array}{c}\mathrm{HLW}, 50 \mathrm{~kW} / \mathrm{acre} \\
\left(12.4 \mathrm{~kW} / \mathrm{m}^{2}\right)\end{array}$ & 228 & 109 & 5 & 459 & 237 & 0.67 & 580 & 304 & 0.5 \\
\hline $\begin{array}{c}\text { SF, } 60 \mathrm{~kW} / \text { acre } \\
\left(14.8 \mathrm{~W} / \mathrm{m}^{2}\right)\end{array}$ & 211 & 99 & 50 & 237 & 113 & 25 & 280 & 138 & $\sim 5$ \\
\hline $\begin{array}{c}\text { SF, } 40 \mathrm{~kW} / \mathrm{acre} \\
\left(9.88 \mathrm{~W} / \mathrm{m}^{2}\right) \\
\end{array}$ & 171 & 77 & 50 & 202 & 94 & 15 & 270 & 132 & $\sim 3$ \\
\hline
\end{tabular}

*Assumes the waste is $10 \mathrm{yr}$ old on emplacement. The HLW decay rates were based on fuel that is a $3: 1 \mathrm{mix}$ of fresh $\mathrm{UO}_{2}$ and MOX fuels. The HLW canister thermal loading was $2.16 \mathrm{~kW}$, and the SF was $0.55 \mathrm{~kW}$ (one PWR fuel element).

Source - Claiborne et al, 1980, Table S-1. 
e.g., the lower the initial thermal loading chosen, the larger the volume of repository necessary to contain a given mass of waste. Thus a trade-off between favorable conditions and favorable costs can be expected.

Quantitative estimates of the amount of residual brine which could enter the holes drilled for canister emplacement depend upon the initial concentration of brine in the salt and upon the calculated thermal history. From the Claiborne et al (1980) model, in a mined repository at $610 \mathrm{~m}$ depth, with emplacement holes in its floor $5.5 \mathrm{~m}$ deep and $0.25 \mathrm{~m}$ in diameter, the maximum total brine inflow over the first 100 years after emplacement would be a minimum of 6 liters for each canister hole.

The expected chemical environment of canisters emplaced in rock salt is important both to modelling the integrity and survivability of the waste form and to discussions of the possible use of materials as backfill. Three types of brine might be involved: brine inclusions, reacted brine in the emplacement hole, and intrusions of brine resulting from mine flooding. Two extremes for brine compositions are shown in Table 2-2 (from Claiborne et al, 1980). Brine $A$ is based on analyses of several brines from the McNutt potash bearing region of the Salado formation. Brine $B$ represents a saturated brine which might be produced in a flooded mine, based on dissolving a core from 830 $m$ depth in the WIPP site near Carlsbad, New Mexico (Claiborne et al, 1980).

\subsubsection{Duration of Isolation}

The intense radioactivity of fission products for several hundred years and the persistence of activities for many thousands of years require isolation of high-level radioactive waste products from the biosphere for very long times in order to permit radioactivity to decay to safe levels.

$\mathrm{Kl}$ ingsberg and Duguid $(1980,1982)$ pose the question, "How long is long enough?" and suggest that an appropriate answer is the time necessary for the radiation produced by the waste to decay to a level equivalent to that produced by natural uranium ores (Figure 2-2). During the first 1,000 years fission products are the main source of radiation; later the actinides and their daughter products are the main contributors. In 500 years high-level wastes decay to a level of radiation equivalent to a uranium ore body. Spent 
Table 2-2. Compositions of Waste Isolation Pilot Plant Brines $A$ and $B$

\begin{tabular}{|c|c|c|}
\hline \multirow[t]{2}{*}{ Ion } & \multicolumn{2}{|c|}{ Concentration $[(\mathrm{mg} / \mathrm{l}) \pm 3 \%)$} \\
\hline & Brine A & Brine B \\
\hline $\mathrm{Na}^{+}$ & 42,000 & 115,000 \\
\hline $\mathrm{K}^{+}$ & 30,000 & 15 \\
\hline $\mathrm{Mg}^{2+}$ & 35,000 & 10 \\
\hline $\mathrm{Ca}^{2+}$ & 600 & 900 \\
\hline $\mathrm{Fe}^{3+}$ & 2 & 2 \\
\hline $\mathrm{Sr}^{2+}$ & 5 & 15 \\
\hline $\mathrm{Li}^{+}$ & 20 & \\
\hline $\mathrm{Rb}^{+}$ & 20 & 1 \\
\hline $\mathrm{Cs}^{+}$ & 1 & 1 \\
\hline $\mathrm{Cl}^{-}$ & 190,000 & 175,000 \\
\hline $\mathrm{SO}_{4}^{-2}$ & 3,500 & 3,500 \\
\hline $\mathrm{BO}_{3}^{3-}$ & 1,200 & 10 \\
\hline $\mathrm{HCO}_{3}^{-}$ & 700 & 10 \\
\hline \multicolumn{3}{|l|}{$\mathrm{NO}_{3}^{-}$} \\
\hline $\mathrm{Br}^{-}$ & 400 & 400 \\
\hline $\mathrm{I}^{-}$ & 10 & 10 \\
\hline pH (adjusted) & 6.5 & 6.5 \\
\hline Specific gravity & 1.2 & 1.2 \\
\hline
\end{tabular}

Possible brine compositions in a waste repository in salt. Brine $A$ is based on analyses of several brines from potash-bearing salt formations. Brine $B$ represents a possible brine produced by solution of salts in the WIPP site near Carlsbad, New Mexico (Source - Table 10, Claiborne et al, 1980). 


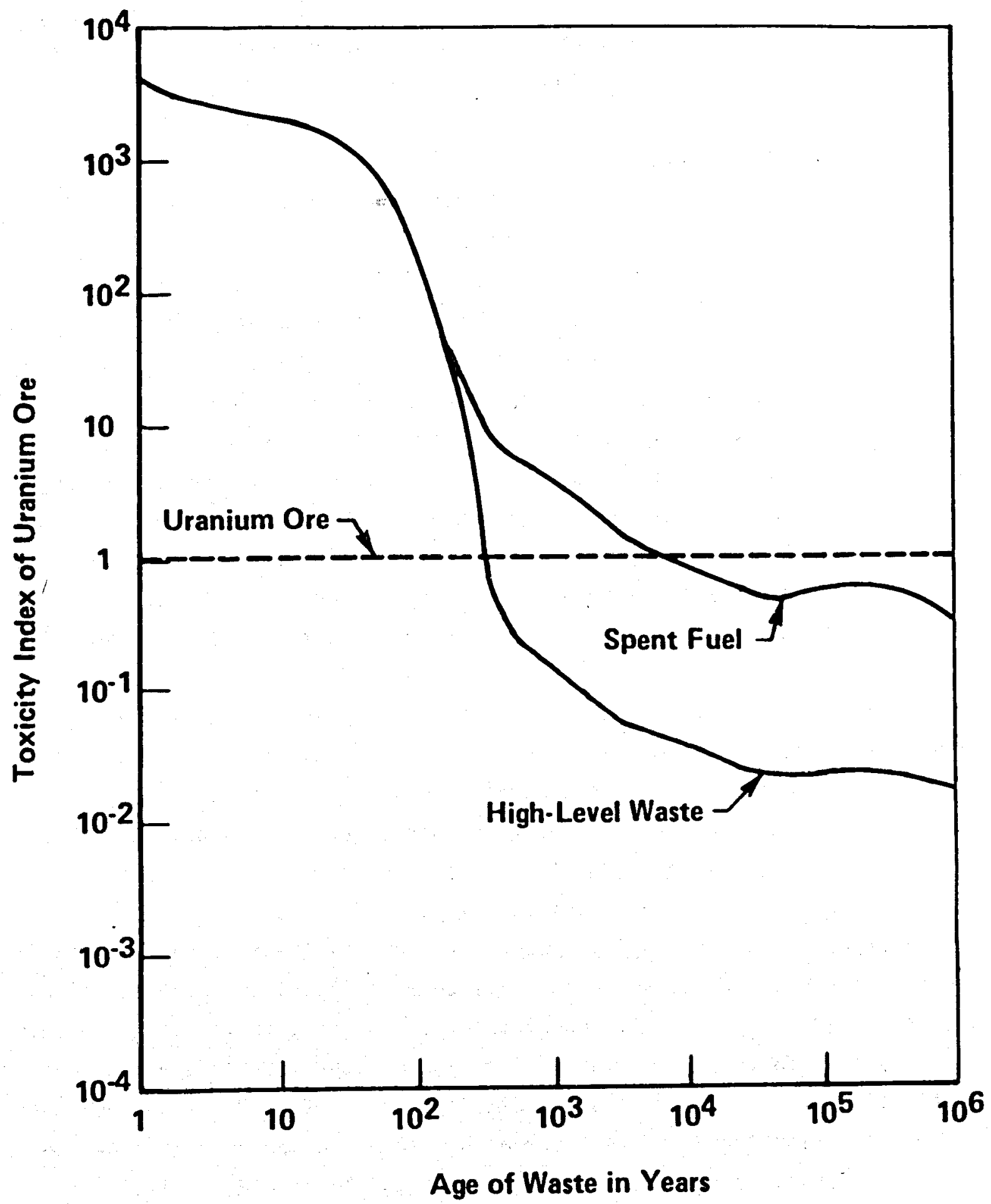

Figure 2-2. Relative Toxicity of Equivalent Amounts of Uranium Ore, Spent Fuel, and High-level Waste.

"Equivalent amounts" means (1) the quantity of ore containing $0.2 \%$ uranium required to produce one metric ton of reactor fuel, (2) one metric ton of spent fuel, and (3) the amount of HLW produced from reprocessing one metric ton of spent fuel (Source - Klingsberg and Duguid, 1980, Fig. 2). 
fuel, which has not been reprocessed, requires about 7,000 years to reach this level (Klingsberg and Duguid, 1980).

\subsection{NATURAL ANALOG STUDIES}

\subsubsection{Purpose}

The problem of modelling and predicting the probable migration of radionuclides deeply buried in a geologic repository over thousands of years is unprecedented. The need to understand the long-term behavior of the waste package can only be partly satisfied by short-term experiments. Uncertainties remain in extrapolating laboratory results to a geologic repository where processes are not only of much longer duration, but likely more complex. The need to understand the long-term effects of even low rates of heat and mass transfer and the effects of water/rock reactions on the integrity of the geologic system is fundamental to predicting the performance of waste repositories.

Al though these efforts must rely to a great degree upon mathematical modelling, regulations for licensing geologic repositories require validation of computer codes. Validation of these codes requires that results of mathematical modelling be compared with appropriate laboratory and field measurements. Studies of natural analogs must therefore be used for processes with durations longer than is possible in the laboratory.

Fortunately the geological record provides examples of natural long-lived laboratories where processes comparable to a radioactive waste isolation have occurred. Probably the most apt example of a natural analog is the uranium ore body at 0k10 in Gabon, West Africa, which naturally achieved nuclear criticality over a period of about $2 \times 10^{5}$ years about 1800 million years ago. The radionuclides produced were comparable to those produced in man-made reactors. Study of this occurrence support, at least qualitatively, the concept of the general effectiveness of geologic barriers to the transport of long-lived radionuclides (Cowan, 1976).

Other natural analogs which might be considered include metamorphic haloes around igneous intrusions to provide data on the effect of heat on clay backfill materials, the metamict effect in minerals to provide information on 
potential damage to ceramic materials by radioactivity, and the effects of long-term heat transfer on aquifers in active geothermal systems (Tammemagi et al, 1983).

Studies of active geothermal fields offer a number of advantages in this regard. Direct measurements of the temperature field can be made and samples of rock and brine obtained. Similarly, direct measurements of permeability and porosity can be made and inferences derived on natural rates of heat and mass transfer over the lifetime of the field. Unfortunately, an example of a well-explored geothermal field developed in bedded or domal rock salt is lacking. Efficient heat transfer also requires convecting ground water, which is adverse to the survival of salt.

\subsubsection{Choice of the Salton Sea Field}

The SSGF in the Imperial Valley of southern California was chosen for this study of a near-field analog because:

(1) the SSGF is a geologically well-defined geothermal area;

(2) the SSGF is undergoing commercial development, so that drill cores, cuttings and water samples can be obtained from it;

(3) the SSGF has measured temperatures bracketing the range expected in a waste repository;

(4) deep groundwater salinities cover the total range expected in a salt repository; and

(5) although salt is absent, the sedimentary stratigraphic sequence is otherwise similar to that found in bedded or domal salt areas. The aims of the study are to investigate (1) the geologic conditions under which rock/water interactions mobilize elements such as $U$, Th, Ra, Cs, and $\mathrm{Sr}$; and (2) if mobilized, how far they are transported before being removed from the brine by chemical processes. The mineral stabilities, especially of clays, will also be studied for their durability as a function of temperature, depth and salinity. We expect that the results of this study will be used as input for waste package design and performance assessments of the engineered barrier system and host rock under the conditions of a salt repository, and will be used quantitatively for geochemical model validation. 


\section{GEOTHERMAL SYSTEMS OF THE SALTON TROUGH}

\subsection{REGIONAL SETTING}

The Salton Sea Geothermal Field (SSGF) is one of a number of highintensity geothermal fields which occur in a structural depression, known as the Salton Trough, at the head of the Gulf of California in northern Baja California, Mexico, and southern California, U.S.A. (Figure 3-1). This depression forms part of the boundary between the North American and Pacific plates. This region marks the transition between the purely extensional tectonics of the East Pacific Rise to the south, at the mouth of the Gulf, and the transform fault tectonics of the San Andreas Fault system, to the north. The SSGF thus represents one of the few places in the world where an extensional plate boundary is affecting continental crust (Elders et al, 1972; Elders and Biehler, 1975). The Salton Trough is a sediment-filled rift valley that represents the landward extension of the Gulf of California into North America. The high heat flow of this tectonic setting is the ultimate origin of the geothermal resources of the Salton Trough. This association has recently been described by Elders (1979); much of the following regional discussion is based on that publication.

\subsection{STRATIGRAPHY AND SEDIMENTATION}

The present apex of the Colorado River delta forms a low divide (11 m above sea level at its lowest point) between the Imperial valley to the north and the Mexicali Valley to the south (Figure 3-1). Most of the Imperial Valley lies below sea level. At its northern end is the Salton Sea, which covers about $930 \mathrm{~km}^{2}$ and has a surface elevation of about $70 \mathrm{~m}$ below sea level. Water entering the Imperial Valley can only escape by evaporation. The Colorado River enters the Salton Trough from the east at Yuma, $43 \mathrm{~m}$ above sea level. The delta slopes northward (at $\sim 0.8 \mathrm{~m} / \mathrm{km}$ ) into the Salton Basin and southward (at $\sim 0.35 \mathrm{~m} / \mathrm{km}$ ) to the Gulf of California. During 1905 to 1907 , the Colorado River flooded over the delta crest into the Salton Basin, forming the Salton Sea (Sykes, 1937). Although the discharge of the River is now into the Gulf of California, inflow of Colorado River water via irrigation canals causes the Salton Sea to persist today. 


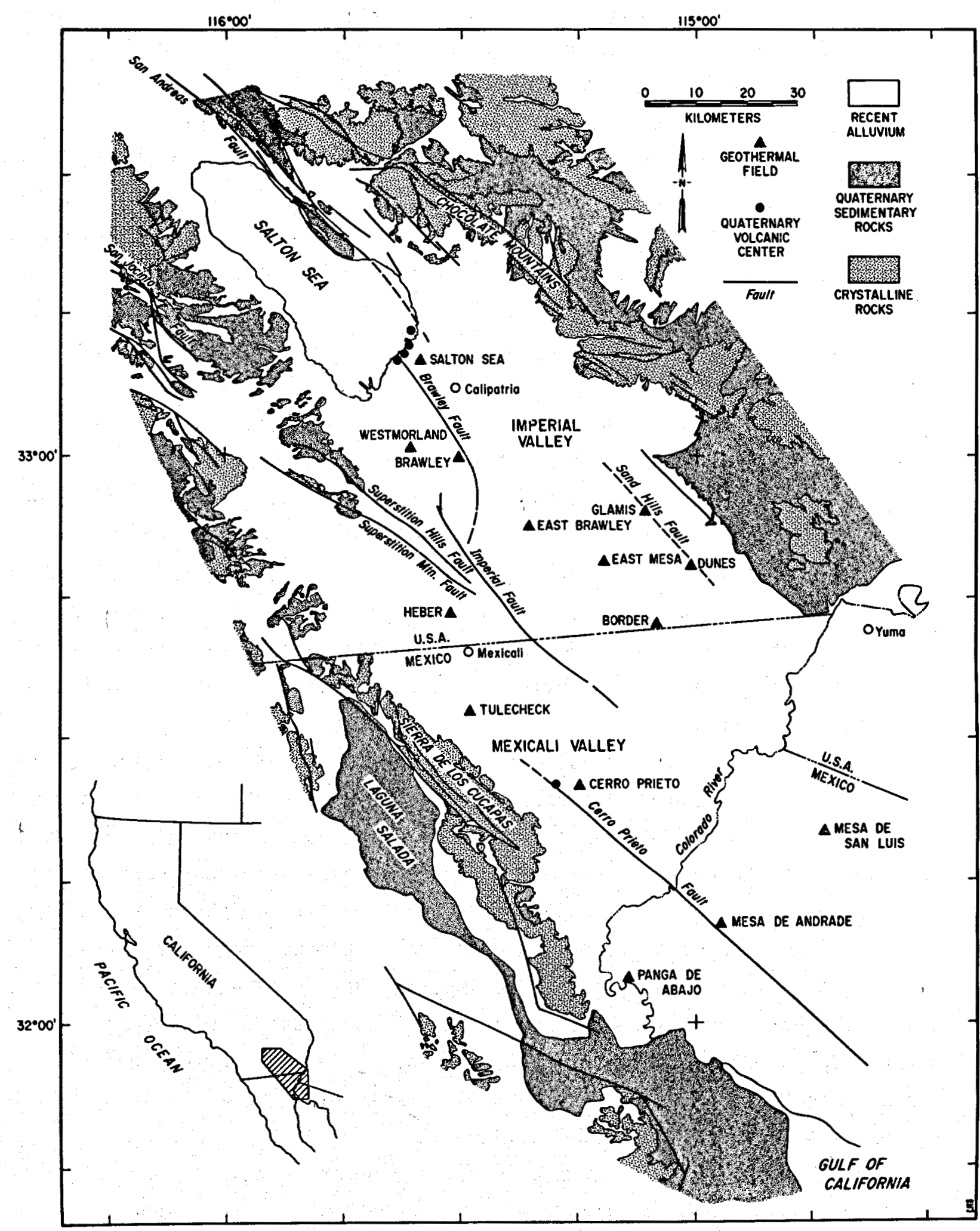

Figure 3-1. Geothermal Fields of the Salton Trough. 
The Salton Trough is an actively growing rift valley in which sedimentation has almost kept pace with tectonism. Formation of the delta perpendicular to the length of the Gulf of California rift has isolated the Salton Basin from the Gulf, forming a closed sedimentary basin $200 \mathrm{~km}$ long and up to $90 \mathrm{~km}$ wide. When the river flowed to the Gulf, it graded its bed to sea level and therefore formed a steeper gradient to the north to the closed basin. In times of flood, when the river topped its levees, any distributaries which flowed north could capture the flow. Then the basin filled until it spilled over the low point of the crust of the delta. The river then graded its bed to the elevation of the lake it had created, $11 \mathrm{~m}$ above sea level. At this point the gradient to south to the sea would be steeper than that to the north so that, in times of flood when the river topped its levees, the distributaries which flowed south captured the flow. Thus the delta oscillated between two metastable conditions with the river flowing alternately to the north and south. The history of the Salton Basin during the last few million years has thus been cycles of filling with freshwater lakes followed by desiccation. Although sediments from the walls of the Basin form marginal alluvial fans, the Colorado River has dominated the sedimentary history.

The deltaic deposits consist of interbedded, poorly fossiliferous sand, silts, clays, and pebble conglomerates (Van De Kamp, 1973) with the percentage of sand bodies in the sediments decreasing away from the delta apex towards the northwest (Randall, 1974). The delta sediments are interspersed with lacustrine and reworked eolian deposits. Rather little is known, however, of the nature and age of the sedimentary rocks in the central part of the Basin. The deepest wells yet drilled in the Imperial Valley penetrate $3-4 \mathrm{~km}$ but there have not been any published reports of their paleontology and stratigraphy. At Cerro Prieto, however, Ingle (1981) reported that the Pleistocene-Pliocene boundary occurs at a depth of 2,000 $\mathrm{m}$, based upon micropaleontological study of drill cuttings.

The stratigraphy of the Neogene rocks cropping out in structurally complex zones on both sides of the Imperial Valley has been summarized by Dibblee (1954) and by Sharp (1982). Included in these formations at the sides of the basin are a few marine units, the oldest of which may be as old as Miocene. Maximum marine submergence occurred during the Pliocene, and 
intermittent shallow marine environments persisted in the western part of the Imperial Valley until middle Pleistocene (Woodard, 1974). Such marine rocks have not yet been reliably reported from any of the numerous drill holes in the main part of the valley, even in the deepest, which is the Wilson No. 1 $(4097 \mathrm{~m}), 10 \mathrm{~km}$ southeast of Brawley.

In this deltaic environment correlation of stratigraphic units in the subsurface becomes particularly difficult. Even at outcrop, correlations are not easy because of abrupt lateral facies changes (Wagoner, 1977). The stratigraphic sections shown in figure $3-2$ record the changing conditions in the basin.

The Miocene sedimentary rocks of the Anza Formation, in the southwestern Imperial Valley, are fan deposits and conglomerates which record early nonmarine deposition in a closed basin. The Middle to Late Miocene Split Mountain and Mecca Formations, and the Pliocene Imperial Formation are arenites and mudstones which together record a major marine incursion into the basin in late Miocene to early Pliocene time. The upper part of these formations record a gradual change to a continental provenance. This marine embayment apparently stretched into the area of Yuma and along the valleys of the Colorado and Gila Rivers; as the marine Bouse Formation of Arizona is apparently partily correlative with the Imperial Formation and is approximately 5 MY old (01msted et al, 1973). The marine embayment also stretched as far north as Whitewater in the Coachella Valley; the Salton Trough thus was already well defined at that time. The oldest Tertiary sedimentary units in the region rest on crystalline rocks, high above the basin in the mountains on its western side. These sedimentary rocks are the Jacumba Gravels which are older than 19 MY.

Lucchitta (1972) discussed the early history of the Colorado River in the Basin and Range Province and suggested that a large river, an ancestral Colorado, entered the Bouse marine embayment from the north, progressively filled it and reached the Salton Trough. This river did not exist before 10.6 MY ago. Late Cretaceous foraminifera, apparently derived from the Mancos Shale of the Colorado $\mathrm{Plateau}$, have been reported from the Imperial and younger formations (Lucchitta, 1972), indicating that the ancestral river was bringing sediment to a Salton basin occupied by sea water at that time. As the delta continued to fill the trough, conditions gradually changed from 


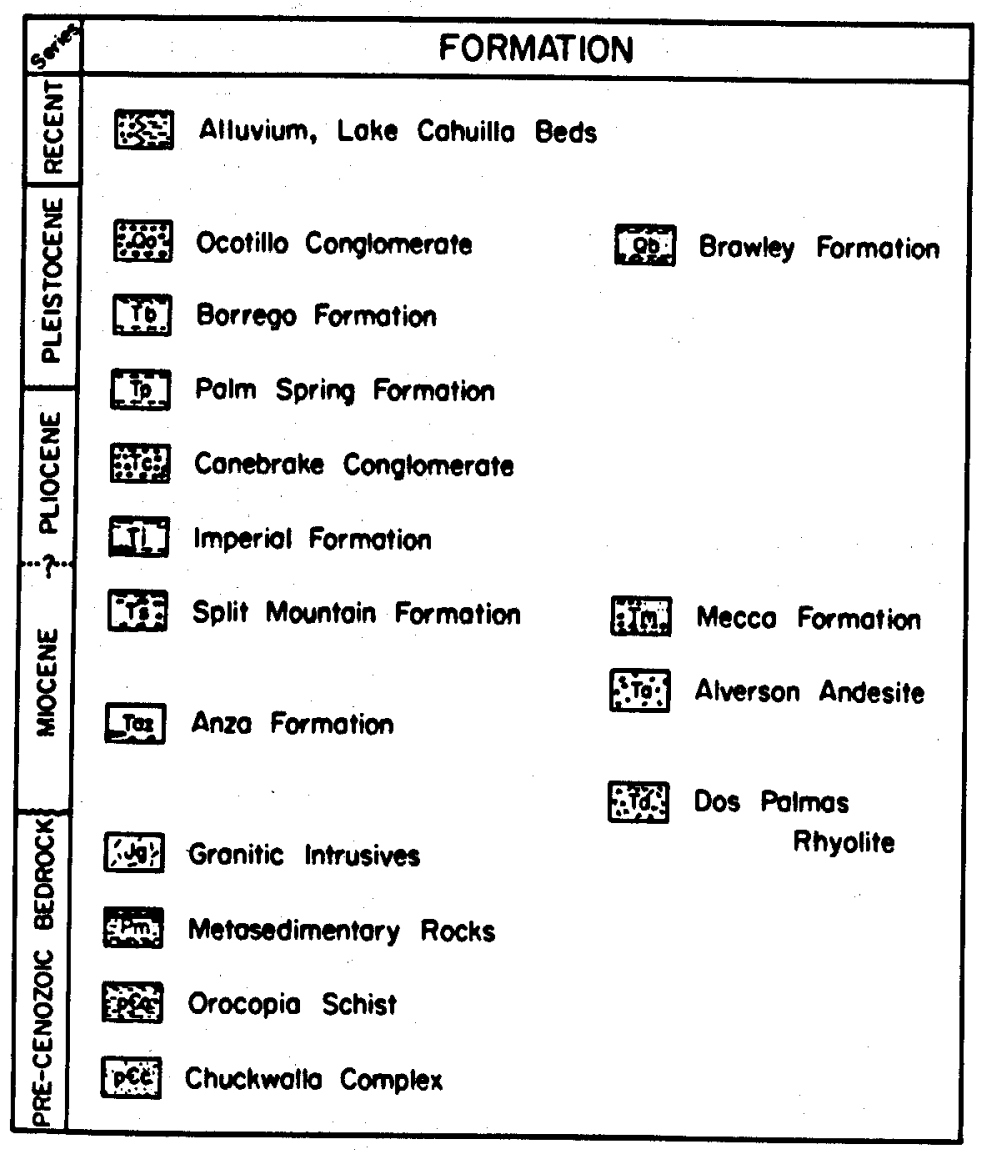

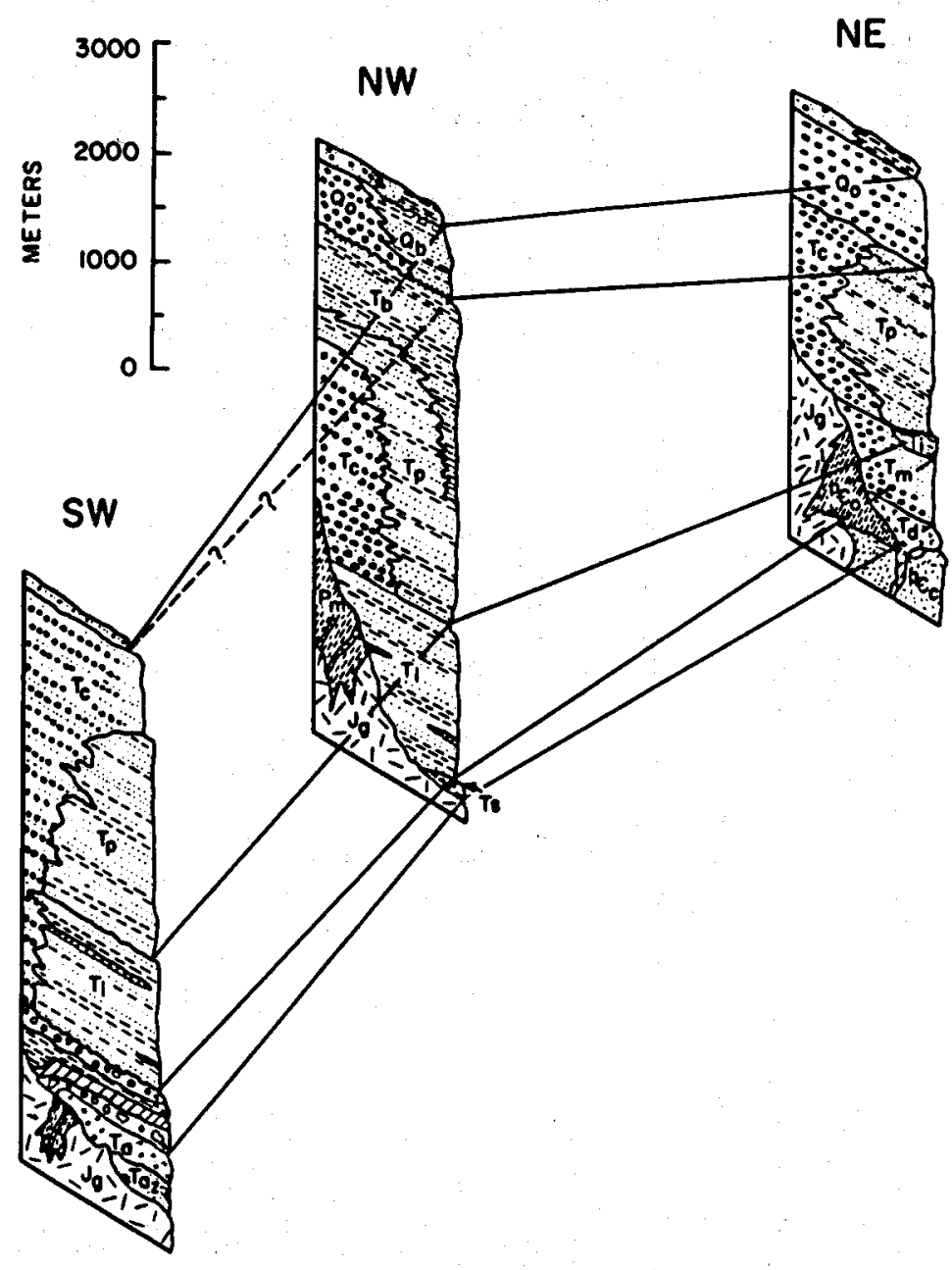

Figure 3-2. Regional Stratigraphy of the Imperial Valley.

The fence diagrams represent the true relative thicknesses of the sedimentary formations and display the regional thickness changes and facies changes of the units. The sections represent the southwestern, northwestern, and northeastern Imperial Valley. The horizontal scale is schematic. Adapted from Dibblee (1954) and Woodward (1974) (Source - Wagoner, 1977, Fig. 3). 
marine, to deltaic, to subaerial. A well developed Colorado River existed by 3.3 MY (Lucchitta, 1972). Since that time deposition has apparently kept pace with subsidence of the basin.

The Canebrake Conglomerate represents a coarse basin-margin facies of the Imperial and Palm Springs Formations (Figure 3-2) and occurs mainly along the west side of the basin. The Palm Springs Formation is a fluvial and deltaic deposit formed throughout the basin, whereas the Borrego and Brawley Formations represent the lacustrine sedimentation with intermittent marine incurions which was dominant in the basin during the Pleistocene. The ocotillo Conglomerate is the western terrestrial basin-margin facies of the Brawley Formation. Finally, the Lake Cahuilla beds represent the most recent in a series of Holocene fresh to brackish water lakes which have occupied the closed Salton Basin as the river flowed north.

\subsection{SEISMICITY AND STRUCTURE OF THE SALTON TROUGH}

In location, gross structure, and size the Salton Trough belongs to the Gulf of California tectonic regime. In both the Gulf and the Salton Trough, rapid tectonic deformation and patterns of high heat flow, seismicity, sedimentation, and Quaternary volcanism reflect the transition from a divergent to a transform plate boundary. The Salton Trough and Gulf of California are both dominated at present by "leaky" transform faulting, with tensional zones developed at the ends of right-stepping en echelon strike-slip faults (Elders and Biehler, 1975).

The Salton Trough is a roughly triangular basin some $350 \mathrm{~km}$ long and 120 $\mathrm{km}$ wide at its southern end. This complex rift valley is bordered by mountains consisting of Mesozoic and older granitic and metamorphic rocks, with some Tertiary volcanic rocks. The Trough has steep, step-faulted margins and a broad, relatively flat basement floor beneath a cover of sedimentary rocks apparently 6 to $10 \mathrm{~km}$ thick in the center of the Imperial Valley (Biehler et al, 1964; Elders et al, 1972; Fuis et al, 1982). These rocks are transected by three major fault systems which trend northwest-southeast: the San Andreas, San Jacinto, and Elsinore fault zones (Figure 3-1). Numerous subsidiary blocks and basins are aligned along these major strike-slip faults. 
Seismic activity on these faults makes the Salton Trough one of the most earthquake-prone areas in North America. There have been 12 earthquakes of modified Mercalli intensity greater than VIII in the region this century. The area is characterized by two distinct types of seismicity, i.e., by mainshock/aftershock sequences producing right-lateral strike-slip faulting, and by frequent earthquake swarms in which as many as a thousand events may occur in a few days (Johnson and Hill, 1982).

An example of a major earthquake associated with right-lateral faulting and aftershock sequences occurred on October 15, 1979. This mainshock event had a moment-magnitude (M) of 6.5 with an epicenter located $3 \mathrm{~km}$ south of the international border, approximately $10 \mathrm{~km}$ east of Mexicali, Mexico (USGS, 1982). All of the surface rupture and most of the damage occurred further north in the region of El Centro and Brawley, along the Imperial fault (Figure 3-3). Most of the aftershocks, one of which had a local magnitude $\left(M_{L}\right)$ of 5.8 , also occurred further north near Brawley. The mainshock produced surface rupture along a $30.5 \mathrm{~km}$ long segment of the Imperial fault with a maximum right-lateral offset of about $60 \mathrm{~cm}$. During the next six months post-seismic slip produced an additional displacement of up to $30 \mathrm{~cm}$ (USGS, 1982).

Earthquake swarms occur along the Brawley fault zone every two or three years (Figure $3-3$ ). The swarms also show predominantly right-lateral strikeslip first motions but a significant number of events have dilatational first motions. In June 1981, one event in a swarm had a magnitude $\left(M_{L}\right)$ of 5.0. These swarms, although discrete in space and time, also exhibit migration of hypocenters during a swarm.

Two different models have been proposed to explain this swarm activity (Johnson and Hill, 1982). In both, fluid is postulated to be the principal rate-controlling agent associated with readjustment of stress. The first model proposes that local spreading between offset strike-slip faults is taken up by emplacement of igneous dikes parallel to the regional principal horizontal stress. Earthquake swarms are generated along planes of shear failure connecting tips of adjacent offset dikes as the fluid pressure approaches the value of the minimum principal horizontal stress in the brittle crust (Johnson and Hill, 1982).

In the second model, the swarms are inferred to be triggered by episodic creep events at depths of 3 to $6 \mathrm{~km}$ which induce redistribution of 


\section{3}

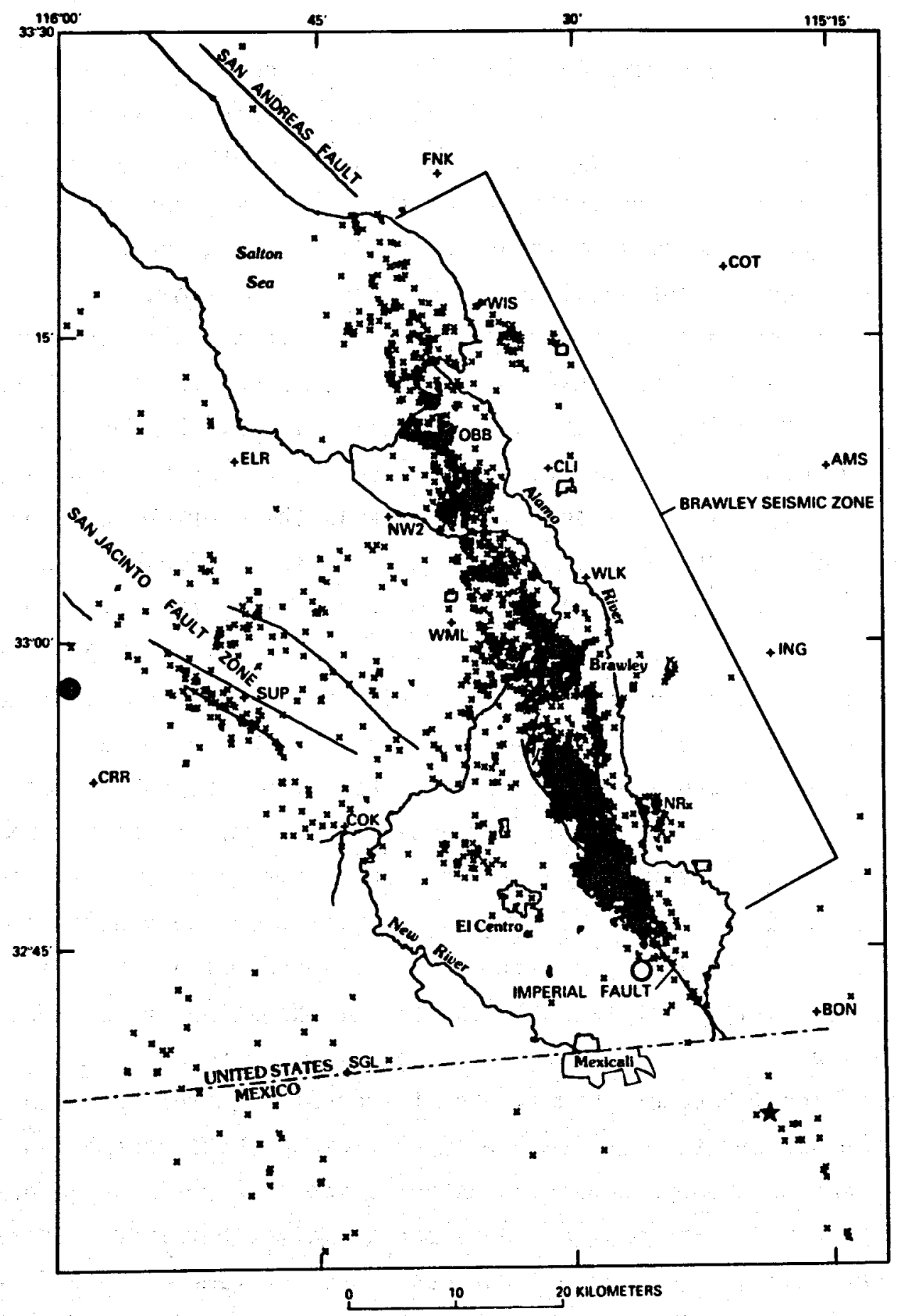

Figure 3-3. Epicenters with Relative Horizontal Location Errors Less than $2.5 \mathrm{~km}$ for Interval June 1973 Through November 1978 Which Included Several Earthquake Swarms.

Circle marks instrumental epicenter of 1940 Imperial Valley earthquake $\left(M_{L}=7.1\right)$, dot for 1942 Superstition Mountain earthquake $\left(M_{L}=6.5\right)$, and star for 1979 Imperial Valley earthquake. Letters refer to station localities in southern California seismic network (Source - USGS, 1982). 
interstitial fluid pressure; this, in turn, induces shear failure (Johnson and $\mathrm{Hill}, 1982)$. The occurrence of earthquake swarms due to changes of fluid pressure, whether caused by magma injection at depth or by episodic fault creep, has important implications for the geothermal reservoirs in the Salton Trough. Changes in fluid pressure cause fluid flow, and brittle deformation generates fracture permeability and enhances fluid flow.

All hypocenters reported from the Salton Trough and northern Gulf of California are shallower than $15 \mathrm{~km}$ and most originate at less than $6 \mathrm{~km}$ (Elders, 1979). Indeed, within the Imperial Valley the focal depths are typically between 4 and $6 \mathrm{~km}$ and none exceed $8 \mathrm{~km}$ depth (Johnson and Hill, 1982). Nearly all of the seismic failure is therefore within the sedimentary section above the basement. Earlier work on surface seismic-wave dispersion suggests that the crust beneath the Imperial valley thins to about $20 \mathrm{~km}$ and that the crust under the northern half of the Gulf may be only $10 \mathrm{~km}$ thick (Thatcher et al, 1971; and Elders and Biehler, 1975). Certainly a large part of the regional gravity anomaly can be explained in this way.

A complete Bouguer anomaly map of the Salton Trough indicates that the earth's crust is isostatically compensated south of the Salton Sea where the valley, although underlain by $6 \mathrm{~km}$ of low-density sediments, is characterized by a broad gravity maximum (Biehler, 1964). Immediately north of the Salton Sea, where the thickness of sediments in the Coachella Valley is less than 3 $\mathrm{km}$, the residual gravity anomaly is markedly negative, reaching a minimum of -44 milligals.

A regional Bouguer anomaly map of southern California based on 28,000 gravity measurements was compiled by averaging Bouguer anomalies within 20-km squares and produced a smoothly contoured map (Figure 3-4) (Elders et al, 1972). Because features like the Imperial Valley have widths considerably in excess of $20 \mathrm{~km}$, this averaging process does not remove the effect of the low-density sêdiments in the southern portion of the Salton Trough. On the basis of basement seismic refraction, borehole, and geological data, Elders et al (1972) constructed a density model of the sediments of the Imperial Valley and estimated their effect on gravity (dashed lines in Figure 3-4). The result is crust-mantle models such as the one shown in figure 3-4.

These models indicate that the crust beneath the axis of the Salton Trough is either (1) about $8 \mathrm{~km}$ thinner (thickness 20 to $22 \mathrm{~km}$ ) or (2) of 
A.
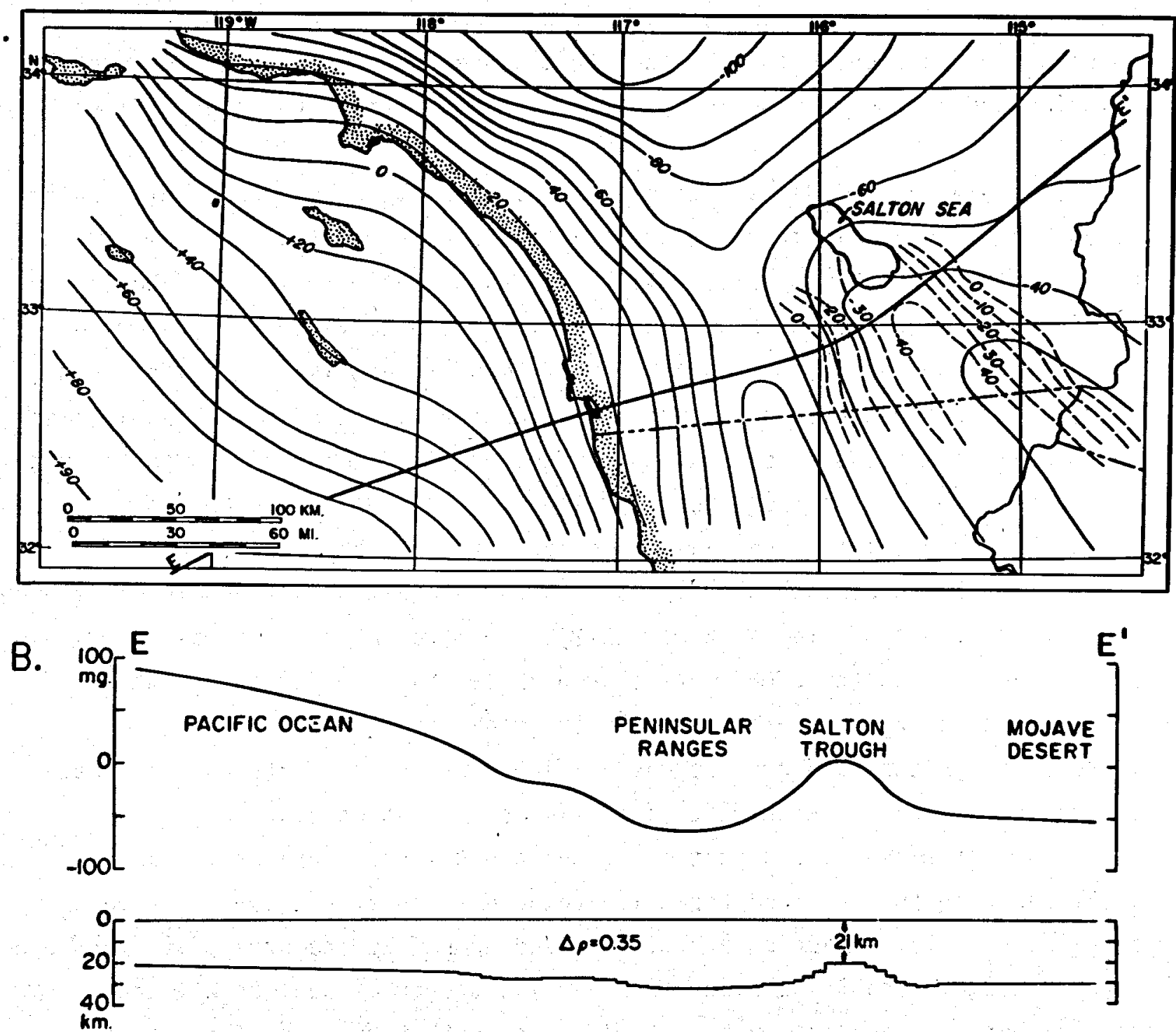

Figure 3-4. (A) Regional Bouguer Gravity Anomalies of Southern California from the Continental Borderland to the Colorado River. (B) One Crust-mantle Model, Computed Along the Line EE' in $(A)$, Showing the Thinner Crust Beneath the Salton Trough.

The solid lines are contours in milligals. The dashed lines, south of the Salton Sea, represent the gravitational effect of low-density sediments in the Imperial Valley (Source - Elders et al, 1972). 
higher density (density excess 0.10 gram per cubic centimeter) than the normal continental thickness and density for the surrounding area. Combinations of these two models will also fit the gravity anomaly. These rapid lateral changes were attributed to processes that cause the crust to undergo ductile thinning and become more oceanic (mafic) in character to the south (Elders et a), 1972).

Savino et al (1977) simultaneously inverted the gravity data of Biehler (1964) and teleseismic travel time data to derive a model of crustal thickness beneath the Imperial Valley and its geothermal fields. The lateral density and velocity contrasts needed to fit the observed data were quite large: greater than $0.3 \mathrm{gm} \mathrm{cm}^{-3}$ and $\sim 0.7 \mathrm{~km} / \mathrm{s}$, respectively. Savino et al (1979) attributed the observed anomalies in gravity and seismic travel times to lateral variations in crustal thickness. Their model requires that crustal thickness both west of the Imperial Valley, in the Peninsular Ranges, and east, in the Chocolate Mountains, is greater than $30 \mathrm{~km}$. The reduction in crustal thickness beneath the Imperial Valley suggested by their model is even greater than that of Elders et al (1972). This reduction is particularly pronounced beneath the SSGF where they propose that crustal thickness is of the order of $10 \mathrm{~km}$. Uncertainties in the model crustal thickness are introduced by localized occurrences of high density sediments and/or igneous intrusions associated with geothermal fields (Savino et al, 1977).

The most recent investigation of the crustal structure of the Imperial Valley is also the most comprehensive to date (Fuis et al, 1982). Five detailed seismic-refraction profiles, based upon 1,300 recording stations and more than 3,000 usable seismograms, reveal a trough of sedimentary and metasedimentary rocks as much as 10-16 $\mathrm{km}$ deep that has a configuration tending to be an exaggeration of the present topography of the Salton Trough. The deepest part of this trough coincides with the zone of highest seismicity in the center of the valley. This central zone of present-ay rifting is bounded to the west by a buried scarp coinciding in places with the mapped Superstition Hills and Superstition Mountain faults, and elsewhere with what the authors interpret as the buried rift that initiated formation of the Salton Trough (Fuis et al, 1982). On the east side of this buried rift, thinning of the sedimentary pile is more gradual, as a buried scarp is not apparent. No refractions from the Moho were observed or expected in the range of distances covered by this survey. 
Inferred variations of seismic velocity with depth are shown in Figure 3-5 (Fuis et al, 1982). In the central part of the valley, near the international border, the velocity increases from $1.8 \mathrm{~km} / \mathrm{s}$ near the surface to $5.05 \mathrm{~km} / \mathrm{s}$ at a depth of $5.8 \mathrm{~km}$. At that depth the increase of velocity with depth becomes much less, so that $5.85 \mathrm{~km} / \mathrm{s}$ is not reached until $13 \mathrm{~km}$ depth. There a sudden jump in seismic velocity to $6.6 \mathrm{~km} / \mathrm{s}$ occurs, which is followed by a rapid increase in gradient, producing an increase to $7.2 \mathrm{~km} / \mathrm{s}$ within only $1 \mathrm{~km}$. Below $14 \mathrm{~km}$ depth the velocity-depth gradient is again small (Figure 3-5). The sudden jump from 5.85 to $6.60 \mathrm{~km} / \mathrm{s}$ occurs at progressively deeper levels to the northwest. This discontinuity occurs at $16 \mathrm{~km}$ depth immediately south of the Salton Sea (Fuis et al, 1982).

This velocity structure is in marked contrast with that observed in the western third of the Imperial Valley (curve labelled "West Mesa" in Figure $3-5)$. Starting with a value of $1.8 \mathrm{~km} / \mathrm{s}$ the velocity gradually increases to $2.4 \mathrm{~km} / \mathrm{s}$ at $1.4 \mathrm{~km}$ depth to the first discontinuity where it jumps to 5.9 $\mathrm{km} / \mathrm{s}$. The seismic velocity then increases at a less steep gradient. The jump in seismic velocity at about $2 \mathrm{~km}$ depth beneath West Mesa is inferred to be the interface between sediment and granitic basement. The velocity of 5.9 $\mathrm{km} / \mathrm{s}$ in this basement is appropriate for crystalline rocks of granitic composition (Fuis et al, 1982).

The nature of "basement" in the center of the valley is quite different. A simple sediment-crystalline rock boundary, which requires a sharp jump in seismic velocity, does not occur. Instead, the sudden decrease in velocitydepth gradient is apparently due to a transition into metasedimentary rocks, with seismic velocity of $5.65 \mathrm{~km} / \mathrm{s}$, that is too low for granitic basement but consistent with velocities in rocks of lower greenschist metamorphic facies (Fuis et al, 1982). In view of the high heat flow and high temperatures observed in deep boreholes, we can anticipate that temperatures exceeding $300 \mathrm{C}$ could be fairly ubiquitous below $5 \mathrm{~km}$ depth in the central part of the Imperial Valley (Elders, 1979).

This metasedimentary "upper basement" persists to a depth of 10 to $16 \mathrm{~km}$ and is underlain by a "lower basement" having seismic velocities exceeding 6.6 $\mathrm{km} / \mathrm{sec}$ and even $7.2 \mathrm{~km} / \mathrm{s}$. Two lines of reasoning suggest that this lower basement consists of mafic intrusive rocks. First, the observed range of seismic velocities is similar to that observed in oceanic crust at depths of 5 


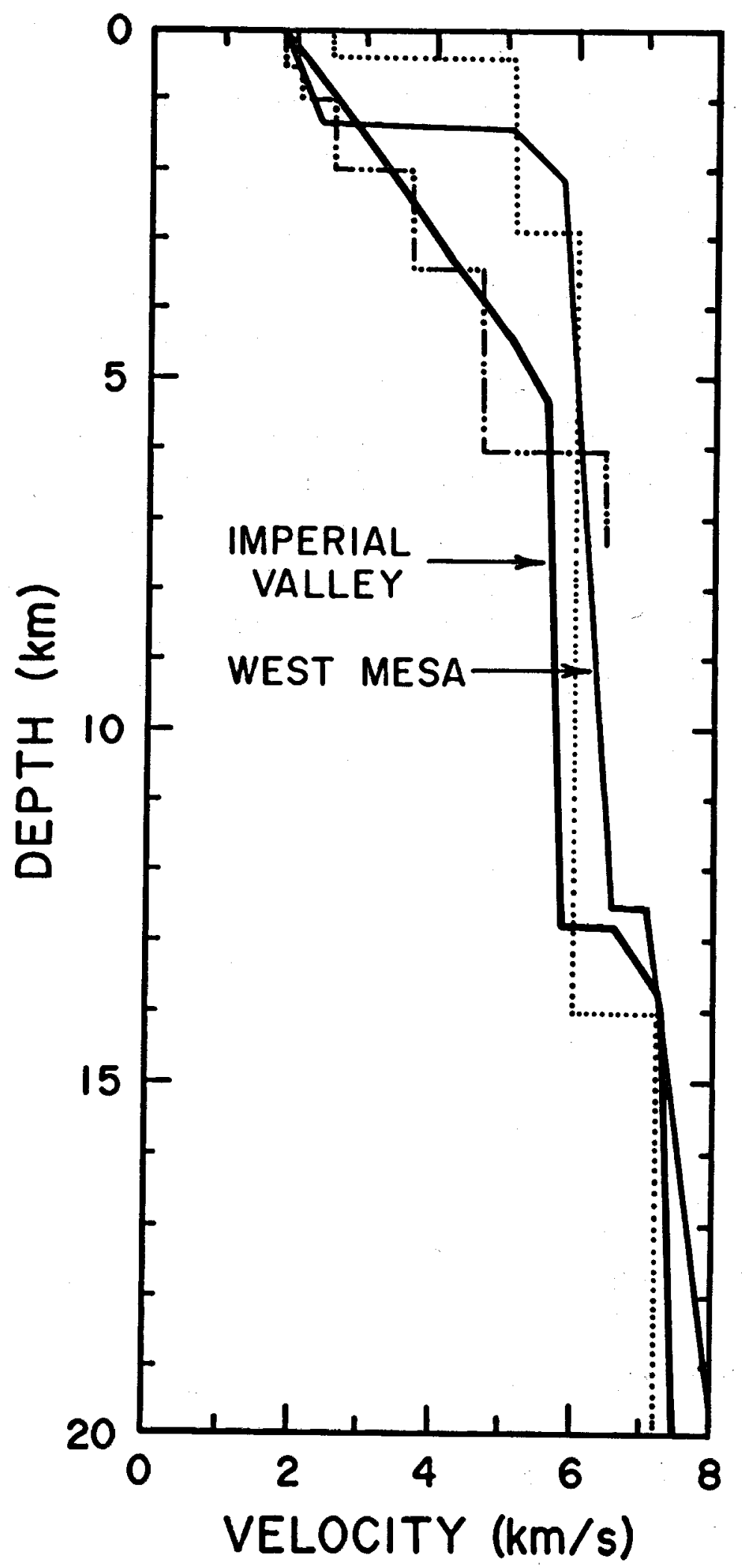

Figure 3-5. Seismic Velocity with Depth in the Salton Trough. Solid lines are from Fuis et al (1982). Their "Imperial Valley" profile is similar to that of Biehler et al (1964) [dot-dash line] for the central Valley; the "West Mesa" profile compares well with the earlier one of Hamilton (1970) [dotted line] for the west flank of the Salton Trough. 
to $8 \mathrm{~km}$ in the East Pacific and Cocos Plates. There, by analogy with ophiolite sequences, the lower crust appears to be a transition from sheeted dike swarms of diabase above to gabbro below (Lewis, 1978). Second, direct evidence for mafic intrusions beneath the Salton Trough comes from the occurrence of diabase dikes in geothermal wells in the SSGF (Robinson et al, 1976), the East Brawley field (Keskinen and Sternfeld, 1982), the Heber field (Browne and Elders, 1976; Browne, 1977), the Cerro Prieto field (Elders et al, 1981) and the Mesa de Andrade field (Figure 3-1). Furthermore, xenoliths of diabase, basalt, and gabbro occur in the Quaternary rhyolite domes within the Salton Sea geothermal field (Robinson et al, 1976).

These models of seismic velocity structure were then used by fuis et al (1982) to constrain a new, more detailed gravity model for the Salton Trough (Figure 3-6). This east-west cross-section extends from the Pacific Coast at La Jolla, just north of San Diego, across the Peninsular Ranges, over the Salton Trough in the vicinity of Brawley, and finally to the Chocolate Mountains, east of the Imperial Valley. Although the model is only twodimensional and is not oriented SW-NE, which would be perpendicular to the structural grain of the Trough and the general trend of isogals within it, certain implications are clear (Figure 3-6).

Because of the positive gravity anomaly along the axis of the Trough, the proposed layer of mafic intrusive rocks in the lower basement (model density $3.1 \mathrm{~g} / \mathrm{cm}^{3}$ ) more than compensates for the low-density sediments above (model densities $2.3-2.55 \mathrm{~g} / \mathrm{cm}^{3}$ ). The relatively flat gravity profile across the Salton Trough also implies that variations in the thickness of these lowdensity sediments are compensated by variations in the thickness of the highdensity layer. The negative gravity anomalies under the crystalline rocks of the Peninsular Ranges and the Chocolate Mountains require that the mafic layer is absent or deeper beneath the mountains bordering the Trough (Fuis et al, 1982).

\subsection{VOLCANISM IN THE SALTON TROUGH}

In addition to the minor intrusions penetrated in boreholes, surface Quaternary volcanic rocks occur in two locales in the Salton Trough. The young volcanoes at Cerro Prieto and the SSGF are apparently part of the suite 

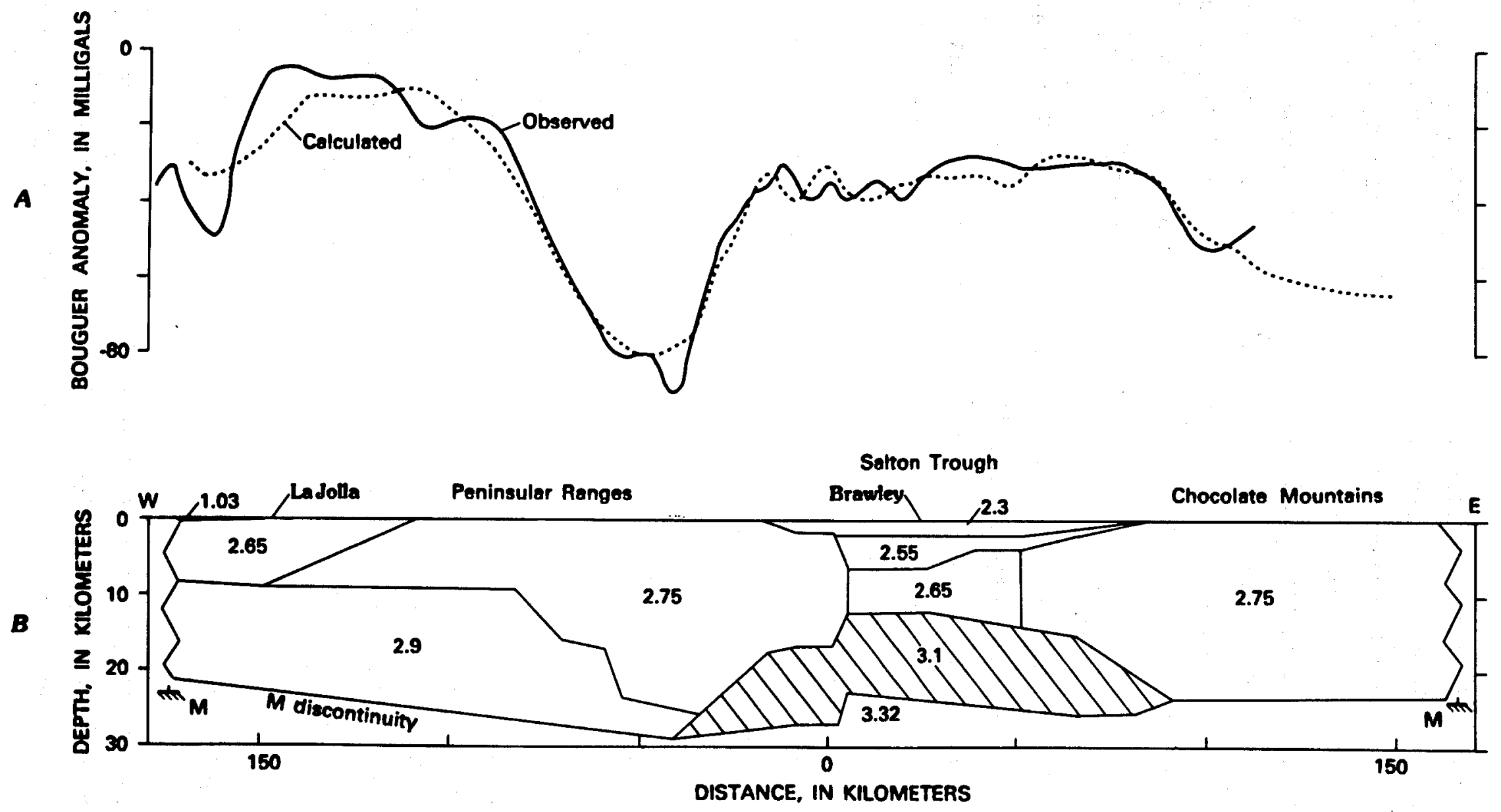

Figure 3-6. East-Northeast Section Across the Salton Trough.

$A=$ gravity profile. $B=$ model, where densities are in $\mathrm{gm} / \mathrm{cm}^{3}$. Hachured area is a dense "subbasement" of almost mantle density. Depth to Moho, at ends of section, is designated " $M$ " and was determined by seismic refraction. Depth to Moho in Salton Trough is not constrained by seismic data (Source - Fuis et al, 1982). 
of volcanic activity associated with the East Pacific Rise and the Gulf of California. Basalt dredged from the deep basins and occurring on the islands in the Gulf is olivine tholeiite similar to that found on the East Pacific Rise and other ocean spreading centers (Kay et al, 1970; Batiza, 1978). Cores of similar basalt, together with hydrothermally altered sediments of greenschist facies, were also recently obtained by the Deep Sea Drilling Project in the Guayamas Basin (Curry et al, 1979).

The Cerro Prieto volcano is a lithoidal, calc-alkaline rhyodacite (Table 3-1) cone, which appears to be the product of a single eruptive cycle. The marked lack of erosion of the cone attests to the relatively youthful age of this eruption. Although it has not been precisely dated as yet, it is known to be magnetized in the Recent normal polarity interval and is therefore certainly younger than 700,000 years and probably younger than 100,000 years (Elders, 1979). Such calc-alkaline rhyodacite volcanism appears to be characteristic of the Pleistocene Gulf of California (Gastil et al, 1979).

At the south end of the Salton Sea are five small extrusive rhyolite domes arranged along a northeast trend. These domes, collectively known as the Salton Buttes, were extruded onto Quaternary alluvium. A single $\mathrm{K}-\mathrm{Ar}$ age determination on the westernmost dome, Obsidian Butte, gave an age of approximately 16,000 years (Muffler and White, 1969). Two' of the domes, those at Red Hill, are linked by subaqueous pyroclastic deposits; the others are single extrusions with or without marginal lava flows. All of the domes consist of low-calcium, alkali rhyolite with only 1 to 2 percent crystals (Table 3-1). Similar rocks recovered from geothermal wells have been altered extensively by water-rock reactions. The fresh rhyolites are identical in composition to soda rhyolites erupted on the islands of the East Pacific Rise and have similar primitive $\mathrm{Sr}^{86} / \mathrm{Sr}^{87}$ ratios (Robinson et al, 1976). Basaltic rocks occur as xenoliths in the domes and as subsurface dikes, sills, or flows. Except where hydrothermally altered by brines, these rocks are also similar to low-potassium tholeiltic basalts erupted on the East Pacific Rise and on islands in the Gulf of California (Robinson et al, 1975). These observations support the hypothesis that the conditions that control magma genesis under the Salton Trough and the Gulf of California are similar to those operating beneath oceanic spreading centers (Elders, 1979). 
Table 3-1. Chemical Analysis of Volcanic Rocks in the Salton Trough

\begin{tabular}{lccc}
\hline & $\begin{array}{c}\text { Cerro Prieto } \\
\text { (Average of 2) }\end{array}$ & $\begin{array}{l}\text { Obsidian Butte } \\
\text { (Salton Buttes) } \\
\text { (Average of 5) }\end{array}$ & $\begin{array}{c}\text { Basalt Xenoliths } \\
\text { (Sal ton Buttes) } \\
\text { (Average of 4) }\end{array}$ \\
\hline $\mathrm{SiO}_{2}$ & 68.62 & 73.6 & 52.19 \\
$\mathrm{TiO}_{2}$ & 0.54 & 0.04 & 1.79 \\
$\mathrm{Al}_{2} \mathrm{O}_{3}$ & 15.58 & 13.5 & 14.73 \\
$\mathrm{Fe}_{2} \mathrm{O}_{3}{ }^{*}$ & 5.59 & 2.8 & 9.63 \\
$\mathrm{MnO}_{\mathrm{MgO}}$ & 0.10 & 0.05 & 0.17 \\
$\mathrm{MaO}$ & 0.87 & 0.21 & 6.79 \\
$\mathrm{Na}_{2} \mathrm{O}$ & 4.68 & 0.9 & 10.36 \\
$\mathrm{~K}_{2} \mathrm{O}$ & 2.73 & 4.5 & 3.57 \\
$\mathrm{Total}$ & 1.29 & 4.1 & 0.42 \\
\hline
\end{tabular}

*Total $\mathrm{Fe}$ as $\mathrm{Fe}_{2} \mathrm{O}_{3}$

Source - Elders (1979). 
Numerous partly melted granitic xenoliths in these rhyolite domes show various degrees of either cotectic melting along quartz-feldspar boundaries or disequilibrium incongruent melting of hydrous ferromagnesian minerals. These granite inclusions contain notably higher $\mathrm{SiO}_{2}, \mathrm{CaO}$, and $\mathrm{Na}_{2} \mathrm{O}$ and lower total iron than the enclosing rhyolite. The compositions and textures of these rocks suggest that they are fragments of continental basement rather than being cogenetic with the rhyolites. This idea is also supported by their strontium isotopes, which show that they are not cognate xenoliths. Whereas the ratio ${ }^{87} \mathrm{Sr} /{ }^{86} \mathrm{Sr}$ of the rhyolite is 0.705 , that in the granitic xenoliths is $\mathbf{0 . 7 2 0}$. As mentioned above, these granitic xenoliths are accompanied by basaltic xenoliths and by inclusions of unaltered sediment and hydrothermally altered sediment. Since partial melting is only seen in the granitic xenoliths, they probably come from a level deeper than the sediments and metasediments. Perhaps these highly melted granite fragments came from the lower basement where they occur as septa between multiple sheeted dike swarms. Alternatively, melting of arkose at the bottom of the sedimentary pile might produce textures and compositions similar to those observed in the granitic xenoliths (Elders, 1979).

\subsection{STRUCTURAL EVOLUTION OF THE SALTON TROUGH}

As indicated in section 3.1, the Salton Trough is an example of a complex rift valley. Figure $3-7$ is a simple two-dimensional cartoon relating rifting to the crustal thinning required by the gravity and seismic data. In the first stage, two layers of continental crust are shown before spreading initiated. As spreading begins, upward extension and lateral rifting of the crust is accompanied by thermal expansion and metamorphism caused by hot zones in the upper mantle. Ductile thinning of the lower crust and brittle, tensional failure in the upper crust generates a widening trough which receives low-density sediments. Since rifting and sedimentation are contemporaneous, older sediments are deformed and faulted and younger sediments grow progressively thicker toward the axis of the valley.

In the third stage, the upper mantle produces basaltic magma which invades and metamorphoses the lower crust. This efficient process of heat transfer causes greater thermal metamorphism of the sedimentary pile and even 

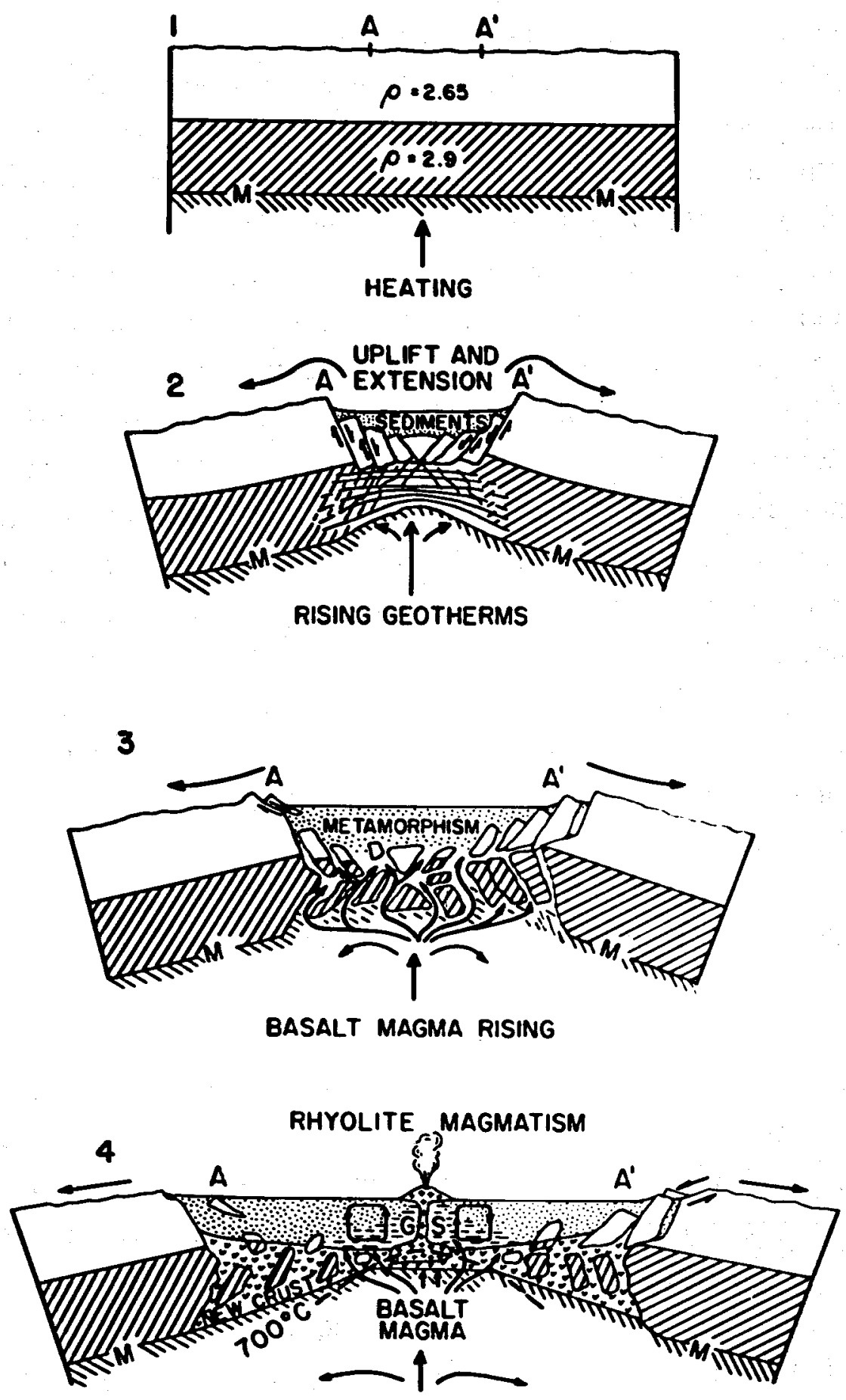

Figure 3-7. Model of Rifting and Magma Generation for the Salton Trough

The sections are drawn parallel to strike-slip faults. Two layers of crust overlie a hot zone in the mantle. $M=$ Moho discontinuity, $A$ and $A^{\prime}=$ reference points for later movements, GS = greenschist metamorphism. See text for explanations (Source - Elders et al, 1972). 
more thinning of the crust away from what is now an active spreading center. Tilting of the valley walls causes gravitational sliding of uplifted basement toward the rift valley. The basement beneath the trough is now new crust, of more oceanic type, created by intrusion of basaltic magma into the older continental crust and younger sediments (Elders et al, 1979).

Plumes of hot brine are largely responsible for the development of greenschist metamorphism in the sediments. When the $700 \mathrm{C}$ isotherm rises high enough into the crust, granitic basement rocks begin to melt. Finally rhyolitic magma from the mantle entrains fragments of basalt, metamorphosed sediments, and granitic basement.

The two-dimensional model (Figure 3-7) was deliberately oriented to omit the important transiational motions on the major transform faults in the region. The cross sections are oriented parallel to and between major strike-slip faults and, therefore, oblique to the valley. In order to relate this cartoon to these faults it is necessary to consider deformation on a larger scale (Elders et al, 1972).

More than 50 years ago Wegener, as part of his comprehensive scheme of continental drift, proposed that the $1500 \mathrm{~km}$ long tectonic depression of the Gulf of California formed by separation of the peninsula of Baja California from mainland Mexico (Wegener, 1924). This idea remained dormant until the advent of plate tectonics.

Paleontological evidence suggests that the Gulf of California has existed for the last 15 million years. Marine foraminifera of late Miocene to early Pliocene age attest to the existence of deep water in the Gulf from 11 to 6 million years ago (Ingle, in Elders and Biehler, 1975). At this time the Gulf may have been about two-thirds its present size, having formed as a volcanotectonic rift zone similar to the rifts commonly formed behind island arctrench systems. The mechanism responsible for the formation of this proto-Gulf is not clear.

We can also ask in what way is the modern Gulf related to strike-slip faulting? This problem was discussed by Carey (1958) who, before the theory of plate tectonics was formulated, coined the term "rhombochasm" to describe the tensional gap formed between en echelon pairs of strike-slip faults. The idea is particularly appealing in the case of the southern two-thirds of the Gulf, where marine geophysical surveys have revealed numerous young 
topographic depressions in the Gulf floor bounded by seismically active faults. These closed basins have heat flows several times the crustal average, have positive gravity anomalies of up to $+80 \mathrm{mgal}$, and appear to have been produced by active movement along en echelon fault segments (Moore, 1973).

Lomnitz et al (1970) and Elders et al (1972) both suggested that this pattern of transform faults and "pull-apart" basins persists further north into the Salton Trough. On land, however, the basins were filled as rapidly as they formed by deltaic sedimentation (Figure 3-7). Depressed areas on either side of the apex of the Colorado River delta may be subtle expressions of such tectonic subsidence that have not been obliterated by sedimentation. The en echelon arrangement of the western boundary of the Imperial Valley, with its numerous low embayments, also supports this idea. Figure 3-8 shows a possible arrangement of tension "pull-apart" basins, compression zones, and strike-slip faults. As an explanation of the numerous active faults diverging northwest from the Salton Trough, Lomnitz et al (1970) suggested that rates of spreading on individual "spreading centers" decrease progressively northward. Elders et al (1972) pointed out the consequences of such a model (Figure 3-8A). If spreading centers $X, Y$, and $Z$ have velocities of spreading $V_{1}, V_{2}$, and $V_{3}$, respectively, the velocity of movement on the fault $D C$ is $\left(V_{1}+V_{2}\right)$, but on the extension of this fault CC' it is only $\left(V_{1}-V_{2}\right)$. As indicated in Figure $3-8 \mathrm{~A}$, this model of faulting has a complementary system of left-lateral faults to the southeast. To our knowledge, such a system of left-lateral faults has not yet been reported either in the Gulf of California or in Sonora.

The simple conceptual model, shown in Figure 3-8A, is only one of many possible hypotheses for local patterns of spreading which might be related in a complex way to the overall relative motion of the lithosphere and asthenosphere in this region. In view of the youth of the valley and the rapidity of its growth, unstable and transient movements are also to be expected (Elders, 1979). 


$\begin{array}{ll}1 & 1 \\ 1 & 1 \\ 1 & 1 \\ 1 & 1 \\ 1 & 1\end{array}$
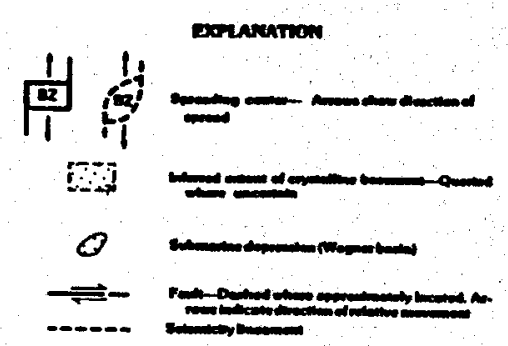

A.

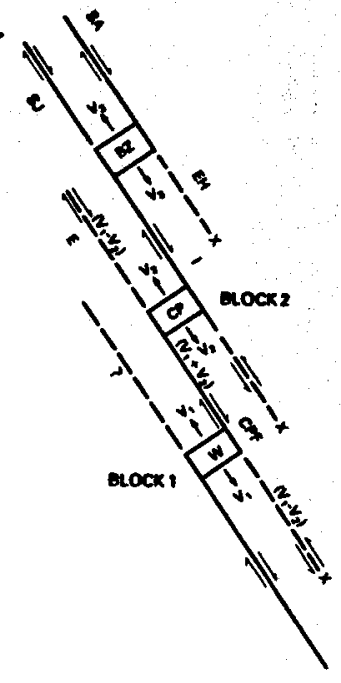

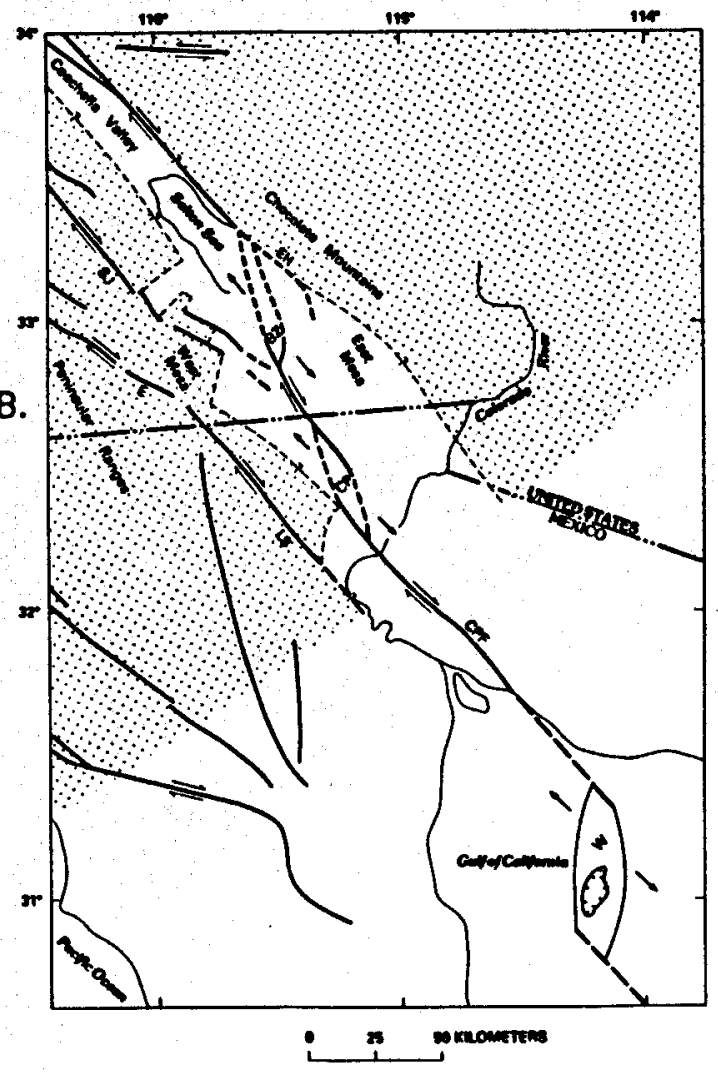

F1gure 3-8. Plate-tectonic Model and Map of Northern Gulf of Callfornia and Salton Trough.

Ideallzed model (A) of sketch map (B) illustrates interrelations of major spreading centers: Brawley seismic zone (BZ), Cerro Prieto geothermal area (CP), and Wagner Basin (W); major transform faults: San Andreas fault (SA), Imperial fault (1), Cerro Prieto fault (CPF): and major fracture zones or sutures: San Jac into fault zone (SJ). Elsinore fault (E), and East Highitne Canal seismicity lineament (EH). Laguna Salada fault (LS), mich appears to be the seismically most active extenston of Els on does not appear to conect wh a kny American cont inent, with its pre existing reaknesses, on oceanic plate tectonics. $x$ 's denote fracture zones or sutures that are inactive in indicated left-lateral sense. East Highline Canal seismicity lineament appears to be associated with nomal dip-slip motions; there is currently no seismic or geologic evidence for existence of other two proposed sutures. Inactivity along sutures on east side of Gulf of California and Salton Trough requires that spreading centers migrate northmestward from Block 2 at their spreading half-rates. assume that these half-rates decrease northmestward: $V_{3}<V_{2}<V_{1}$. Modifled from Elders and others (1972, Fig. 7) by Fuis et al (1982). 


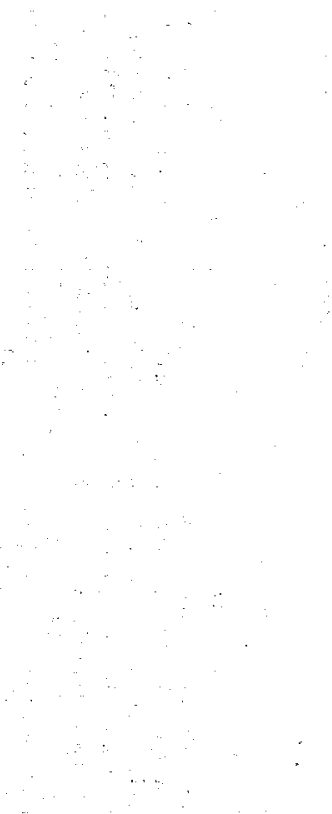




\subsection{HYDROTHERMAL SYSTEMS IN THE SALTON TROUGH}

\subsubsection{Regional Picture}

The Gulf of California and the Salton Trough are characterized by high regional heat flow. The deep basins within the Gulf geothermal anomalies can

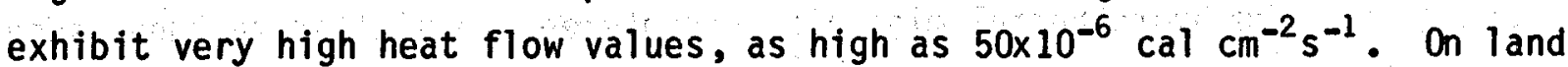
more than a dozen geothermal anomalies have been recognized. These anomalies include the Salton Sea, Westmorland, East Brawley, Brawley, Heber, East Mesa, Dunes, Glamis, and Border geothermal fields in the Imperial Valley, and the Cerro Prieto, Tulecheck, Panga de Abajo, Mesa de Andrade, Mesa de San Luis, and Desierto de Altar geothermal fields of the Mexicali valley (Figure 3-1).

An aspect of these geothermal fields that is important from the view of nuclear waste isolation is that they usually lack surface discharge or any other kind of surface expression even though they can have temperatures as high as $370 \mathrm{C}$ at $1,800 \mathrm{~m}$ depth. Only the Salton Sea and Cerro Prieto fields have any surface manifestations such as hot springs and fumaroles. Those two fields are also the only ones associated with Quaternary volcanoes. The remainder have been accidently discovered during the drilling of (dry) oil wells or by geophysical surveys using gravity, thermal gradient, or electrical resistivity measurements. The high thermal gradients, which are related to circulation of convecting hot groundwater in the thick sedimentary fill, coincide with low-amplitude, positive, residual-gravity anomalies with closures of 2 to $20 \mathrm{mgals}$ (Elders et al, 1972).

The chief exploration strategy used to discover and assess these "blind" geothermal systems was to measure heat flow in shallow boreholes drilled on positive gravity anomalies. The positive gravity anomalies associated with the themal anomalies reflect (1) the presence of shallow, dense igneous intrusions; and/or (2) the increased density of sediments due to hydrothermal alteration. Both are encountered in boreholes.

Based upon study of cuttings and cores recovered, the most pervasive source of excess mass, at least down to the level penetrated by drilling, is the hydrothermal alteration of sediments. For example, intense metamorphism of the sedimentary fill occurs in the SSGF. Active formation of greenschist facies rocks is occurring at depths of 1 to $2.5 \mathrm{~km}$ below the surface, where 
the temperature ranges up to $365 \mathrm{C}$ at $2 \mathrm{~km}$ depth (Muffler and White, 1969; MCDowell and Elders, 1979). Brines recovered from these depths contain up to 25 wt percent of total dissolved solids (Helgeson, 1968).

Although similar geothermal gradients are encountered in the Cerro Prieto geothermal field, the brine is much less saline. Typically the brine contains only 13-15,000 ppm of $\mathrm{Cl}, 7-8,000 \mathrm{ppm}$ of $\mathrm{Na}, 5-600 \mathrm{ppm}$ of $\mathrm{Ca}$, and 1,500-2,000 $\mathrm{ppm}$ of $\mathrm{K}$. The hydrothermal minerals encountered are similar to those seen in the Salton Sea field, but the degree of recrystallization is less intense. In both of these geothermal fields hydrothermal alteration affects the physical properties of the sediments by reducing porosity and increasing density. A transition in the nature of the permeability in these reservoirs therefore occurs - from matrix porosity in the upper part of the reservoir to fracture-dominated permeability at depth (Elders, 1979).

The Brawley and East Brawley geothermal fields appear to have temperatures and salinities intermediate to those of the Salton Sea field and the other identified geothermal fields of the Salton Trough. Temperatures in excess of $300 \mathrm{C}$ and salinities of $200,000 \mathrm{ppm}$ TDS have been encountered there. Although a dozen or so deep wells penetrate these reservoirs, little public information is available at this time.

Such high temperatures and highly saline brines have not been found in the other thermal anomalies drilled to date. Temperatures from 100 to $200 \mathrm{C}$ and brines containing from 3,000 to $20,000 \mathrm{ppm}$ total dissolved solids are much more characteristic. Similarly, the degree of metamorphism observed is characteristically less than that seen in rocks from the Salton sea and Cerro Prieto fields (Elders, 1979).

Surface expression of these thermal anomalies is retarded by impermeable caprocks. For example, the Salton sea geothermal field has an impermeable caprock of lacustrine clays up to $450 \mathrm{~m}$ thick (Helgeson, 1968; Randall, 1974). The Dunes hydrothermal system, on the other hand, developed an impermeable caprock by self-sealing. In the upper $300 \mathrm{~m}$ of a $612-\mathrm{m}$ deep borehole in the Dunes field, there are seven intervals of intense cementation of sandstone to quartzite, with densities as high as $2.55 \mathrm{~g} / \mathrm{cm}^{3}$ and porosities as low as 3 percent (Elders and Bird, 1974; Bird, 1975).

The hottest geothermal fields (Salton Sea - 365 C, Cerro Prieto - $370 \mathrm{C}$, and Brawley $-300 \mathrm{C}$ ) are all situated in young pull-apart zones. The other 
geothermal fields such as Heber and East Mesa are associated with the less active extensions of the transform faults (e.g., EH and $E$ in Figure 3-8B). These geothermal fields are under active development as sources of steam for generation of electricity. The most developed is the Cerro Prieto field in Mexico, which already has an installed capacity of 180 MWe and two plants each of 220 MWe under construction. For environmental and technical reasons, development of geothermal power sources has been slower in the Imperial Valley. At this point only pilot scale plants, with net ratings of about 10 MWe, exist at the East Mesa, Brawley and Salton Sea sites. According to published estimates of the U.S. Geological Survey (Muffler, 1979), the geothermal resources avallable for power generation north of the international border are sufficient to generate 2,000 MWe for a century. This estimate, based upon data avallable in 1978, must be regarded as a minimum value. The subsequent discovery of the East Brawley field and recent developments and step-out drilling in the existing fields suggests that the source may be much larger (see discussion in section 4.1.1). Because much of these new data are proprietary, however, a precise estimate cannot be made at present.

\subsubsection{Heat Sources}

There are two classes of geothermal systems in the Salton Trough: (1) moderate temperature systems, such as Heber and East Mesa, with temperatures $\leq 200 \mathrm{C}$ at $2 \mathrm{~km}$ depth; and (2) high intensity systems such as Brawley, East Brawley, Salton Sea and Cerro Prieto, with temperatures of $\geq 300 \mathrm{C}$ at $2 \mathrm{~km}$. Maximum measured temperatures reported to date are $370 \mathrm{C}$ at Cerro Prieto and $365 \mathrm{C}$ at Salton Sea.

Although dikes or sills were penetrated in drilling at Heber (Browne and Elders, 1976; Browne, 1977), apart from the high heat flow, a geophysical signature or other indication of large nearby intrusions associated with these moderate temperature fields has not been observed. The heat source for these moderate temperature systems is probably deep circulation of ground water, possibly fault controlled, in an area of regionally high heat flow. The lack of large positive gravity and magnetic anomalies associated with these moderate temperature fields suggests that minor intrusives are not sufficiently abundant to be heat sources. 
Similarly, a series of multiple dikes or sills 3 to $35 \mathrm{~m}$ thick and ranging in composition from andesite to basalt, which were encountered in a well in the East Brawley field, is too old to be a heat source for the modern system. Potassium-argon dates for these rocks gave early Pliocene ages (8.1 $10.5 \times 10^{6}$ years) according to Keskinen and Sternfeld (1982).

In contrast, as indicated above, two of the intense geothermal fields, the Salton Sea and Cerro Prieto systems, are associated with both minor intrusives and Quaternary volcanoes (Elders et al, 1981; Robinson et al, 1976). These two fields also have large gravity and magnetic anomalies suggestive of larger intrusions at depth as heat sources.

\subsubsection{Models of the Cerro Prieto Geothermal System}

Because it is by far the best studied geothermal field in the Salton Trough, the Cerro Prieto system, some $25 \mathrm{~km}$ south of the international border, can serve as a model for other high intensity systems. More than 110 wells, some deeper than $3 \mathrm{~km}$, penetrate this system and all of the information from this field is in the public domain. The Cerro Prieto field was the subject of an international cooperative study by the Comision Federal de Electricidad of Mexico (CFE) and the U.S. Department of Energy (DOE) in the period 1977 to 1982 in which the Geothermal Resources Program at the University of California, Riverside participated.

One result of this collaboration is a comprehensive model for the pattern of fluid flow in this field before production began (Elders et al, 1981). This model draws upon all available information and was based upon (1) the location of the natural surface discharges in an arc west of the field; (2) temperature gradients measured in wells; $(3)$ depths of the production zones in flowing wells; (4) depths to the first occurrence of various hydrothermal mineral zones, especially epidote and biotite; (5) isotope and fluid inclusion geothermometry; (6) estimates of the relative durations of heating from vitrinite reflectances; (7) the locations of zones of high and low electrical resistivity, based on downhole electrical logs; (8) the location of intrusive dikes in wells H2, NL-1, T-366 and M-189, along the eastern margin of the field; (9) correlations with surface surveys of DC electrical resistivity; and (10) the results from newer step-out wells. 
A key feature of this model is division of the field into four sections: (1) an area of cold water recharge to the northeast; (2) a zone of upward flowing boiling water in the center; (3) a region of surface discharge lying to the west; and (4) an aquifer at the extreme western boundary of the field in which flow of hot water is primarily horizontal. The model further inferred that this pattern was produced by hydrothermal convection in which a buoyant hydrothermal plume, dipping $45^{\circ}$ to the northeast, discharges to the southwest. Mass flow is recharged by cold water from the northeast which descends and is heated by a deep magmatic heat source in that direction (Figure 3-9).

The study of oxygen isotope and subsurface temperature data indicates that a reservoir volume of about $12 \mathrm{~km}^{3}$ has exchanged its oxygen isotopes with water at temperatures greater than $200 \mathrm{C}$. The measured $\delta^{18} 0$ shifts between unreacted sediments, hydrothermally altered sediments, and the waters yields a water to rock mass ratio of 1.33 or a volume ratio of approximatey 3 . Thus 36 $\mathrm{km}^{3}$ of water hotter than $200 \mathrm{C}$ reacted with the $12 \mathrm{~km}^{3}$ of the so-far explored reservoir, causing the observed isotopic exchanges (Elders et al, 1982).

Detailed studies of fission track annealing in detrital apatites in sandstones indicate that well T-366 on the eastern side of the field reached the temperature range $160-180 \mathrm{C}$ less than 10,000 years ago. If this age is generalized to the whole reservoir, it implies that the flux of $>200 \mathrm{C}$ water occurred in less than 10,000 years. This flux in turn requires a flow of more than $3.6 \times 10^{6} \mathrm{~m}^{3}$ of water a year through the whole reservoir in the natural state for approximately 10,000 years. If this fluid flowed through a cross section of the reservoir averaging $6 \mathrm{~km}^{2}$ in area, then the specific discharge would be $0.6 \mathrm{~m}^{3} /$ year. For an average porosity of 10 percent, the transport would then have been $6 \mathrm{~m}^{3}$ /year averaged over $10^{4}$ years (Elders et al, 1982 ). Rough estimates of the heat stored in the part of this geothermal reservoir hotter than $200 \mathrm{C}$, down to a depth of $3 \mathrm{~km}$, show that it is equivalent to the enthalpy contained in at least $1.5 \mathrm{~km}^{3}$ of molten basalt. For such a large amount of heat to be transferred into the sediments in 10,000 years by convection requires that the source of heat be both large and close. The Cerro Prieto geothermal field should therefore be considered as an active magma-hydrothermal system (Elders et al, 1982). 


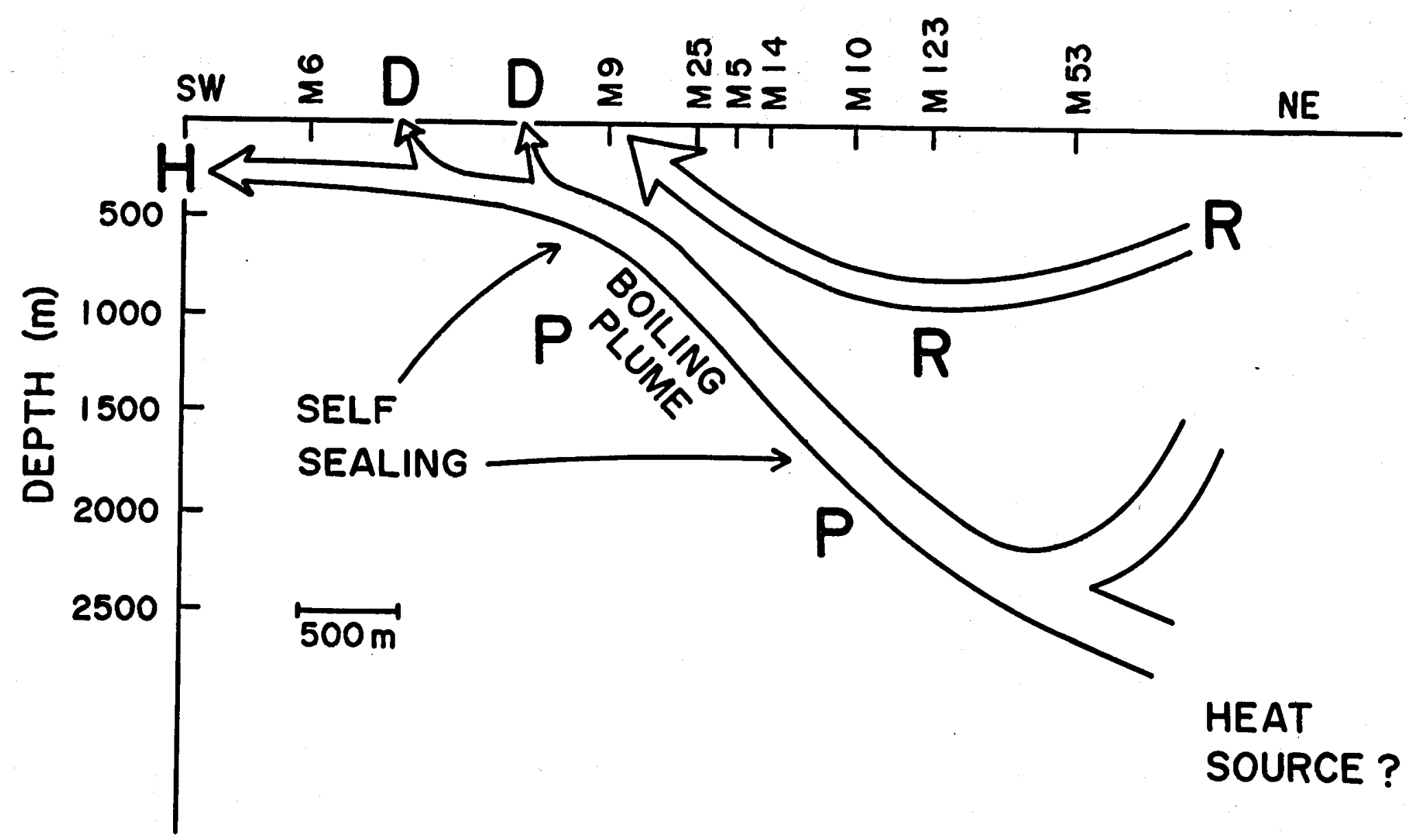

Figure 3-9. SW-NE Cross-section Showing the Flow Regime Proposed for Cerro Prieto.

M6, M9, etc. = Location of geothermal wells

$H=$ Zone of horizontal flow

$D=$ Zone of surface discharge

$P=$ Zone of rising plume of boiling water

$R=$ Zone of cold water discharge (see text)

(Source - Elders et al, 1981). 
Although the nearby Quaternary volcano of Cerro Prieto is a rhyodacite dome, two compelling reasons exist for assuming that the heat source for the field is a basaltic intrusion. Firstly, the dikes encountered in deep boreholes are largely diabase. Secondly, in this tectonic setting of crustal spreading associated with "leaky" transform faults of the San Andreas fault Gulf of California system, basalt intrusions are likely (Elders et al, 1972).

To quantify an estimate of the size, age, and location of a gabbroic heat source for the Cerro Prieto system, a series of numerical analog models of heat and mass transfer was generated by Elders et al (1983). The aim was to replicate the timing and temperature distribution in the observed part of the hydrothermal system. The first step was to calculate the enthalpy contained in the two cross-sections across the field. Next, simplifying assumptions were made on the distribution of rock permeability at depth. Then a series of numerical finite element models of conductive and convective heat transfer were computed for a series of different heat sources and different assumed permeabilities (Elders et al, 1982).

The two-dimensional numerical models which best fit the features of the field observed today have in common a funnel-shaped gabbroic intrusion, probably 3 to $5 \times 10^{4}$ years $01 \mathrm{~d}$, some 4 to $5 \mathrm{~km}$ across and with a top at a depth of 5 to $6 \mathrm{~km}$. The inclination of the thermal plume is apparently controlled by the asymmetry of the intrusion and by shallow permeability barriers that are presumably breached by faulting (Figure 3-10) (Elders et al, 1982).

If, as seems likely in this tectonic setting of crustal spreading, there have been repeated incursions of magma for a long period, then the intrusions must be even larger and have begun earlier. Above the heat source there is probably a sheeted dike complex, as is typical of ophiolite complexes formed at ocean spreading centers. Whatever its form, the existence of a young, large, shallow igneous intrusion seems inescapable (Elders et al, 1983).

Since these models were initially proposed, independent geophysical evidence for the presence of a gabbroic body beneath the Cerro Prieto field was proposed by Goldstein et al (1983). A broad dipolar magnetic anomaly $5 \mathrm{~km}$ east of the 180 MWe power plant at Cerro Prieto is modeled by a tabular block 4 by $6 \mathrm{~km}$ in area and $2.3 \mathrm{~km}$ thick, with a top $3.7 \mathrm{~km}$ deep. The susceptibility of the magnetic source is equivalent to that of a 


\section{PERMEABILITY (md)}

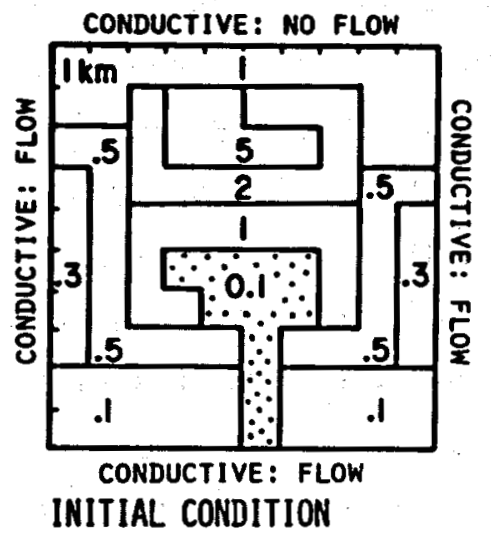

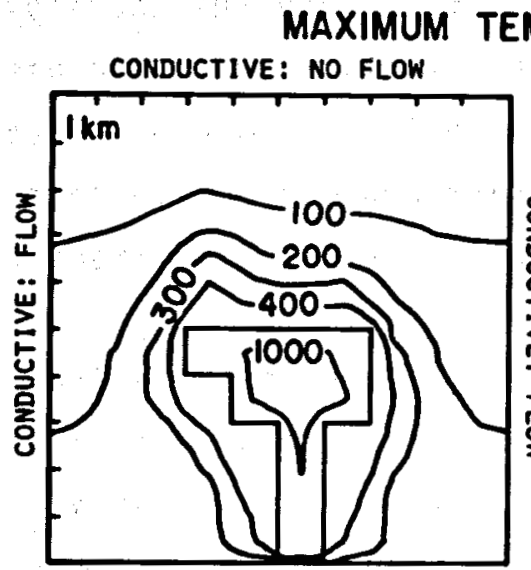

CONDUCTIVE: FLOW

20000 YEARS

CONDUCTIVE: NO FLOW

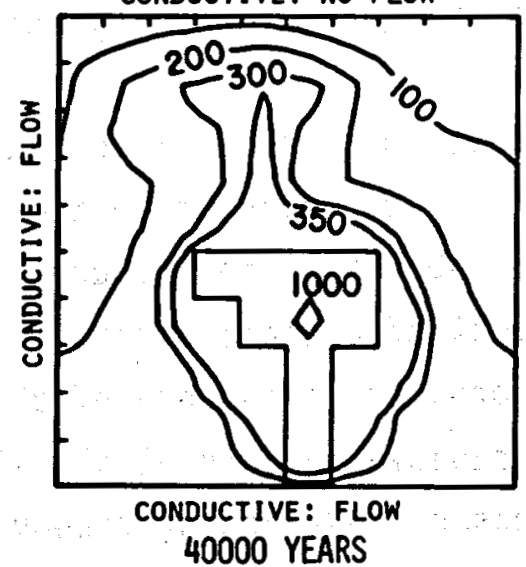

\section{TEMPERATURES $\left({ }^{\circ} \mathrm{C}\right)$}

CONDUCTIVE: NO FLOW

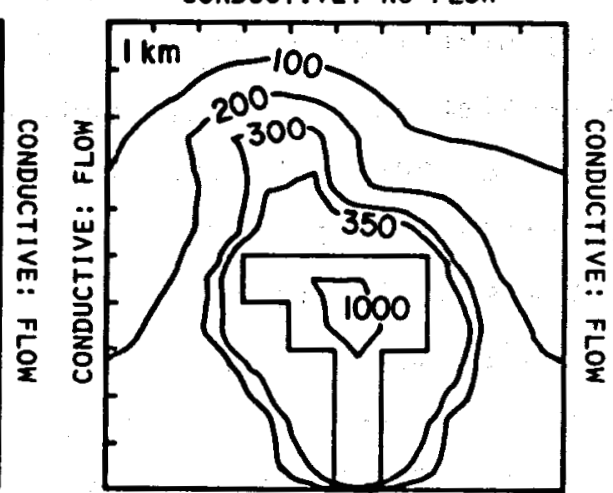

CONDUCTIVE: FLOW

30000 YEARS

CONDUCTIVE: NO FLOW

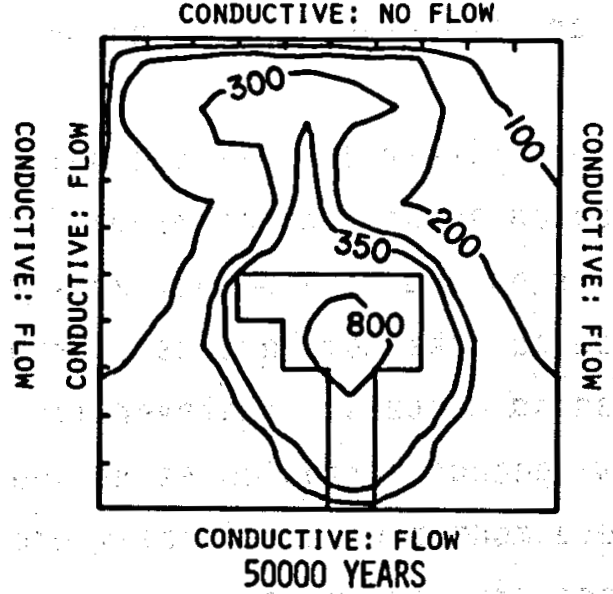

Figure 3-10. Two-dimensional Heat Transfer Model for the Cerro Prieto Geothermal Field.

Initial condition and temperatures for four time steps. The upper model shows the permeability in millidarcies at the time of emplacement of the intrusion (which is stippled) (Source Elders et al, 1982, Fig. 15). 
magnetite-bearing gabbro. The base of this magnetic source at $6 \mathrm{~km}$ appears to be the Curie isotherm for magnetite $(575 \mathrm{C})$. A linear extrapolation of temperature gradients from well logs through the depth of the Curie isotherm suggests a melt zone at a depth of 9 to $10 \mathrm{~km}$ (Goldstein et al, 1983).

This depth is consistent with the model of Elders et al (1983) which shows the upper kilometer of the postulated pluton having cooled below $800 \mathrm{C}$ at $6 \mathrm{~km}$ depth in 50,000 years. Thus the concepts that large, young gabbroic intrusions occur beneath the high temperature geothermal fields of the Salton Trough and that these intrusions may still be molten at depths of 6 to $9 \mathrm{~km}$ seems plausible.

\subsection{GROUND WATER IN THE SALTON TROUGH}

Water wells and wells drilled in the search for oil and geothermal resources in the Salton Trough penetrate a variety of waters that differ in isotopic ratios and salinity. These data are used not only to determine the origin of the water and the salt, but also to determine the degree of interaction of a given groundwater sample with a hydrothermal system.

\subsubsection{Oxygen and Hydrogen Isotope Investigations}

The primary stable isotopic species in water are $\mathrm{H}_{2} \mathrm{O}^{16}, \mathrm{H}_{2} \mathrm{O}^{18}$, and $\mathrm{HDO}^{16}$ (where $D=$ deuterium). The ratio of these species can be employed for a variety of hydrological investigations. Craig (1963) showed that stable isotope measurements are useful in determining the origin of water in geothermal systems because:

(1) The oxygen and hydrogen isotopic compositions of meteoric precipitation differ from one locality to another due primarily to differences in the temperature of precipitation. Craig (1961) found a linear correlation between $\delta D$ and $\delta^{18} 0$ for meteoric water samples from all over the earth such that

$$
\delta D=8 \delta^{18} 0+10 .
$$

Samples from colder locations are more negative in $\delta D$ and $\delta^{18} 0$ while precipitation from equatorial zones is closer to Standard Mean Ocean Water (SMOW). 
(2) A geothermal system has negligible effect upon the hydrogen isotopic composition of the water flowing through the system because the quantity of hydrogen in rocks is so low. The hydrogen isotopic composition of precipitation which enters a ground water system and flows through it is generally unchanged. Hudrogen isotopic compositions can thus serve to "tag" waters from different sources.

(3) The oxygen isotopic composition of precipitation which enters a geothermal system can be modified if the system is sufficiently hot $(>100 \mathrm{C})$ due to exchange of oxygen in water with oxygen in the rock. The net effect is to increase the ${ }^{18} 0$ content of the fluid and decrease that of the rock, giving rise to the well known shift of ${ }^{18} 0$.

Figure $3-11$ plots $\delta D$ versus $\delta^{18} 0$ for waters from the Imperial valley (Coplen et al, 1975) and compares them with the meteoric water line of Craig (1961). Coplen et al (1975) showed that waters from irrigation wells in the central Imperial Valley plot on a line connecting lower Colorado River water (Lake Mead) to surface water from the Salton Sea, at the lowest point of the closed basin. This regular relationship indicates that the non-geothermal waters of the valley follow a trend of evaporation, becoming heavier in both hydrogen and oxygen as the subsurface flow moves northward. This isotopic relationship is consistent with the hydrologic studies of Loeltz et al (1975), which indicate that groundwater recharge into the Imperial valley occurs almost exclusively by inflow of the Colorado River at Yuma, Arizona. Only near the margins of the Trough in a few shallow aquifers is there significant water derived from local precipitation, as shown by the solid circles in Figure 3-11 (Coplen et al, 1975).

Isotopic ratios of three selected geothermal systems are also plotted in Figure 3-11. A typical high-intensity geothermal sample (Cerro Prieto) shows an isotopic shift of about 3 per mil in oxygen due to water-rock reactions at high temperatures. Samples from a moderate temperature geothermal system (East Mesa, in which temperatures do not exceed $200 \mathrm{C}$ at $2 \mathrm{~km}$ ) and a low temperature geothermal system (the Dunes, with temperatures of $100 \mathrm{C}$ at $600 \mathrm{~m}$ ) plot close to the evaporation line. These isotopic data suggest that the waters in these geothermal systems are derived from evolved and evaporated Colorado River water and have not reacted with rocks to exchange oxygen at temperatures greater than $200 \mathrm{C}$. Because there is little oxygen exchanged in 


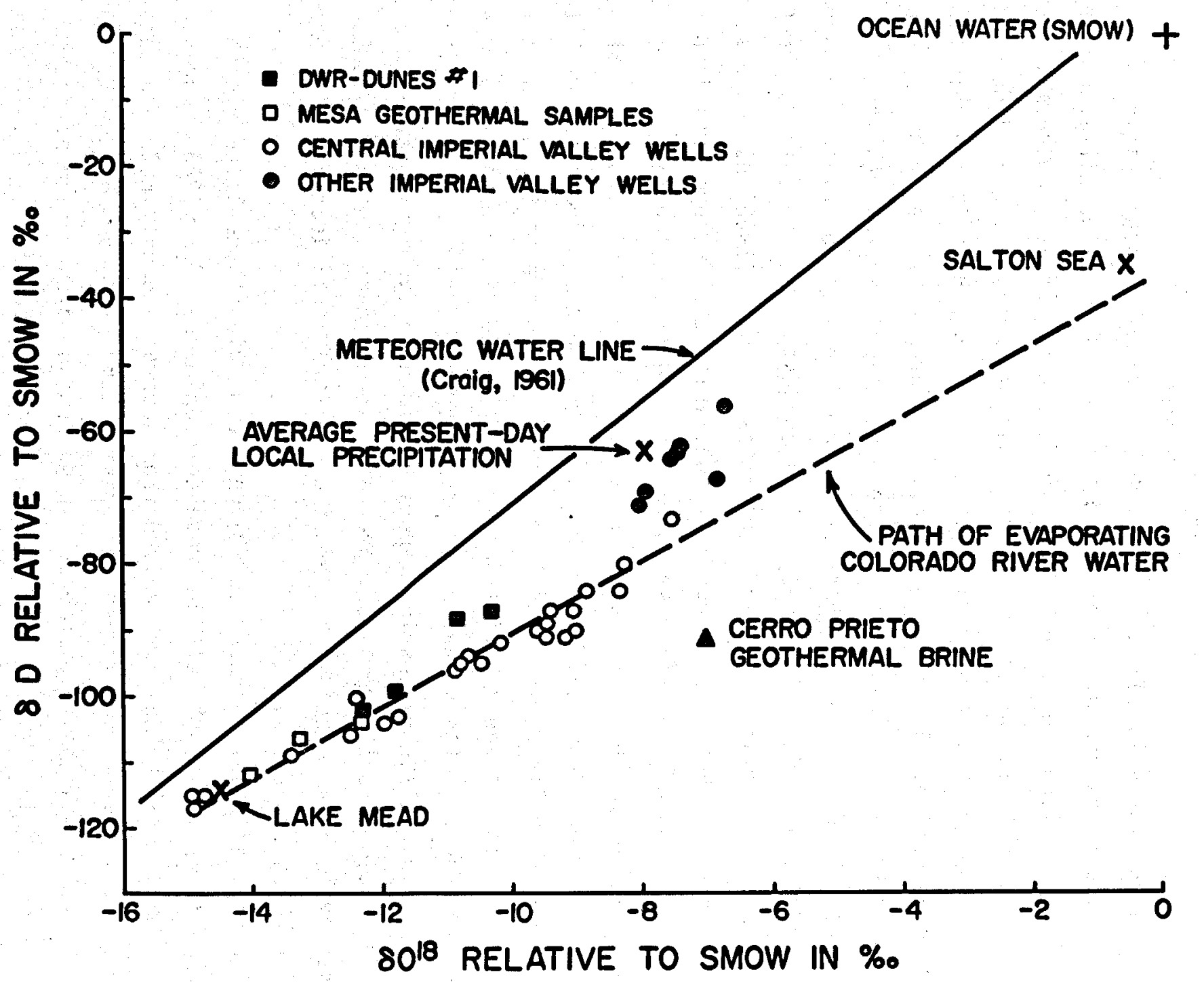

Figure 3-11. $\delta D$ Versus $\delta^{18} 0$ of Hydrothermal and Well Water Samples from the Imperial Valley Area.

(Source - Coplen et al, 1975, Fig. 3). 
these low to moderate temperature systems, a water/rock ratio for oxygen cannot be determined (Coplen et al, 1975).

\subsubsection{Brine Types}

All deep waters in the Salton Trough are primarily $\mathrm{NaCl}$ brines. The origin of the salts and waters in a geothermal system may be different; this possibility is discussed by Rex (1972) for the Cerro Prieto geothermal system. Although the isotopic ratios of the water suggest parly evaporated Colorado River water as the source of fluids at Cerro Prieto, the salts in this system appear to be marine. The ratio of chloride to bromide in water has been used to investigate the origin of salt in these geothermal systems (White, 1970; Rex, 1972). $\mathrm{Cl} / \mathrm{Br}$ ratios in waters of the ocean and Cerro Prieto geothermal field are 300 and 400 , respectively. This suggests that the salt in the Cerro Prieto system is marine in origin. In contrast, White (1968) has suggested that the very saline brine in the SSGF (containing $280,000 \mathrm{ppm}$ TDS) is derived from the solution of evaporites which were formed from Colorado River water (containing $800 \mathrm{ppm}$ TDS). Because the ratio $\mathrm{Cl} / \mathrm{Br}$ of water from both the SSGF and from DWR Dunes No. 1 (4000 ppm TDS) is 1600 , which is identical with that from the Colorado River, it seems likely that the source of the salts in the geothermal fields of the Imperial Valley is Colorado River water (Coplen et al, 1975). However, the situation is probably not so simple. Rex (1972) pointed out that $\mathrm{Cl} / \mathrm{Br}$ ratios in evaporites are usually highly variable and the $\mathrm{Cl} / \mathrm{Br}$ ratio of salt from local precipitation is much lower than 1600 . Thus it may be only coincidental that the $\mathrm{Cl} / \mathrm{Br}$ ratio is identical in these three hydrologic systems.

More recent studies by Rex (1983) on the origin of the brines in the Imperial Valley point out some of these complexities. Rex (1983) suggested that the geothermal brines are derived from several sources including local precipitation, fossil lake waters from former lakes formed when the flow of the river filled the basin with brackish water, and dissolution of the saline residue from dehydration of these lakes. According to Rex (1983), because rocks contain very little $\mathrm{Cl}$ and $\mathrm{Br}$, the $\mathrm{Cl} / \mathrm{Br}$ ratio is unaffected by geothermal processes and serves as a useful genetic and mixing tracer. On this basis Rex (1983) recognizes six types of subsurface brines in the Salton Trough: 
Type 1 is a deep metamorphosed brine resulting from chemical equilibration of cold hypersaline $\mathrm{NaCl}$ brine with rocks hotter than $300 \mathrm{C}$ : they are convectively mixed and have $\mathrm{Cl} / \mathrm{Br} \cong 20,000$. Type 2 shows variable salinity with temperature and is compositionally graded as salinity increases, with temperature balancing salinity as described by Helgeson (1968): $\mathrm{Cl} / \mathrm{Br}$ range from 1,200 to 1,300 due to mixing Type 1 brine with Type 3.

Type 3 is a hypersaline brine significantly modified by mixing with fossil lake waters (Type 4). This mixing causes precipitation of metal sulfides, sulfates, oxides, and carbonates in the host rock. The resultant brine has a lower $\mathrm{Cl} / \mathrm{Br}$ ratio due to the higher $\mathrm{Br}$ content of Type 4 water.

Type 4 is water from ancestral Lake Cahuilla.

Type 5 is local precipitation runoff originating from marine air. It is concentrated by evaporation and enriched in sodium and bicarbonate by reaction with rocks at low temperatures.

Type 6 is the unreacted underflow of brackish water entering the valley from the Colorado River drainage.

In addition, Rex (1983) postulates a hypothetical Type 0 brine which is brine formed at $20 \mathrm{C}$ by saturating water by halite. Type 0 would have a density of 1.2 , would form within the salinas of the Salton Trough, and could descend along fracture networks into the reservoir. According to Rex (1983) the Heber and East Mesa fields contain mainly Type 4 waters. South Brawley, East Brawley, and the Salton Sea geothermal fields contain Type 2 brines. Type 1 brine is apparently found in the I.I.D. \#1 well in the SSGF which has the highest chlorinity of any of the wells. 


\section{THE SALTON SEA GEOTHERMAL FIEI D}

\subsection{INTRODUCTION}

The Salton Sea Geothermal Field (SSGF) is one of the best known geothermal fields in the world. Although not as extensively drilled as Cerro Prieto, the SSGF is well-known because it was one of the first fields to be drilled in the U.S.A. for a source of electric power, because of its great size, and because of its high temperature gradients. The SSGF is also well known for the problems that its highly saline brines pose for power production, and for the opportunities and challenges presented by the high content of metals the brines contain.

\subsubsection{Resource Estimates}

According to Muffler (1979), the reservoir volume of approximately 116 $\mathrm{km}^{3}$ explored by drilling to that time, and having a mean temperature of $330 \mathrm{C}$, contained about $1 \times 10^{20}$ Joules. Assuming a porosity of 20 percent and assigning a reasonable recovery factor and thermal efficiency factor, the estimated electrical energy potential for the SSGF is 3400 MWe for 30 years (Muffler, 1979). On the other hand, Meidav and Howard (1979) point out that Lee and Cohen's (1979) shallow heat flow data indicate that the area exhibiting conductive heat flow greater than $200 \mathrm{milliwatts} / \mathrm{m}^{2}\left(4.8 \times 10^{-6}\right.$ cal $\mathrm{cm}^{-2} \mathrm{~s}^{-1}$ ) may cover more than $560 \mathrm{~km}^{2}$. Meidav and Howard (1979) therefore suggested that a reservoir $2 \mathrm{~km}$ thick underlying this area, with a mean temperature of $265 \mathrm{C}$, should contain $5.86 \times 10^{20}$ Joules. Thus their estimate of the recoverable energy is 19,900 MWe for 30 years, six times that made by the USGS. Based upon the area of the magnetic and gravity anomaly associated with the field, Younker and Kasameyer (1978) estimated the recoverable heat to lie between 870 and 5800 MWe for 30 years. The true size of the resource can only be determined by extensive well-testing and reservoir engineering analyses. Unfortunately the data from many studies are proprietary and hence these analyses have not been done on a field-wide basis.

In spite of the evident large size of the resource, the first power plant within the field, a 16 MWe (gross) pilot-scale plant, has been operated for 


\section{$53 / 54$}

only the last year by the Southern California Edison Company (location in Figure 4-1). The slow rate of commercial development is due to the environmental and technical problems of handling brines containing 28 wt percent TDS. These problems include both corrosion and scaling. Since their first discovery, however, the brines have also presented the challenge of using them as a source of recoverable metals (White et al, 1963).

Recently Maimoni (1982) estimated the potential for minerals recovery from a 1000 MWe combined geothermal power and minerals recovery plant in the SSGF. This author pointed out that a 1000 MWe plant, selling electric power at 6 cents/kWh, would earn $\$ 394$ million/year in 1982 U.S. dollars. This plant would require a brine flow rate of $45 \mathrm{million} \mathrm{kg} / \mathrm{h}$. Assuming 90 percent of the mineral values would be recovered, the market value of the minerals produced would be about $\$ 500$ to $\$ 1,500 \mathrm{million} /$ year. The wide range reflects the uncertainties about the content of precious metals. The estimate excludes lithium since the potential production from the SSGF could be an order of magnitude greater than the 1980 total world sales. The plant could supply 14-31 percent of the U.S. demand for manganese, a strategic material. This brine field may also potentially constitute the largest reserve of platinum in the U.S.A. (Maimoni, 1982). In spite of the large value of the metals in solution which would pass through such a plant, however, it is by no means clear that the techniques available to recover them would be economic at the present.

\subsubsection{History of Development}

Geothermal fields in the Salton Trough are typically cryptic, i.e., they are not associated with surface manifestations of geothermal activity such as hot springs, geysers, mud pots, or fumaroles except for the Cerro Prieto and Salton Sea geothermal fields. In 1540 , only 48 years after Columbus' discovery of America, Melchor Diaz followed the Gulf of California northward and penetrated overland into the delta of the Colorado until turned back by "fields of boiling mud" (Pourade, 1971). This could have been either at Laguna Volcano, at Cerro Prieto, or at Mullet Island in the Salton Sea.

Mullet Island (Figure 4-1) is one of the five small rhyolite domes associated with the SSGF (Robinson et al, 1976). Live steam fumaroles, mud 
$\mathcal{U}$ 


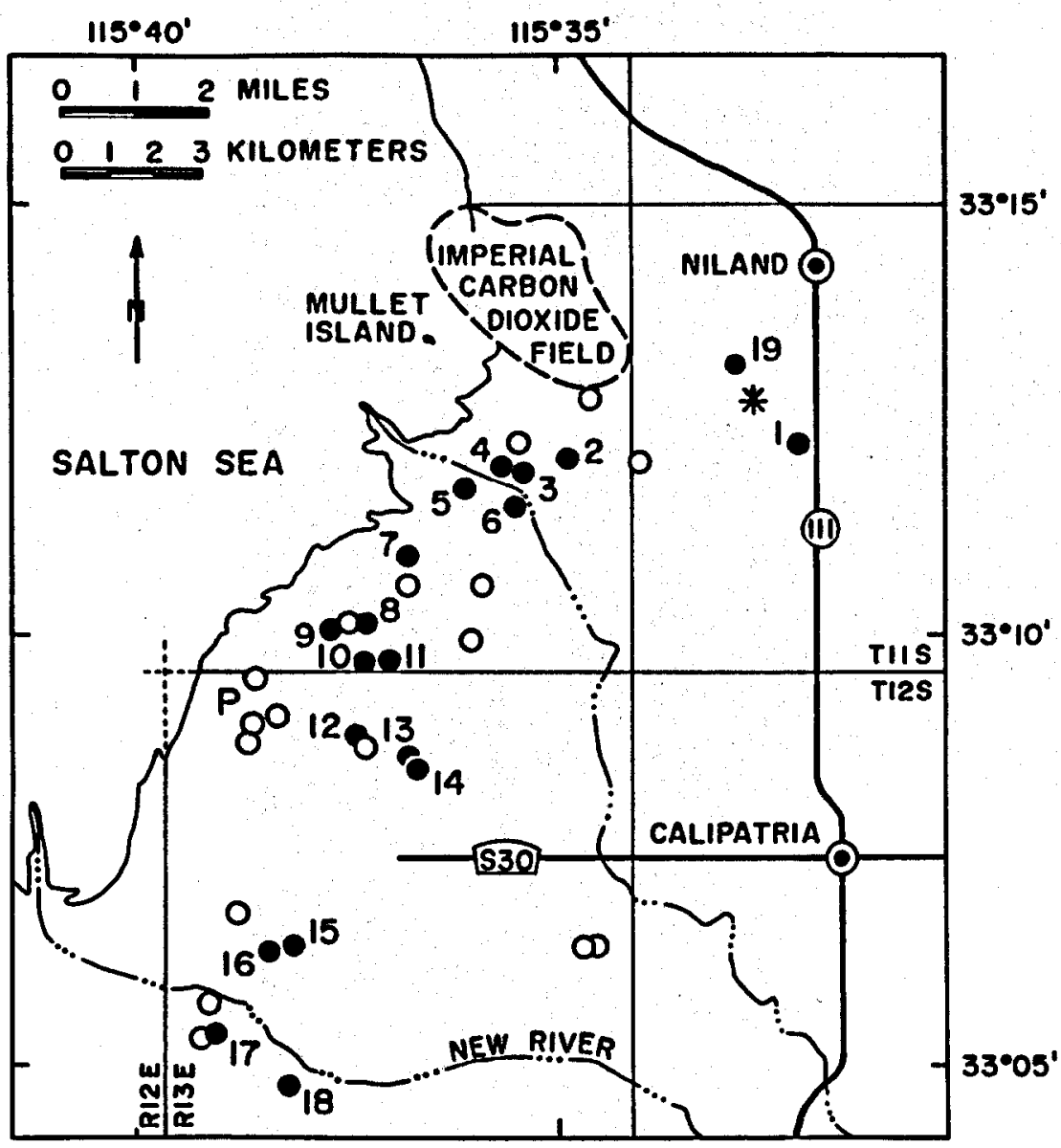

Figure 4-1. Location of Existing and Proposed Geothermal Hells in the Salton Sea and Mestmorland Geothermal Areas (Source - Muramoto, 1982).

$P$ Location of SCE power plant

- Geothermal wells for witch samples and/or log exist at UCR

O Other geothermal wells

* Proposed well Fee No. 7

\begin{tabular}{|c|c|}
\hline Number on Map & Mell Name \\
\hline 1 & Britz No. 3 \\
\hline 2 & River Ranch Mo. 1 \\
\hline 3 & Sportsman No. 1 \\
\hline 4 & I.I.D. No. 1 \\
\hline 5 & I.I.D. No. 2 \\
\hline 6 & State of California No. 1 \\
\hline 7 & Elmore No. 1 \\
\hline 8 & Magmamax No. 3 \\
\hline 9 & Magmamax No. 2 \\
\hline 10 & Magmamax No. 1 \\
\hline 11 & Wool sey No. 1 \\
\hline 12 & Sinclatr No. 4 \\
\hline 13 & Sinclair No. 1 \\
\hline 14 & Sinclatr No. 3 \\
\hline 15 & Landers No. 1 \\
\hline 16 & Landers No. 2 \\
\hline 17 & Dearborn Fams \\
\hline 18 & Kalin Farms \\
\hline 19 & Fee No. 1 \\
\hline
\end{tabular}



volcanoes and boiling mud pots were noted there by local inhabitants before the area was inundated by the rising lake, the modern Salton Sea, in 1906 (Lande, 1979). A small remnant area of mud pots is still visible about $4 \mathrm{~km}$ southeast of Mullet Island. The first attempt to exploit the geothermal resources of the SSGF was by the Pioneer Development Company which drilled three wells near Mullet Island in 1927 and 1928. The deepest reached $450 \mathrm{~m}$ and all three produced steam, boiling water and carbon dioxide, but not in sufficient quantity for commercial development (Lande, 1979).

The occurrence of $\mathrm{CO}_{2}$ led to further exploration drilling. In 1932 the Imperial carbon dioxide field, which produced commercially from 1933 to 1954, was discovered northeast of Mullet Island (Figure 4-1). Carbon dioxide, 98 percent pure, was produced from shallow sands 60 to $220 \mathrm{~m}$ below the surface and was used to produce dry ice for refrigeration. Abandonment of the field in 1954 came about by the development of modern refrigerated transport and was hastened by the rising waters of the lake, which inundated many of the wells (Lande, 1979).

In 1957 the Sinclair No. 1 well, an oil and gas prospect, was drilled to a depth of $1400 \mathrm{~m}$ and produced hot water and steam. This well scaled shut near the surface shortly afterwards. In 1961 the first well to be drilled expressily for steam, the Sportsman No, 1, was completed to $1500 \mathrm{~m}$, about $6 \mathrm{~km}$ northeast of Sinclair No. 1 , and was a good steam producer. In the next three years ten new geothermal wells were drilled in the vicinity, eight of which were good producers. These wells showed brine concentrations of up to 280,000 ppm TDS. Recognizing their potential, Morton Salt Company and Union 0il Company erected small pilot plants to experiment with brine handling. After several years of effort these facilities were abandoned as uneconomical.

After a period of inactivity, five new exploration wells were drilled in the SSGF during 1972 in a renewed search for alternate energy. A pilot brine-handling facility was jointly operated by the Department of Energy, San Diego Gas \& Electric Company, and Magma Power Company from about 1976 to 1979. Since that time more than a dozen new wells have been drilled, so that today more than 32 deep wells exist in the field (Figure 4-1). Apart from the 16 MWe power plant operated by Southern California Edison Company, plants of 50 MWe are being planned both by Magma Power Company and Parsons Engineering, Inc. for the near future. 


\subsubsection{Previous Opportunities for Studies of the SSGF}

Although publication of earth science-related work on the SSGF has been hindered by the limitations of dealing with proprietary data, there has been a significant number of published studies on this field. Most information was released in 1961-1968 during the first rush of enthusiasm for development when the novelty of the discoveries being made, coupled with the disappointing commercial results, created a climate where release of proprietary information was possible. Another fairly open situation for release of data occurred during the period 1974-1979 in connection with the test facilities which operated using brine from wells drilled by the Magma Power Company. Since that time, the major operators in the field have for corporate reasons kept proprietary the information on the newer wells. The latter now exceed the number drilled prior to 1979 (Figure 4-1).

\subsubsection{Some Previous Publications on the SSGF}

Five years after the initial report of discovery of this hot hypersaline geothermal system (White et al, 1963), a pioneering report on many aspects of its chemistry and thermodynamic properties appeared (Helgeson, 1968). This work was followed shortly thereafter by the first discussion of the active greenschist facies metamorphism going on within this system (Muffler and White, 1969). In 1974 the first attempt at understanding the subsurface geology using wireline logs was completed (Randall, 1974) and, about the same time, a useful compilation of water analyses and other data was published (Palmer, 1975). The associated volcanic rocks were first described in 1976 (Robinson et $a 1,1976$ ) and a more detailed study of metamorphic reactions in the field appeared in 1980 (McDowell and Elders, 1980). Finally, in 1982, a comprehensive review of the geological and geophysical characteristics of the SSGF, together with a simplified thermal model, appeared (Younker et al, 1982).

\subsection{GEOPHYSICAL ANOMALIES ASSOCIATED WITH THE FIELD}

The geophysical characteristics of the SSGF are well summarized in Younker et al (1982). As well as being a locus of high heat flow and high 
temperatures, the field is associated with positive gravity, magnetic and seismic velocity anomalies, low electrical resistivity, and high microseismicity.

\subsubsection{Gravity Anomalies}

In addition to the regionally-developed positive gravity anomaly along the axis of the Salton Trough, there are local gravity maxima associated with the geothermal fields within it. These gravity maxima have been attributed to either an increase in density of the sediments resulting from hydrothermal alteration, or the intrusion of dikes and sills into the sedimentary section, or both (Elders et al, 1972). By far the largest of these local maxima, centered on the Red Hill volcano in the SSGF (Figure 4-2), corresponds to a residual Bouguer anomaly of +23 milligals (Biehler, 1971) that is much too large to be due only to densification of sediments or presence of sporadic dikes and sills. Instead, the emplacement of a larger volume of mafic igneous rock seems required.

\subsubsection{Magnetic Anomalies}

The above hypothesis is supported by the magnetic signature of the SSGF. Magnetic surveys by Kelly and Soske (1936) and Griscom and Muffler (1971) reveal the presence of rocks with high magnetic susceptibility and remanent magnetization at fairly shallow depth (Figure 4-3). This compound positive magnetic anomaly is due only in part to the exposed rhyolite volcanoes. A long magnetic positive anomaly of 1000 gammas, 5 to $8 \mathrm{~km}$ wide, extends $28 \mathrm{~km}$ northwesterly from Calipatria over the southern part of the Salton Sea. Griscom and Muffler (1971) interpret this high as being caused by the presence of numerous concentrated dike swarms at depths greater than $2.25 \mathrm{~km}$. The two large elliptical magnetic anomalies (each marked by an $X$ in Figure 4-3) that are superimposed on this linear high represent magnetic masses that may be within $300 \mathrm{~m}$ of the surface. Griscom and Muffler (1971) further suggest that these elliptical anomalies are also due to clusters of dikes or other minor intrusions. Several small anomalies with amplitudes of 10 to 100 gammas (A to $D$ in Figure 4-3) are at least partly associated with the five rhyolite domes. 


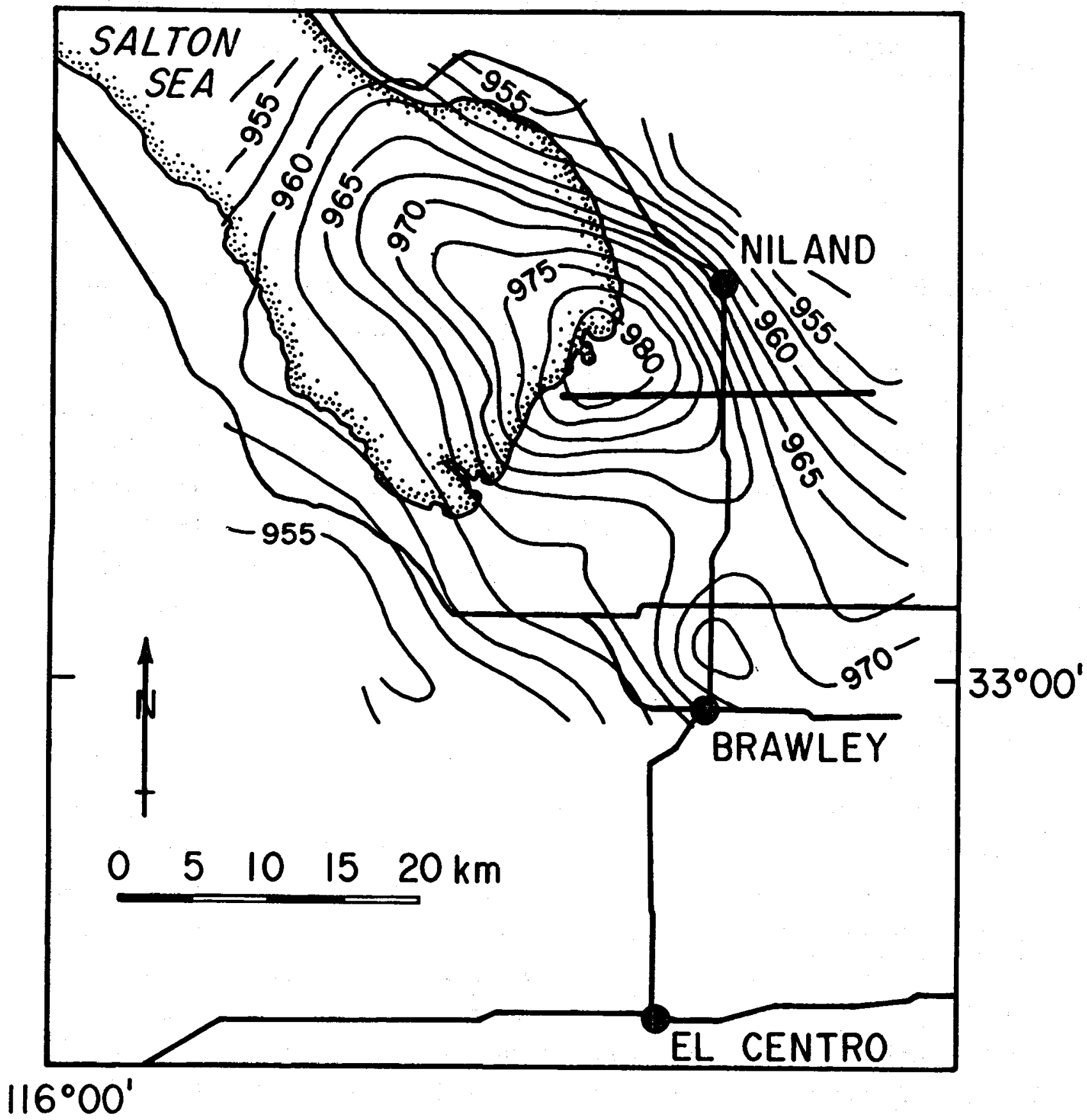

Figure 4-2. Bouguer Gravity Anomaly Map of the Area Around the Salton Sea Geothermal Field.

Heavy solid line shows the position of the seismic refraction profile shown in Figure 4-4. The contour interval is 2.5 mgals (Source - Biehler, 1971). 


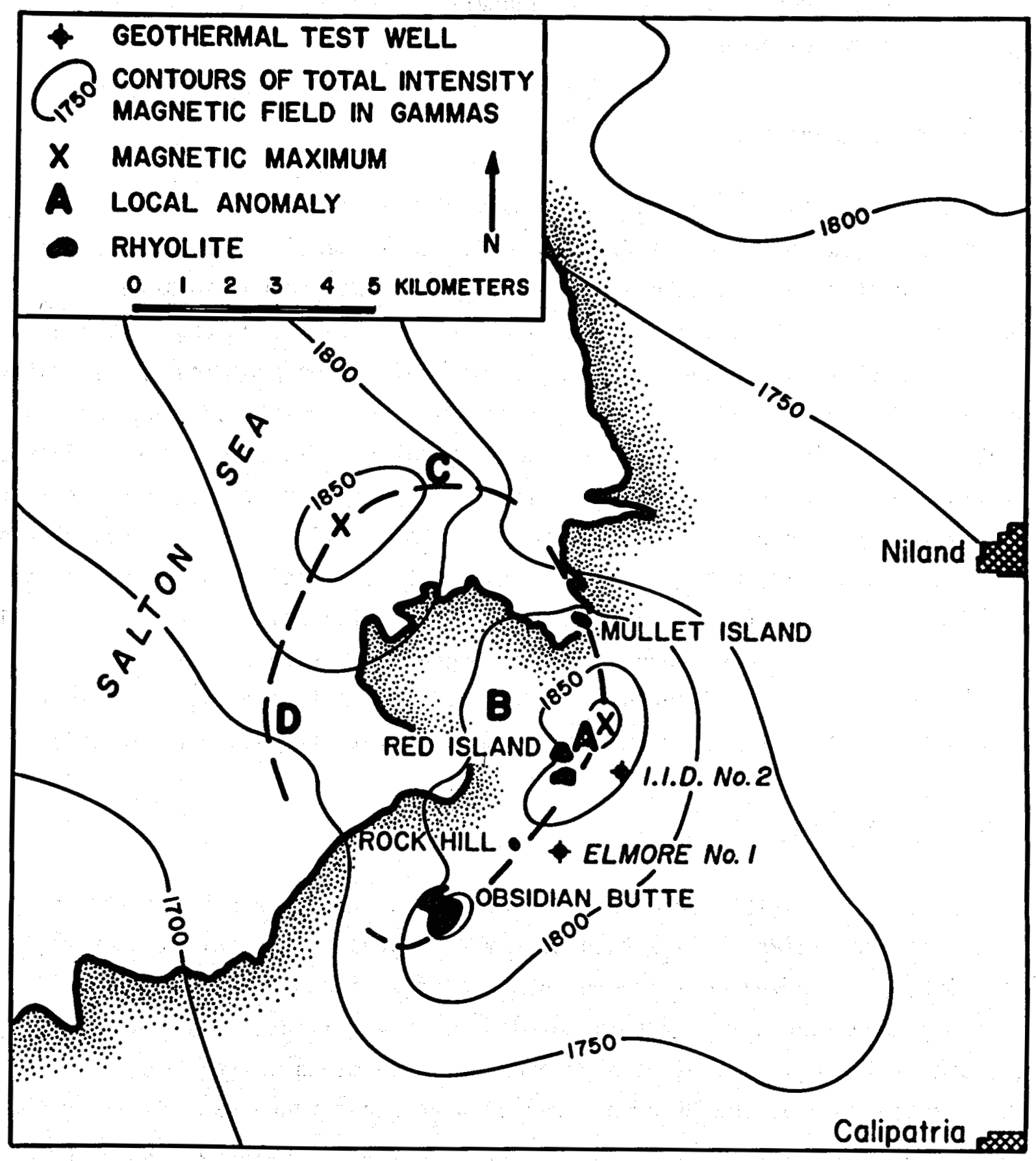

Figure 4-3. Map Showing the Salton Butte Volcanoes, Selected Geothermal Wells, Magnetic Anomalies, and Magnetic Contours.

A to $D$ are local magnetic anomalies of about 10 gammas. The "volcanic arc" is after Randall (1974) (Source - Robinson et al, 1976; After Griscom and Muffler, 1971). 
Randall (1974) suggested that these anomalies form an arcuate structure which he termed a "volcanic arc."

\subsubsection{Seismic Velocity}

The association of a gravity anomaly with a seismic travel-time anomaly in the SSGF (Savino et a1, 1977) was mentioned in section 3.3. A seismic refraction study of the SSGF and vicinity undertaken to obtain more information about this anomaly (Frith, 1978) involved four long-distance refraction shots and produced seven seismic refraction profiles. One profile, shown in Figure 4-4 and located in Figure 4-2, runs westwards from near the center of the field. Compared with the typical seismic velocities of Fuis et al (1982) for the central Imperial Valley, shown in Figure 3-5, a remarkably high velocity of $4.05 \mathrm{~km} / \mathrm{s}$ between only $0.8 \mathrm{~km}$ to $1.8 \mathrm{~km}$ depth is postulated. Those depths compare with depths of $3 \mathrm{~km}$ for this velocity in the center of the Imperial Valley (Figure 3-5). A "basement" with seismic velocity of 6.18 $\mathrm{km} / \mathrm{s}$ - a velocity higher than expected in granite basement - is also suggested. Reduction of porosity due to hydrothermal alteration and intrusion of basaltic material may explain these seismic velocity-depth observations.

\subsubsection{Resistivity}

Meidav et al (1976) used D.C. electrical currents as high as 200A to detect resistivities of less than $0.5 \Omega \mathrm{m}$ to depths of several kilometers in the SSGF. The survey consisted of 60 soundings with maximum separations of over $5 \mathrm{~km}$ and approximately $60 \mathrm{~km}$ of dipole survey lines. This survey detected a large volume of highly conductive sedimentary rock between the surface and $2 \mathrm{~km}$ depth. A broad area of high conductance extends along the axis of the Imperial Valley. The highest conductance coincides with the maxima of the gravity and magnetic anomalies in the SSGF, where the low resistivity coincides with high temperature and high salinity (Younker et al, 1982).

This concept was confirmed by the telluric soundings made by Humphreys (1978) in the vicinity of the SSGF. This method has the potential of determining resistivity to much greater depths than a D.C. resistivity survey. 


\section{PROPOSED WELL SITE}

W

(5)

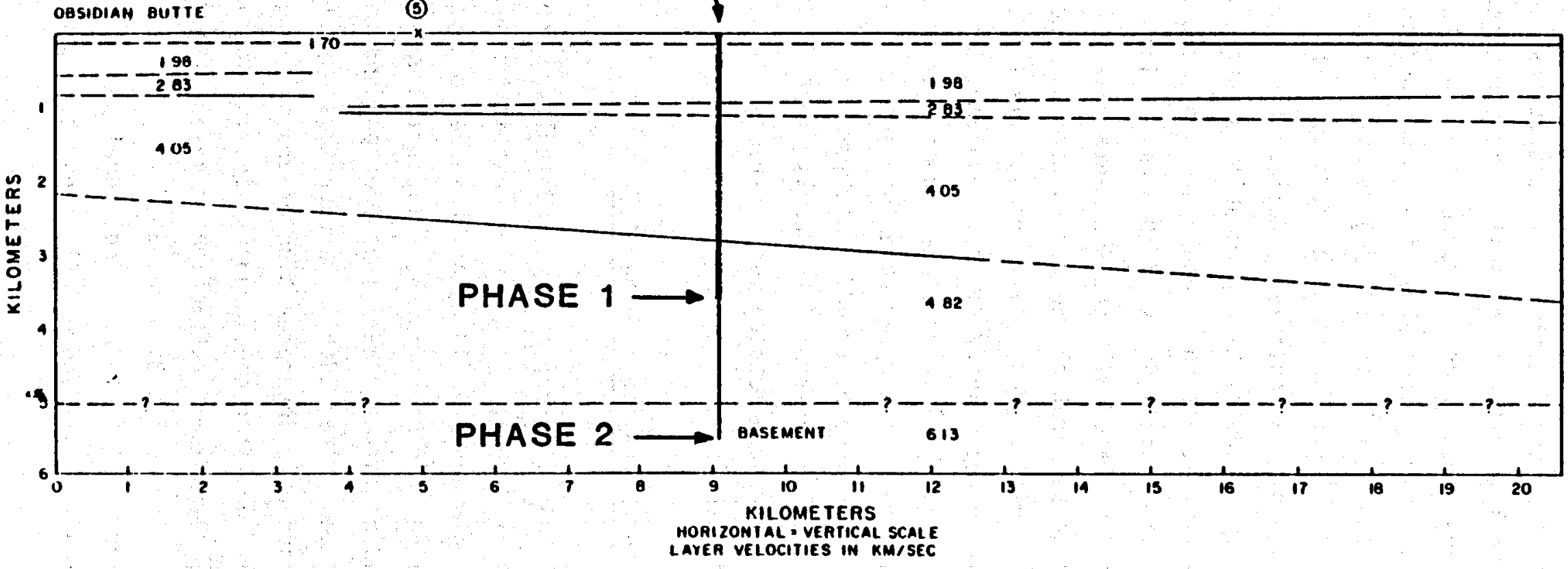

Figure 4-4. Seismic Refraction Profile from Obsidian Butte to the Alamo River.

The position of the profile is indicated on the gravity anomaly map (Figure

4-2). Velocities are in $\mathrm{km} / \mathrm{s}$. The location of a proposed very deep well, the

Fee No. 7 , is also shown (Source - Frith, 1978). 
Telluric signals were recorded at forty-two stations over a broad range of frequencies and analyzed at nine nominal periods ranging from 40 seconds to 1667 seconds. Thus a denser and larger coverage of the ragion, including the SSGF and the North Brawley geothermal field, was obtained. The results show a narrow trough of low resistivity ( $<2 \Omega \mathrm{m}$ ) running from the SSGF to the North Brawley field, more likely due to high salinity rather than high temperature alone. This trough of low resistivity follows the trend of the Brawley fault, which is presumably a zone of high permeability that permits communication of hypersaline pore fluids. At the south end of this trough is a near-surface resistivity low with resistivities of $<0.5 \Omega \mathrm{m}$. A large pronounced resistivity low $(<0.4 \Omega \mathrm{m})$ is associated with the sedimentary sequence in the SSGF due to a combination of high temperature and high salinity. The upper basement $6 \mathrm{~km}$ beneath the resistivity trough is very conductive for a presumed crystalline rock, usually having resistivity <15 sm. However, beneath the SSGF and North Brawley Geothermal Fields is a shallower upper basement with resistivities of $\leq 20 \mathrm{\Omega m}$. This more resistive upper basement beneath the geothermal fields implies lower connected porosity and hence lower content of brine than is observed in the drilled reservoir (Humphreys, 1978). This resistive zone could consist of indurated metasediments, fractured basaltic sheeted dikes, or a combination of both.

\subsubsection{Faulting and Seismicity in the SSGF}

Figure 4-5 shows a number of inferred faults which run NW-SE across the SSGF (Younker et al, 1982). To the southeast is the Brawley fault which was identified by Gilpin and Lee (1978) on the basis of hypocentral locations of microseisms. To the northeast is the Calipatria fault first postulated by Babcock (1971) using infrared aerial photography and the alignment of hot springs (Muffler and White, 1968). Between these two faults lies the Red Hill fault, first proposed by interpretation of ground magnetic data by Meidav and Furgerson (1972), and later confirmed by wireline log interpretations (Towse, 1975) and located by seismic refraction survey (Frith, 1978).

As mentioned in section 3.3, the SSGF is part of the Brawley seismic zone where seismic swarms are frequent. Individual swarms tend to occur at the ends of en echelon faults (Figure 4-5), consistent with the concept of these 
65

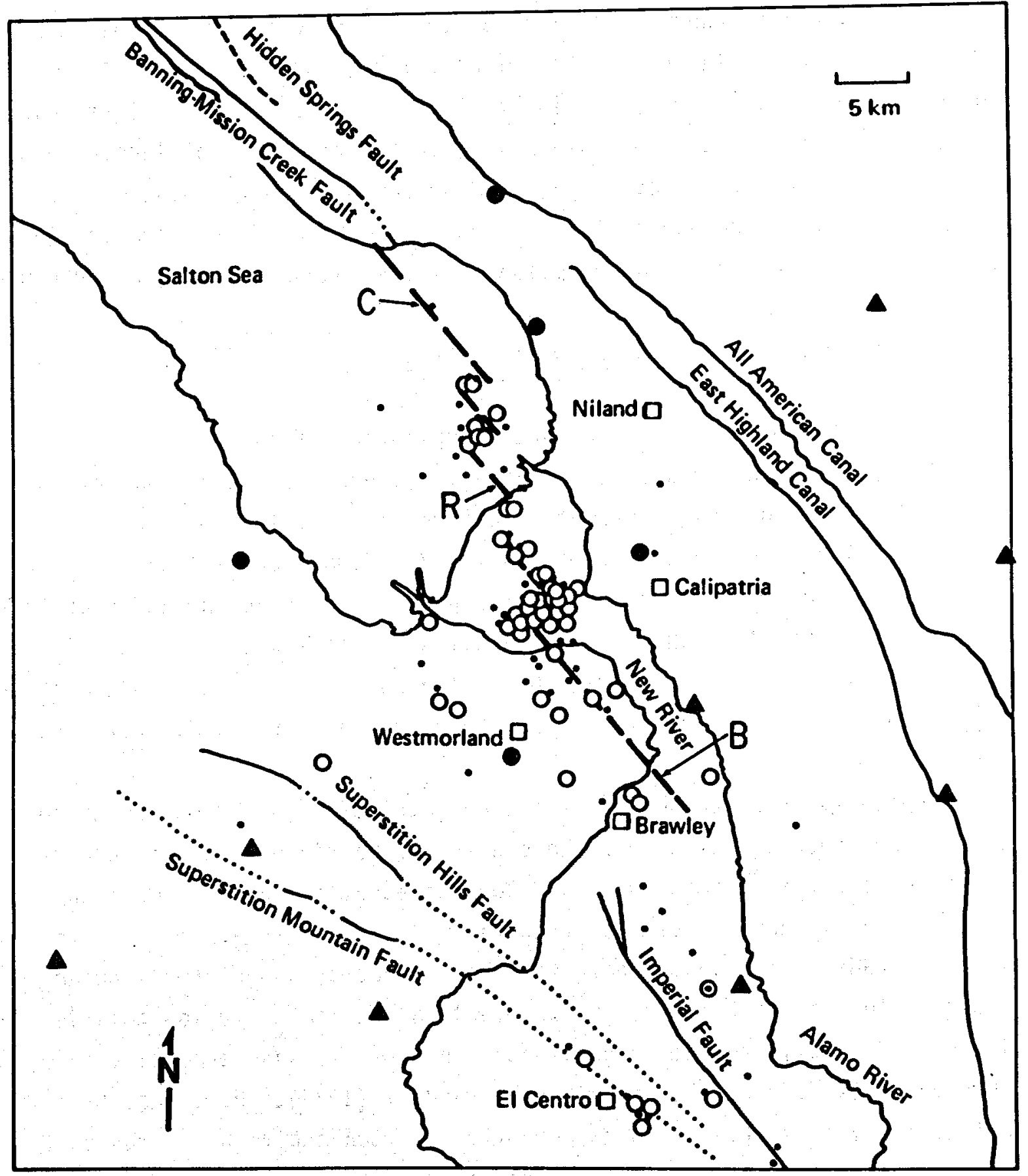

Figure 4-5. Location of Faults and Earthquake Epicenters in the Salton Sea Geothermal Field Area for the Period October 1, 1976 Through December 31, 1976.

The solid triangles and solid circles are seismograph stations in the Imperial Valley network. Open circles and dots are the observed epicenters. Tentative fault locations are shown in broken lines. $B=$ Brawley fault, $R=$ Red Hill fault, $C=$ Calipatria fault (Source - Schnapp and Fuis, 1977). 
being "pull-apart" zones. Two kinds of subsurface evidence suggest the mechanisms responsible for this swarm activity (section 3.3) - either dike intrusions or redistribution of interstitial fluid pressure. First, minor intrusions of rhyolite or diabase have been penetrated in at least six wells in the SSGF (Robinson et al, 1976), and presumably their emplacement was accompanied by earthquake activity. The second kind of evidence is the vein minerals which record repeated episodes of opening and sealing of fractures.

\subsubsection{Temperatures and Heat Flow Within the SSGF}

The most comprehensive published compilation of temperature information from the SSGF is in Younker et al (1982). Figure 4-6 shows their compilation of temperature profiles, apparently measured in equilibrium conditions, for 13 deep boreholes near the center of the field. Temperatures typically exceed $320 \mathrm{C}$ at $2 \mathrm{~km}$ depth, with the highest reported to date being $365 \mathrm{C}$ at $3100 \mathrm{~m}$ in the Elmore No. 1 borehole. The locations of the boreholes cited in Figure 4-6 are indicated in Figure 4-7, which also shows isotherms at $914 \mathrm{~m}$ (3000 ft) depth and contours of heat flux measured near the surface (McDowell and Elders, 1980).

Typically, gradients are very steep $(0.38 \mathrm{c} / \mathrm{m})$ in the upper 600 to $700 \mathrm{~m}$ of nine of these 13 wells near the center of the field, and are an order of magnitude lower at greater depths. Younker et al (1982) attribute this change to different mechanisms of heat transfer. They infer that the steep nearsurface gradient is due to conductive heat transfer associated with an impermeable clay-rich caprock which overlies the field. Below this is a zone, in the moderately- to well-consolidated interbedded sandstone-siltstonemudstone deltaic sequence described by Randall (1974), where heat transfer is primarily by convective flow of pore fluids. Convective heat transport in the section below the thermal cap is controlled by the thickness of the sandstone beds present. However, Younker et al (1982) also infer that flow is impeded by thin shale beds in this lower aquifer system. Thus large-scale vertical convection of fluid cannot take place.

The thermal cap in the center of the field does not exactly conform with the 1ithological caprock of Randall (1974). This thermal cap is inferred from the break in slope of temperature profiles. Younker et al (1982) plotted a 

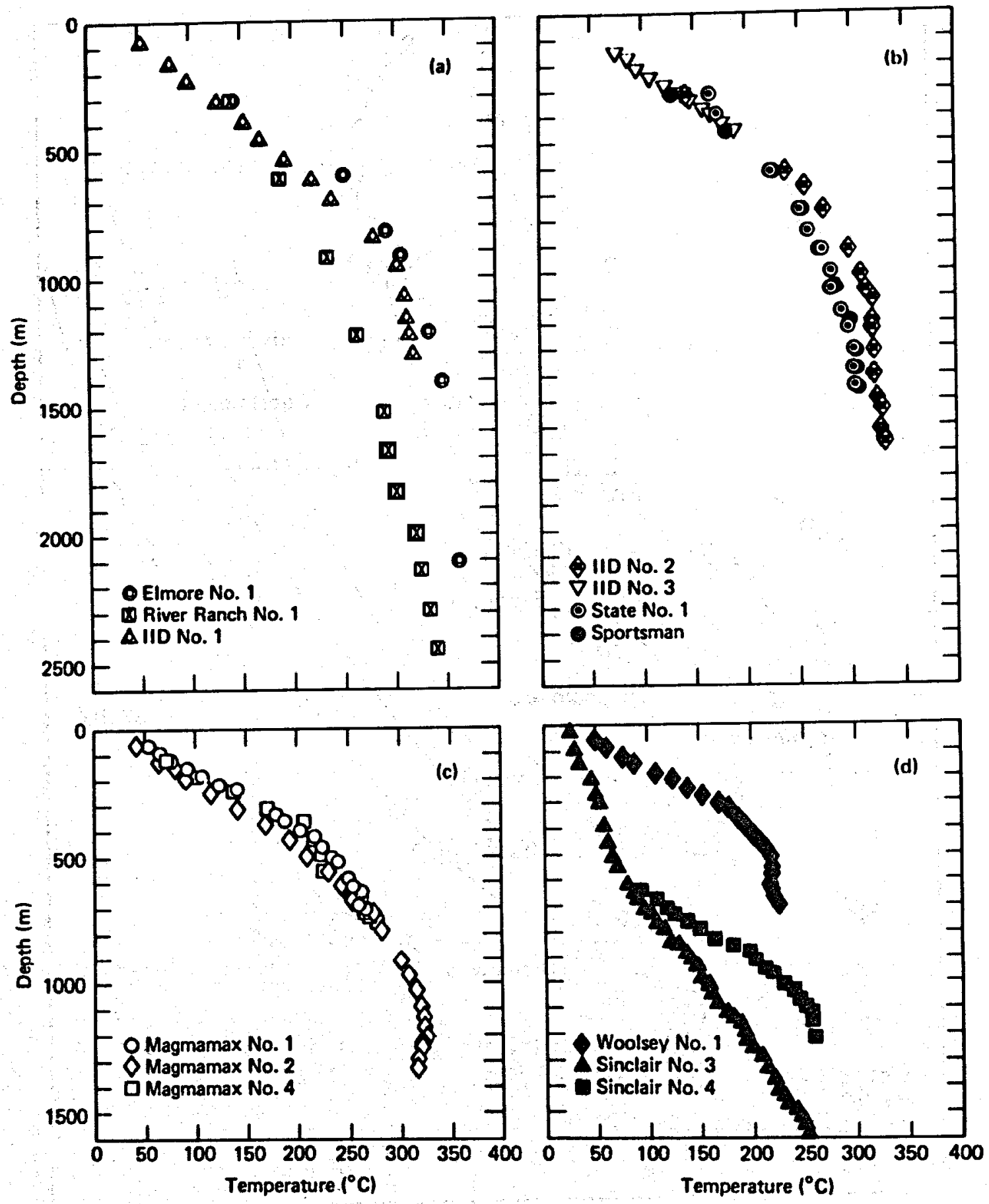

Figure 4-6. Equilibrium Temperature Profiles for 13 Wells in the Salton Sea Geothermal Field.

(A), (B) Wells from the northern part of the field. (C), (D) Welis from the southern part of the field. Data compilation by Younker et al, 1982 . 


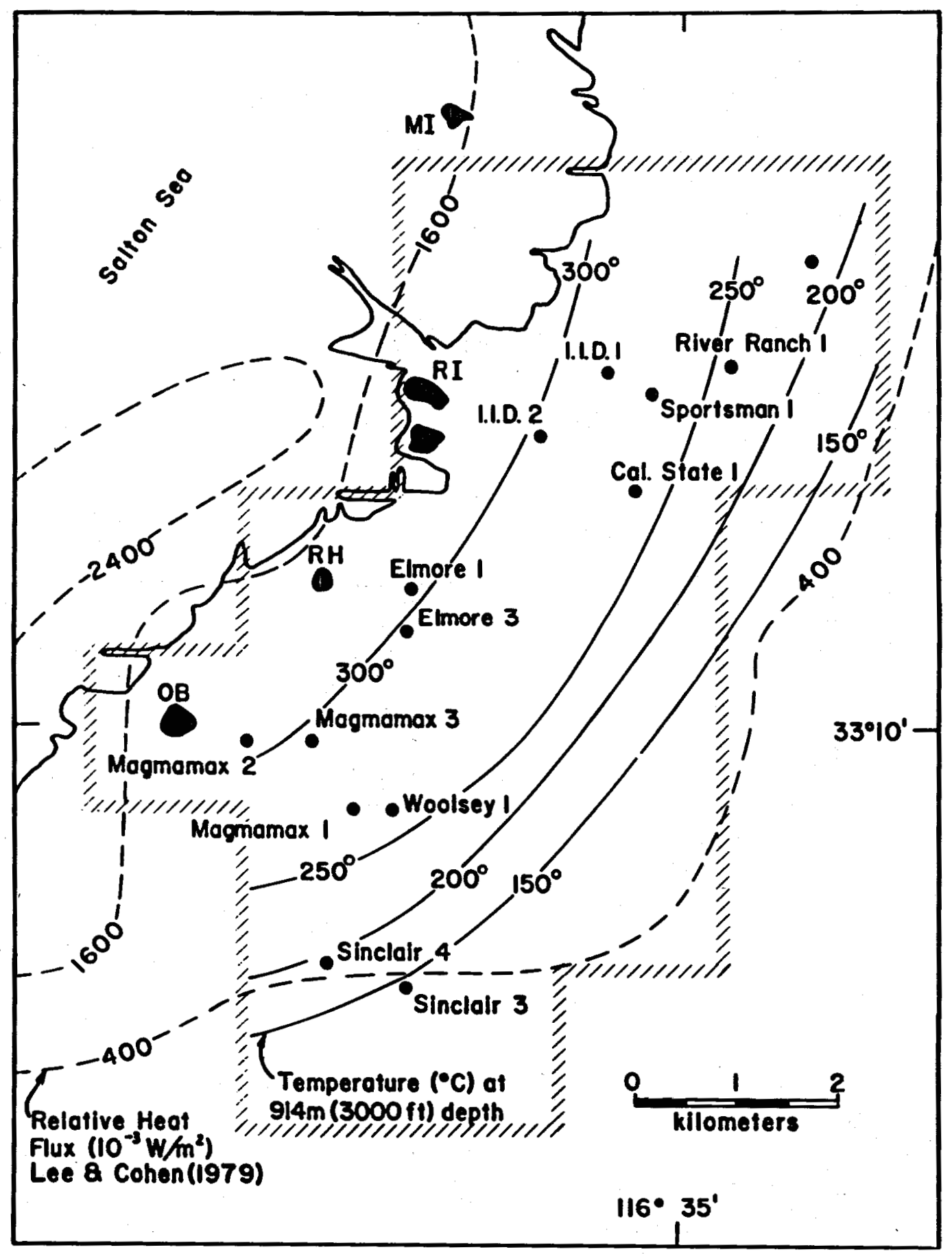

Figure 4-7. Location of Boreholes and Isotherms at $914 \mathrm{~m}(3000 \mathrm{ft})$ Depth in the Salton Sea Geothermal Field.

Solid lines $=$ temperature $(C)$, modified after Palmer (1975) and Randall (1974). Dashed lines = relative heat flux in $10^{-}$ watts $/ \mathrm{m}^{2}$ from Lee and Cohen (1979). Rhyolite extrusives: $O B=$ Obsidian'Butte; RH = Rock Hill; RI = Red Island; MI = Mullet Island. Hachured line $/ / / /=$ outline of the Salton Sea KGRA (Source - McDowell and Elders, 1980). 
north-south cross section across the field that compared the reservoir character with the thickness of the thermal cap (Figure 4-8). The base of the thermal cap is often within a zone containing greater than 20 percent sand (Towse and Palmer, 1975), and the first appearance of high reservoir quality also appears at the base of the thermal caprock. These observations support the authors' interpretation that the dominant controls on heat transport are thick sandstone beds and intervening shales. Fracture permeability of the shales, however, may be locally significant (Younker et al, 1982).

Morse and Thorsen (1978), on the basis of reservoir engineering tests, calculate that the reservoir has horizontal permeabilities of 100 to $500 \mathrm{md}$ while vertical permeabilities across shale layers are only 0.1 to $1.0 \mathrm{md}$. Another factor precluding large scale vertical convection is the density profile of the brines. Helgeson (1968) showed that the hydrostatic pressure-versus-depth profile in the field is almost constant at $0.098 \mathrm{bars} / \mathrm{m}$, consistent with a fluid of constant density of $1 \mathrm{~g} / \mathrm{cm}^{3}$. The effect of increasing salinity with depth balances the effect of increasing temperature, tending to keep the density uniform with depth.

Younker et al (1982) thus state that heat transfer mechanisms in the SSGF can be modeled as a three layer system. These are (1) an impermeable thermal cap; (2) a layer within the thermal cap with higher thermal conductivity sands producing a lower temperature gradient; and (3) a zone of low thermal gradients consistent with small-scale cellular convection limited to individual sand bodies.

Younker et al (1982) divided the field into three distinct areas. First, there is a central zone with nearly constant vertical conductive heat flow having a thermal cap with gradients of $0.4 \mathrm{c} / \mathrm{m}$ and overlying a nearly isothermal zone extending to $2000 \mathrm{~m}$ depth. Next is an intermediate region with low near-surface gradient and an increasing temperature gradient at greater depths. Finally, to the southeast is an outer zone with nearly uniform and lower shallow gradient of $0.1 \mathrm{c} / \mathrm{m}$, similar to the normal regional values. This overall pattern is consistent with a large-scale horizontal flow in layer three which transfers heat from the area of the volcanic domes southeast towards the margins of the field.

To date the only published preproduction reservoir models of the SSGF have been rudimentary. Schroeder (1976) analyzed the sparse data available 


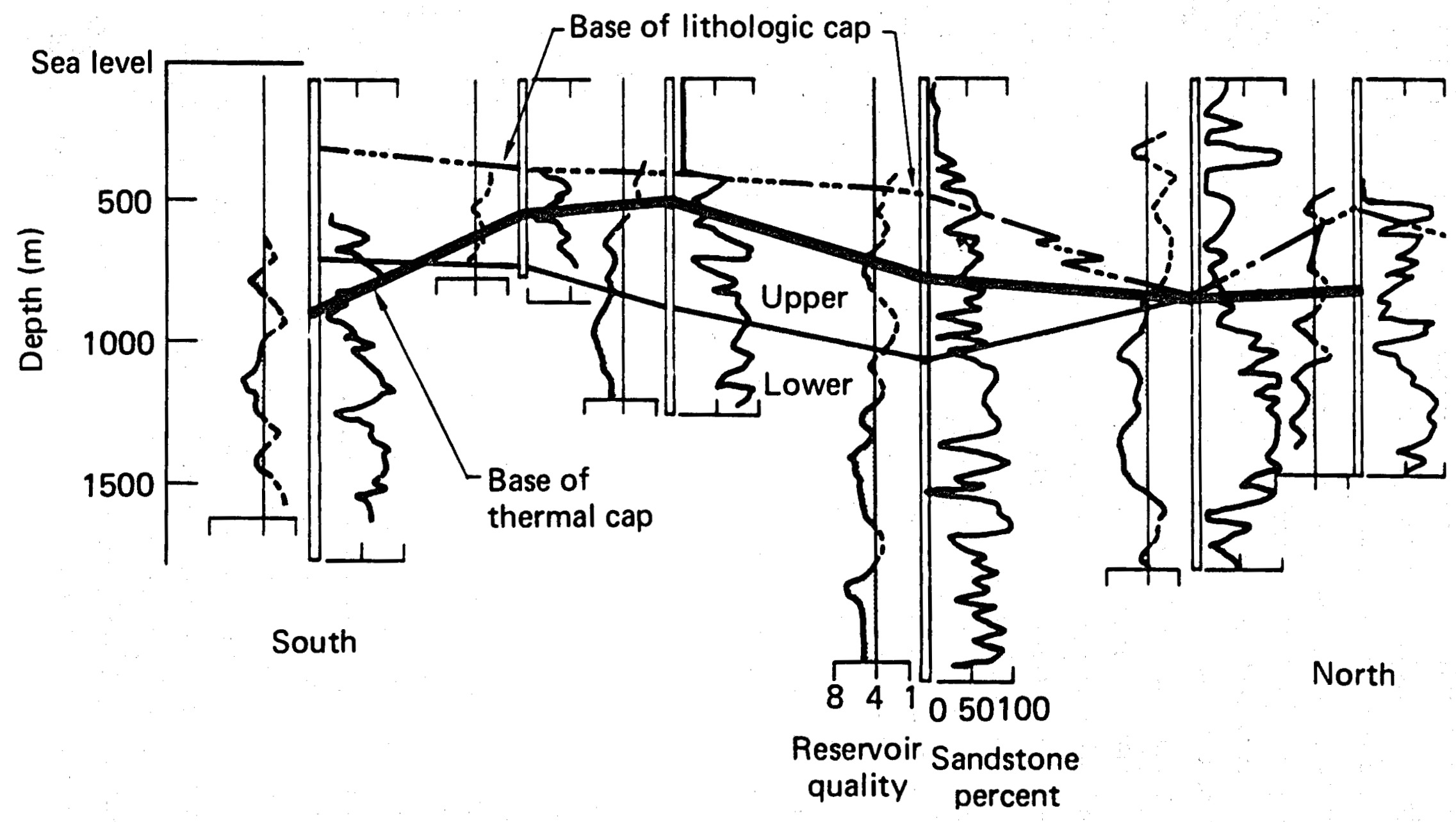

Figure 4-8. North-south Section Across the Salton Sea Geothermal Field Showing the Thermal Lithologic Caps.

Sandstone percentage, a subjective measure of reservoir quality (Towse, 1975), and the depth to the base of the thermal cap are shown for six wells. From south to north, the wells are Sinclair \#4, Woolsey \#1, Magmamax \#3, Elmore \#1, I.I.D. \#2, and Sportsman \#1 (Source - Younker et al, 1982). 
from drill stem test records in wells Magmamax No. 1 and Woolsey No. 1 and concluded that the upper reservoir between the caprock and the first major shale break had a horizontal permeability of $500 \mathrm{md}$ in sands with porosity of 30 percent. Later Riney et al (1978) performed a two dimensional simulation of the portion of the reservoir around Magmamax 1, 2, and 3 and Woolsey No. 1. They considered a three-layer model of caprock and upper and lower reservoirs, with the latter separated by a leaky barrier. Noting that temperatures at the southeast end of a horizontal section through the reservoir are lower than at the northwest end, Riney et al (1978) suggest that there is a lengthwise pressure drive which should cause influx of $\sim 50 \mathrm{C}$ ground water from the southeast, i.e., in a direction opposed to the flow of hot water proposed by Younker et al (1982). This "cold" water flow would cool the upper reservoir if hot brine infusion from the lower reservoir were completely precluded. This simulation showed that the upper reservoir in this portion of the SSGF appears capable of supplying brine for a 50 Mwe net electric plant from the upper aquifer with very little decline in temperature over 30-40 years. This simulation was based on very limited data, however, and assumed a number of unrealistic boundary conditions, e.g., that the brine has uniform salinity of 25 wt percent, and that the Brawley and Red Hill faults parallel to the modeled two dimensional section are boundaries of no flow.

Figure 4-1 shows additional deep boreholes which were not included in the compllation of Younker et al (1982). Temperature logs have been released for some of these, including wells in the Westmorland area $7-8 \mathrm{~km}$ south of the center of the field and the Britz No. 3 well near Niland, $6-7 \mathrm{~km}$ to the northeast of the main part of the field. Figure 4-9 shows the temperature gradients from wells in the Westmorland part of the SSGF. These four production wells have essentially linear temperature gradients of approximately $0.087 \mathrm{c} / \mathrm{m}$ for the full range of depth, yielding temperatures of 188 to $217 \mathrm{C}$ at $2000 \mathrm{~m}$ and a maximum of $262 \mathrm{C}$ measured at $2350 \mathrm{~m}$. These linear gradients imply that the vertical heat transfer is conductive. Brines produced from this part of the SSGF had in each case total dissolved solids of less than $70,000 \mathrm{ppm}$, similar to deep brines el sewhere in the Imperial valley. The salinity is even less in the most southerly of the Westmorland boreholes. Based upon this fact and on the variations in $\delta^{18} 0$, which increase from south to north, 01 son and Matlick (1978) proposed that this systematic variation 


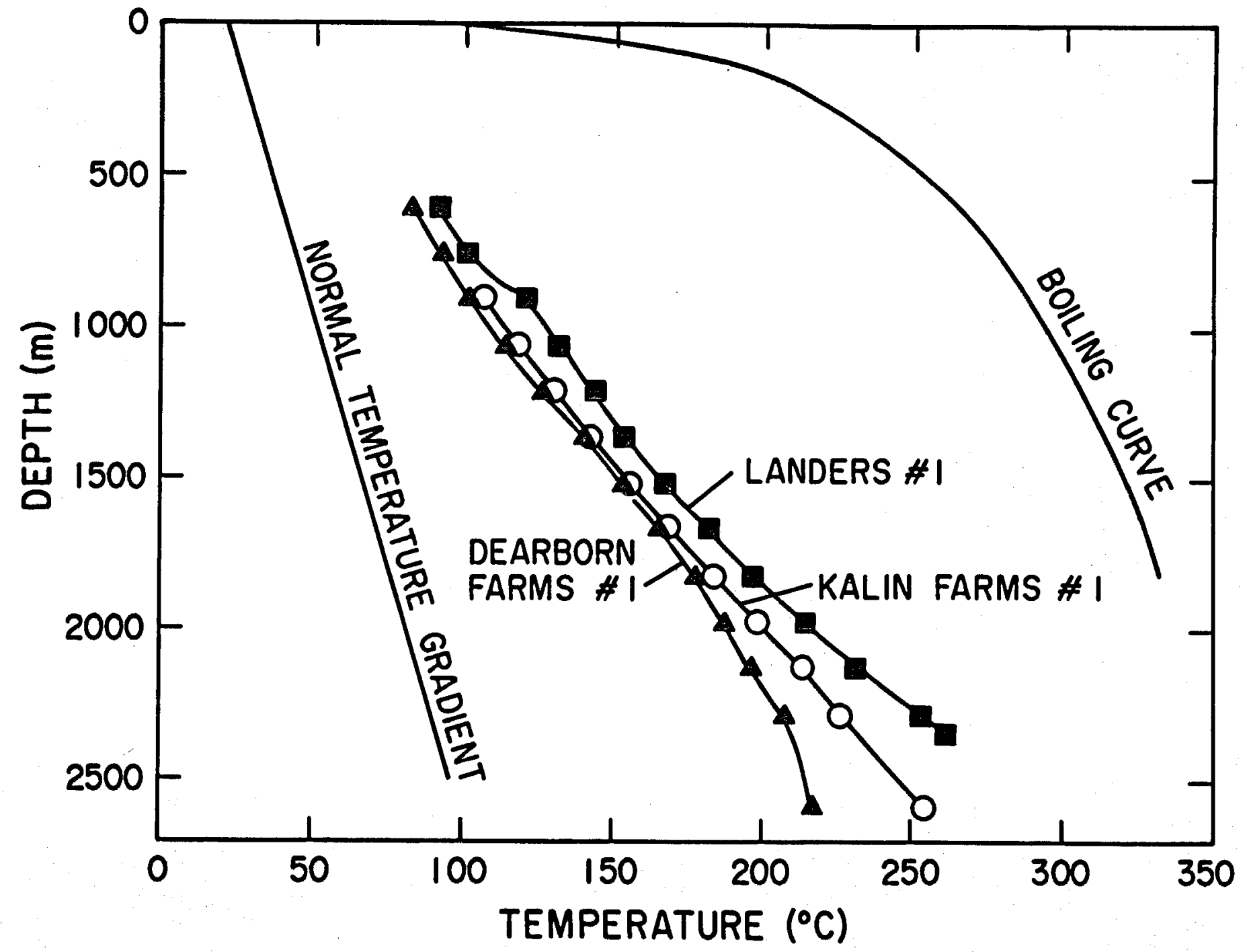

Figure 4-9. Temperature Profiles of Westmorland Geothermal Wells.

A "normal" gradient of $30^{\circ} \mathrm{C} / \mathrm{km}$, and the boiling curve for pure water are shown for reference (Source - 01 son and Matlick, 1978). 
requires lateral subsurface flow of cooler more dilute brine from south to north.

Figure 4-10 shows the temperature gradient in the Britz No. 3 well, the most northeasterly of the wells shown in Figure 4-1. This well had a bottom hole temperature of $285 \mathrm{C}$ at $2800 \mathrm{~m}$. Britz No. 3 also exhibits a linear temperature gradient of $0.087 \mathrm{C} / \mathrm{m}$, suggestive of conductive vertical heat flow. For comparison, the gradient for the borehole Elmore No. 1, the hottest in the SSGF, is also shown. Brines from Britz No. 3 had salinities of $\leq 250,000 \mathrm{mg} / 1$. These wells near Niland have in common with those near Westmorland the fact that their shale/sand ratio is much higher than wells such as Elmore No. 1 and others in the center of the field. Thus their vertical permeability is apparently too low to permit development of extensive vertical convection. An overall synthesis and comprehensive modelling of the temperature data for the SSGF must await future work.

\subsection{BRINE CHEMISTRY IN THE SSGF}

The brines in the SSGF are concentrated sodium, calcium, potassium chloride solutions containing some of the highest concentrations of dissolved metals known in nature. These brines are comparable in their heavy metal concentrations to the unusually high salinity brines which have been produced from geothermal wells in the Cheleken anticline, on the east shore of the Caspian Sea (Lebedev, 1973), and from the enclosed deeps in the Red Sea (Degens and Ross, 1969). White (1981) calculated that the estimated volume of $116 \mathrm{~km}^{3}$ of the SSGF (noted in section 4.1.1: 1.e., depth of $3 \mathrm{~km}$, mean reservoir temperature $330 \mathrm{C}$, and assumed porosity 10 percent) contained the following valuable elements in metric tonnes:

$$
\begin{array}{lll}
\text { Zn } 5 \times 10^{6} ; & \text { Pb } 9 \times 10^{5} ; \\
\text { As } 1.2 \times 10^{5} ; & \text { Cu } 6 \times 10^{4} ; \\
\text { Cd } 2 \times 10^{4} ; & \text { Ag } 1 \times 10^{4} ; \\
\text { K } 1.7 \times 10^{8} ; & \text { Li } 2.2 \times 10^{6} ; \\
\text { B } 4 \times 10^{6} ; & \text { Cs } 1.5 \times 10^{5} ; \\
\text { T1 } 1.4 \times 10^{4} ; & \text { Mn } 1.6 \times 10^{6} ;
\end{array}
$$

If, as seems apparent from the work of Humphreys (1978), these high salinity brines extend from the SSGF to the Brawley Geothermal Field, then the volume 


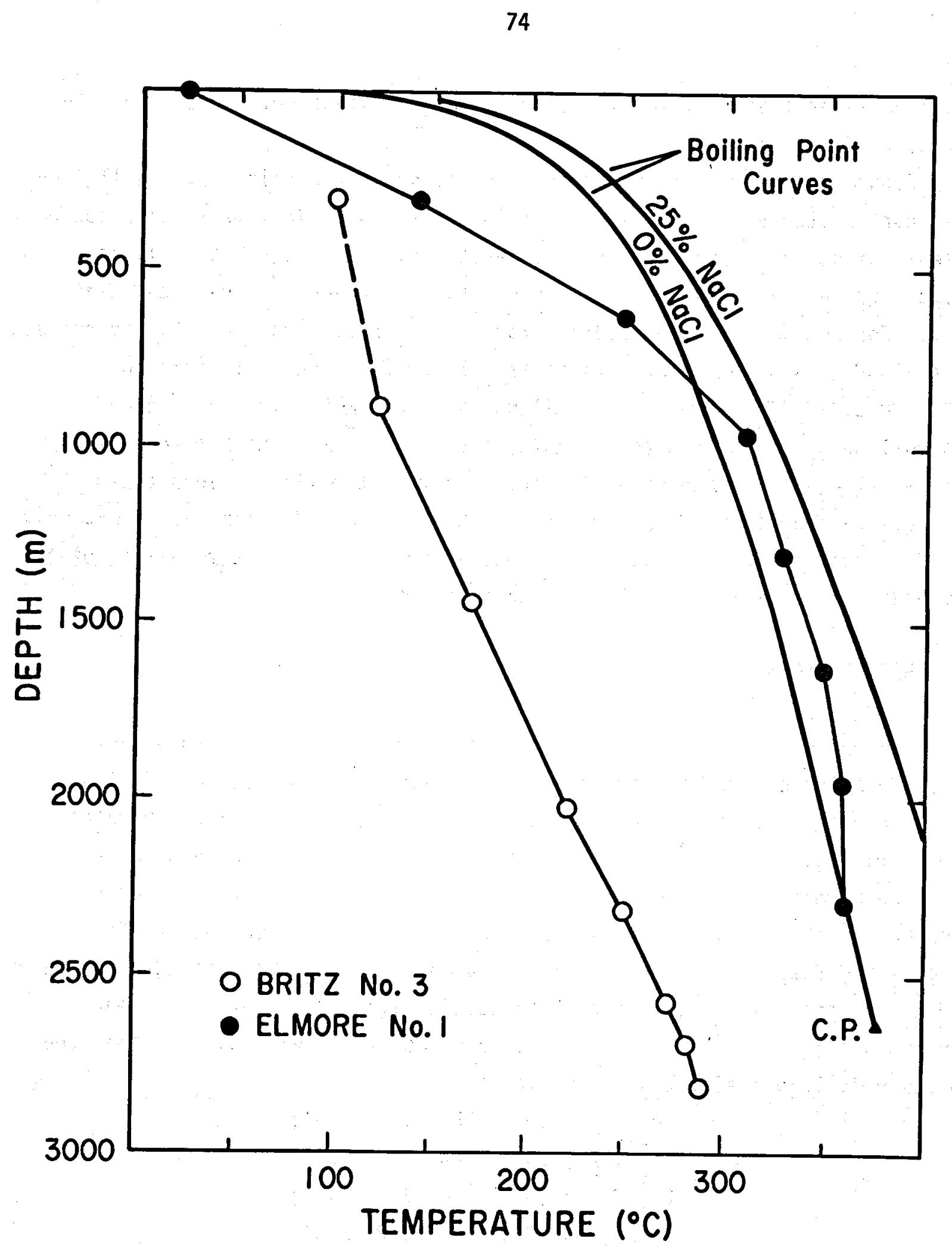

Figure 4-10. Equilibrium Temperature Logs for Elmore No. 1 and Britz No. 3 Wells, Together with the Boiling Point Curves for Pure Water and a $25 \% \mathrm{NaCl}$ Solution.

$C P=$ critical point of pure water (Source - Ellis and Mahon, 1977). 
of accessible concentrated brines could be an order of magnitude greater than the estimate made by White.

\subsubsection{Brine Chemistry}

The chemistry of SSGF brines was first reported by White et al (1963). Later Craig (1966) compared their chemistry and isotopic ratios with brines from the Red Sea. Detailed analyses of brines from the early wells were then published by Helgeson (1968), Skinner et al (1967), and White (1968). Later involvement of staff of Lawrence Livermore National Laboratory in studies of wells supplying the San Diego Gas and Electric Geothermal Test Loop Experiment Factlity, from 1975-1978, led to a compilation of data on these wells (Palmer, 1975) and studies of various aspects of the brine chemistry (Harrar et al, 1979; Austin et a1, 1977; Maimoni, 1982).

Table 4-1 summarizes the chemical compositions of wells drilled before 1975 in the central portion of the SSGF (well locations appear in Figure 4-1). Geothermal brines are notoriously difficult to sample. At the well-head they consist of a multiphase mixture of condensible and uncondensible gas, liquid, and suspended solids. Normally the greatest problem is to evaluate the steam loss due to boiling before a sample is taken. Thus there may be sampling errors as well as possible analytical errors in reported values. Additional errors are introduced due to reactions within the brines on quenching to room temperature, e.g., the precipitation of barium sulfate before sample analysis. A further problem is that the well-head compositions vary with changes in flow rates, possibly due to tapping different aquifers or fracture systems at different well-head pressures. Table 4-2 shows some changes in brine composition during production of the well Magmamax No. 1 over a two month period in 1976 (Maimoni, 1982).

Salinity varies both vertically in a given well and horizontally from well to well. For example, an analysis reported from Fee No. 1 gave a total concentration of $250,000 \mathrm{ppm}$ TDS, whereas two samples from Britz №. 3, the well closest to Fee No. 1, are reported as 116,000 and 133,772 ppm TDS from zones at roughly the same depths. Presumably these differences came from mixing different fluids tapped from different aquifers. Certainly wells in the Westmorland part of the field (Figure 4-1) have penetrated a much lower 
Table 4-1. Chemical Compositions of Salton Sea Brines

Wootsey No. I

Palmer (1975)

State of Calif. (maximum ppm

I.I.D. No. 1 I.I.D. No. 1 I.I.D. No. 2 No. 1 values from Magmamax No. 1 Skinner et al (1967)* White (1968)* Helgeson (1968)* Helgeson (1968)* Magma Power Co.)t Palmer (1975)t

$\mathrm{Zn}$
$\mathrm{Pb}$
$\mathrm{Cu}$
$\mathrm{Ag}$
$\mathrm{Fe}$
$\mathrm{Mn}$
$\mathrm{Na}$
$\mathrm{Ca}$
$\mathrm{K}$
$\mathrm{Li}$
$\mathrm{CI}$
$\mathrm{SO}$
Sulfide S
Silica
pH
TDS
S.G.
BHT

790
84
8
0.8
2,090
1,560
50,400
28,000
17,500
215
155,000
5
16
400
5.2
258,360
--
$316 \mathrm{C}$

$\begin{array}{cc}540 & 500 \\ 102 & 80 \\ 8 & 3 \\ 1.4 & 2 \\ 2,290 & 2,000 \\ 1,400 & 1,370 \\ 50,400 & 53,000 \\ 28,000 & 27,800 \\ 17,500 & 16,500 \\ 215 & 210 \\ 155,000 & 155,000 \\ 5.4 & 30(\text { Total S) } \\ 16 & 400 \\ 400 & 4.64 \\ 5.2 & 258,769 \\ \sim 250,000 & \cdots \\ -- & 332 \mathrm{C} \\ 340 \mathrm{C} & \end{array}$

$\begin{array}{r}500 \\ 80 \\ 2 \\ <1 \\ 1,200 \\ 950 \\ 47,800 \\ 21,200 \\ 14,000 \\ 180 \\ 127,000 \\ -- \\ 30 \\ -.- \\ -- \\ 219,500 \\ \cdots- \\ \hline 305 \mathrm{C}\end{array}$

$\ldots$
$\cdots$
$\cdots$
$\cdots$
244
488
49,729
12,658
6,510
90
83,183
$\cdots$
$\cdots$
181
6.25
151,237
1.106
$238 \mathrm{C}$

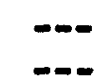$$
\text { -- }
$$$$
93
$$$$
93
$$$$
52,500
$$$$
25,000
$$$$
5,000
$$$$
\text { -.. }
$$$$
--
$$$$
--
$$$$
500
$$$$
6.65
$$$$
>100,000
$$

Al1 compositions are given in ppm unless otherwise noted. Not all analyzed constituents are listed.

*Known to be corrected for steam loss tNot known if corrected for steam loss TDS - Total Dissolved Solids in ppm by wt
S.G. - Specific Gravity at 20 to 25 C

BHT - Bottom Hole Temperature

-.. - Not reported 
Table 4-1 (cont.). Chemical Compositions of Salton Sea Brines

\begin{tabular}{|c|c|c|c|c|}
\hline & $\begin{array}{c}\text { Magmamax No. } 1 \\
\text { Needham et al (1980) } \\
\text { (Average of Jan. } \\
1977 \text { tests) }\end{array}$ & $\begin{array}{l}\text { Wool sey No. } 1 \\
\text { Needham et al (1980) } \\
\text { Average chemical } \\
\text { analyses Feb. 1977) }\end{array}$ & $\begin{array}{c}\text { Sportsman No. } 1 \\
\text { Palmer }(1975) \mathrm{f} \\
\end{array}$ & $\begin{array}{l}\text { Sinclair No. } 4 \\
\text { Palmer (1975)t }\end{array}$ \\
\hline $\begin{array}{l}\mathrm{Zn} \\
\mathrm{Pb} \\
\mathrm{Cu} \\
\mathrm{Ag} \\
\mathrm{Fe} \\
\mathrm{Mn} \\
\mathrm{Na} \\
\mathrm{Ca} \\
\mathrm{K} \\
\mathrm{Li} \\
\mathrm{Cl} \\
\text { SO } \\
\text { Sulfide S } \\
\text { Silica } \\
\text { pH } \\
\text { TDS } \\
\text { S.G. } \\
\text { BHT }\end{array}$ & 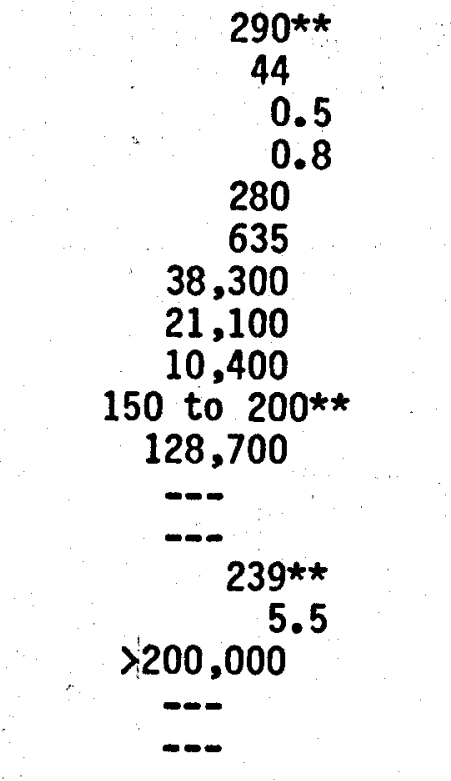 & $\begin{array}{c}-. \\
\cdots \\
\cdots \\
\cdots \\
40,000 \\
16,700 \\
9,100 \\
140 \\
99,000 \\
-- \\
-\cdots \\
- \\
>150,000 \\
-\cdots \\
200 \mathrm{C}\end{array}$ & $\begin{array}{c}\cdots \\
\cdots \\
\cdots \\
\cdots, 200 \\
70,000 \\
34,470 \\
24,000 \\
150 \\
201,757 \\
34 \\
-\ldots \quad 5 \\
4.82 \text { to } 6.10 \\
334,987 \\
1.207 \\
310 \mathrm{C}\end{array}$ & $\begin{array}{r}600 \\
60 \\
3 \\
1 \\
1,300 \\
1,700 \\
78,000 \\
37,735 \\
20,690 \\
400 \\
210,700 \\
75 \\
-\ldots \\
625 \\
5.0 \\
387,500 \\
-. \\
260 \mathrm{C}\end{array}$ \\
\hline
\end{tabular}

**Concentrations from samplings in 1976 
Table 4-2. Changes in Brines Composition During Production of Magmamax No. 1

\begin{tabular}{|c|c|c|c|c|c|}
\hline & \multicolumn{5}{|c|}{ Date Taken (1976) } \\
\hline & $6 / 29$ & $6 / 30$ & $8 / 08$ & $8 / 10$ & $8 / 10$ \\
\hline Temperature $\left({ }^{\circ} \mathrm{C}\right)$ & 200 & 214 & 230 & 215 & 215 \\
\hline Pressure (psig) & 225 & 240 & 320 & 235 & 235 \\
\hline \multicolumn{6}{|c|}{ Composition (ppm by weight) } \\
\hline Lithium & -- & -- & 128 & 135 & 141 \\
\hline Sodium & 40900 & 42100 & 41200 & 42700 & 42000 \\
\hline Silicon & 181 & 187 & 190 & 200 & 202 \\
\hline Potassium & 6900 & 7000 & 6600 & 6500 & 8600 \\
\hline Iron & 202 & 161 & 199 & 180 & 256 \\
\hline Copper & 1 & 1 & 1 & 1 & 1 \\
\hline Rubidium & -- & --- & --- & --- & 64 \\
\hline Barium & 54 & 85 & 115 & 118 & 118 \\
\hline Magnesium & 125 & 125 & 95 & 99 & 80 \\
\hline Zinc & 188 & 183 & 275 & 285 & 361 \\
\hline Strontium & --- & $\cdots$ & 360 & 373 & 388 \\
\hline Tin & 23 & 23 & -- & -- & -- \\
\hline Al uminum & -- & -- & -- & 1 & 1 \\
\hline Chlorine & 101000 & 105000 & 111000 & 112000 & 121000 \\
\hline Calcium & 17400 & 16900 & 17900 & 18200 & 20000 \\
\hline Manganese & 502 & 494 & 565 & 570 & 690 \\
\hline Antimony & 4 & 4 & -- & -- & -- \\
\hline Lead & 22 & 22 & 60 & 59 & 78 \\
\hline $\mathrm{NH}_{3}$ & --- & $\cdots$ & --- & -- & $30-60$ \\
\hline $\mathrm{CO}_{2}$ & --- & $\cdots$ & -- & $\cdots$ & $1-2(w t \%)$ \\
\hline $\mathrm{H}_{2} \mathrm{~S}$ & -- & -- & --- & -- & $10-30$ \\
\hline pH & -- & 5.7 & 5.8 & 6.1 & 5.2 \\
\hline \multicolumn{6}{|c|}{ Oxidation-reduction potential } \\
\hline$\left(m V\right.$ vs. $\left.H_{2}\right)$ & -- & -- & 192 & 177 & 237 \\
\hline Density $\left(\mathrm{g} / \mathrm{cm}^{2}\right)$ & 1.12 & 1.12 & 1.13 & 1.14 & 1.15 \\
\hline \multicolumn{6}{|c|}{ Total solids ( $\mathrm{g} / \mathrm{kg}$ brine) } \\
\hline by evaporation & 169 & 171 & 197 & 196 & 208 \\
\hline
\end{tabular}


salinity system with 14,600 to $72,000 \mathrm{ppm}$ TDS at 950-1800 m depth (Table 4-3). A fence diagram illustrating some of these horizontal variations in salinity is shown in Figure 4-11 (Muramoto, 1982). Vertical gradients in salinity are somewhat more difficult to quantify, since geothermal wells are normally completed with an open interval which may be a hundred meters or more thick. Thus brine can flow into the well over a large interval, even though brines in other parts of the section are excluded by the well casing. A crude estimate of vertical changes in salinity may be made by examining adjacent wells which are completed at different depths. Better still are drill stem tests made during drilling, but these are rarely done and the data are often held proprietary. For the well sinclair No. 4, Helgeson (1968) estimated the change of salinity with depth by calculating a unit isochore for a simulated brine, as temperature and salinity both rise together (Figure 4-12). This concept was verified in this well by determining the depression of freezing points of fluid inclusions from various minerals at different depths (Freckman, 1978). These last data indicate approximately 5-10 percent salinity at 220-240 C, whereas the re is 15-25 percent salinity of 270-300 C.

\subsubsection{Source of the Brine}

When these metal- and chloride-rich brines were first discovered it was suggested that the origin of the metals was magmatic and that the SSGF provided an unusual opportunity to analyze magmatic fluids (White et al, 1963). Later isotopic studies of the brines and the associated hydrothermally altered sediments revealed that most of the water must be meteoric (Craig, 1966, 1969; Clayton et a1, 1968; White, 1968). Craig (1966) found that the brines in the SSGF had a 60 of -75 per mil, similar to the local meteoric water. Values of $\delta^{18} 0$ for SSGF brines varied between -11 and +3 per $m 11$ and were systematically related to chlorinity. The rocks, on the other hand, are greatly depleted from an original $\delta^{18} 0$ of 18 to 8 per mil due to exchange of oxygen during water/rock reactions. This oxygen isotopic data requires reaction with a meteoric water with initially lower values of $\delta^{18} 0$ than is possible in magmatic waters (Craig, 1966).

Although meteoric water is now generally recognized as the dominant water source within the reservoir, views on the nature of the recharge differ. 
Table 4-3. Chemical and Isotopic Data for Fluids Produced from the Westmorland Geothermal System

\begin{tabular}{|c|c|c|c|c|c|c|}
\hline & & & & Kalin & Dearborn & Dearborn \\
\hline & Landers No. 1 & Landers No. 2 & Landers No. 3 & Farms No. 1 & Farms No. 1 & Farms No. 2 \\
\hline Sample interval, m & $1818-2349$ & $1818-2288$ & $949-1414$ & $1632-2588$ & $1631-2438$ & $946-1373$ \\
\hline pH & 5.3 & 5.5 & 8.0 & 7.8 & 8.3 & 7.3 \\
\hline TDS, $\mathrm{mg} / \mathrm{l}$ & 72,083 & 57,657 & 26,640 & 48,894 & 14,652 & 21,910 \\
\hline $\mathrm{SiO}_{2}, \mathrm{mg} / \mathrm{l}$ & 270 & 237 & 95 & 298 & 319 & 118 \\
\hline $\mathrm{Ca}, \mathrm{mg} / \mathrm{l}$ & 2,333 & 1,887 & 9.7 & 758 & 13.2 & 88 \\
\hline $\mathrm{Mg}, \mathrm{mg} / \mathrm{l}$ & 60 & 52 & 12.5 & 64.7 & 3.34 & 26.5 \\
\hline $\mathrm{Na}, \mathrm{mg} / \mathrm{l}$ & 20,333 & 19,420 & 9,000 & 12,474 & 4,356 & 7,000 \\
\hline$K, \mathrm{mg} / \mathrm{l}$ & 2,033 & 1,231 & 470 & 3,234 & 295 & 930 \\
\hline $\mathrm{HCO}_{3}, \mathrm{mg} / \mathrm{l}$ & 84 & 45 & 5,001 & 239 & 994 & 6,590 \\
\hline $\mathrm{CO}_{3}, \mathrm{mg} / \mathrm{l}$ & 0 & 0 & 0 & 0 & 136 & 0 \\
\hline $\mathrm{SO}_{4}, \mathrm{mg} / \mathrm{l}$ & $<1$ & 19 & 16.3 & 41 & 42 & 70 \\
\hline $\mathrm{Cl}, \mathrm{mg} / \mathrm{l}$ & 35,600 & 33,880 & 10,710 & 23,507 & 6,072 & 7,960 \\
\hline $\mathrm{Br}, \mathrm{mg} / \mathrm{l}$ & 14.5 & 9.7 & 5.6 & 19.4 & 10 & 10 \\
\hline$F, m g / l$ & 2.3 & 2.3 & 1.14 & 1.62 & 0.82 & 0.98 \\
\hline$B, \mathrm{mg} / \mathrm{l}$ & 143 & 115 & 108 & 77.6 & 46.6 & 70 \\
\hline$\delta^{18} 0(S M O W)$, per mil & +2.2 & +3.4 & -1.5 & -3.6 & NA & -3.7 \\
\hline$\delta D($ SMOW), per mil & -82.9 & -85.4 & -86.2 & -81.5 & NA & -88.6 \\
\hline Trituim units & 2.9 & NA & 0.6 & NA & $N A$ & 7.0 \\
\hline
\end{tabular}

Source - 0lson and Matlick, 1978. 


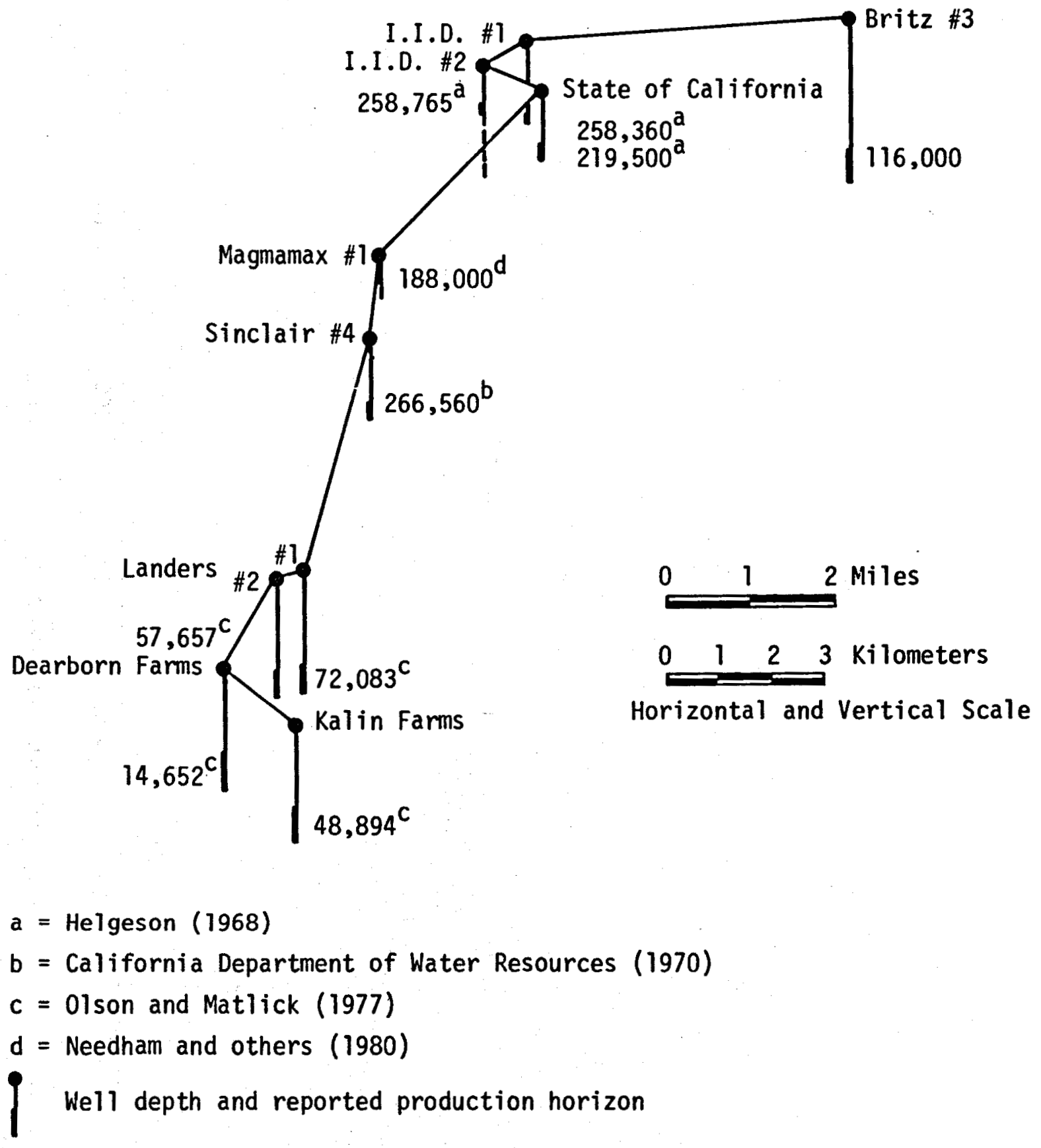

Figure 4-11. Fence Diagram Showing Well Depth, Perforated Interval, and Formation Fluid Salinity for Selected Wells in the Salton Sea and Westmorland Geothermal Areas.

Salinity data are in ppm total dissolved solids (Source Muramoto, 1982, Fig. 42). 


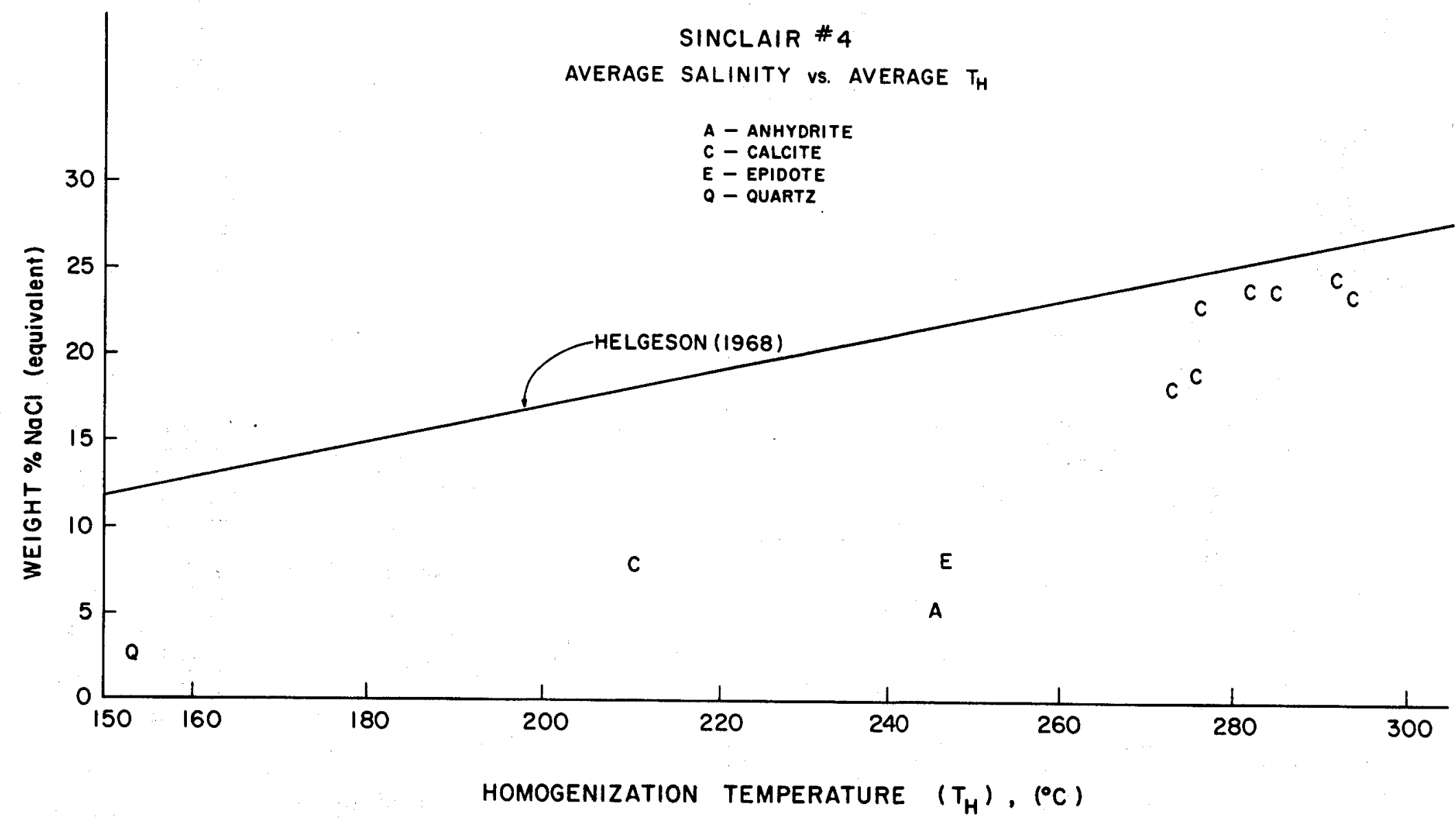

Figure 4-12. Average Salinity Versus Homogenization Temperature of Fluid Inclusions in Well Sinclair 4.

These values are compared with Helgeson's (1968) calculated unit isochore for a simulated geothermal brine in the system $\mathrm{KCl}-\mathrm{CaCl}_{2}-\mathrm{NaCl}-\mathrm{H}_{2} \mathrm{O}$

$\left(\mathrm{KCl}: \mathrm{CaCl}_{2}: \mathrm{NaCl}=1: 1.95: 3.55\right.$ by weight) (Source - Freckman, 1978). 
Craig (1966) suggested recharge was from the local precipitation in the Chocolate Mountains to the east. White (1968) accepted this hypothesis and proposed that the high salinity of the brine was partly due to dissolution of subsurface freshwater evaporites. Berry (1966) proposed that membrane filtration of meteoric water could account for the high salinity, and Helgeson (1968) appealed to boiling and evaporative concentration of Colorado River water in a closed geothermal system prior to deposition of the mudstone caprock. Craig (1969) pointed out, however, that evaporative concentration would produce waters isotopically heavier than the waters observed. More recently Coplen (1976) showed that meteoric water in the Imperial Valley is heavier ( $S D=-63$ per mil) than Craig had determined. From this evidence and from hydrologic studies indicating groundwater flow from the southeast towards the Salton Sea (Loeltz et al, 1975), Coplen (1976) demonstrated that all the subsurface waters in the central Imperial Valley are partly evaporated Colorado River water. The salinity gradients referred to above and isotopic data of 01 son and Matlick (1978) support the model of inflow of fresher water from the south towards the SSGF. This interpretation is also supported by $\mathrm{Cl} / \mathrm{Br}$ ratios that are similar to each other and to Colorado River water, but are about three times higher than is observed in seawater (White, 1981) (see a] so section 3.7 ).

\subsubsection{Source of the Metals}

If the source of the water is evolved and evaporated Colorado River water, and the source of the halogens is freshwater evaporite, what then is the source of the metals? Doe et al (1966) made a radiogenic tracer study of $\mathrm{Pb}$ and $\mathrm{Sr}$ to determine the source of these and presumably other heavy metals in Salton Sea brines. Isotopic evidence indicates that 80-100 percent of $\mathrm{Sr}$ and 50-100 percent of $\mathrm{Pb}$ has been leached from the associated Colorado River delta sediments by reaction with brines at high temperature. These $\mathrm{Sr}$ and $\mathrm{Pb}$ data do not preclude the possibility of some metals being derived from a magmatic source. $\mathrm{Li}, \mathrm{B}, \mathrm{NH}_{3}, \mathrm{Sr}$ and $\mathrm{Pb}$ have most probably been leached from the sediments (White, 1981). Similarly the average values of $\delta^{34} S$ in eight sulfide samples from the SSGF is 1.1 per mil (White, 1968), near the meteorite standard. According to White (1981) this $S$ isotopic ratio is commonly taken 
to indicate that the source of the sulfur is magmatic, which is reasonable in terms of the tectonic setting and the youth of the rhyolite domes in the SSGF $(16,000$ years; Muffler and White, 1969). On the other hand, the sulfur could be derived from the sediments which in turn derive from the erosion of igneous rocks.

\subsubsection{Pipe Scales from the Early Wells}

One effect of the great concentration of metals with chalcophile affinity in these brines is that they precipitate sulfur-rich scales when flashed to the atmosphere. Quantitative analyses of these sulfide-rich scales have been published by Skinner et al (1967) (Table 4-4).

Bulk compositional data for three scale samples are given in Tables 4-5 and 4-6. The occurrence of native $\mathrm{Ag}$ in assemblages lacking digenite agrees with phase relations in the system $\mathrm{Cu}-\mathrm{Ag}-\mathrm{S}$. The Fe rich opaline scale contains an average of 20 wt percent $\mathrm{Cu}$ and up to $6 \mathrm{wt}$ percent $\mathrm{Ag}$ in sulfide phases and as native $\mathrm{Ag}$ (Skinner et al, 1967). Although $\mathrm{Pb}$ and $\mathrm{Zn}$ are abundant in the brine (Table 4-3), these metals did not compete successfully with $\mathrm{Cu}$ and $\mathrm{Ag}$ for the limited available sulfur (<30 ppm) in the brine.

The pipe scale represents a non-equilibrium assemblage of mineralization. Flow in a steam well is virtually adiabatic, and pressure at a certain production depth in the well is constant under steady-state conditions. Therefore, expansion of the fluid in a flowing well is isenthalpic as well as adiabatic (Helgeson, 1968). Brine is produced at high velocities through an iron pipe with no chance to react with wall rocks or with cooler surface waters of different compositions (Skinner et al, 1967). On flashing to the atmosphere, cooling is extremely rapid and steam and gas phases separate from the brine upon pressure release. Thus conditions of scale deposition are far from equilibrium, with kinetic factors probably controlling mineral assemblages (Skinner et al, 1967). The sulfide-opal assemblage is deposited in the well head and discharge pipes with surprising rapidity under these conditions. In a three month test period of discharging the I.I.D. No. 1 well, even though 5 to 8 tons of scale were deposited, $<0.1$ percent of the total heavy metals (including Fe) were removed from solution as pipe scaling. However, the scales contained about 20 percent copper and precious metal, with values of several kilograms of silver and several grams of gold per tonne. 
Table 4-4. Sulfide Minerals in Pipe Scales from the SSGF

\begin{tabular}{lcc}
\hline \multicolumn{1}{c}{ Name } & Formula & $\begin{array}{c}\text { Atomic Ratios: } \\
\text { Metals/S }\end{array}$ \\
\hline Digenite & $\mathrm{Cu}_{9} \mathrm{~S}_{5}$ or $(\mathrm{Cu}, \mathrm{Ag})_{9} \mathrm{~S}_{5}$ & $9 / 5$ \\
Bornite & $\mathrm{Cu}_{5} \mathrm{FeS}_{4}$ or $(\mathrm{Cu}, \mathrm{Ag})_{5} \mathrm{FeS}_{4}$ & $6 / 4$ \\
Chalcocite and & $\mathrm{Cu}_{2} \mathrm{~S}$ or $(\mathrm{Cu}, \mathrm{Ag})_{2} \mathrm{~S}$ & $2 / 1$ \\
$\quad$ "dense" chalcocite & & \\
Stromeyerite & $\mathrm{CuAgS}$ & $2 / 1$ \\
Arsenopyrite & $\mathrm{FeAsS}$ & $2 / 1$ \\
Tetrahedrite & $(\mathrm{Cu}, \mathrm{Ag}, \mathrm{Zn}, \mathrm{Fe})_{12}(\mathrm{Sb}, \mathrm{As})_{4} \mathrm{~S}_{13}$ & $16 / 13$ \\
Chalcopyrite & $\mathrm{CuFeS}_{2}$ & $2 / 2$ \\
Pyrite & $\mathrm{FeS}_{2}$ & $1 / 2$ \\
\hline
\end{tabular}

Source - Skinner et al (1967). 
Table 4-5. XRF Analyses of Sulfide-Rich Layers of Well Scales in I.I.D. No. 1

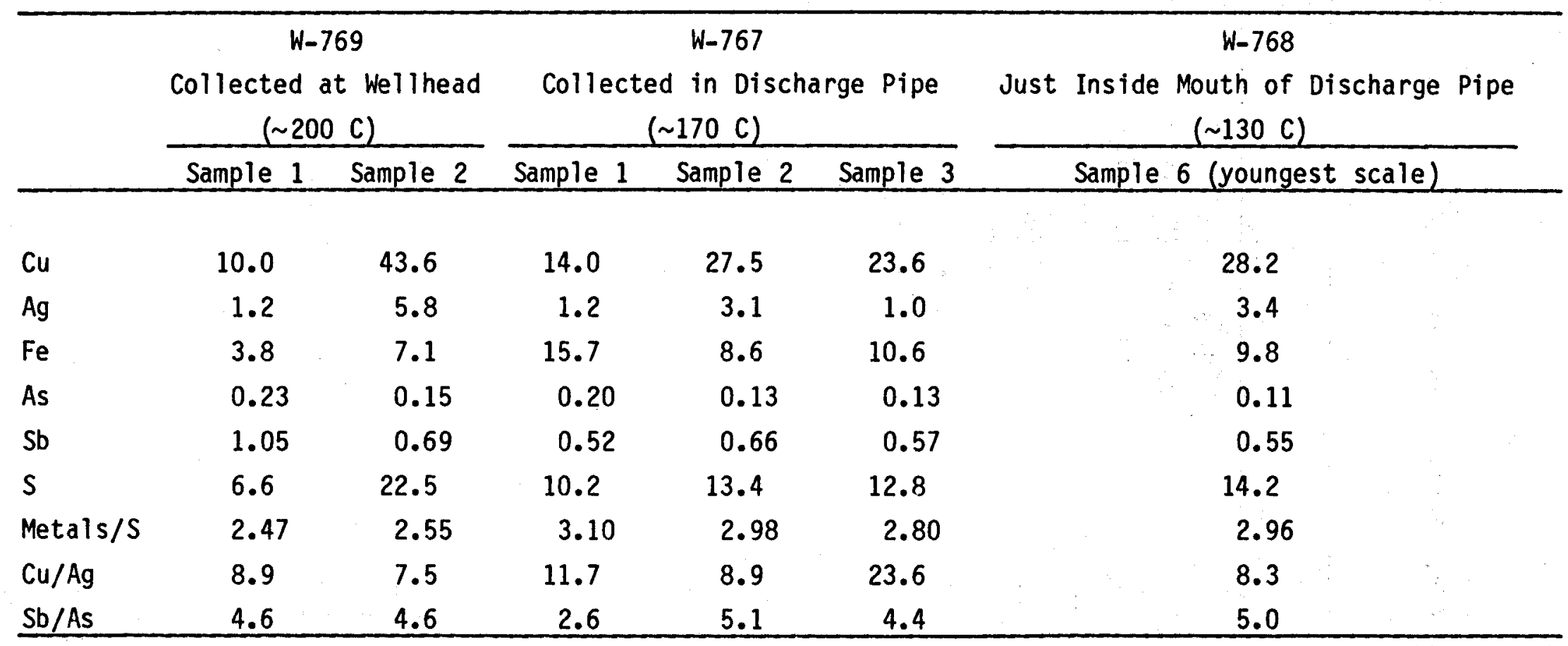

All concentrations in wt percent (Source - Skinner et al, 1967, Table 4). 
Table 4-6. Quantitative Spectrographic Analyses of Sulfide-Rich Scale in I.I.D. No. 1

\begin{tabular}{lccc}
\hline & $W-769$ & $W-767$ & $W-768$ \\
\hline $\mathrm{Zn}$ & - & -- &.- \\
$\mathrm{Pb}$ & .012 & .011 & .007 \\
$\mathrm{Cu}$ & $1^{*}$ & $1^{\star}$ & $1^{\star}$ \\
$\mathrm{Ag}$ & $7.0^{\star}$ & 1.3 & 2.8 \\
$\mathrm{Fe}$ & 5.0 & 7.0 & 6.0 \\
$\mathrm{Mn}$ & .055 & 0.42 & 0.34 \\
$\mathrm{Na}$ & $1^{\star}$ & $1^{*}$ & $1^{*}$ \\
$\mathrm{Ca}$ & 0.55 & 0.60 & 0.55 \\
$\mathrm{~K}$ & $1.5^{*}$ & $1.0 *$ & $1.5^{\star}$ \\
$\mathrm{B}$ & .019 & 0.11 & .080 \\
$\mathrm{Ba}$ & .014 & .020 & .0090 \\
$\mathrm{Co}$ & .0050 & $<.0004$ & .0006 \\
$\mathrm{Sb}$ & 0.72 & 0.17 & 0.25 \\
$\mathrm{Cd}$ & &.-- &.- \\
\hline
\end{tabular}

* Above or below best range for quantitative analysis $\ldots$ method used.

Values given in wt percent (Source - Skinner et al, 1967, Table 2). 
More elaborate tests of the chemistry of scale formation performed by Harrar et al (1979) and Austin et al (1977) showed that the conditions of flashing have a major effect on the chemistry of these scales. Table 4-7 (Maimoni, 1982) shows typical metal contents for two wells in the field, whereas scale compositions under various conditions are shown in Table 4-8 (Harrar et al, 1979).

Different compounds precipitate at different parts of multistage flash equipment, depending on the concentration of $\mathrm{H}_{2} \mathrm{~S}$ and $\mathrm{CO}_{2}$ and the time elapsed since flashing of the brine. Copper is concentrated in the highest temperature stage. Here, because cooling occurred in the presence of evolved $\mathrm{H}_{2} \mathrm{~S}$ caused by flashing through an exhaust nozzle, the well head scale contained 88 wt percent $\mathrm{PbS}$ and 0.34 wt percent $\mathrm{Ag}$. The fluids contained high contents of $\mathrm{Mn}$ and Pt and are of interest as potential "ores" for these important strategic metals.

\subsection{SUBSURFACE GEOLOGY OF THE SSGF}

The SSGF lies beneath irrigated fields, the ponds and marshes of a bird sanctuary, and the waters of the Salton Sea. The only rocks which crop out are the five small rhyolite domes referred to above (Figure 4-7), and the Recent deposits of the former Lake Cahuilla, ancestral to, but larger than, the present Salton Sea.

In spite of the large number of existing deep boreholes, the subsurface sedimentological and paleontological characteristics of the SSGF has never been fully synthesized. Studies of cuttings and cores have hitherto emphasized water/rock reactions rather than sedimentology. Some parastratigraphic and structural studies have been done, however, using wireline logs.

\subsubsection{Parastratigraphy}

The first and most comprehensive parastratigraphic study, done by Randall (1974)', was based upon downhole wireline logs, including temperature logs, from 16 wells chiefly in the west-central portion of the field. This study was augmented by that of Tewhey (1977) who, in addition, studied cuttings and 
Table 4-7. "Typical" Analysis for Magmamax No. 1 and Sinclair No. 4 Brines

Magmamax No. 1

Sinclair No. 4

Total solids $(\mathrm{g} / \mathrm{l})$

$\mathrm{pH}$

Eh (vs. NHE)

Composition (ppm)

$\mathrm{SiO}_{2}$

$\mathrm{NH}_{3}$

Li

K

$\mathrm{Rb}$

$\mathrm{Mg}$

$\mathrm{Sr}$

$\mathrm{Ba}$

$\mathrm{Mn}$

$\mathrm{Fe}$

Co

Mo

$\mathrm{Cu}$

Zn

B

Sn

$\mathrm{Pb}$

As

$\mathrm{Sb}$

Bi

Se

$\mathrm{Ag}$

$\mathrm{Au}$

$\mathrm{Pt}$

190

5.6

0.18

200

45

117

8500

56

75

366

290

565

422

0.3
4
0.8

226

10

23

70

0.2

4

5

6

0.5

0.1

0.06
294

5.2

0.18

506

440

245

14300

25

68

600

1260

1300

--

3

500

300

--

90

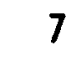

7

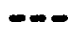

2.5

0.5

0.1

0.06

Source - Maimoni, 1982. 
Table 4-8. Analyses of Scale from Magmamax No. 1 Well head and the LLNL Four-stage Flash System After $\sim 720 \mathrm{H}$ of Operation

\begin{tabular}{|c|c|c|c|c|c|c|c|c|}
\hline \multirow[b]{2}{*}{ Element } & \multirow[b]{2}{*}{$\begin{array}{l}\text { Wellhead, } \\
220^{\circ} \mathrm{C}\end{array}$} & \multirow[b]{2}{*}{$\begin{array}{c}\text { Separated } \\
\text { unmodified } \\
\text { brine, } \\
200-220^{\circ} \mathrm{C}\end{array}$} & \multicolumn{3}{|c|}{ Composition, wt $\%$} & \multirow[b]{2}{*}{$\begin{array}{l}\text { 3rd-stage } \\
\text { steam, } \\
125^{\circ} \mathrm{C}\end{array}$} & \multirow[b]{2}{*}{$\begin{array}{c}\text { 4th-stage } \\
\text { brine, } \\
110^{\circ} \mathrm{C}\end{array}$} & \multirow[b]{2}{*}{$\begin{array}{l}\text { Delay } \\
\text { line, } \\
85^{\circ} \mathrm{C}\end{array}$} \\
\hline & & & $\begin{array}{c}\text { 2nd-stage } \\
\text { brine, } \\
150^{\circ} \mathrm{C}\end{array}$ & $\begin{array}{c}\text { 2nd-stage } \\
\text { steam, } \\
150^{\circ} \mathrm{C}\end{array}$ & $\begin{array}{c}\text { 3rd-stage } \\
\text { brine, } \\
125^{\circ} \mathrm{C}\end{array}$ & & & \\
\hline Si as $\mathrm{SiO}_{2}$ & 2 & 27 & 60 & 27 & 64 & 64 & 49 & 39 \\
\hline & n.d. & 0.1 & 0.03 & 0.1 & 0.03 & 0.01 & 0.01 & 0.1 \\
\hline $\mathrm{Na}$ & n.d. & 10 & 3 & 1 & 3 & 3 & 1 & 20 \\
\hline K & $<0.5$ & 1.6 & 1.3 & 1.5 & 0.64 & 0.82 & 0.8 & 1.4 \\
\hline $\mathbf{R} \mathbf{b}$ & $<0.1$ & 0.01 & 0.02 & 0.02 & 0.007 & 0.004 & 0.003 & 0.01 \\
\hline Be & n.d. & 0.0003 & 0.001 & 0.0006 & 0.0003 & 0.0003 & 0.002 & 0.0001 \\
\hline $\mathbf{M g}_{\mathbf{g}}$ & n.d. & 0.2 & 0.02 & 0.02 & 0.02 & 0.05 & 0.03 & 0.02 \\
\hline $\mathrm{Ca}$ & 2 & 4.2 & 2.0 & 1.2 & 2.7 & 2.9 & 26 & 6.1 \\
\hline Sr & trace & 0.06 & 0.04 & 0.01 & 0.22 & 0.03 & 0.12 & 0.40 \\
\hline $\mathrm{Ba}$ & $<0.1$ & $<0.1$ & $<0.1$ & $<0.1$. & 3.5 & 0.32 & 1.2 & 5.3 \\
\hline B & n.d. & 0.03 & 0.03 & 0.2 & 0.03 & 0.05 & 0.1 & 0.05 \\
\hline Al & n.d. & 0.1 & 0.3 & 2 & 0.1 & 0.2 & 0.2 & 0.02 \\
\hline $\mathbf{Y}$ & $<1$ & $<0.005$ & 0.01 & 0.1 & $<0.005$ & $<0.005$ & 0.02 & $<0.005$ \\
\hline $\mathbf{S}$ & 12 & 2.4 & $<1.0$ & $<1.0$ & $<1.0$ & $<1.0$ & 1.5 & 2.3 \\
\hline As & n.d. & 0.15 & 0.32 & 0.97 & 0.21 & 0.45 & 0.07 & 0.11 \\
\hline Sb & trace & 0.019 & 0.22 & 0.65 & 0.11 & 0.27 & 0.069 & 0.083 \\
\hline $\mathrm{Ti}$ & 0.03 & $<0.05$ & $<0.05$ & $<0.05$ & $<0.5$ & $<0.05$ & $<0.2$ & $<0.8$ \\
\hline $\mathrm{Cr}$ & 0.09 & $<0.02$ & 0.03 & 0.34 & $<0.2$ & $<0.01$ & $<0.05$ & $<0.3$ \\
\hline$M n$ & 0.03 & 0.67 & 0.21 & 0.27 & 0.12 & 0.12 & 0.03 & 0.12 \\
\hline Fe & 0.7 & 22 & 7.1 & 14 & 2.4 & 6.0 & 1.4 & 0.59 \\
\hline $\mathrm{Ni}$ & 0.01 & $<0.01$ & 0.19 & 1.7 & 0.07 & 0.16 & 0.05 & $<0.01$ \\
\hline Mo & n.d. & $<0.002$ & $<0.002$ & 0.004 & $<0.002$ & $<0.002$ & $<0.002$ & $<0.002$ \\
\hline $\mathbf{A g}_{\mathbf{g}}$ & 0.34 & 0.008 & 0.028 & 0.11 & 0.024 & 0.056 & 0.01 & 0.012 \\
\hline $\mathrm{Cu}$ & 0.02 & 1.0 & 0.4 & 0.5 & 0.2 & 0.6 & 0.15 & 0.08 \\
\hline $\mathrm{Zn}$ & 0.07 & 0.11 & 0.04 & 0.03 & 0.06 & 0.09 & 0.02 & 0.08 \\
\hline $\mathbf{P b}$ & 76 & 1.3 & 0.16 & 0.08 & 0.55 & 0.90 & 0.21 & 0.25 \\
\hline $\mathrm{Cl}$ & n.d. & 7.9 & 9.9 & 1.7 & 7.7 & 4.3 & 3.2 & 18 \\
\hline $\mathrm{Br}$ & n.d. & 0.02 & $<0.01$ & $<0.01$ & $<0.01$ & $<0.01$ & $<0.01$ & $<0.01$ \\
\hline $\mathbf{F}$ & n.d. & n.d. & n.d. & n.d. & n.d. & n.d. & 26 & n.d. \\
\hline
\end{tabular}

n.d. = not determined

(Source - Harrar et al, 1979). 
cores from the Magmamax No. 2, Magmamax No. 3 and Woolsey No. 1 wells. These data revealed a lithologic sequence of shales and sandstones consisting of (1) a caprock; (2) an upper reservoir of slightly altered rocks; and (3) a lower reservoir of highly altered rocks (Figure 4-13). According to Randall (1974) the caprock is a sedimentary unit primarily composed of lacustrine clays and silts. In the vicinity of the Magmamax wells, the caprock is 340 to $370 \mathrm{~m}$ thick and is composed of two distinct layers. The upper $200 \mathrm{~m}$ consists of unconsolidated clay and silt which, because of its uncemented nature, is poorly represented in drill cuttings. The lower layer consists of consolidated clays, silts, and sands, with a carbonate cement, intercalated with consolidated silts with anhydrite cement presumed to be evaporite layers. These rocks apparently record sequences of inundation and desiccation of freshwater lakes which preceded the modern Salton Sea.

Using combined spontaneous-potential and resistivity logs, Randall (1974) mapped the thickness of the sedimentary caprock (Figure 4-14). Over a distance of six kilometers the caprock varies from zero thickness in the south to $430 \mathrm{~m}$ thick in Elmore No. 1. Randall's map (Figure 4-14) shows the caprock as a wedge thickening to the northwest and bounded to the west by a fault detected by the dipmeter log of Magmamax No. 2. The base of this wedge shows considerable relief in the east-west direction. Lack of depth correlation between adjacent wells led Randall to infer several growth faults which offset the caprock (Figure 4-14).

The caprock lies in apparently unconformable relationship on the underlying upper reservoir sequence. Younker et al (1982, p. 225) assert that the sharp transition between reservoir rocks and the overlying caprock represents the boundary between lacustrine sediments above and underlying "marine sediments", which were deposited before the Salton Trough was isolated from the southern portion of the basin in the "mid-pleistocene" times. However, they do not present evidence for these rocks being "marine" in character.

Although Woodward (1974) reports intermittent shallow marine rocks of mid-Pleistocene age in the western part of the Imperial valley, there are no published paleontological data from any of the wells in the central portions of the Imperial valley, including the SSGF (see section 3.2). Similarly, as was stated above, $\mathrm{Cl} / \mathrm{Br}$ ratios support the idea that the origin of the salt is 


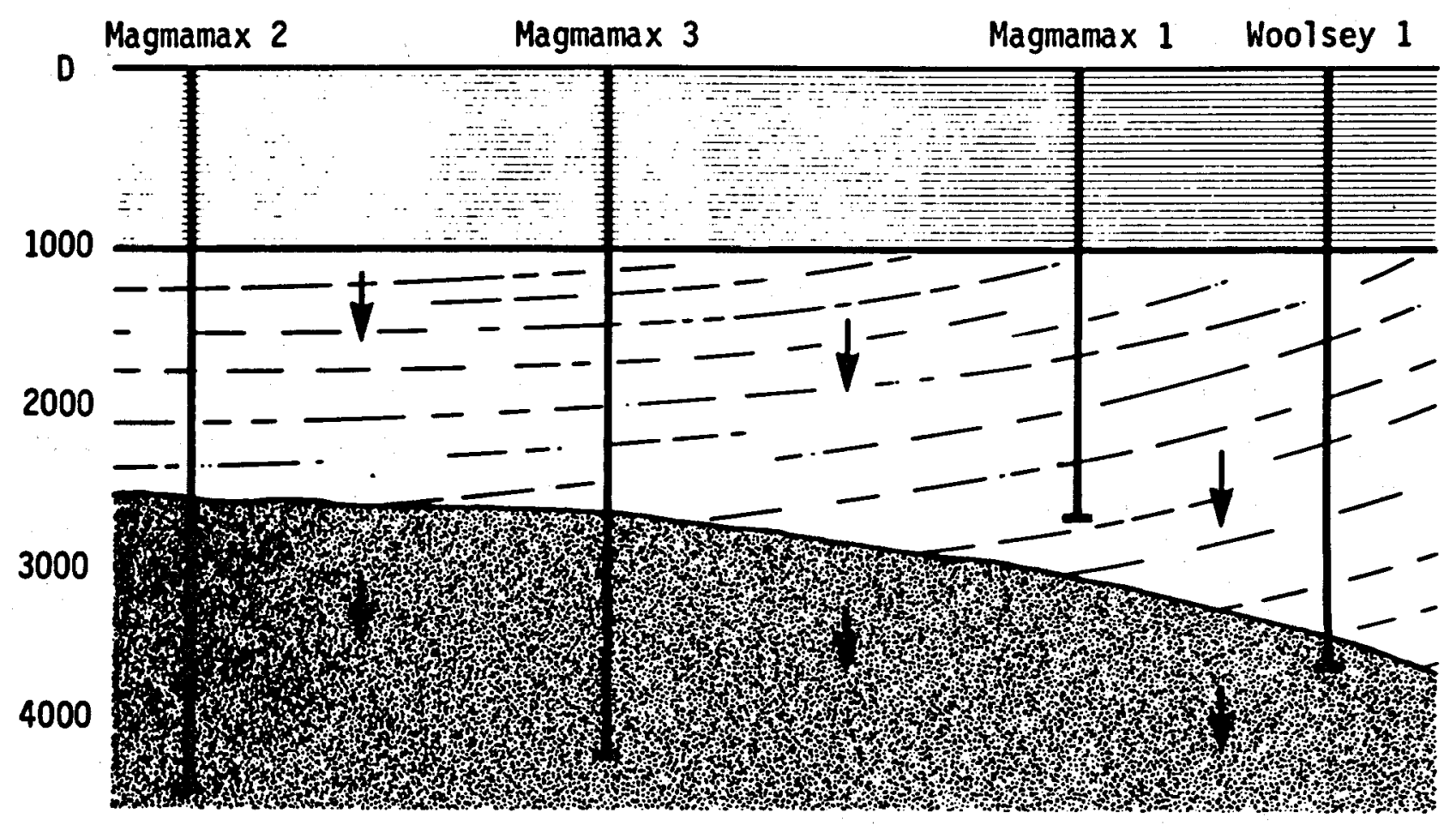

Caprock

Unal tered reservoir rock

Hydrothermally altered reservoir rock

E-- Indication of dip of sedimentary strata

$\downarrow$ Direction of decreasing porosity/permeability

Figure 4-13. East-west Cross Section Through the Magmamax and Wool sey Wells in the Salton Sea Geothermal Field.

The three rock types, i.e., cap rock, slightly altered reservoir rock, and hydrothermally altered reservoir rock, are classifications based on petrographic analysis. The orientation of strata in the reservoir rock is shown by dashed lines. For well locations see Figure 4-1 (Source - Tewhey, 1977, Fig. 23). 


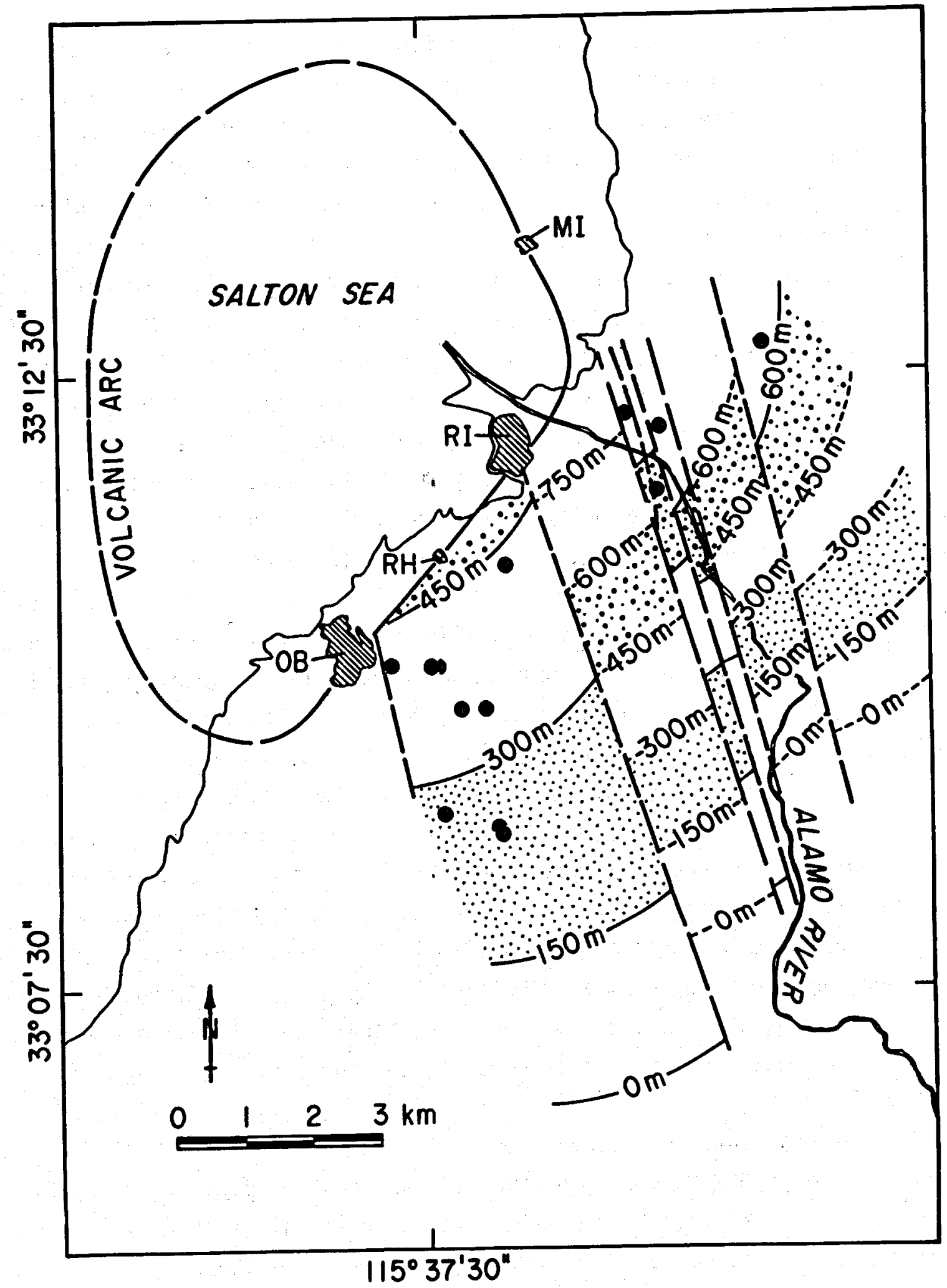

Figure 4-14. Depth of the Base of the Sedimentary Caprock. The "volcanic arc" of Randall connects a series of small amplitude magnetic anomalies through the five rhyolite domes (see Figure 4-3). (Modified from Randall, 1974, Fig. 5). 
freshwater evaporite (section 3.7.2) and isotopic studies indicate that the water is evolved and partially evaporated Colorado River water (section 3.7.1). Finally, the presence of a true marine sedimentary facies is not supported by studies of the wireline logs and cuttings here or elsewhere in the central Imperial valley. Rapid facies changes, involving lenticular sand bodies and intercalated laminated silts and mud rocks with steep depositional dips, are characteristic of deposition in a prograding delta. Correlation, even at outcrop, is difficult even over a few hundred meters (Wagoner, 1977). The lenticular nature of the sedimentary units and their steeply dipping progradational nature in the SSGF is also most apparent in unpublished, proprietary, seismic reflection (Vibroseis) profiles.

Apart from lacustrine facies, the sedimentary facies present in the central Imperial Valley are deltaic sands and silts, dune-braided stream deposits, and channel-fill pebble-bearing sands (Bird and Elders, 1976), none of which have a true marine aspect. The upper reservoir in the SSGF consists of terrigenous deltaic sands, silts, and muds, with occasional lacustrine and stream deposits. The sands are indurated quartz feldspar arenites and lithic wackes containing minor detrital mica and chlorite, with varying degrees of calcite cement and intergranular porosity of 10 to 30 percent. The amount of calcite cementation is greatest near the top of the section, beneath the clay caprock. With increasing depth and temperature, dissolution of carbonates can lead to appreciable secondary porosity. The argillaceous rocks are indurated mudstones and fine-grained siltstones consisting of clay-sized quartz, feldspar, and calcite together with kaolinite, montmorillonite and detrital illite as the chief clay minerals (Muffler and Doe, 1968). Although sporadic thin lignite beds are present, caution is necessary in estimating their thickness, as most lignite seen in borehole cuttings is a drilling mud additive.

In the west-central portion of the SSGF the thickness of the upper reservoir zone is 500 to $600 \mathrm{~m}$; however, in the eastern part of the field near $\mathrm{Nil}$ and, the upper reservoir zone is much thicker and the sedimentary section is much more argillaceous. With increasing temperature, there is a fairly rapid transition into the lower reservoir which consists of indurated hydrothermally altered reservoir rocks. Younker et al (1982) define the top of the upper reservoir as being the first appearance of authigenic epidote at 
280 C. However other workers have observed epidote apperance at $225 \mathrm{C}$ (McDowell and Elders, 1979, 1980). Randall (1974) defined the top of the lower reservoir as being the top of a metamorphic zone where shales and carbonates react to form chlorite by decarbonation reactions. The physical changes accompanying these reactions cause marked loss of porosity in the shales and cause them to acquire electrical log characteristics similar to carbonate rocks (low spontaneous potential and high resistivity). Invariably, sandstones and siltstones are affected more by recrystallization than are less permeable shales. The changes induced by reactions of the rocks with hot brines (described in section 4.5 ) eventually lead to destruction of porosity and reduction in permeability (Figure 4-15) with increasing temperature.

\subsubsection{Subsurface Structure}

In the west-central portion of the field, in the area studied by Randall (1974) and Tewhey (1977), the strata dip west at $10^{\circ}$. Although correlation is difficult, Randall (1974) attempted correlations between 16 wells by defining parastratigraphic units using percentage volume of sand bodies per $160 \mathrm{~m}$ (500 $\mathrm{ft}$ ) intervals (Figure 4-16). Randall also was able to correlate certain distinctive marker beds between some adjacent wells. An example of this approach is seen in Figure 4-17 which shows correlation on a north-south profile through five wells using spontaneous potential logs to correlate sand-shale boundaries and thicknesses of distinctive units. Such cross sections define a broad syncline with an east-west axis plunging gently west. A general tendency for thickening of individual sedimentary units from north to south is also shown (Figure 4-17).

\subsubsection{Influence of Structure on Heat Transfer}

One of the important outcomes of these parastratigraphic and structural studies was the finding that the isotherms are not controlled to any apparent extent by local sedimentary stratigraphic and structural relationships (Randa11, 1974). Isothermal surfaces are seen to transect sedimentary bedding, ignoring the strike and dip of the strata. Similarly the temperature cross sections seem unaffected by the locations of postulated faults. Randall 


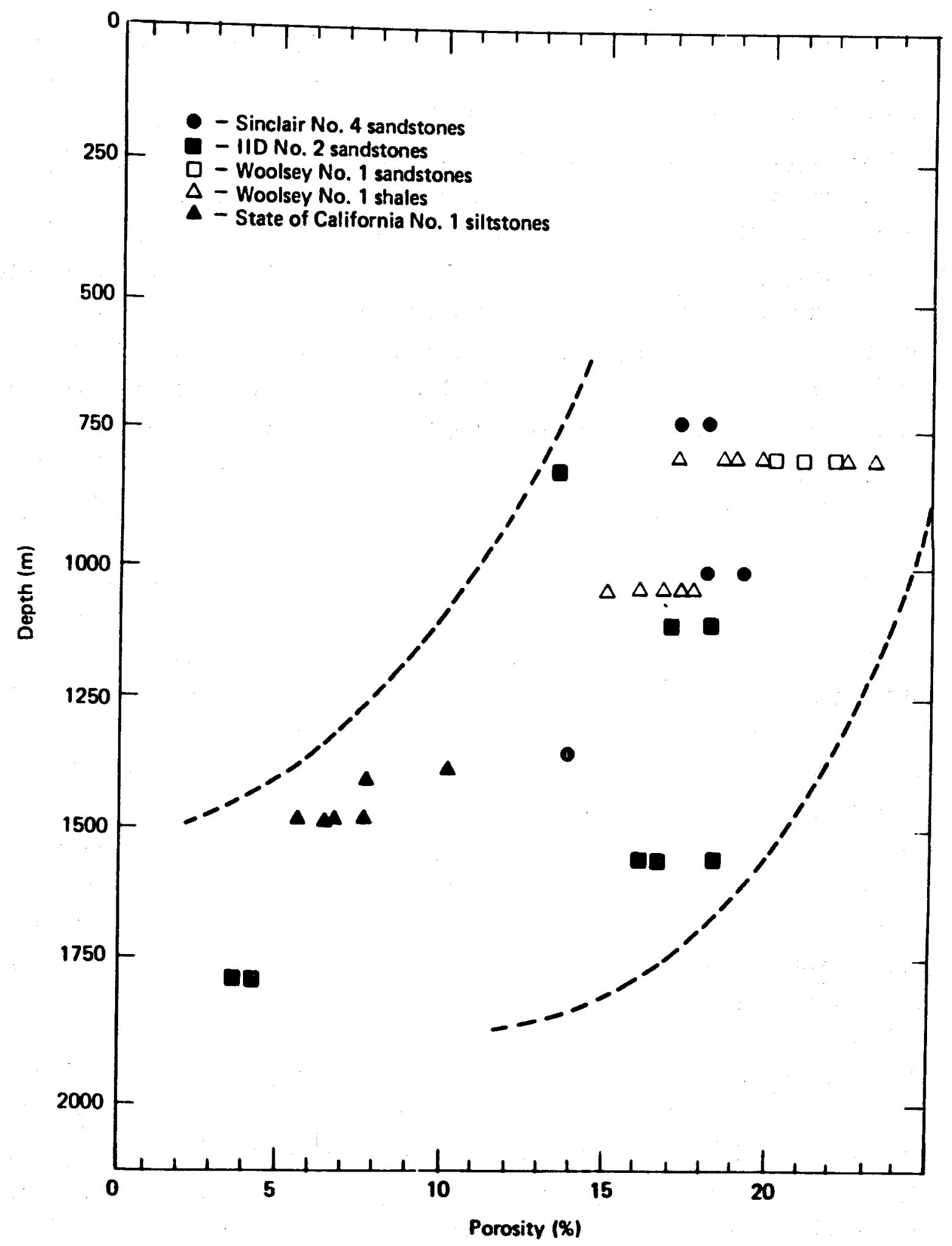

Figure 4-15. Measured Porosity Versus Depth for Cores from Five Geothermal Wells in the Salton Sea Geothermal Field.

(Source - Younker et al, 1982, Fig. 4). 
PARASTRATIGRAPHY

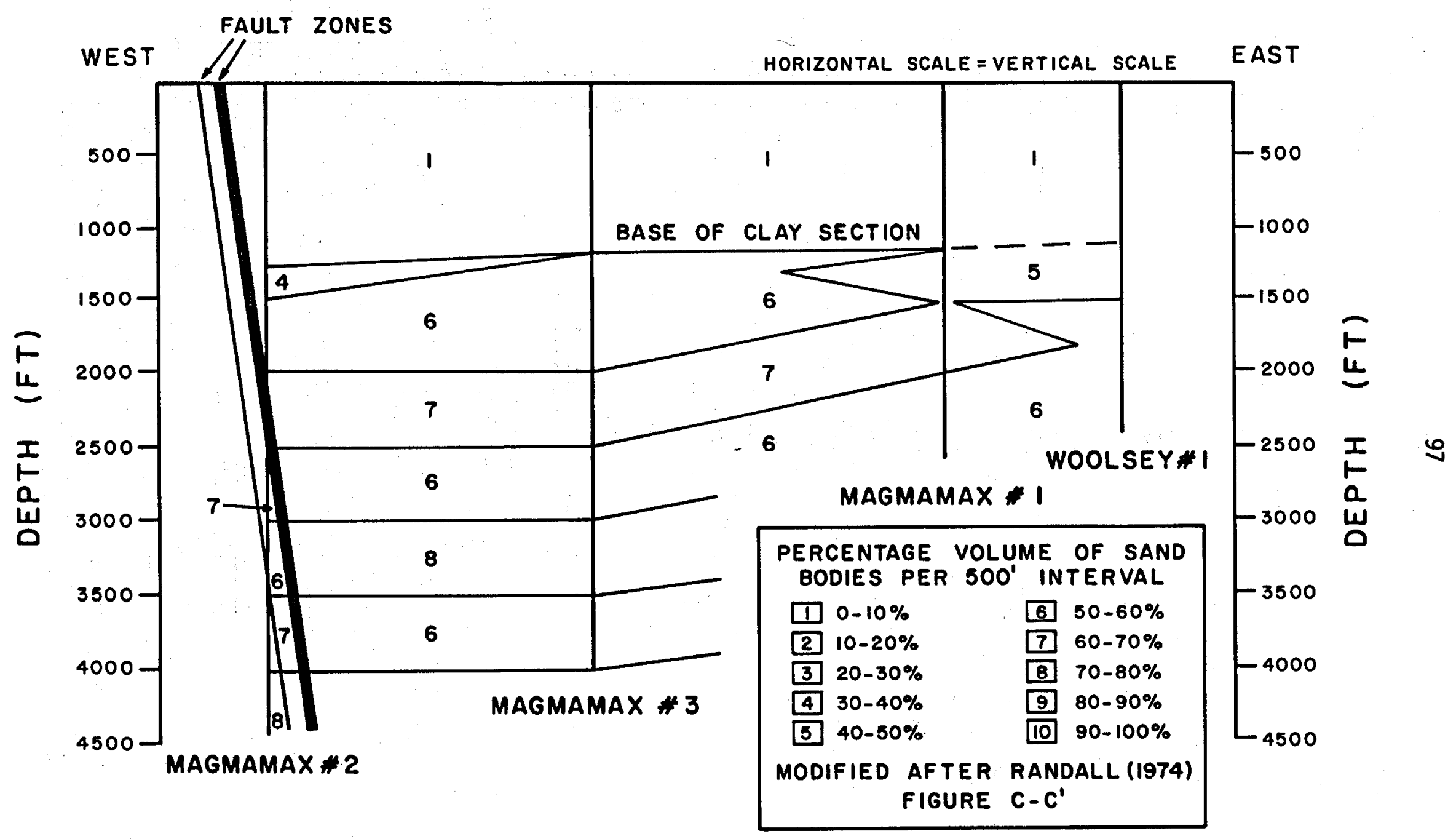

Figure 4-16. Parastratigraphy of the Buttes Area.

For well locations see Figure 4-1 (Source - Kendall, 1976, after kandall, 1974). 


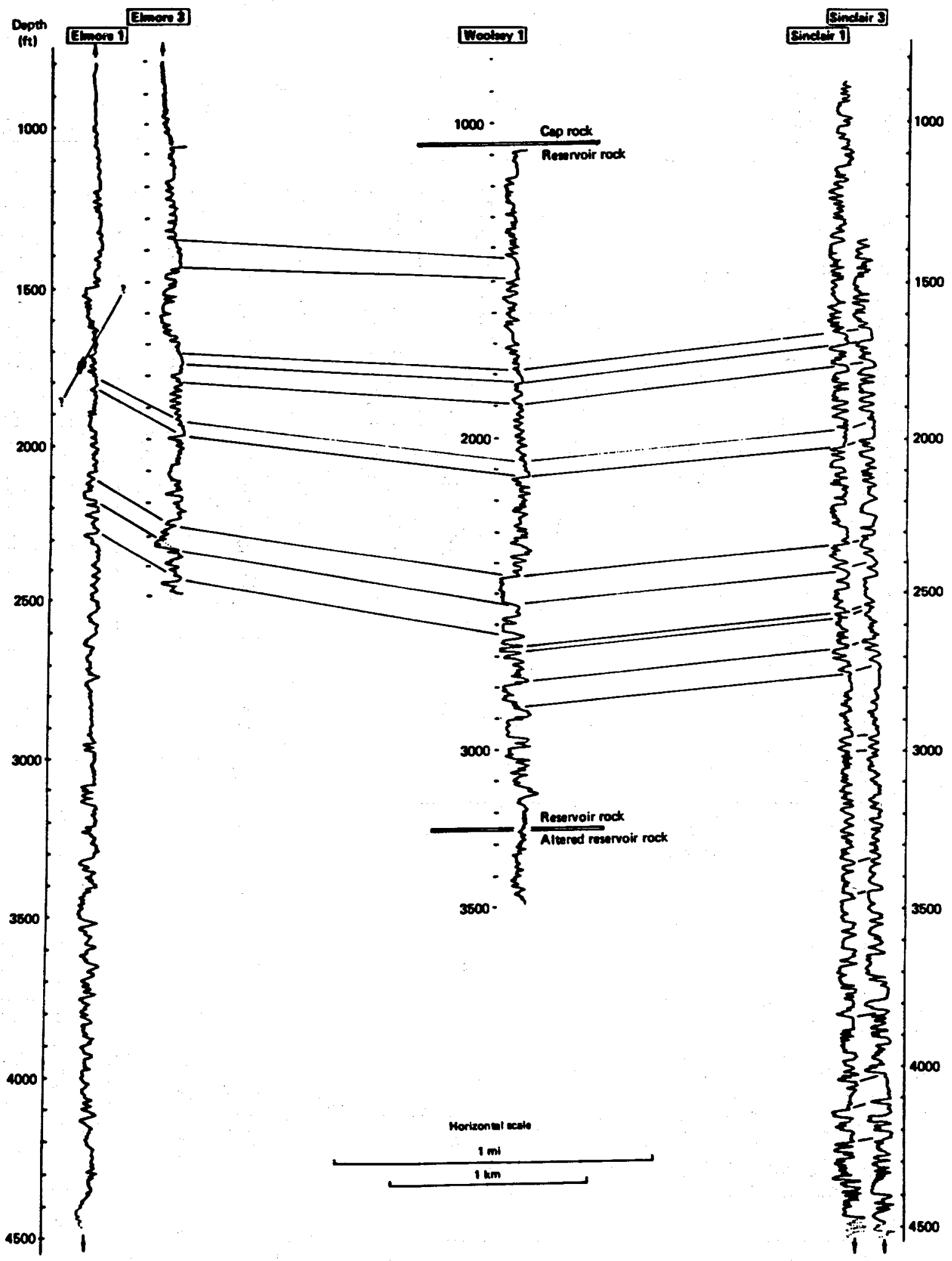

Figure 4-17. Spontaneous Potential (SP) Log Correlations of Five Wells Extending North to South from Elmore No. 1 to Sinclair No. 3 in the Salton Sea Geothermal Field.

(Source - Tewhey and Chan, 1977). 
(1974) therefore concluded that distance from a postulated magmatic heat source is almost the sole determining factor for the shape and size of the thermal anomaly.

\subsection{WATER/ROCK REACTIONS}

In response to elevated temperatures and the presence of concentrated brines, the sedimentary section within the SSGF undergoes a series of reactions and exchanges to form low grade metamorphic rocks with hornfelsic textures. The mineral and isotopic exchange reactions involved have been the subject of numerous studies since the pioneering work of Helgeson (1967, 1968). Among these are publications by Skinner et al, 1967; Doe et al, 1966; Muffler and White, 1968, 1969; Keith et al, 1968; Craig, 1966, 1969; Clayton et a1, 1968; Kendal1, 1976; Elders, 1977; Tewhey, 1977; Freckman, 1978; 01 son, 1978; Olson and Matlick, 1978; McDowell and McCurry, 1978; McDowell and Elders, 1979, 1980; McKibben, 1979; Bird and Norton, 1981. A recent review of the geochemistry of hydrothermal-magma systems in the U.S. states, "These studies, based largely on cuttings from several drill holes and to a lesser extent on drill cores, represent a major contribution to the understanding of hydrothermal processes in the continental crust" (A. White, 1980). This ongoing metamorphism in the SSGF represents an opportunity, rare in geology, to study metamorphic processes in a situation where the protolith is known and temperature, pressure, and fluid chemistry can be measured directly.

\subsubsection{Mineralogy of the Sediments of the Reservoir}

As indicated in section 4.4.1, the sediments consist of an upper clay-silt-evaporite lacustrine sequence and a lower complexly interbedded sandstone/siltstone/shale sequence. Apart from the effects of consolidation, diagenesis, and hydrothermal alteration, these rocks have textures, clastic mineralogy, and chemistry similar to Recent sediments of Lake Cahuilla and the Colorado River delta (Muffler and Doe, 1968; Van de Kamp, 1973). In the lower reservoir, original clastic mineralogy and textures can frequently still be recognized even in samples from an environment hotter than $300 \mathrm{C}$. 
In the central portion of the SSGF, in the Elmore No. 1 borehole, the boundary between the upper unit of unconsolidated lacustrine facies and the lower unit of consolidated deltaic facies occurs at $420 \mathrm{~m}$ depth. According to Kendall (1976), the average lower deltaic sequence is 25 percent sandstone, 5 percent siltstone, and 70 percent shale. Here the term "shale" is commonly used, somewhat loosely, for consolidated, usually laminated, but non-fissile mudstones.

The coarser-grained clastics consist of subangular to subrounded dominant quartz, plagioclase, and alkali feldspar; subordinate calcite, dolomite; and minor but varible amounts of Fe-Ti oxides, zircon, tourmaline, apatite, epidote, muscovite, biotite and leucoxene. Lithic clasts comprise less than a third of these sandstones and consist, in decreasing order of abundance, of chert, silicic volcanics, siltstone and shale, and metamorphic and plutonic rocks. Typical abundances of major clastic components of the sands include 66-77 percent quartz, 5-7.5 percent plagioclase, 6-9 percent alkali feldspar, 2-13 percent carbonate, $0-2.5$ percent layer silicates, 1 percent heavy minerals, and 3-12 percent lithic clasts (Van de Kamp, 1973). The argillaceous rocks consist of quartz, feldspar, montmorillonite, illite and kaolinite.

The upper part of the deltaic sequence immediately beneath the lacustrine caprock contains indurated shales and sandstones which are highly cemented by calcite and/or anhydrite (McDowell and Elders, 1980). In the shallowest part of the deltaic sequence the sandstones range from strongly cemented low porosity rock with 50 percent of available pore space filled with calcite to sandstones with porosities in the range 15-20 percent. These rocks at the top of the deltaic facies constitute an additional strongly cemented carbonate-rich cap to the geothermal system in the central part of the field. This carbonate-cemented cap, between the deeper deltaic reservoir below and the lacustrine rocks above, effectively extends the permeabilty barrier represented by the deposition of the clay-rich rocks above. This calcite precipitation required an influx of carbonate-saturated water beneath the sedimentary caprock. Carbonate saturation could occur in response to heating, which decreases carbonate solubility (Hoagland and Elders, 1978), or to the migration of carbon dioxide from deeper and hotter zones of the reservoir where decarbonation reactions are occurring. 


\subsubsection{Hydrothermal Alteration Textures}

The boundary between the carbonate cap and the deeper reservoir, which occurs at $440 \mathrm{~m}$ in Elmore No. 1 (McDowell and Elders, 1979), represents a major textural discontinuity. An abrupt increase in porosity of the sandstones to values near 20 percent is observed and the amount of carbonate cement is reduced by 50 to 75 percent. These changes are accompanied by initiation of alteration of detrital layer silicate minerals. This increase in porosity with increasing temperature allows a regular series of mineralogical, compositional, and textural changes to occur; these can be followed systematically to the highest temperatures yet penetrated by drilling. A regular prograde metamorphic zonation results. With increasing temperature, the formation of numerous authigenic minerals leads to strong recrystallization and reduction of porosity. Based upon petrographic examination of cuttings, therefore, three textural zones in the reservoir can be defined, which (in order of increasing temperature) are a low porosity carbonate cap, a zone of secondary porosity, and a low porosity hornfels zone (McDowell and Elders, 1979).

\subsubsection{Hydrothermal Mineral Zones}

Muffler and White (1969) made petrological studies on cuttings and deduced a number of metamorphic reactions in I.I.D. No. 1 and Sportsman No. 1. These wells each are about $1500 \mathrm{~m}$ deep and are north of the center of the field. Detrital montmorillonite converts to 111 ite-montmorillonite below 100 $\mathrm{C}$; the latter converts to illite at temperatures below $210 \mathrm{C}$. Ankerite forms by conversion of calcite and/or dolomite at temperatures as low as $100 \mathrm{C}$. Dolomite, ankerite, kaolinite, and $\mathrm{Fe}^{+2}$ (from brine) reacted to produce chlorite, calcite, and $\mathrm{CO}_{2}$ at temperatures below $180 \mathrm{C}$. Muffler and White (1969) also inferred that between 290 and $310 \mathrm{C}$, calcite, K-mica, quartz, and $\mathrm{Fe}^{+2}$ react to form $\mathrm{Fe}$-epidote and $\mathrm{K}$-feldspar with further release of $\mathrm{CO}_{2}$. Muffler and White (1968) had earlier proposed that these reactions were the sources of large amounts of $\mathrm{CO}_{2}$ at shallow levels in the Imperial Carbon Dioxide Gas Field mentioned in section 4.1.2. The high $\mathrm{CO}_{2}$ activity relative to $\mathrm{H}_{2} \mathrm{O}$ activity precluded zeolite formation in the SSGF. Above $300 \mathrm{C}$, the 
most common mineral assemblage reported by Muffler and White (1969) is quartz + Fe-epidote + chlorite $+K$-feldspar + albite $+K$-mica, with sporadic pyrite and hematite. Na-Ca plagioclase persists to the highest observed temperatures.

Subsequent detailed mineralogical and chemical studies of authigenic minerals were made by Kendall (1976), Tewhey (1977), McDowell and McCurry (1978) and McDowell and Elders (1980). The most detailed work has been performed on the Elmore No. 1 well, near the center of the field and the hottest well from which samples have been released for study. Figure 4-18 summarizes the authigenic minerals and temperatures found in this well. The figure also shows a simplified lithologic section based upon examination of cuttings. Because sandstones tend to be less indurated than shales, however, they are under-represented in drill cuttings relative to their true abundances. Where sandstone is present, there is usually a distinct break in grain size between the volumetrically dominant shale and the subordinate sandstone/siltstone. The average grain size of sandstones examined in thin section is $0.13 \mathrm{~mm}$ and ranges from 0.06 to $0.25 \mathrm{~mm}$.

The borehole was terminated at $2,169 \mathrm{~m}$ depth in a metarhyolite intrusive body; since chips of similar rhyolite occur in large concentrations in other restricted intervals, thin volcanic intrusive units are present elsewhere in the borehole (Robinson et al, 1976).

A temperature-depth profile for Elmore №. 1 (Figure 4-18) represents the mean of seven surveys over an eight month period in an undisturbed well (Helgeson, 1968). The working assumption that the reported weli temperatures are a good approximation of the actual geothermal gradient is supported by the agreement of measured well temperature and fluid inclusion-derived temperatures on both vein calcite and quartz grains recrystallized from sandstone (Freckman, 1978). The fluid pressure in this borehole is hydrostatic for the highly saline (25 to $30 \mathrm{wt}$ percent $\mathrm{NaCl}$ equivalent) brines observed in the SSGF and has a gradient of $0.098 \mathrm{bars} / \mathrm{m}$ (Helgeson, 1968). Thus the fluid pressure at the bottom of the borehole is 213 bars (McDowell and Elders, 1980).

The variation of the authigenic sheet silicate mineral assemblage in sandstone with depth and temperature is also summarized in Figure 4-18. Four 


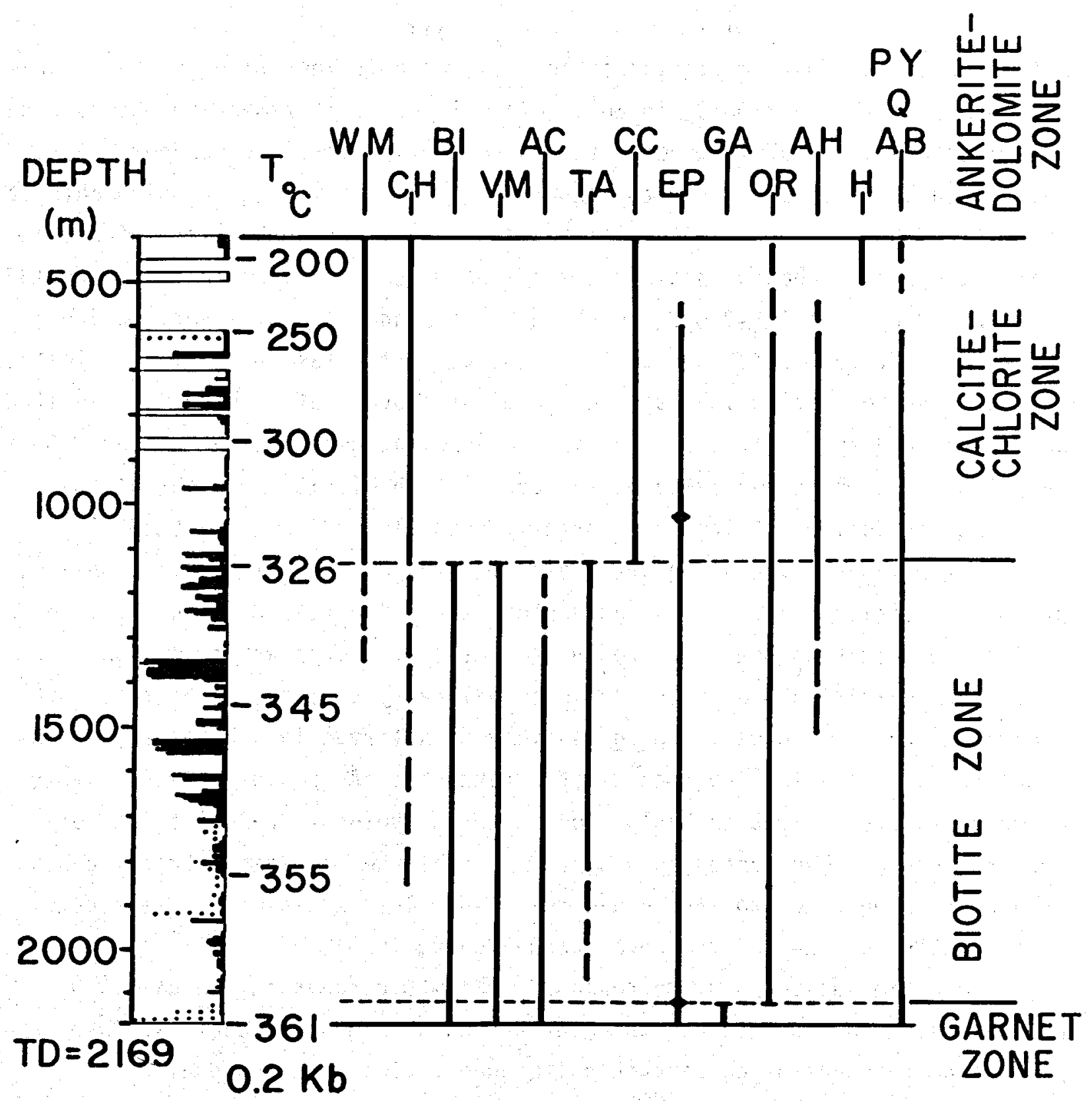

Figure 4-18. Summary of Lithologic, Temperature, Authigenic Mineral Variation, and Sandstone Mineral Zones in Elmore No. 1.

In the lithologic column, clear = shale; solid black = sand; and dots = volcanic material. Temperatures from Helgeson (1968). Vertical bars show depth range of authigenic minerals in sandstones: solid where common, dashed where sporadic and in minor quantities. Horizontal lines separate the major metamorphic zones. $\mathrm{WM}=$ illite and white mica; $\mathrm{CH}=$ chlorite; $B I=$ biotite; $V M=$ vermiculite in clay fraction; $A C=$ actinolite; $T_{A}=$ talc; $C C=$ calcite; $E P=$ epidote; $G A=$ garnet; $O R=$ orthoclase/microcline; $A H=$ anhydrite; $H=$ hematite; $P Y=$ pyrite; $Q=$ quartz; $A B=$ aibite (Source - McDowell and McCurry, 1978). 
metamorphic zones may be distinguished: (1) dolomite/ankerite zone at depths of $439 \mathrm{~m}$ or less and $<190 \mathrm{C}$, in which mixed layer illite/smectite occurs with dolomite/ankerite, calcite, hematite and possibly quartz and sphene; (2) calcite-chlorite zone, at 439 to $1135 \mathrm{~m}$ depth and 190-325 C, in which chlorite and illite/phengite occur with calcite, quartz, albite, orthoclase/microcline, epidote, pyrite, sphene, sphalerite, and anhydrite; (3) biotite zone, at 1135 to $2120 \mathrm{~m}$ depth and $325-360 \mathrm{C}$, in which biotite and clay-size vermiculite occur, at different depths, with talc, quartz, orthoclase/microcline, albite, epidote, pyrite, actinolite, sphene and minor amounts of muscovite, chlorite, anhydrite, and sphalerite; and (4) garnet zone, at depths greater than $2155 \mathrm{~m}$ and $>360 \mathrm{C}$, in which andradite garnet occurs with biotite, quartz, albite, epidote, actinolite, pyrite, and sphene (McDowell and Elders, 1980).

The framework minerals quartz, alkali feldspar, and plagioclase show well preserved detrital morphologies at depths near $439 \mathrm{~m}$ (190 C). In the interval 620 to $925 \mathrm{~m}$ (250 to $308 \mathrm{C}$ ), through processes of overgrowth formation, pore filling by calcite and epidote, and eventual recrystallization of framework minerals, the sandstones are progressively transformed into hornfelsic rocks with strongly interlocking granoblastic textures. At depths of $1100 \mathrm{~m}(320 \mathrm{C})$ or more, recrystallization has proceeded to the point where all traces of overgrowths have been annealed away and most of the original detrital grains have been homogenized to authigenic textures. The resulting hornfels persist to the bottom of the well (McDowell and Elders, 1980).

The estimated porosity decreases from 15-20 percent in the calcitechlorite zone to 5 percent in the biotite zone. A general decrease in open pore space through the calcite-chlorite zone reflects the gradual recrystallization of the sandstone as the biotite "isograd" is approached. The estimated porosity remains at approximately 5 percent to the bottom of the well, in the garnet zone (McDowell and Elders, 1980).

The overall progression of mineral assemblages in both sandstone and shale is 1isted in Table 4-9 (McDowell and Elders, 1980). Several authigenic minerals additional to those described by Muffler and White (1969) are present. These minerals include vermiculite, talc, anhydrite, and andradite garnet. Changes in phyllosilicates which accompany the progressive alteration are also summarized in Table 4-9. In the dolomite/ankerite zone in sandstones, the phyllosilicates are illite/mixed layer phase with 10 percent 
Table 4-9. Summary of Authigenic Mineral Assemblages, Elmore No. 1, Salton Sea Geothermal Field

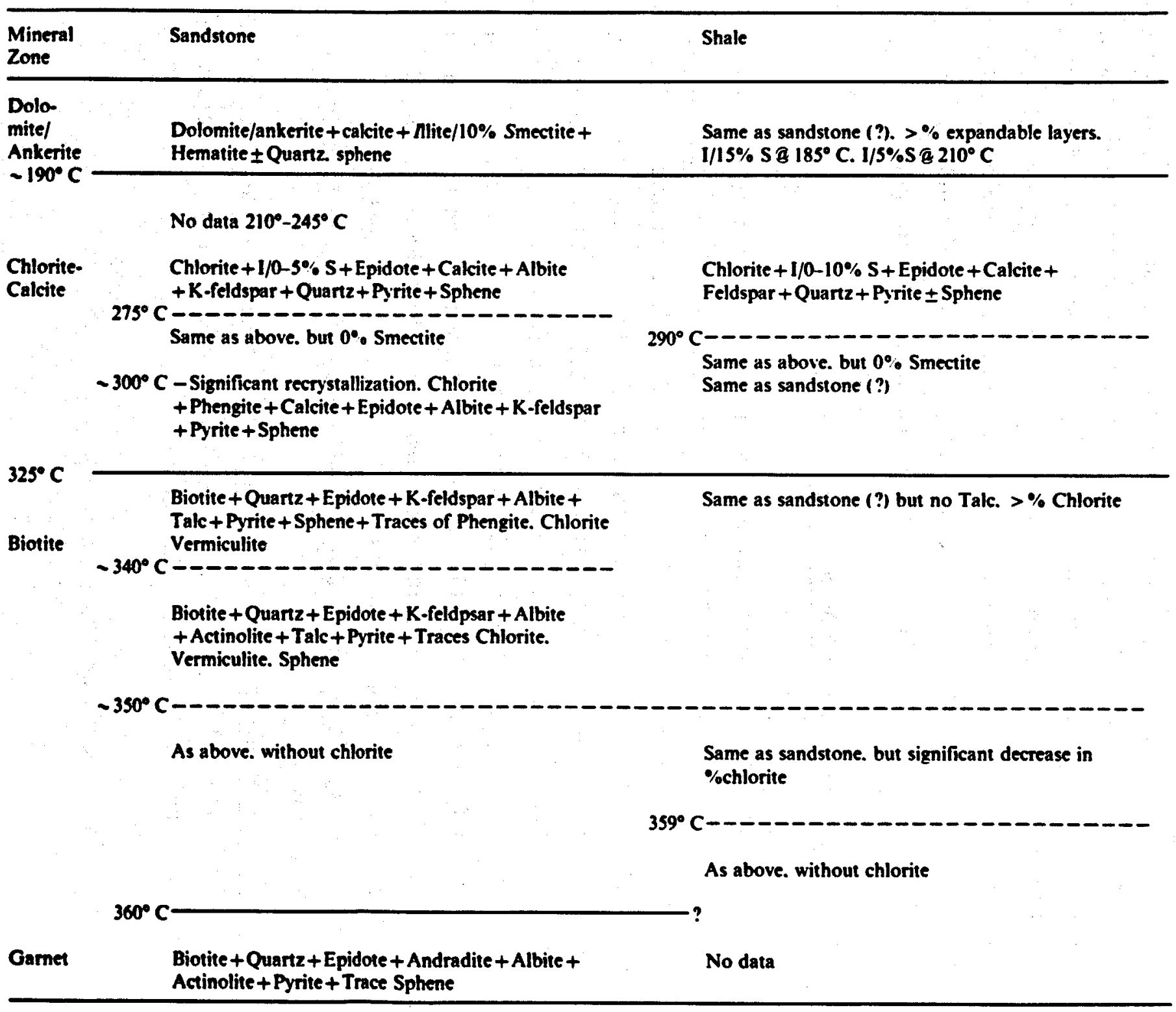

(Source - McDowell and Elders, 1980). 
expandable layers ( $1 / 10 \% \mathrm{~S})$ whereas in shales the percentage of expandable layers in the mixed layer phase changes from $10-15$ percent at $185 \mathrm{C}$ to 5 percent at $210 \mathrm{C}(\mathrm{I} / 15 \%$ to $\mathrm{I} / 5 \%)$. In the chlorite/calcite zone, where epidote is also abundant, the layer sillicates become a mixture of illite and chlorite. With increasing temperatures in this zone the illite recrystallizes to phengitic white mica. Throughout the biotite zone and into the garnet zone the biotite undergoes compositional changes from a siliceous, K-deficient biotite to a typical low-grade metamorphic biotite. Chlorite completely disappears from sandstone at approximately $350 \mathrm{C}$ and abruptly diminishes in amount in the more chloritic shales at the same temperature.

\subsubsection{Phase Relations of Authigenic Minerals}

Although the reactions between the brines and rocks to produce these alteration assemblages can be described in terms of the complex system $\mathrm{Na}_{2} \mathrm{O}-\mathrm{K}_{2} \mathrm{O}-\mathrm{CaO}-\mathrm{MgO}-\mathrm{FeO}_{-} \mathrm{Fe}_{2} \mathrm{O}_{3}-\mathrm{Al}_{2} \mathrm{O}_{3}-\mathrm{SiO}_{2}-\mathrm{CO}_{2}-\mathrm{HCl}-\mathrm{S}-\mathrm{H}_{2} \mathrm{O}$, various simpl ifying assumptions must be made in order to proceed. For example, Younker et al (1982) used the simpler subsystem $\mathrm{CaO}-\mathrm{Al}_{2} \mathrm{O}_{3}-\mathrm{SiO}_{2}-\mathrm{CO}_{2}-\mathrm{H}_{2} \mathrm{O}$ and considered the isobaric phase relations as a function of temperature and mole fraction of $\mathrm{CO}_{2}$, assuming $\mathrm{P}_{\mathrm{fl}}$ uid $=2 \mathrm{kbar}$ (10 times higher than the observed fluid pressure in Elmore No. 1 wel1). A more rigorous approach was taken by Bird and Norton (1981) who performed thermodynamic calculations of compositional relations among aqueous solutions and minerals in the system $\mathrm{Na}_{2} \mathrm{O}-\mathrm{K}_{2} \mathrm{O}-\mathrm{CaO}-\mathrm{MgO}_{-}-\mathrm{Fe}_{2} \mathrm{O}_{3}-\mathrm{Al}_{2} \mathrm{O}_{3}-\mathrm{SiO}_{2}-\mathrm{CO}_{2}-\mathrm{HCl}-\mathrm{H}_{2} \mathrm{O}$. Among the reactions they considered were:

Chlorite + calcite zone assemblage consisting of epidote solid solution, illite/phengite, albite, sanidine, calcite, and an aqueous solution, which is represented by the following reactions*:

(Equations begin on the next page)

* The phase is written above the chemical formula; in the cases where solid solutions occur, the component is written beneath the formula. 


$$
\begin{aligned}
& \text { feldspar fllite/phengite } \\
& 3 \mathrm{NaAl} \mathrm{Si}_{3} \mathrm{O}_{8}+\mathrm{NaAl}_{2}\left(\mathrm{AlSi}_{3} \mathrm{O}_{10}\right)(\mathrm{OH})_{2}+4 \mathrm{H}^{+} \\
& \text {albite paragonite } \\
& \text { illite/phengite } \\
& \text { * } 3 \mathrm{Al}_{2} \mathrm{Si}_{4} \mathrm{O}_{10}(\mathrm{OH})_{2}+4 \mathrm{Na}^{+} \text {, } \\
& \text { pyrophyllite } \\
& \text { feldspar illite/phengite } \\
& 3 \mathrm{KAISi} \mathrm{O}_{3}+\mathrm{KAl}_{2}\left(\mathrm{AlSi}_{3} \mathrm{O}_{10}\right)(\mathrm{OH})_{2}+4 \mathrm{H}^{+} \\
& \text {sanidine muscovite } \\
& \text { illite/phengite } \\
& =3 \mathrm{Al}_{2} \mathrm{Si}_{4} \mathrm{O}_{10}(\mathrm{OH})_{2}+4 \mathrm{~K}^{+} \text {, } \\
& \text { pyrophyllite }
\end{aligned}
$$

feldspar illite/phengite

$$
\mathrm{KAl} \mathrm{Si} \mathrm{O}_{8}+\mathrm{Al}_{2} \mathrm{Si}_{4} \mathrm{O}_{10}(\mathrm{OH})_{2}
$$$$
\text { sanidine pyrophyllite }
$$

$$
\text { illite/phengite }
$$

$$
\neq \mathrm{KAI}_{2}\left(\mathrm{AlSi}_{3} \mathrm{O}_{10}\right)(\mathrm{OH})_{2}+4 \mathrm{SiO}_{2}(\mathrm{aq}) \text {, }
$$

$$
\text { muscovite }
$$

$$
\begin{array}{cl}
\text { epidote } & \text { feldspar } \\
2 \mathrm{Ca}_{2} \mathrm{Al}_{3} \mathrm{Si}_{3} \mathrm{O}_{12}(\mathrm{OH}) & + \\
\text { clinozoisite } & \text { 3KAlSi } \mathrm{SO}_{3} \mathrm{O}_{8}
\end{array}+8 \mathrm{H}^{+}
$$

illite/phengite

$$
\neq \underset{\text { muscovite }}{3 \mathrm{KAI}_{2}\left(\mathrm{AlSi}_{3} \mathrm{O}_{10}\right)(\mathrm{OH})_{2}}+6 \mathrm{SiO}_{2}(\mathrm{aq})+4 \mathrm{Ca}^{2+}+2 \mathrm{H}_{2} \mathrm{O} \text {, }
$$

calcite

$$
\mathrm{CaCO}_{3}+2 \mathrm{H}^{+}+\mathrm{Ca}^{2+}+\mathrm{CO}_{2}(\mathrm{~g})+\mathrm{H}_{2} \mathrm{O}
$$

Biotite zone assemblage consisting of epidote solid solution, albite, sanidine/K-feldspar, biotite, tremolite solid solution, quartz, and an aqueous solution, which is represented by the reactions 


$$
\begin{array}{ll}
\underset{\mathrm{NaAlSi}}{\text { feldspar }} & \mathrm{feldspar} \\
\text { albite } & \mathrm{KAlSi}_{3} \mathrm{O}_{8}
\end{array}+\mathrm{Na}^{+},
$$

biotite

$\mathrm{KMg}_{3}\left(\mathrm{AlSi}_{3} \mathrm{O}_{10}\right)(\mathrm{OH})_{2}+6 \mathrm{H}^{+}$

phlogopite

feldspar

* KAl $\mathrm{Si}_{3} \mathrm{O}_{8}+3 \mathrm{Mg}^{2}+4 \mathrm{H}_{2} \mathrm{O}$,

K-feldspar

$$
\begin{array}{cc}
\text { feldspar } & \text { amphibole } \\
5 \mathrm{KAlSi} \mathrm{O}_{3} & +3 \mathrm{Ca}_{2} \mathrm{Mg}_{5} \mathrm{Si}_{8} \mathrm{O}_{22}(\mathrm{OH})_{2}+12 \mathrm{H}^{+} \\
\begin{array}{c}
\text { K-feldspar } \\
\text { tremolite }
\end{array} & \text { biotite } \\
+5 \mathrm{KMg}_{3}\left(\mathrm{Al} \mathrm{Si}_{3} \mathrm{O}_{10}\right)(\mathrm{OH})_{2}+6 \mathrm{Ca}^{2+}+24 \mathrm{SiO}_{2}(\mathrm{aq}) & +4 \mathrm{H}_{2} \mathrm{O}, \\
\text { phlogopite } &
\end{array}
$$

epidote

$$
\begin{aligned}
& \mathrm{Ca}_{2} \mathrm{Al}_{3} \mathrm{Si}_{3} \mathrm{O}_{12}(\mathrm{OH})+6 \mathrm{SiO}_{2}(\mathrm{aq})+3 \mathrm{Na}^{+}+\mathrm{H}^{+} \\
& \text {clinozoisite }
\end{aligned}
$$

$$
\begin{aligned}
& \text { feldspar } \\
& +3 \mathrm{NaAl} \mathrm{Si}_{3} \mathrm{O}_{8}+2 \mathrm{Ca}^{2+}+\mathrm{H}_{2} \mathrm{O} \text {. } \\
& \text { albite }
\end{aligned}
$$

Using the mass action equations for the reactions 1 to 5 , together with the activities of components of solid solutions and assuming unit activity for albite, alkali feldspar, calcite, and water allowed calculation of $a_{\mathrm{Na}}+/ \mathrm{a}_{\mathrm{H}^{+}}$, ${ }^{a} \mathrm{~K}^{+/ a} \mathrm{H}^{+},{ }^{a} \mathrm{Ca}^{2}+/ \mathrm{a}^{2} \mathrm{H}^{+},{ }^{a} \mathrm{SiO}_{2}(\mathrm{aq})$, and $\mathrm{f}_{\mathrm{CO}_{2}}$ in the fluid phase as a function of

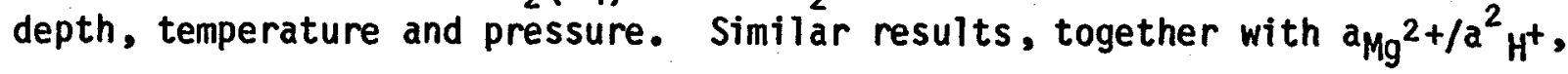
were also obtained by considering equations 6 to 8. Calculations were also performed for the garnet zone assemblage of garnet, biotite, epidote solid solution, quartz, and aqueous solution. 
Bird and Norton's (1981) calculations showed that, in the upper $2.5 \mathrm{~km}$ of the SSGF, there are systematic gradients in the activity ratios of the alkali and alkaline earth cations to hydrogen ions and in the fugacity of $\mathrm{CO}_{2}(\mathrm{~g})$. The calculated values were in remarkably close agreement to the measured solute concentrations in the geothermal fluids produced by the wells. Near Elmore No. 1, $a_{N a}+/ a_{H^{+}}$and $a_{K}+/ a_{H^{+}}$vary several tenths of a log unit from 250 to $350 \mathrm{C}$, whereas ${ }^{a} \mathrm{Ca}^{2}+/ \mathrm{a}^{2} \mathrm{H}^{+}$decreases two orders of magnitude over the same range. The fugacity of $\mathrm{CO}_{2}$ gas is 1.5 bars at $\leq 310^{\circ} \mathrm{C}$. Uncertainties exist both in these calculations and in the measurements of temperatures and fluid compositions. However, Bird and Norton (1981) conclude that the close agreement between the predicted and observed characteristics of these geothermal fluids suggests that these uncertainties do not materially affect their final calculations.

\subsubsection{Ore Mineralization in the SSGF}

The high concentration of metals in the brines of the SSGF referred to in section 4.3 makes the brines themselves of interest as potential sources of metal. More minerals are widespread in the deeper part of the system as incipient sulfide and oxide mineralization accompanies the mineral reactions referred to in section 4.5.4. A recent study on economic mineralization in the SSGF by McKibben (1979) was based primarily upon studies of the cuttings from the River Ranch No. 1 well and comparisons with other wells in the north-central part of the field. At depth, ore minerals are more abundant in shales than sandstones.

Major ore minerals found are, in order of decreasing abundance: pyrite, hematite, sphalerite, chalcopyrite, pyrrhotite, marcasite, and galena. Ore mineralization was divided by McKibben (1979) into three main types: diagenetic sulfide mineralization, occurring at depths less than $760 \mathrm{~m}$ and temperatures less than $250^{\circ} \mathrm{C}$; (2) metamorphic sulfide mineralization, occurring at depths greater than $760 \mathrm{~m}$ and temperatures greater than $250^{\circ} \mathrm{C}$; and (3) vein-related sulfide and oxide mineralization, occurring chiefly in restricted intervals at depths greater than $760 \mathrm{~m}$.

Diagenetic mineralization consists of fine-grained iron sulfides occurring as cement in sandstone and as disseminated layers in shale formed by alteration of early-formed framboidal iron sulfides to marcasite and pyrite. 
Minor amounts of sphalerite, chalcopyrite, and galena also occur as cement intergrown with these iron sulfides.

Metamorphic mineralization here refers to the progressive development of porphyroblastic pyrite with increasing depth and temperature, its replacement by pyrrhotite, chalcopyrite, sphalerite, and galena at depths greater than $1200 \mathrm{~m}$, and its decomposition into skeletal aggregates at depths greater than $1500 \mathrm{~m}$ concurrent with the hornfelsic recrystallization of the host sediments referred to in section 4.5.3.

Vein-filling and related pore-filling mineralization is of two contrasting types: (1) hematite-dominated; and (2) sulfide-dominated. The hematite-dominated type occurs as the assemblage hematite + quartz + chalcopyrite + pyrite, or the assemblage hematite + epidote + anhydrite + chalcopyrite + pyrite. Both assemblages occur as open, porous veins in a single vertical zone at least $220 \mathrm{~m}$ thick in River Ranch No. 1. Sulfide-dominated vein mineralization occurs as the variable assemblage sphalerite + chalcopyrite + calcite + epidote + quartz + adularia + galena + anhydrite at depths less than $1170 \mathrm{~m}$, and as the variable assemblage pyrrhotite + calcite + sphalerite + chalcopyrite at depths greater than $1190 \mathrm{~m}$. All sulfide-dominated veins are sealed and occur in relatively restricted vertical intervals (McKibben, 1979).

Thermodynamic analysis of the ore mineral vein assemblages and brine analyses indicates that the modern reservoir brines are in equilibrium with the open, porous hematite-dominated vein assemblage at $300^{\circ} \mathrm{C}$, with $\mathrm{pH}=5.4$ and $\log \mathrm{f}_{2}=-30$. Calculated metal-chloride complex solubilities for $\mathrm{Cu}, \mathrm{Pb}$ and $\mathrm{Zn}$ also agree well with the brine analyses (McKibben, 1979).

Phase relations of the presently-sealed sulfide-dominated vein assemblages require that earlier fluids, if formed at the same temperature and $\mathrm{pH}$, had to be more reduced and more sulfur-rich than the present slightly more oxidized, sulfur-poor brines. Early compaction-related, intrabasinal fluids may have been responsible for the sulfide-dominated assemblages, while the hematite-dominated assemblages and present brines may represent lateral influx of later, more surficial waters, such as partly evaporated and reacted Colorado River water (Mckibben, 1979).

Textures of the ore minerals in the SSGF indicate that early-formed diagenetic iron sulfides play an important role as nuclei and sources of 
sulfur and iron for later diagenetic, metamorphic, and hydrothermal sulfide and oxide mineralization (McKibben, 1979). Most later Cu-Pb-Zn sulfides and iron oxides replace earlier diagenetic and porphyroblastic pyrite, and the latter are commonly enveloped and resorbed by veins. Intragranular replacement textures involving pyrite porphyroblasts require that $\mathrm{Cu}, \mathrm{Pb}$, and Zn be derived mainly from brines in the immediately-surrounding sediments. Thus this system, as presently explored, is an incipient stratabound sulfide deposit which is being overprinted by hydrothermal and metamorphic processes. Sulfide precipitation is apparently controlled by accessibility of metal-rich but sulfur-poor brines to earlier-formed pyrite sulfur (McKibben, 1979).

As indicated by Mckibben (1979), textural evidence suggests that the major source of $\mathrm{Cu}, \mathrm{Pb}$ and $\mathrm{Zn}$ in the brines is by leaching of the shales (see section 4.3.4). From the brine analyses in section 4.3.1, the total concentration of ore metals in the brine exceeds total sulfur by a factor of eight on a molal basis, with the brine apparently saturated with respect to sulfide. The origin of sulfur in this system is not entirely understood. The sulfur in early-formed synsedimentary/diagenetic iron sulfides is probably derived from inorganic sulfate that has been reduced by bacterial action. The occurrence of sulfate-rich evaporites in the shallow sedimentary sequence suggests that sulfate was transported in solution in Colorado River water and concentrated in the Salton Basin. As pointed out by White (1981), a clustering of $\delta^{34} \mathrm{~S}$ values near the meteorite standard tends to support a magmatic source, either directly or by erosion of igneous rocks with primitive isotopic ratios (see section 4.3 .3 ).

\subsubsection{Light Stable Isotopes in the Sediments of the SSGF}

The $\delta D$ and $\delta^{18} 0$ ratios of the groundwaters in the Imperial valley and in the SSGF were discussed in sections 3.7 .1 and 4.3 .2 , respectively. Studies have also been made of the exchange of these isotopes between the brines and reservoir rocks. For example, Clayton et al (1968) found that subsurface rocks in the SSGF are progressively depleted in ${ }^{18} 0$ with increasing temperature. They proposed a single $\delta^{18} 0$ value of +2 per mil for geothermal brines from the central reservoir, i.e., that the brines are well mixed isotopically. Later, 01 son (1978) compared $\delta^{18} 0$ of vein calcites from eight 
wells in the SSGF. Even though all these calcite samples were from depths corresponding to the same ambient temperature of $250 \mathrm{C}$, they showed a variation of 4 per $\mathrm{mil}$ in $\delta^{18} 0$ which he attributed to variations in $\delta^{18} 0$ of waters in the field.

Kendall (1976) studied in detail three wells in the Buttes area of the SSGF and carefully interrelated isotopic and petrological studies. The wells studied were Magmamax No. 2, Magmamax No. 3, and Wool sey No. 1, which have maximum temperatures of $320 \mathrm{C}$ at $1340 \mathrm{~m}$ depth. Kendall (1976) found that extensive oxygen and carbon isotope exchange has occurred between geothermal brines and country rock. Detrital and diagenetic carbonates have exchanged with the brines at temperatures as low at 100-150 C. Both detrital and authigenic quartz. in dense, highly altered and mineralized sandstones have completely or almost completely exchanged at temperatures as low as $290 \mathrm{C}$. Hydrothermal epidote $\delta^{18} 0$ values are approximately 4 per mil lighter than coexisting quartz. Hydrothermal hematite is apparently in oxygen isotopic equilibrium with quartz at measured borehole temperature $(\sim 300 \mathrm{C})$.

Superimposed on the general trend of lower $\delta^{18} 0$ values at increasing temperature is another important effect due to permeability variations in reservoir rocks (Kendall, 1976). A pattern of multiple inversions is observed in plots of calcite $\delta^{18} 0$ versus depth in adjacent wells. The locations of these inversions is apparently stratigraphically controlled and can be correlated from well to well. Aquifers are characterized by low delta values, and aquitards by high values. The $\delta^{18} 0$ values of ve in calcite are $0-1$ per mil lighter than those of calcite cement in sandstones, which in turn are 1-7 per mil lighter than those of calcite in shale. Hydrothermal alteration is more intensive in zones characterized by low delta values and in mineral assemblages that differ significantly from those of less permeable horizons. Kendall (1976) inferred that aquifer permeability is predominantly secondary and that lithologic variation has a strong control over creation of microfractures. Water circulation is largely restricted to the horizontal aquifers, which Kendall (1976) correlated between wells using $\delta^{18} 0$ values. Kendall also suggested that fluids within veins are locally derived and vertical fractures have been relatively unimportant as circulation channels.

This last finding seems at first sight to be at variance with the earlier conclusions of Randall (1974), whose data seem to show that isothermal 


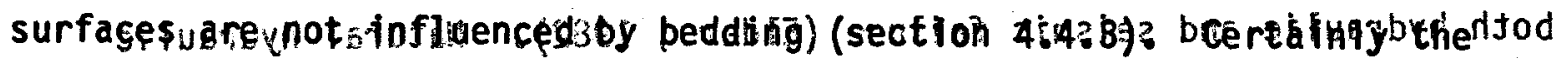

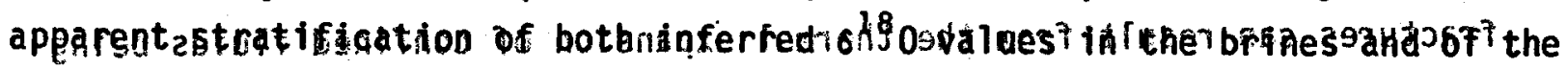

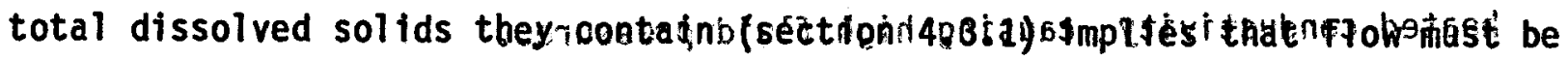

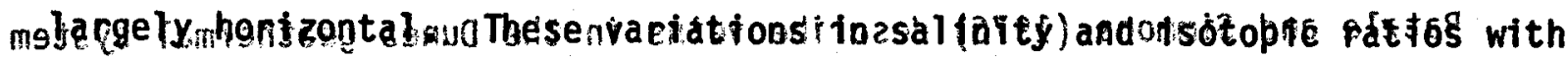

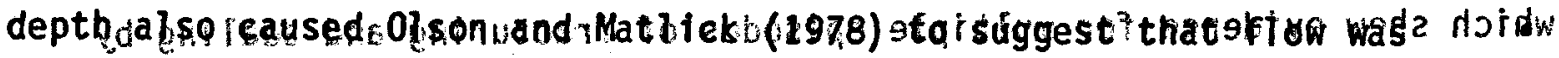

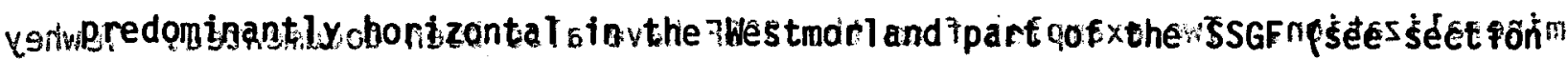

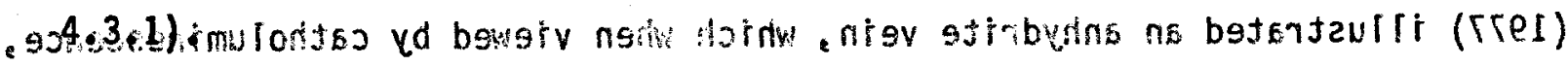

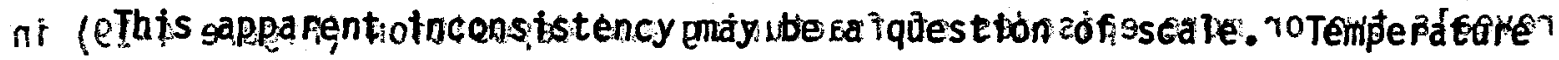

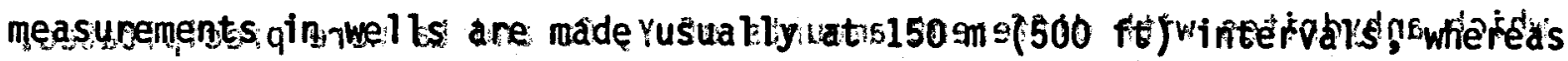

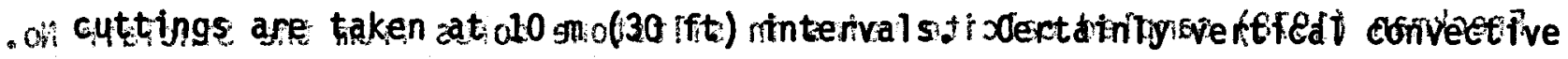

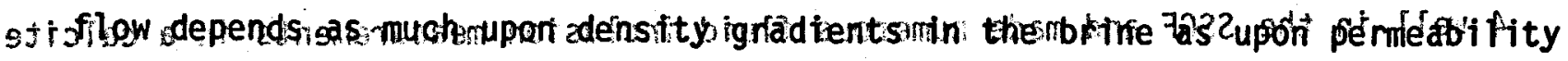

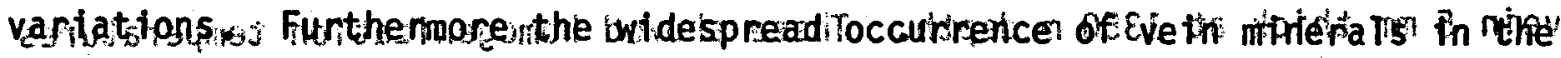

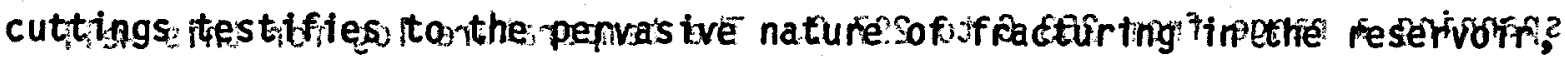

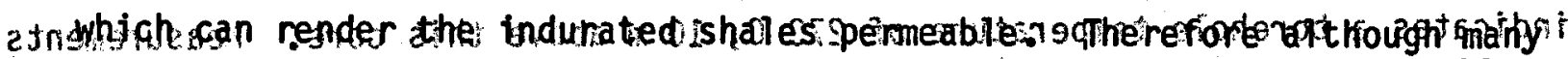

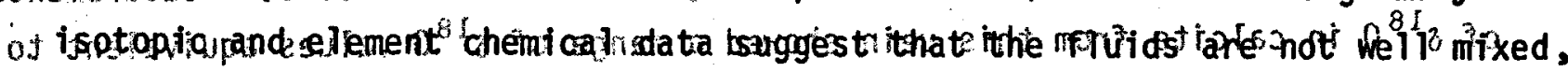

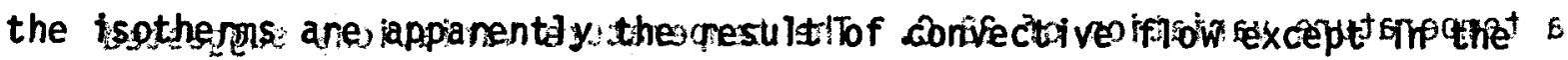

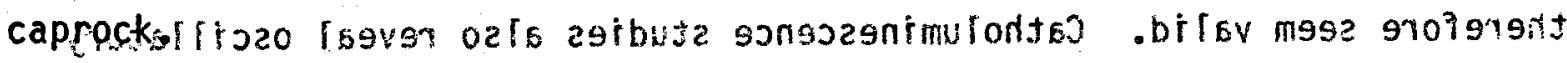

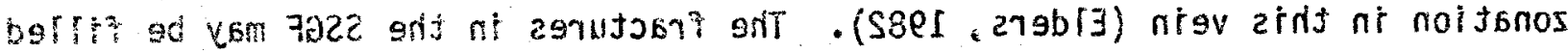

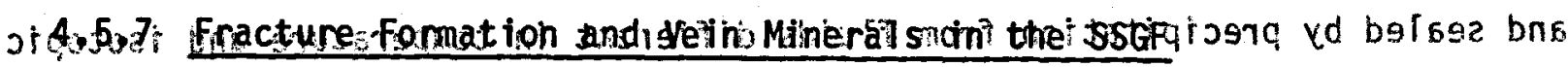

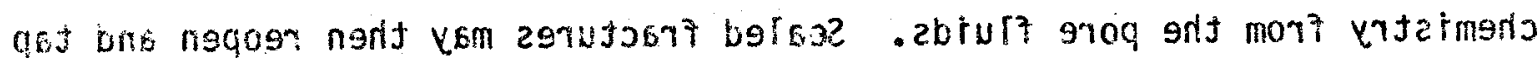

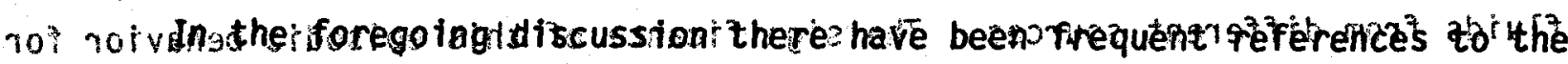

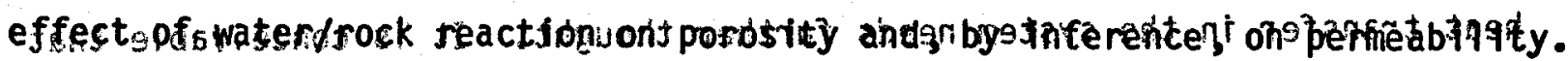

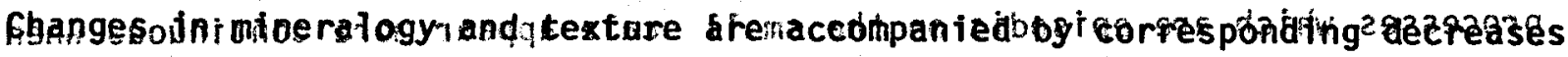

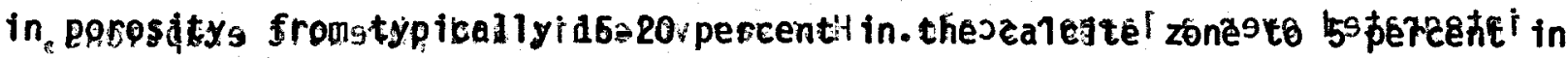

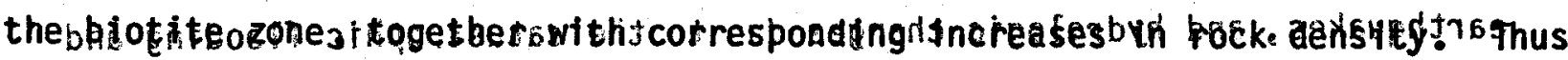

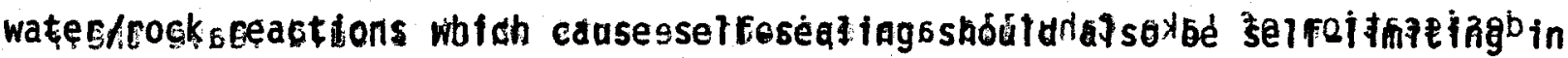

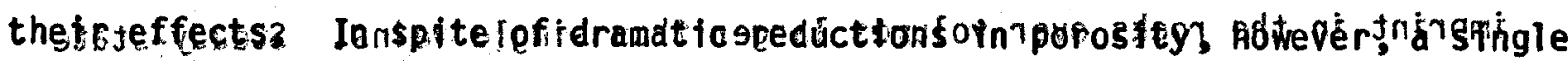
gwetl sfan nproduce rbundreds of tonnes gdf bnine satanhodrzzsm bn6 5 sed to 2 l9bom

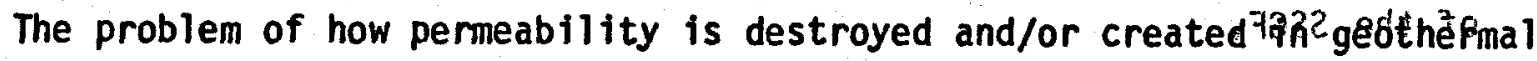
systems has been discussed recently by Elders $(1981,1982)$. As porosity is

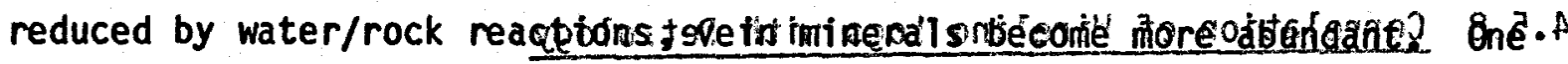
result of increased temperature is that matrix permeability declines and

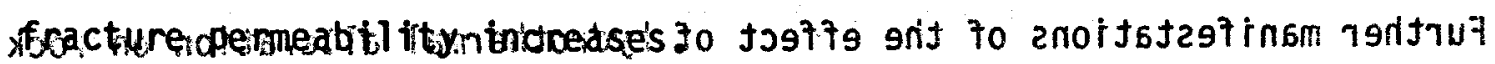

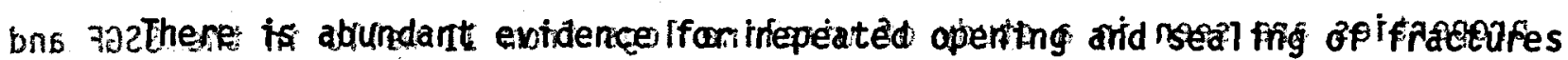

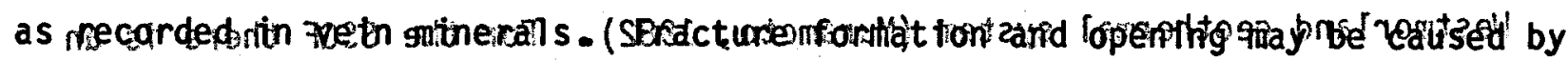


both hydraulic and seismic failure (Elders, 1982). Natural hydraulic fractures can result from the themal expansion of confined fluids being heated conductivity, causing high fluid pressures.

Batzle and Simmons (1976) describe veins in the Dunes geothermal system which show evidence for multiple episodes of fracturing and sealing by mineralization. Two examples from the SSGF have also been documented. Tewhey (1977) illustrated an anhydrite vein, which when viewed by catholuminescence, reveals two or more episodes of fracturing and deposition (Figure 4-19) in which anhydrites with different amounts of $Y, C e$ and La were precipitated. Freckman (1978) sampled calcite veins in siltstone cores from the Sinclair No. 4 well in the SSGF and made numerous fluid inclusion measurements in a calcite vein $5 \mathrm{~mm}$ thick at $1350 \mathrm{~m}$ depth. These showed homogenization temperatures spanning a range from $253 \mathrm{C}$ to $297 \mathrm{C}$. The temperature $\log$ for this well indicates a borehole temperature of $273 \mathrm{C}, 10 \mathrm{~m}$ above this core. Measurements of $\delta^{18} 0$ in calcite from this vein showed a range of $\delta^{18} 0$ values equivalent to a temperature variation of $33 \mathrm{C}$. The temperature variations suggested therefore seem valid. Catholuminescence studies also reveal oscillatory zonation in this vein (Elders, 1982). The fractures in the SSGF may be filled and sealed by precipitation from fluids different in temperature and isotopic chemistry from the pore fluids. Sealed fractures may then reopen and tap fluids from different sources. The significance of this episodic behavior for heat transfer in the system needs further thought. It is conceivable that processes which are episodic on the small scale appear more continuous when integrated over a larger scale. However volcanic and phreatic eruptions, earthquakes, and hydrologic changes due to the catastrophic flooding and desiccation of Lake Cahuilla are episodic events. which should leave their imprint in the rocks over volumes larger than single veins. Steady-state models of heat and mass transfer may therefore be too simplistic in the case of the SSGF.

\subsubsection{Correlation of Wireline Logs with Petrology}

Further manifestations of the effect of hydrothermal alteration on rock properties are seen in a study of wireline logs from 11 wells in the SSGF and Westmorland geothermal system (Muramoto, 1982). For the SSGF there is an 


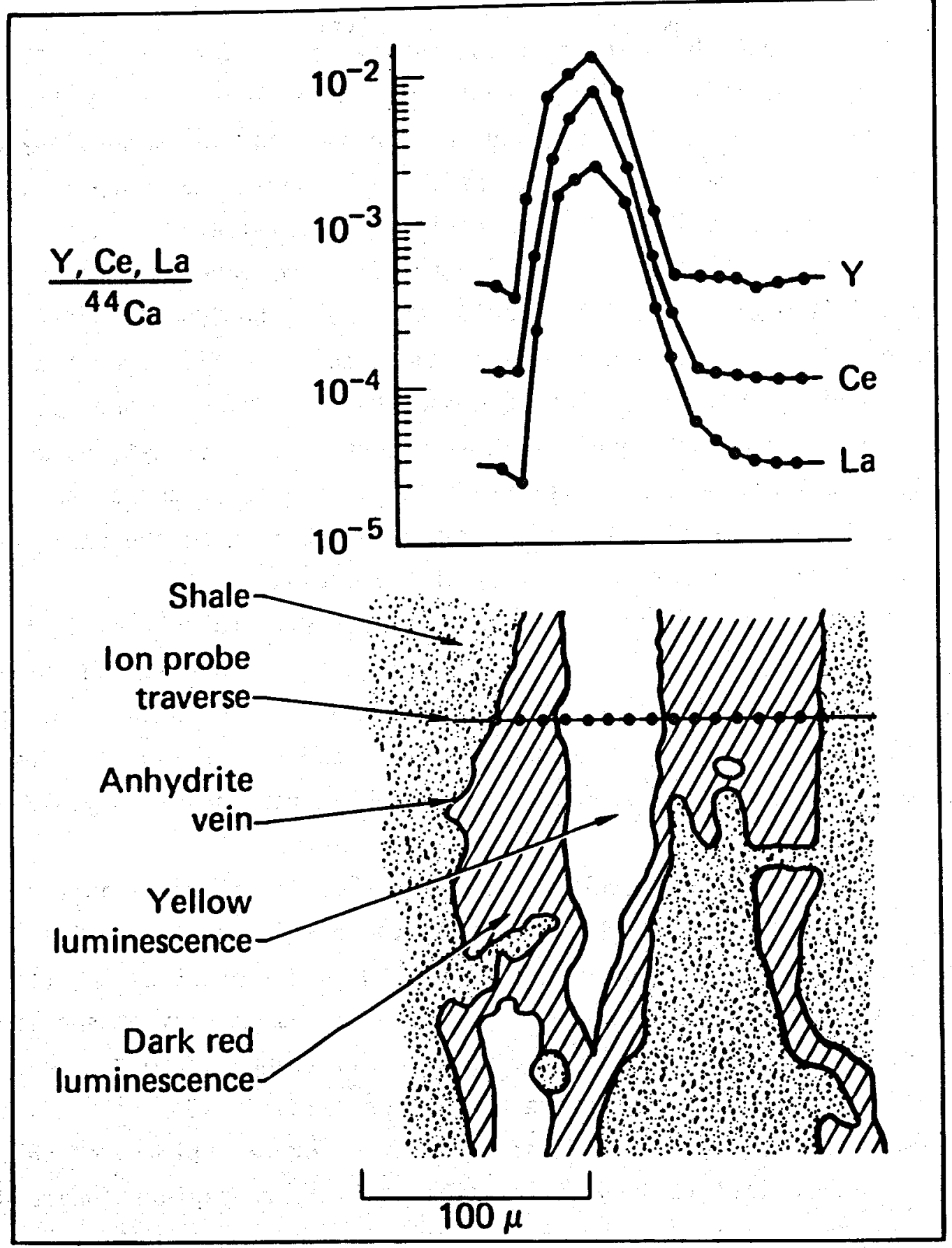

Figure 4-19. Calcite and Epidote Veins in Shale from $900 \mathrm{~m}$ Depth in the Salton Sea Geothermal Field.

Ion-microprobe traverses were made across zoned anhydrite grains to determine the geochemical basis for differences in

Iuminescent intensity. The position of data points in the graph is shown on the ion-microprobe transverse. Positive concentration-anomalies of $Y, C e$, and La correspond to zones of yellow luminescence (Source - Younker et al, 1982). 


\section{$196^{5}$}

evident correspondence between $\log$ responses, which in turn are related to rock and brine properties and the hydrotherial mineralogy. The most importapt controls on the log responses are changes in clay mineralogy and bulk dehsity of the shales fith thogressive hydrothermal metamorphism. The

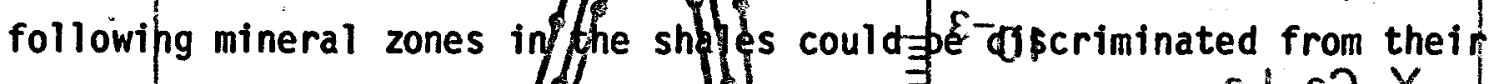

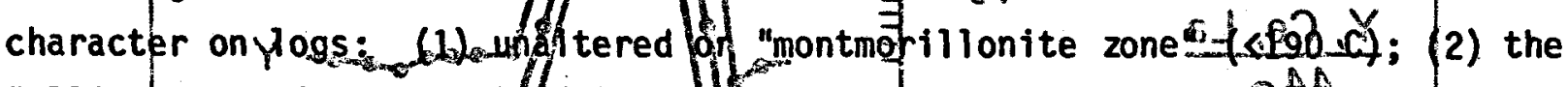
"illite zone" (190-250 c) f (3) the oflorite) zone" (250-300 CPA and (4) the described above for the fandstones pf Elmore No. OI (Table 4-9 and section 4.5.3). When the sames authigenic m|neral ocfurs in both sandstones and shales, it invariably appears at shatiower depth and lower temperature in the sandstopes. Muramoto's (1982) mineral_zones wererchosen on the basis of quantitative $X$-ray diffraction analyses of the shales. glerle

Changes in the share mineralogy have greater effects on resistivity and gamma-gamma denstev than do simi ar hanges in the sandstoresnol In Muramoto's study the ilute dhtorite and chaph zones-correspond to parts of the calcite-chlorite zone 30 sandstores on WicDowell and Elders (1980). There were insufficientiogs avaflable from the bigtistecand garnet izones to yield data for interpretatlon 1 .

Taple 4-10;shavs the forrelgtion between the minerablagnes in the shales with those inth sandstones togethe whth the ir effect5n93awinetine logs.

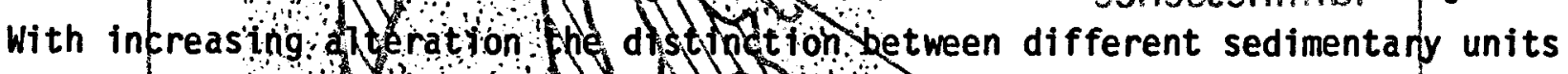

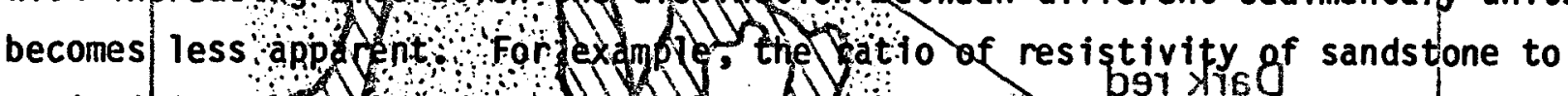

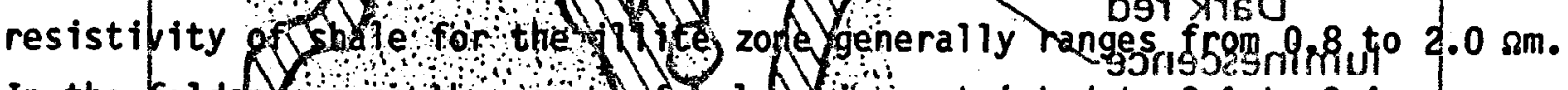
In the feldspon zone the nange po valus is restricted to 0.1 to $0.4 \Omega \mathrm{m}$.

The most useful log responses arehthe ratios of resistivity of shales to sandstopes, and resistivity-density or N-fesistivity crossplots (where $N=$ neutronlpocosity/density). An-example, shown in figure-4-20,-iltustrates the progressive increase in density with temperature and how induration has a much

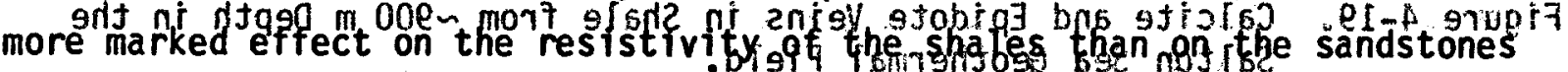

(Muramoto, 1982). Comparison of petrophysical data and log properties showed

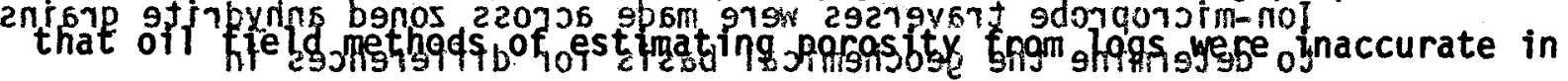

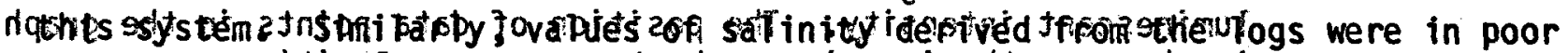

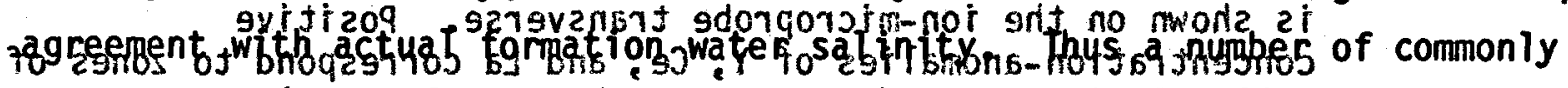

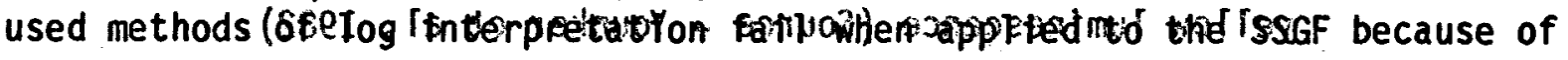
the association of high temperatures, high salinity, and high degree of rock alteration. 


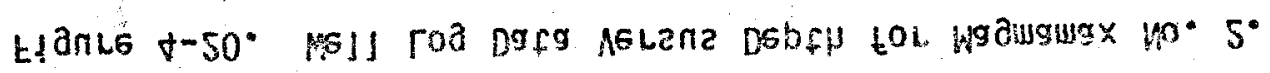

Table 4-10. Characteristic Log Response and Hydrothermal Mineralogy Within the Four Mineral Zones.

- - -

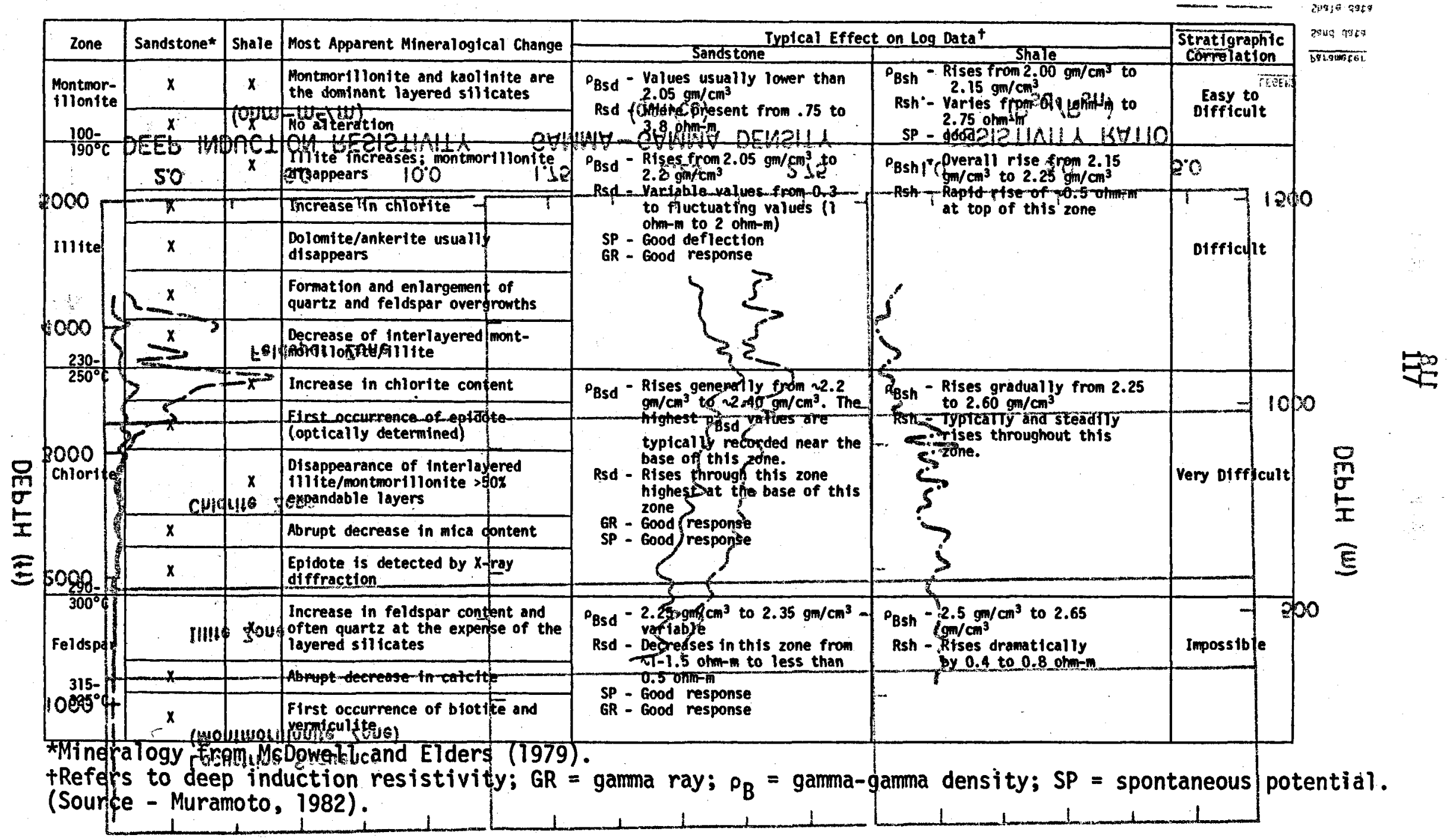




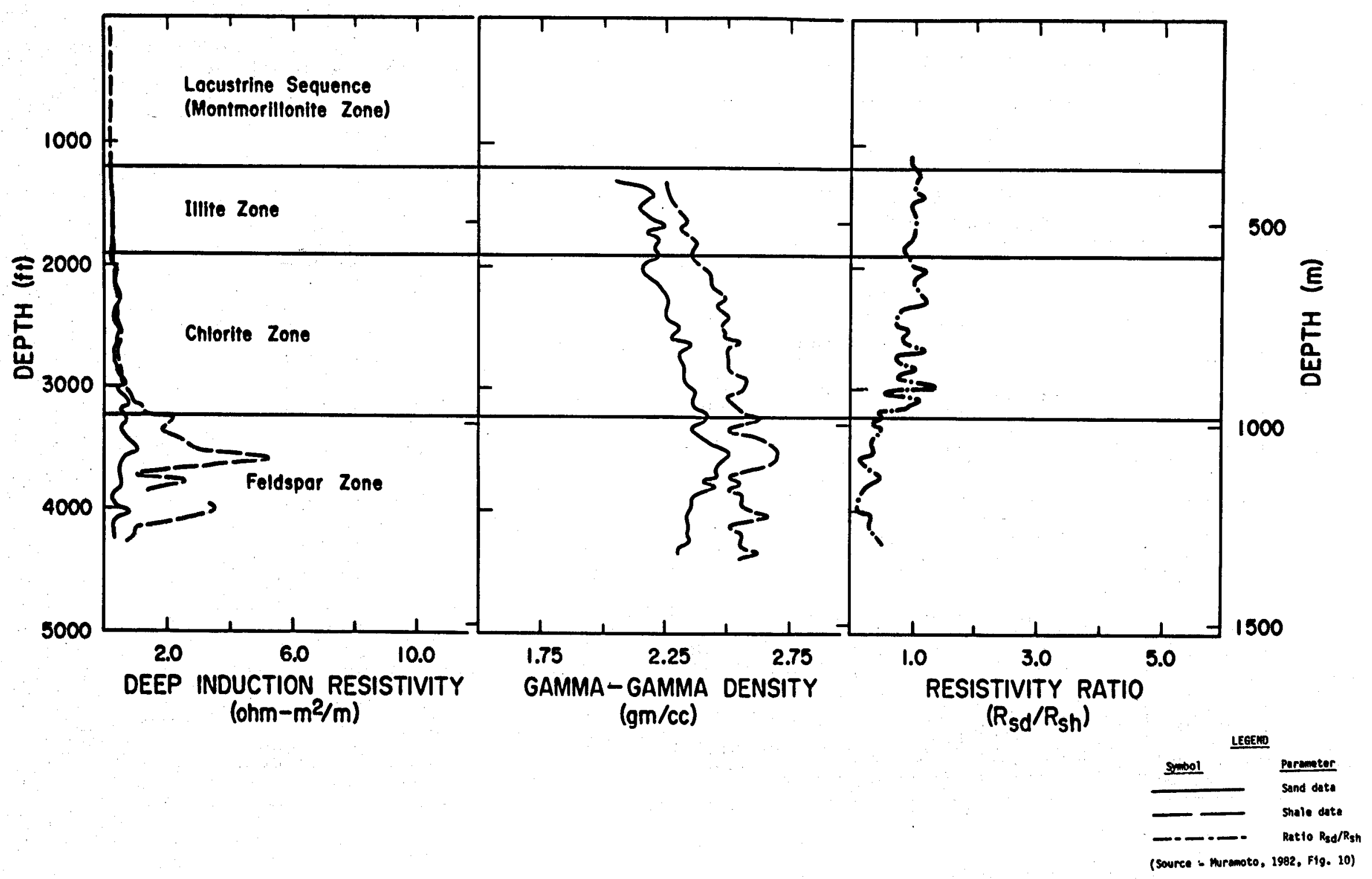

Figure 4-20. Well Log Data Versus Depth for Magmamax No. 2. 


\section{THE ON-GOING STUDY OF THE SSGF}

\subsection{INTRODUCTION}

Because some of the rock types, fluid compositions, and temperatures in this system overlap environments expected to be found in the near field of proposed radioactive waste repositories in salt, an extensive program of investigation of the migration and retardation of naturally occurring radionuclides in the Salton Sea Geothermal Field (SSGF) is now underway at the University of Californa, Riverside (UCR).

The concentration of uranium in brine from the SSGF is approximately 10 ppb. New brine samples are necessary in order to confirm these data and determine concentrations in the brine of other trace elements of interest to this project. Preliminary analyses of typical rock cores from this and other related geothermal systems in the Salton Trough indicate that these rocks contain the following concentrations of elements of interest: $U, 1.3-5.3 \mathrm{ppm}$; Th, 2.5-24.4 ppm; Sr, 181-534 ppm; and Cs, 0.5-7.5 ppm. Radiographic determinations indicate that mappable uranium is found almost exclusively associated with very fine-grained (0.1-0.005 $\mathrm{mm}$ ) matrix minerals including clay minerals, illite, chlorite, and epidote. More rarely, distinct track clusters were tied to crystals of feldspar or zircon. These uranium data are consistent with the observation that uranium contents of shale samples are in the range 4-5 ppm whereas that of the sandstones is only 1-2 ppm, independent of temperature over a range of 100 to $350 \mathrm{C}$.

The methods of analysis being employed include optical and electron microscopy, $X$-ray diffraction, $X$-ray fluorescence, atomic absorption, induced neutron activation, light isotope mass spectrometry, alpha counting, heavy isotope mass spectrometry, electron microprobe analysis, and radiography. The emphas is is on determining the locations, concentrations and migration paths of radionuclides and their reaction products.

\subsection{PROBLEMS OF ACCESS TO SAMPLES}

The limiting factor in performing this study is the avallability of subsurface data and appropriate well-documented samples of subsurface rocks and brines. This requires access to boreholes for sampling. Rock samples in 
the form of drill cores and cuttings can only be obtained during drilling; similarly, wireline logs must be run before wells are cased. Once obtained, these samples and data can be analyzed and interpreted at any subsequent. time. In contrast, water and gas samples can, in principle, be obtained at any time

the well is flowed after completion put must be analyzed immediately because

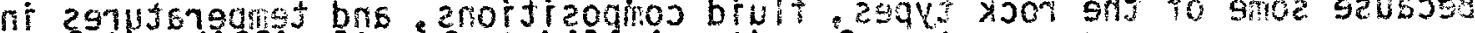
of the difficulty of stabilizing them for storage.

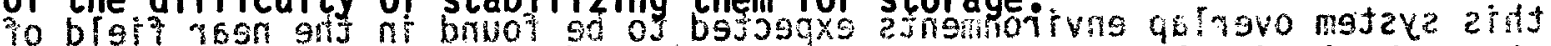
Prior to 1975 the Geothermal Resources Program at UCR obtained cuttings and limited amounts of core, together with well logs, for some 12 wells in the field. At that time problems of brine handling seemed to make the development

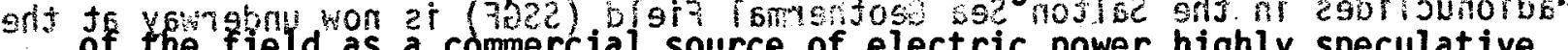
of the field as a commercial source of electric power highly speculative Consequently the operators of the wells released certain data and samples on

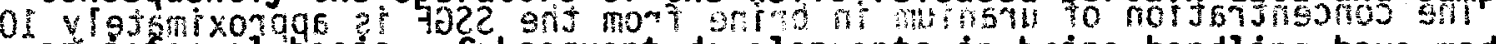
an informal basis. Subsequent developments in brine handling have made the

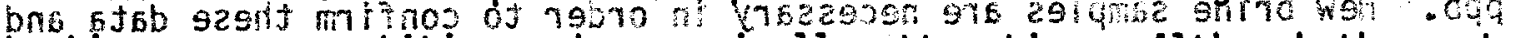
situation more competitive and economically attractive. Although the number of weils drilled has doubled, information from the newer wells is being held

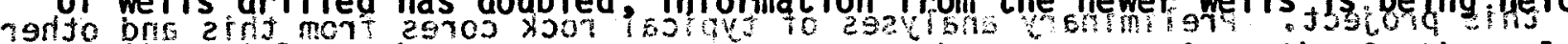
confidential by the two major operators at the present time the Gegthermal Division of Union Oil Company and Magma Power Company . However onepublic Geotherma 1 , Inc has released to us cuttings and water analyses from its wells

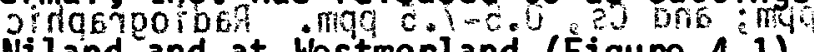

near Niland and at Westmorland (Figure 4-1). On-going work will be augmented with new brine and rock samples as as drilling in the SSGF proceeds the most ambitious plans for drilling being discussed at present are those of Republic Geothermal inc. "wich call for 976 drilling the Fee $\mathrm{No}$. 7 well to $3.7 \mathrm{~km}$ in the northeast part of the field

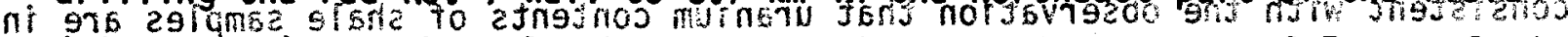
(Figure 4-1) It has al so been proposed to use Department af Energy funds to deepen this well to $5.5 \mathrm{~km}$ for scient ific purposes (Figure 4.4) to penetrate the roots of this geothermal system Samples from this project would then become available for this analog study.

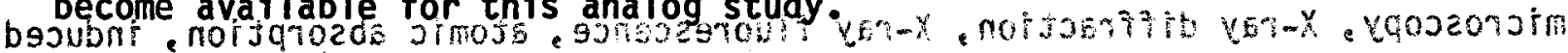

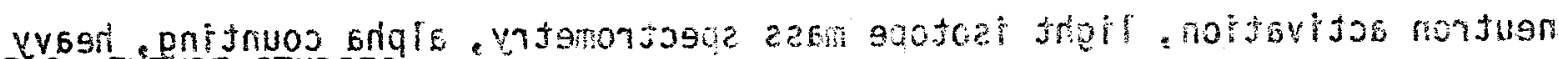
5.3 FUTTURE STUDIES

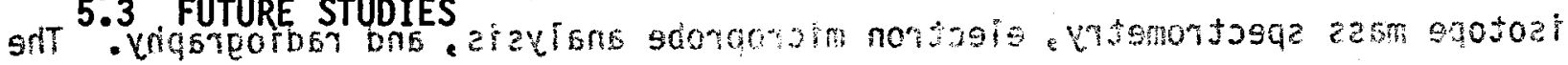

2ntsq not t67etm bns enoitst When our laboratory mineralogical, petrological and geochemical studjes are completed, the next stage will be to apply the data and concepts derived to problems of nuclear waste isolation. Qurginfarmatioß on the migsation and retardation of naturally-occurring radioactive and radiogenic elements in hot

brines moying through clay-rich rocks will be used for yalidatjon of geochemical models and computer codes. These model so wil haye applicatjons to

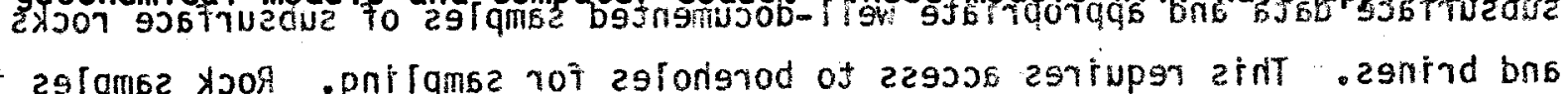


design of waste packages and backfill materials, and to assessments of the expected performance of engineering barrier systems and host rocks under conditions anticipated to occur in the near field of nuclear waste repositories in salt. 


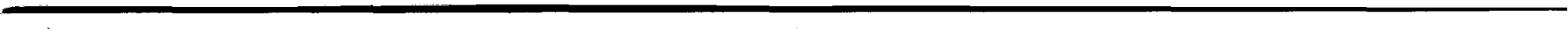

$\mathcal{U}$

$\mathcal{U}$ 


\section{REFERENCE LIST}

Aust in, A. L., A. W. Lundberg, L. B. Owen, and G. E. Tardiff, 1977. The LLL Geothermal Energy Program Status Report, January 1976-January 1977, UCRL 50046-76, Lawrence Livermore National Laboratory, Livermore, CA.

Babcock, E. A., 1971. "Detection of Active Faulting Using Oblique Infrared Aerial Photography in the Imperial Valley of California", Geological Society of America Bulletin, Vol. 82, pp. 3189-3196.

Batiza, R., 1978. "Geology and Petrology and Geochemistry of Is la Tortuga", Geological Society of America Bulletin, Vol. 89, pp. 1309-1324.

Batzle, M. L., and G. Simmons, 1976. "Microfractures in Rocks from Two Geothermal Areas", Earth and Planetary Science Letters, Vol. 30, pp. 71-93.

Berry, F. A. F., 1966. "Proposed Origin of Subsurface Thermal Brines, Imperial Valley, California", American Association of Petroleum Geologists Bulletin, Vol. 50, pp. 644-645.

Biehler, S., 1964. Geophysical Study of the Salton Trough of Southern California, Ph.D. Thesis, California Institute of Technology, Pasadena, CA, $139 \mathrm{p}$.

Biehler, S., 1971. "Gravity Studies in the Imperial Valley", Cooperative Geological-Geophysical-Geochemical Investigations of Geothermal Resources in the Imperial Valley Area of Calffornia, Final Report, Contract Number 14-06-300-2194, U.S. Bureau of Reclamation, pp. 29-42.

Biehler, S., R. L. Kovach, and C. R. Allen, 1964. "Geophysical Framework of Northern End of Gulf of California Structural Province", American Association of Petroleum Geologists, Memo No. 3, pp. 126-143.

Bird, D. K., 1975. Geology and Geochemistry of the Dunes Hydrothermal System, Imperial Valley of California, M.S. Thes is, UCR/IGPP-75/2, Institute of Geophysics and Planetary Physics, University of California, Riverside, CA, $134 \mathrm{p}$. 
Bird, D. K., and W. A. Elders, 1975. "Hydrothermal Alteration and Mass Transfer in the Discharge Portion of the Dunes Geothermal System, Imperial Valley of California, U.S.A.", Proceedings of the Second United Nations Geothermal Symposium (May 1975, San Francisco, CA), Vol. 1, pp. 285-295.

Bird, D. K., and D. L. Norton, 1981. "Theoretical Prediction of Phase Relations Among Aqueous Solutions and Minerals: Salton Sea Geothermal System", Geochimica et Cosmochimica Acta, Vol. 45, No. 9, pp. 1479-1493.

Browne, P. R. L., 1977. Occurrence and Hydrothermal Alteration of Diabase, Heber Geothermal Field, Imperial Valley, California, UCR/IGPP-77/9, Institute of Geophysics and Planetary Physics, University of California, Riverside, Riverside, CA.

Browne, P. R. L., and Elders, W. A., 1976. "Hydrothermal Alteration of Diabase, Heber Geothermal Field, Imperial Valley, California", Geological Society of America, Abstracts with Programs, Vol. 8, No. 6, p. 793.

California Department of Water Resources, 1970, Geothermal Wastes and Water Resources of the Salton Sea, Bulletin No. 143-7, $123 \mathrm{p}$.

Carey, S. W., 1958. "The Tectonic Approach to Continental Drift", Continental Drift, Proceedings of Geology Department Synposium Number 2, University of Tasmania, Hobart, Australia, pp. 177-355.

Carter, L. J., 1983. "The Radwaste Paradox", Science, Vol. 219, No. 7, pp. 33-36.

Chan, M. A., and J. D. Tewhey, 1977. Subsurface Structure of the Southern Portion of the Salton Sea Geothermal Field, UCRL-52354, Lawrence Livermore Laboratory, Livermore, CA.

Claiborne, H. C., L. D. Rickertsen, and R. F. Graham, 1980. Expected Environments in High-level Nuclear Waste and Spent Fuel Repositories in Salt, ORNL/TM-7201, Oak Ridge National Laboratory, Oak Ridge, TN. 
Clayton, R. N., L. J. P. Muffler, and D. E. White, 1968. "Oxygen Isotope Study of Calcite and Silicates of the River Ranch No. 1 Well, Salton Sea Geothermal Field, California", American Journal of Science, Vol. 266, pp. 968-979.

Coplen, T., 1976. Cooperative Geochemical Resource Assessment of the Mesa Geothermal System, Final Report, Contract No. 14-06-300-2479, U.S. Department of the Interior, Bureau of Reclamation, $105 \mathrm{p}$.

Coplen, T. B., P. Kolesar, R. E. Taylor, C. Kendall, and C. Mooser, 1975. Investigations of the Dunes Geothermal Anomaly, Imperial Valley, California: Part IV. Geochemical Studies of Water, Calcite, and Silicates, UCR/IGPP-75/20, Institute of Geophysics and Planetary Physics, University of California, Riverside, Riverside, CA, $43 \mathrm{p}$.

Cowan, G. A., 1976. "A Natural fission Reactor", Scientific American, Vol. 235, pp. 36-47.

Craig, H., 1961. "Isotopic Variations in Meteoric Waters", Science, Vol, 133, pp. 1702-1703.

Craig, H., 1963. "The Isotopic Geochemistry of Water and Carbon in Geothermal Areas", Proceedings of a Conference - Nuclear Geology in Geothermal Areas, (Spoleto, Italy), E. Tongiorgi, ed., pp. 17-53, Consiglio Nazionale delle Ricerche, Pisa, Italy.

Craig, H., 1966. "Isotopic Composition and Origin of the Red Sea and Salton Sea Geothermal Brines", Science, Vol. 154, pp. 1544-1548.

Craig, H., 1969. "Discussion: Source Fluids for the Salton Sea Geothermal System", American Journal of Science, Vol. 267, pp. 249-255.

Curry, J. R., D. G. Moore, and the Shipboard Scientists, 1979. "Leg 64 Seeks Evidence on Development of Basins in the Gulf of California", Geotimes, Vol. 24, No. 7, pp. 18-20. 
Degens, E. T., and D. A. Ross, eds., 1969. Hot Brines and Recent Heavy Metal Deposits in the Red Sea, Springer-Verlag, New York, NY, 600 p.

Dibblee, T. W., Jr., 1954. "Geology of the Imperial Valley Region, California", in "Geology of Southern California", R. H. Jahns, ed., California Division of Mines and Geology Bulletin, V. 170, pp. 21-28.

Doe, B. R., C. E. Hedge, and D. E. White, 1966. "Prel iminary Investigation of the Source of Lead and Strontium in Deep Geothermal Brines Underlying the Salton Sea Geothermal Area", Economic Geology, Vol. 61, pp. 462-483.

Elders, W. A., 1977. "Rock-Water Interaction and Temperature Distribution in the Salton Sea Geothermal Field, Imperial Valley, California, U.S.A.", Geological Society of America, Abstracts with Programs, Vol, 9, p. 965.

Elders, W. A., 1979, "The Geological Background of the Geothermal Fields of the Salton Trough", Geology and Geothermics of the Salton Trough, W. A. Elders, ed., Campus Museum Contribution No. 5, University of California, Riverside, CA, pp. 1-19.

Elders, W. A., 1981. "Applications of Petrology and Geochemistry to the Study of Active Geothermal Systems in the Salton Trough of California and Baja California", Process Mineralogy, Extractive Metallurgy, Mineral Exploration, Energy Resources, D. M. Hausen and W. C. Park, eds., The Metallurgical Society of AIME, Warrendale, PA, Pp. 591-606.

Elders, W. A., 1982. "Determination of Fracture History in Geothermal Reservoirs Through Study of Minerals", Fractures in Geothermal Reservoirs, Special Report 12, Geothermal Resources Council.

Elders, W. A., and S. Biehler, 1975. "Gulf of California Rift System and its Implication for the Tectonics of Western North America", Geology, Vol. 3, No. 2, pp. 85-87. 
Elders, W. A., and D. K. Bird, 1974. "Investigations of the Dunes Anomaly, Imperial valley, California: Part 2. Active Formation of Silicified Caprocks in Arenaceous Sands in a Low-Temperature Geothermal Environment in the Salton Trough of California, U.S.A.", Proceedings of the Symposium on Water-rock Reaction (Prague, Czechoslovakia), pp. 150-157.

Elders, W. A., R. Rex, T. Meidav, P. T. Robinson, and S. Biehler, 1972. "Crustal Spreading in Southern California", Science, Vol. 178, pp. 15-24.

Elders, W. A., J. R. Hoagland, E. R. Olson, S. D. McDowell, and P. Collier, 1978. A Comprehensive Study of Samples from Geothermal Reservoirs:

Petrology and Light Stable Isotope Geochemistry of Twenty-three Wells in the Cerro Prieto Geothermal Field, Baja California, Mexico, UCR/IGPP-78/26, University of California, Riverside, CA.

Elders, W. A., A. E. Williams, and J. R. Hoagland, 1981. "An Integrated Model for the Natural Flow Regime in the Cerro Prieto Hydrothermal System, B.C., Mexico, Based Upon Petrological and Isotope Geochemical Criteria", Proceedings of the Third Symposium on the Cerro Prieto Geothermal Field, (March 24-26, San Francisco, CA), LBL-11967, Lawrence Berkeley Laboratory, Berkeley, CA.

Elders, W. A., D. K. Bird, A. E. Williams, P. Schiffman, and B. Cox, 1982. "A Model for the Heat Source of the Cerro Prieto Magma-Hydrothermal System, Baja California, Mexico", Proceedings of the Fourth Symposium on the Cerro Prieto Geothermal Field, Vol. 1, pp. 265-284, (August 10-12, Guadalajara, Mexico).

Elders, W. A., A. E. Williams, D. K. Bird, and P. Schiffman, 1983. "Hydrothermal Flow Regime and Magmatic Heat Source of the Cerro Prieto Geothermal System, Baja California, Mexico", Geothermics, Vol. 13.

Ellis, A. J., and W. A. J. Mahon, 1977. Chemistry and Geothermal Systems, Academic Press, New York, NY, 392 p. 
Freckman, J. T., 1978. Fluid Inclusion and Oxygen Isotope Geothermometry of Rock Samples from Sinclair \#4 and Elmore \#1 Boreholes, Salton Sea Geothermal Field, Imperial Valley, California, U.S.A., M.S. Thesis, UCR/IGPP-78/5, Institute of Geophysics and Planetary Physics, University of California, Riverside, $C A, 66 \mathrm{p}$.

Frith, R. B., 1978. A Seismic Refraction Investigation of the Salton Sea Geothermal Area, Imperial Valley, California, M.S. Thesis, UCR/IGPP-78/19, Institute of Geophysics and Planetary Physics, University of California, Riverside, Riverside, CA, 94 p.

Fuis, G. S., W. D. Mooney, J. H. Healey, G. A. McMechan, and W. J. Lutter, 1982. "Crustal Structure of the Imperial Valley", The Imperial Valley, California Earthquake of October 15, 1979, Professional Paper 1254, U.S. Geological Survey, pp. 25-49.

Gastil, G., D. Krummenacher, and J. Minch, 1979. "The Record of Cenozoic Volcanism Around the Gulf of California", Geological Society of America Bulletin, Part 1, Vol. 88, No. 9, pp. 839-857.

Gilpin, B., and T.-C. Lee, 1978. "A Microearthquake Study in the Salton Sea Geothermal Area, California", Seismological Society of America Bulletin, Vol. 68 , pp. $441-450$.

Goldstein, N. E., M. J. Wilt, and D. J. Corrigan, 1983. "Analysis of the Nuevo Leon Magnetic Anomaly and its Possible Relation to the Cerro Prieto Magmatic Hydrothermal System", Geothermics, Vol. 13.

Gonzales, S., 1981. "Host Rocks for Radioactive-Waste Disposal", American Scientist, Vol. 70, pp. 191-200.

Griscom, A., and L. J. P. Muffler, 1971. Aeromagnetic Map and Interpretation of the Salton Sea Geothermal Area, California, Geophysical Investigations Map GP 754, U.S. Geological Survey. 
Hamilton, R. M., 1972. Aftershocks of the Borrego Mounta in Earthquake from April 12 to June 12, 1968, Professional Paper 787, U.S. Geological Survey, pp. $31-54$.

Harrar, J. E., C. H. Otto, S. B. Deutscher, R. W. Ryan, and G. E. Tardiff, 1979. Studies of Brine Chemistry, Precipitation of Solids and Scale Formation at the Salton Sea Field, UCRL-52640, Lawrence Livermore National Laboratory, Livermore, $C A$.

Helgeson, H. C., 1967. "Solution Chemistry and Metamorphism", Researches in Geochemistry, P. H. Abelson, ed., Vol. 2, pp. 362-404.

Helgeson, H. C., 1968. "Geologic and The rmodynamic Characteristics of the Salton Sea Geothermal System", American Journal of Science, Vol. 266, No. 3, pp. 129-166.

Hoagland, J. R., and W. A. Elders, 1978. "Hydrothermal Mineralogy and Isotopic Geochemistry in the Cerro Prieto Geothermal Field, Mexico I. Hydrothermal Mineral Zonation", Geothermal Resources Council Transactions, Vol. 2, pp. 283-286.

Humphreys, G., 1978. Telluric Sounding and Mapping in the Vicinity of the Salton Sea Geothermal Area, Imperial Valley, California, M.S. Thesis, UCR/IGPP-78/17, Institute of Geophysics and Planetary Physics, University of California, Riverside, Riverside, CA, $159 \mathrm{p}$.

Ingle, J., 1982. Microfaunal Evidence of Age and Depositional Environments of the Cerro Prieto Section (Plio-Pleistocene), Baja California, Mexico, LBL-13897, Lawrence Berkeley Laboratory, Berkeley, CA.

(IRGNWM) Interagency Review Group on Nuclear haste Management, 1979. Report to the President by the Interagency Review Group on Nuclear Waste Management, TID-29442, U.S. Government Report. 
Jenks, G. H., 1979. Effects of Temperature, Temperature Gradients, Stress, and Irradiations of Brine Inclusions in a Salt Repository, ORNL-5526, 0ak Ridge National Laboratory, Oak Ridge, TN.

Johnson, C. E., and D. P. Hill, 1982. Seismicity in the Imperial Valley, Professional Paper 1254, U.S. Geological Survey, pp. 15-24.

Johnson, K. S., and S. Gonzales, 1978. Salt Deposits in the United States and Regional Geologic Characteristics Important for Storage of Radioactive Waste, Y/OWI/SUB-7414/1, Office of Nuclear Waste Isolation, Oak Ridge, TN.

Kay, R., N. J. Hubbard, and P. W. Gast, 1970. "Chemical Characteristics and Origin of Oceanic Ridge Volcanic Rocks", Journal of Geophysical Research, Vol. 85, pp. 1585-1613.

Keith, T. E. C., L. J. P. Muffler, and M. Cremer, 1968, "Hydrothermal Epidote Formed in the Salton Sea Geothermal System, California", American Mineralogist, Vol. 53, pp. 1635-1644.

Kelley, V. C., and J. L. Soske, 1936. "Origin of the Salton Volcanic Domes, Salton Sea, California", Journal of Geology, Vol . 44, pp. 496-509.

Kenda11, C., 1976. Petrology and Stable Isotope Geochemistry of Three Wells in the Buttes Area of the Salton Sea Geothermal Field, Imperial Valley, California, U.S.A., M.S. Thesis, UCR/IGPP-76/17, Institute of Geophysics and Planetary Physics, University of California, Riverside, Riverside, CA, 227 p.

Keskinen, M., and J. Sternfeld, 1982. "Hydrothermal Alteration and Tectonic Setting of Intrusive Rocks from East Brawley, Imperial Valley: An Application of Petrology to Geothermal Reservoir Analysis", Proceedings of the Eighth Workshop on Geothermal Reservoir Engineering (December 14-16, Stanford University, Stanford, (A), pp. 39-44.

$\mathrm{Kl}$ ingsberg, C., and J. Duguid, 1980. Status and Technology for Isolating High-level Radioactive Wastes in Geologic Repositories, DOE/TIC 11207, U.S. Department of Energy. 
$\mathrm{Kl}$ ingsberg, C., and J. Duguid, 1982. "Isolating Radioactive-Wastes", American Scientist, Vol. $70, \mathrm{pp}$. 182-189.

Lande, D., 1979. "A History of Drilling in the Imperial Valley", Geology and Geothermics of the Salton Trough, W. A. Elders, ed., Campus Museum Contribution No. 5, University of California, Riverside, CA, pp. 45-46.

Lebedev, L. M., 1973. "Minerals of Contemporary Hydrotherms of Cheleken", Geochemistry International, Vol. 9, pp. 485-504.

Lee, T.-C., and L. H. Cohen, 1979. "Onshore and Offshore Measurements of Temperature Gradients in the Salton Sea Geothermal Area, California", Geophysics, Vol. 44, No. 2, pp. 206-215.

Lewis, B. T. R., 1978. "Evolution of Ocean Crust Seismic Velocities", Annual Review of Earth and Planetary Sciences, Vol. 6, pp. 377-404.

Loeltz, 0. J., B. Irelan, J. H. Robison, and F. H. Olmsted, 1975. Geohydrologic Reconnaissance of the Imperial Valley, California, Professional Paper 486-K, U.S. Geological Survey, 54 p.

Lomnitz, C., F. Mooser, C. Allen, J. N. Brune, and W. Thatcher, 1970. "Sefsmicity of the Gulf of California Region, Mexico - Preliminary Results", Geofisica Internacional, Vol. 10, p. 37.

Lucchitta, I., 1972. "Early History of the Colorado River in the Basin and Range Province", Geological Society of America Bulletin, Vol. 83, pp. 1933-1948.

Maimoni, A., 1982. "Minerals Recovery from Salton Sea Geothermal Brines: A Literature Review and Proposed Cementation Process", Geothermics, Vol. 11, pp. 239-258. 
McDowel1, S. D., and W. A. Elders, 1979. "Geothermal Metamorphism of Sandstone in the Salton Sea Geothermal System", Geology and Geothermics of the Salton Trough, W. A. Elders, ed., Campus Museum Contribution No. 5, University of California, Riverside, CA, pp. 70-76.

McDowell, S. D., and W. A. Elders, 1980. "Authigenic Layer Silicate Minerals in Borehole Elmore 1, Salton Sea Geothermal Field, California, U.S.A.", Contributions to Mineralogy and Petrology, Vol. 74, pp. 293-310.

McDowe11, S. D., and M. McCurry, 1978. Mineralogical Variations in Borehole Elmore \#1, Salton Sea Geothermal Area: Prel iminary Report, UCR/IGPP-78/11, Institute of Geophysics and Planetary Physics, University of California, Riverside, Riverside, CA, $50 \mathrm{p}$.

McKibben, M. A., 1979. Ore Minerals in the Salton Sea Geothermal System, Imperial Valley, California, U.S.A., M.S. Thesis, UCR/IGPP-79/17, Institute of Geophysics and Planetary Physics, University of California, Riverside, Riverside, $C A, 99 \mathrm{p}$.

Meidav, T., and R. Furgerson, 1972. "Resistivity Studies of the Imperial Valley Geothermal Area, California", Geothermics, Vol. 1, pp. 47-62.

Meidav, T., and J. H. Howard, 1979. "An Update of Tectonics and Geothermal Resource Magnitude of the Salton Sea Geothermal Resource", Geothermal Resources Council Transactions, Vol. 3, pp. 445-448.

Meidav, T., R. West, A. Katzenstein, and Y. Rostein, 1976. An Electrical Resistivity Survey of the Salton Sea Geothermal Field, Imperial Valley, California, UCRL-13690, Lawrence Livermore National Laboratory, Livermore, CA.

Moody, J. B., 1982. Radionuclide Migration/Retardation Research and Development - Technology Status Report, ONWI-321, Office of Nuclear Waste Isolation, Battelle Memorial Institute, Columbus, $\mathrm{OH}$. 
Moore, D. G., 1973. "Plate Edge Deformation and Crustal Growth, Gulf of California Structural Province", Geological Society of America Bulletin, Vol. 84, p. 1883.

Morse, J. G., and L. D. Thorson, 1978. "Reservoir Engineering Study of a Portion of the Salton Sea Geothermal Field", Geothermal Resources Council Transactions, Vol. 2, pp. 471-474.

Muffler, L. J. P., 1979. Assessment of the Geothermal Resources of the United States - 1978, Circular 790, U.S. Geological Survey.

Muffler, L. J. P., and B. R. Doe, 1968. "Composition and Mean Age of Detritus of the Colorado River Delta in the Salton Trough, Southeastern California", Journal of Sedimentary Petrology, Vol. 38, No. 2, pp. 384-399.

Muffler, L. J. P., and D. E. White, 1968. "Origin of $\mathrm{CO}_{2}$ in the Salton Sea Geothermal System, Southeastern California, U.S.A.", Proceedings of the 23rd International Geological Congress (Prague, Czechoslovakia), Vol. 97 (Symposium 2), pp. 185-194.

Muffler, L. J. P., and D. E. White, 1969. "Active Metamorphism of Upper Cenozoic Sediments in the Salton Sea Geothermal Field and the Salton Trough, Southeastern California", Geological Society of America Bulletin, Vo1. 80, pp. 157-182.

Muramoto, F. S., 1982. The Use of Well Logs to Determine the Effects of Hydrothermal Alteration and Other Reservoir Properties of the Salton Sea and Westmorland Geothermal Systems in the Imperial Valley, California, U.S.A., M.S. Thesis, UCR/IGPP-82/14, Institute of Geophysics and Planetary Physics, University of California, Riverside, Riverside, $C A$.

Needham, P. B., Jr., W. D. Riley, G. R. Conner, and A. P. Murphy, 1980. "Chemical Analyses of Brines from Four Imperial Valley, California, Geothermal Wells", Society of Petroleum Engineering Journal, Vol . 20, No. 2, pp. 105-112. 
01msted, F. H., 0. J. Loeltz, and B. Ireland, 1973. Geohydrology of the Yuma Area, Arizona and California, Professional Paper 486-H, U.S. Geological Survey, $227 \mathrm{p}$.

0lson, E. R., 1976. "Oxygen Isotope Studies of the Salton Sea Geothermal Field: New Insights", Stable Isotopes in the Earth Sciences, B. W. Robinson, comp. and ed., DSIR Bulletin 220, New Zealand Department of Scientific and Industrial Research, pp. 121-126.

0l son, E. R., and J. S. Matlick, III, 1978. A Flow-through Model for the Westmorland Geothermal System, Imperial Valley, Cal ifornia, UCR/IGPP-78/7, Institute of Geophysics and Planetary Physics, University of California, Riverside, Riverside, $\mathrm{CA}, 37 \mathrm{p}$.

Palmer, T. D., 1975. Characteristics of Geothermal Wells Located in the Salton Sea Geothermal Field, Imperial County, California, UCRL-51976, Lawrence Livermore National Laboratory, Livermore, CA.

Pourade, R. F., 1971. Anza Conquers the Desert, Copley Press, Inc., San Diego, $216 \mathrm{p}$.

Randal1, W., 1974. An Analysis of the Subsurface Structure and Stratigraphy of the Salton Sea Geothermal Anomaly, Imperial Valley, California, Ph.D. Dissertation, University of California, Riverside, CA.

Rex, R. W., ed., 1972. "Origin of the Salt of the Imperial Valley and Surrounding Watershed Area", Cooperative Investigation of Geothermal Resources in the Imperial Valley Area and Their Potential Value for Desalting of Water and Other Purposes, Final Report, Contract No. 14-06-300-2194, U.S. Department of the Interior, Bureau of Reclamation, $267 \mathrm{p}$.

Rex, R. W., 1983. "The Origin of the Brines of the Imperial Valley, California", Geothermal Resources Council Transactions, Annual Meeting (October 1983). 
Riney, T. D., J. W. Pritchett, and S. K. Garg, 1978. "Salton Sea Geothermal Reservoir Simulations", Geothermal Resources Council Transactions, Vol. 2, pp. 571-574.

Robinson, P. T., W. A. Elders, and L. J. P. Muffler, 1976. "Quaternary Volcanism in the Salton Sea Geothermal Field, Imperial Valley", Geological Society of America Bulletin, Vol . 87, pp. 347-360.

Roedder, E., and R. L. Bassett, 1981. "Problems in Determination of the Water Content of Rock-Salt Samples and its Significance in Nuclear-Waste Storage Siting", Geology, Vol. 9, pp. 525-530.

Savino, J. M., W. L. Rodi, R. C. Goff, T. H. Jordan, J. H. Alexander, and D. G. Lambert, 1977. Inversion of Combined Geophysical Data for Determination of Structure Beneath the Imperial Valley, SAN-1313-1, U.S. Department of Energy.

Schnapp, M., and G. Fuis, 1977. Preliminary Catalog of Earthquakes in the Northern Imperial Valley, October 1, 1976 to December 31, 1976, Open File Report 77-431, U.S. Geological Survey, 19 p.

Schroeder, R. C., 1976. Reservoir Engineering Report for the Magma-SDG\&E Geothermal Experimental Site Near the Salton Sea, California, UCRL-52094, Lawrence Livermore National Laboratory, Livermore, CA.

Sharp, R. V., 1982. Tectonic Setting of the Imperial Valley Region, Professional Paper 1254, U.S. Geological Survey, pp. 5-14.

Skinner, B. J., D. E. White, H. J. Rose, and R. E. Mays, 1967. "Sulfides Associated with the Salton Sea Geothermal Brine", Economic Geology, Vol. 62, No. $3, \mathrm{pp}$. 316-330.

Sykes, G., 1937. The Colorado River Delta, Publication No. 460, Carnegie Institution of Washington, Washington, $D C$. 
Tammemagi, H. Y., G. E. Grisak, and D. K. Parrish, 1983. A Case History of the Marysville Geothermal Anomaly from a Nuclear-Waste Disposal Perspective, INF0-0092, prepared for the Atomic Energy Control Board, Ottawa, Canada.

Tewhey, J. D., 1977. Geologic Characteristics of a Portion of the Salton Sea Geothermal Field, UCRL-52267, Lawrence Livermore National Laboratory, Livermore, CA, $51 \mathrm{p}$.

Thatcher, W., J. N. Brune, and D. N. Clay, 1971. "Seismic Evidence on the Crustal Structure of the Imperial Valley Region", Geological Society of America, Abstracts with Programs, Vol. 3, No. 2, p. 208.

Towse, D., 1975, An Estimate of the Geothermal Energy Resource in the Salton Trough, California, UCRL-51851, Lawrence Livermore National Laboratory, Livermore, CA.

Towse, D. F., and T. D. Palmer, 1975. Summary of Geology at the ERDA-Magma-SDG\&E Geothermal Test Site. UCID-17008, Lawrence Livermore National Laboratory, Livermore, CA.

United States Environmental Protection Agency, 1981. "Environmental Standards for the Management and Disposal of Spent Nuclear Fuel, High-level, and Transuranic Radioactive Wastes, (40 CFR 191)", Federal Register, Vol. 47, No. 250, pp. 58196-58206.

United States Geological Survey, 1982. The Imperial Valley, California, Earthquake of October 15, 1979, Professional Paper 1254, U.S. Geological Survey, $451 \mathrm{p}$.

United States Nuclear Regulatory Commission, 1983. "Disposal of High-level Radioactive Wastes in Geologic Repositories: Performance objectives and Technical Criteria (10 CFR 60)" Federal Register, Vol. 48, No. 120, pp. 28194-28229. 
Van de Kamp, P. C., 1973. "Holocene Continental Sedimentation in the Salton Basin, California: A Reconnaissance", Geological Society of America Bulletin, Vol. 84, pp. 827-848.

Wagoner, J. L., 1977. Stratigraphy and Sedimentation of the Pleistocene Brawley and Borrego Formations in the San Felipe Hills area, Imperial Valley, California, U.S.A., M.S. Thesis, UCR/IGPP-77/24, Institute of Geophysics and Planetary Physics, University of California, Riverside, Riverside, CA.

Wegener, A., 1924. The Origin of Continents and Oceans, 3rd edn, Dutton, New York, NY, pp. 184-185.

White, A. F., 1980. Comparative Assessment of Five Potential Sites for Hydrothermal Magma Systems: Geochemistry, LBL-11410, Lawrence Berkeley Laboratory, Berkeley, CA.

White, D. E., 1968. "Environments of Generation of Some Base Metal Ore Deposits", Economic Geology, Vol . 63, No. 4, pp. 301-335.

White, D. E., 1970. "Geochemistry Applied to the Discovery, Evaluation, and Exploitation of Geothermal Energy Resources", Proceedings of the United Nations Symposium on the Development and Utilization of Geothermal Resources (Pisa), Vol. 2, Part 1. Geothermics, Special Issue No. 2.

White, D. E., 1981. "Geothermal Systems and Hydrothermal Ore Deposits", Economic Geology, Seventy-fifth Anniversary Volume, B. J. Skinner, ed., pp. $392-423$.

White, D. E., E. T. Anderson, and D. K. Grubbs, 1963. "Geothermal Brine We11: Mile-deep Drill Hole May Tap Ore-bearing Magmatic Water and Rocks Undergoing Metamorphism", Science, Vol . 139, pp. 919-922.

Woodard, G. D., 1974. "Redefinition of Cenozoic Stratigraphic Column in Split Mountain Gorge, Imperial Valley, California", American Association of Petroleum Geologists, Vol. 58, pp. 521-539. 
Younker, L., and P. W. Kasameyer, 1978. A Revised Estimate of Recoverable Thermal Energy in the Salton Sea Geothermal Resource Area, UCRL-52450, Lawrence Livermore National Laboratory, Livermore, CA.

Younker, L. W., P. W. Kasameyer, and J. D. Tewhey, 1982. "Geological, Geophysical, and Thermal Characteristics of the Salton Sea Geothermal Field, California", Journal of Volcanology and Geothermal Resources, Vol . 12, pp. 221-258. 


\section{DISTRIBUTION LIST}

ACRES AMERICAN INC A. S. BURCESS ROBERT H. CURTIS R. STRUBLE

AEROSPACE CORP BARRETT R. FRITZ

ALABAMA DEPT OF ENERGY CAMERON MCDONALD

ALABAMA STATE GEOLOGICAL SURVEY THORNTON L. NEATHERY

ALLIED GENERAL NUCLEAR SERVICES P. F. HIGHBERGER

ALLIS-CHALMERS GARRICK J. SOLOVEY

AMARILLO PUBLIC LIBRARY

AMERICAN FRIENDS SERVICE COMMITIEE WILLIAM REYNOLDS

AMERICAN NUCLEAR ENERGY COUNCIL. EDWARD M. DAVIS

AMERICAN NUCLEAR INSURERS DOTTIE SHERMAN

AMERICAN PHILOSOPHICAL ASSOCIATION JOHN OCONNOR

ANALYSIS AND TECHNOLOGY INC T. MAZOUR

APPLED MECHANICS INC GRAHAM G. MUSTOE JOHN R. WILLIAMS

ARGONNE NATIONAL LABORATORY DAVID F. FENSTER WYMAN HARRISON J. HOWARD KITTEL MARTIN SEITZ MARTIN J. STEINDLER

ARINC RESEARCH CORP H. P. HIMPLER

ARIZONA PUBLIC SERVICE COMPANY HENRY W. RILEY, IR.

ARIZONA STATE UNIVERSITY PAUL KNAUTH

ARKANSAS GEOLOGICAL COMMISSION WILLIAM V. BUSH NORMAN F. WILIAMS

ARTHUR D. LITTE INC AVIVA BRECHER CHARLES R. HADLOCK

ATKINS RESEARCH \& DEVELOPMENT - UNITED KINGDOM T. W. BROYD

ATOMIC ENERGY CONSULTANTS DONALD G. ANDERSON

ATOMIC ENERGY CONTROL BOARD CANADA J. L. WALLACH

ATOMIC ENERGY COUNCIL - REPUBLIC OF CHINA

C. S. YEH

ATOMIC ENERGY OF CANADA LTD M. O. LUKE ANN QUINN

ATOMIC ENERGY RESEARCH ESTABLISHMENT

- UNITED KINGDOM JOHN RAE

ATOMIC INDUSTRIAL FORUM INC EMANUEL GORDON

AUSTRALIAN ATOMIC ENERGY COMMISSION

BABCOCK \& WILCOX INFORMATION SERVICES

BALL ASSOCIATES LID DOUGLAS BALL
BATHEUE COLUMBUS DIVISION

JOHN T. MCGINNIS

JEFFREY L. MEANS

STEPHEN NICOLOSI

THOMAS M. TRAINER

KENNETH R. YATES

BECHTEL CROUP INC

LESLIE J. JARDINE

R. C. LOVINGTON

N. A. NORMAN

GERALD L. PALAU

U. YOUNG PARK

RICHARD !. TOSETT

BECHTEL NATIONAL INC TOM S. BAER

BENDIX FIELD ENGINEERING CORP

CHARLES A. IONES

MICHAEL H. MOBLEY

JOHN C. PACER

BHABHA ATOMIC RESEARCH CENTER - INDIA V. SUKUMORAN

BIENVILLE PARISH LIBRARY

BLOXI PUBLIC LIBRARY

BLACK \& VEATCH

M. JOHN ROBINSON

BOEINC ENGINEERING AND CONSTRUCTION COMPANY

R. B. CAIRNS

BRENK SYSTEMPLANUNG - W. GERMANY H. D. BRENK

BRITISH NUCLEAR FUELS LTD

R. S. WILKS

EROOKHAVEN NATIONAL LABORATORY

M. S. DAVIS

SANDRA C. LANE

P. W. LEY

PETER SOO

HELEN TODOSOW (2)

BUNDESANSTALT FUR GEOWISSENSCHAFTEN

UND ROHSTOFFE - W. GERMANY

MICHAEL LANGER

HELMUT VENZLAFF

BUNDESMINISTERIUM FUR FORSCHUNG UND

TECHNOLOGIE - W. GERMANY

ROLF-PETER RANDL

BUREAU DE RECHERCHES GEOLOGIQUES ET

PIERRE F. PEAUDECERF

BURNS AND ROE INDUSTRIAL SERVICES CORP JOHN PIRRO

C. F.H. F.

BILL DUESING

CALIFORNIA DEPT OF CONSERVATION PERRY AMIMITO

CALFFORNIA DEPT OF HEALTH SERVICES BEVERLEE MYERS

CALFORNIA DIVISION OF MINES \& GEOLOCY ROBERT H. SYDNOR

CANYONLANDS NATIONAL PARK PETER L. PARRY

CAPITAL AREA GROUND WATER CONSERYATION COMMISSION A. N. TURCAN, JR.

CARNEGIE-MEUON UNIVERSTY INDIRA NAIR

CASTLE VALIEY ORCHARDS CARL ANDERSON

CAYUGA LAKE CONSERYATON ASSOCIATION INC

D. S. KIEFER
MINIERES - FRANCE
CENTER FOR ENVIRONMENTAL

INFORMATION INC

FREDERICK $W$. STOSS

CENTRE D ETUDE DE L ENERGIE NUCLEAIRE BELCIUM

RENE HEREMANS

CENTRE D INFORMATIQUE GEOLOGIQUE . FRANCE GHISLAIN DEMARSILY

CHEM-NUCLEAR SYSTEMS INC ROBIN L. DEAL

CITIZENS ASSOCIATION FOR SOUND ENERGY JUANITA ELLIS

CITIZNSS FOR A BETTER ENVIRONMENT IOANNA HOELSCHER

CITIZENS INSTITUTE FOR A POSTIVE ENERGY POLICY

LINDSAY AUDIN

CLEVELAND ELECTRIC HUMINATING CO PAUL G. KLANN

COLORADO GEOLOGICAL SURVEY JOHN W. ROLD

COLORADO SCHOOL OF MINES W. HUSTRULID DONALD LANGMUIR

CONNECTICUT SITING COUNCIL GLORIA DIBBLE POND

CONROY ENGINEERING PETER CONROY

CONSOIL ASSOCIATES DAVID A. LEE

CONVERSE WARD A. M. HALE

COPPE/UFRI - BRAZL LUIZ OLIVIERA

CORNEU UNIVERSITY JOHN BIRD ARTHUR L. BLOOM DUANE CHAPMAN FRED H. KULHAWY ROBERT POHL

CORTLAND COUNTY HEALTH DEPT j. V. FEUSS

D. R. E KARL I. ANANIA

DALTON, DALTON \& NEWPORT MARIA R. EIGERMAN

DAMES Q MOORE RON KEAR CHARLES R. LEWIS O. L. OZTUNOLI

DAPPOLONIA CONSULTINC ENCINEERS INC LISA K. DONOHUE ABBY FORREST AMINA HAMDY PETER C. KELSAL CARL E SCHUBERT

DAWCON MANAGEMENT CONSULTING SERVICE

DAVID A. WEBSTER

DEAF SMITH COUNTY LIBRARY

DELAWARE GEOLOGICAL SURVEY ROBERT R. JORDAN

DEUTSCHE GESELLCHAFT FUR

WIEDERAUFARBEITUNC VON HANKE WERTHMANN

DIXON ASSOCIATES I. DONALD DIXON

DUCHESNE LAND \& OIL JOHN E. DOOLEY 
DUKE UNIVERSITY

THOMAS DAVIS

DUNN GEOSCIENCE CORP WILLIAM E. CUTCLIFFE

DYNATECH R/D COMPANY STEPHEN E. SMITH

E. I. DU PONT NEMOURS \& CO D. H. TURNO

E. L. H. PUBLICATIONS - THE HELMINSKI \& WILKEN

E. R. JOHNSON ASSOCIATES INC E. R. JOHNSON G. L. JOHNSON

EAL CORP LEON LEVENTHAL

EARTH RESOURCE ASSOCIATES INC SERGE GONZALES

EARTH SCIENCE AND ENGINEERING INC LOU BLANCK

EAST COMPANY INC RAYMOND PEREZ

EAST TENNESSEE STATE UNIVERSITY ALBERT F. IGLAR MICHAEL R. SMITH

EBASCO SERVICES INC ZUBAIR SALEEM RAYMOND H. SHUM

ECOLOGY \& ENVIRONMENT INC MICHAEL BENNER

ECOLOGY CENTER OF LOUISIANA ROSS VINCENT

EDISON ELECTRIC INSTITUTE R. E. L. STANFORD

EDS NUCLEAR INC C. SUNDARARAJAN

EG \& G IDAHO INC GEORGE B. LEVIN ROGER A: MAYES M. D. MCCORMACK T. H. SMITH

ELECTRIC POWER RESEARCH INSTITUTE CHAIM BRAUN

ELSAM - DENMARK A. V. JOSHI ARNE PEDERSEN

ENERGY FUELS NUCLEAR INC DON M. PILLMORE

ENERGY INC

ENERGY RESEARCH GROUP INC MARC GOLDSMITH

ENGINEERS INTERNATIONAL INC FRANCIS S. KENDORSKI

ENVIRONMENTAL POLICY INSTTIUTE DAVID M. BERICK FRED MILLAR

ENVIRONMENTAL RESOURCES MANAGEMENT INC RONALD A. LANDON, P.E.

ENVIROSPHERE COMPANY ROGER G. ANDERSON K. E. LIND-HOWE

ERIE COUNTY ENVIRONMENTAL MANAGEMENT COUNCI JOAN P. SCHMIDT

ERTEC WESTERN INC JOSEPH G. GIBSON MATT WERNER KENNETH L. WILSON

EXXON NUCLEAR IDAHO COMPANY INC GARY WAYMIRE
FENIX \& SCISSON INC JOSE A. MACHADO CHARLENE U. SPARKMAN

FLORIDA DEPT OF-ENVIRONMENTAL REGULATION HAMILTON OVEN

FLORIDA INSTITUTE OF TECHNOLOCY JOSEPH A. ANGELO, JR.

FLORIDA POWER \& LUGHT COMPANY IAMES R. TOMONTO

FLORIDA STATE UNIVERSITY JOSEPH F. DONOGHUE

FLUOR ENGINEERS \& CONSTRUCTORS INC JOAN V. MCCURRY

FORD, BACON \& DAVIS INC ROBERT D. BAIRD DARRELL H. CARD ROBERT F. OVERMYER BURTON J. THAMER

FOSTER-MILLR ASSOCIATES INC NORBERT PAAS

FREESTONE COUNTY COURTHOUSE SAM BOURNIAS

FREE UNIVERSTIAET BERLIN HANSKARL BRUEHL

FRIENDS OF THE EARTH RENEE PARSONS

GABIE BETTS BURTON MEMORIAL UBRARY

GENERAL ATOMIC COMPANY ROBERT J. CAMPANA H. C. CARNEY

GENERAL COURT OF MASSACHUSETTS TIMOTHY I. BURKE

GENERAL ELECTRIC COMPANY BRUCE HUTCHINS

GEO/RESOURCE CONSULTANTS INC ALVIN K. JOE, JR.

GEOLOGICAL SURVEY OF CANADA JEFFREY HUME LIBRARY

GEOLOGICAL SURVEY OF DENMARK L. F. ANDERSEN

GEOLOGICAI SURVEY OF NORWAY SIGURD HUSEBY

GEORGETOWN CONSULTING GROUP SUSAN SHALAGAN

GEORGIA INSTITUTE OF TECHNOLOGY MELVIN W. CARTER GEOFFREY G. EICHHOLZ ALFRED SCHNEIDER CHARLES E. WEAVER

GEOTECHNICAL ENGINEERS INC RONALD C. HIRSCHFELD

GEOTHERMAI ENERGY INSTITUTE DONALD F. $X$. FINN

GEOTHERMAL WORLD COMPANY EDITORIAL AND ADVERTISING OFFICE GEOTRANS IAMES MERCER

CERMANTOWN FRIENDS SCHOOL HERB BASSOW

GESELLSCHAFT F. STRAHLEN U. UMWELTFORSCHUNG M.B.H. - W. GERMANY

WOLFGANG BODE H. MOSER

GESELLSCHAFT FUR STRAHLEN-UND UMWELTFORSCHUNG M.B.H. - W. GERMANY NORBERT FOCKWER

GILBERT/COMMONWEALTH JERRY L. ELLIS
GLOBAL MARINE INC ROBERT F. BAUER

GOLDER ASSOCIATES

DONALD W. CALDWELL

J. W. VOSS

GRAND COUNTY HIGH SCHOOL UBRARY

GRAND COUNTY PUBLC UBRARY

GRIMCO DONALD H. KUPFER

GSE/NUCLEAR OMAHA PUBLIC POWER DISTRICT

JOHN K. NEJAD

GTC GEOLOGIC TESTING CONSULTANTS ITD -

CANADA

JOHN F. PICKENS

GULF STATES UTILTIES COMPANY JOHN E. BARRY

H \& R TECHNICAL ASSOCIATES INC WILLIAM R. RHYNE

H-TECH LABORATORIES INC BRUCE HARTENBAUM

HAHN-METTNER-ANSTITUT FUR

KERNFORSCHUNG BERLIN KLAUS ECKART MAASS

HALEY AND ALDRICH INC JAMES R. LAMBRECHTS

HANFORD ENGINEERING DEVELOPMENT

LABORATORY

ALBERT G. BLASEWITZ

ROBERT EINZIGER

R. L. KNECHT

HARDING LAWSON ASSOCIATES FRANK C. KRESSE

HARRIETTE PERSON MEMORIAL UBRARY

HARRISON COUNTY LBRARY

HART-CROWSER AND ASSOCIATES MICHAEL BAILEY

HARVARD UNIVERSITY CHARLES W. BURNHAM DADE W. MOELLER RAYMOND SIEVER

HATTESBURG PUBLIC LIBRARY

HIGH PLAINS UNDERGROUND WATER DIST TROY SUBLETT

HIGH PLAINS WATER DISTRICT DON MCREYNOLDS DON D. SMITH A. WAYNE WYATT

HIRAM COLLEE JAMES W. COWDEN

HITACHI WORKS, HITACHI LTD MAKOTO KIKUCHI

HOUGH-NORWOOD HEALTH CARE CENTER GEORGE H. BROWN, M.D.

IDAHO BUREAU OF MINES AND GEOLOGY EARL H. BENNETT

IDAHO DEPT OF HEALTH AND WELFARE ROBERT D. FUNDERBURG

ILINOIS DEPT OF NUCLEAR SAFETY TERRY R. LASH

ILLNOIS STATE GEOLOGICAL SURVEY KEROS CARTWRIGHT E. DONALD MCKAY, III

IMPERIAL COULGE OF SCIENCE AND TECHNOLOGY - ENCLAND B. K. ATKINSON NEVILLE J. PRICE

INDIANA STATE BOARD OF HEALTH HAL S. STOCKS

INDIANA UNIVERSITY HAYDN H. MURRAY 
ODUSTRIAL POWER COMPANY ITD -

FINLAND

VEIJO RYHANEN

JUKKA-PEKKA SALO

INSTITUT FUR TEFLAGERUNG - W. GERMANY H. GIES

KLAUS KUHN

E. R. SOLTER

INSTITUTE FOR CHEMICAL TECHNOLOGY - W. GERMANY

REINHARD ODOI

INSTITUTE OF GEOLOGICAL SCIENCES ENGLAND

STEPHEN THOMAS HORSEMAN

INSTITUTE OF RADIATION PROTECTION -

FINLAND

KAI JAKOBSSON

INTERA ENVIRONMENTAL CONSULTANTS INC

F. J. PEARSON, JR.

ROBERT WILEMS

INTERNATIONAL ATOMIC ENERGY AGENCY AUSTRIA

EVERETT R. IRISH

INTERNATIONAL ENERGY ASSOCIATES LTD BLYTHE K. LYONS

INTERNATIONAL ENERGY SYSTEMS CORP JOHN A. BOWLES

INTERNATIONAL ENGINEERING COMPANY INC

TERRY L. STEINBORN

MAX ZASLAWSKY

INTERNATIONAL RESEARCH AND

EVALUATION

R. DANFORD

INTERNATIONAL SALT COMPANY

LEWIS P. BUSH

JOHN VOIGT

NOWA STATE UNIVERSITY MARTIN C. EDELSON

IRT CORP 1. STOKES

ISTITUTO SPERIMENTALE MODEUI E

STRUTTURE S.P.A. - ITALY

NEIL A. CHAPMAN

F. GERA

1. F. T. AGAPITO \& ASSOCIATES INC MICHAEL P. HARDY

J. L. MAGRUDER Q ASSOCIATES J. L. MAGRUDER

MCKSON METROPOUTAN LUBRARY

MCKSON STATE UNIVERSITY ESTUS SMITH

JACKSON-GEORGE REGIONAL LIBRARY

JAPAN ATOMIC ENERGY RESEARCH INSTTUUTE TARO ITO

HARUTO NAKAMURA

JAY L. SMITH COMPANY INC JAY L. SMITH

IGC CORPORATION - IAPAN MASAHIKO MAKINO

JOHNS HOPKINS UNIVERSITY JARED L. COHON

JOINT RESEARCH CENTRE - ITALY FRANCESCO GIRARDI

JONES COUNTY JUNIOR COLLCE UBRARY

JORDAN CORRILL ASSOCIATES JOHN D. TEWHEY

SER ENGINEERS INC

W. I. DODSON

I. S. RITCHIE

KALAMAZOO COLLEG RALPHM. DEAL
KANSAS DEPT OF HEALTH AND

ENVIRONMENT

GERALD W. ALLEN

KANSAS STATE GEOLOCICAL SURVEY WILLIAM W. HAMBLETON

KBS - SWEDEN LARS B. NILSSON

KELER WREATH ASSOCIATES FRANK WREATH

KERNFORSCHUNCSZENTRUM KARLSRUHE GMBH - W. CERMANY

K. D. CLOSS

KIHN ASSOCIATES HARRY KIHN

KIUCORES INC CHARLES KILLGORE

KLM ENGINEERING INC B. GEORGE KNIAZEWYCZ

KYOTO UNIVERSITY - MAPAN YORITERU INOUE

LANCASTER AVENUE LABRARY F. M. CALVARESI

LAW ENGINEERING TESTING COMPANY JAMES L. GRANT

LAWRENCE BERKELEY LABORATORY

JOHN A. APPS

THOMAS DOE

NORMAN M. EDELSTEIN

E. MAIER

ROBIN SPENCER

J. WANG

HAROLD WOLLENBERG

LAWRENCE LUVERMORE NATIONAL

LBORATORY

LYNDEN B. BALLOU

HUGH HEARD

FRANCOIS E. HEUZE

DONALD D. JACKSON

R. CARROLL MANINGER

PAUL L. PHELPS

LAWRENCE D. RAMSPOTT (2)

W. G. SUTCLIFFE

TECHNICAL INFORMATION DEPARTMENT L-53

RICHARD VAN KONYNENBURG

DALE C. WILDER

LEHICH UNIVERSITY

D. R. SIMPSON

LOCKHEED ENGINEERINC \& MANAGEMENT COMPANY

STEVE NACHT

LOS ALAMOS NATIONAL LABORATORY

ERNEST A. BRYANT

P. L. BUSSOLINI

GEORGE A. COWAN

B. Crowe

BRUCE R. ERDAL

WAYNE R. HANSEN

CLAUDE HERRICK

DONALD T. OAKLEY

K. K.S. PILLAY

JOE SMYTH

JOHN T. WHETTEN

KURT WOLFSBERG

LOS ALAMOS TECHNICAL ASSOCLATES INC HELEN F. GRAM

R. J. KINGSBURY

LOS ANGELES PIERCE COLIEGE SIGMUND P. HARRIS

LOUISIANA DEPT OF NATURAL RESOURCES

B. JIM PORTER

FRANK SIMONEAUX
LOUISIANA DEPT OF TRANSPORTATION \& DEVELOPMENT

GEORGE H. CRAMER, II

LOUISIANA GEOLOGICAL SURVEY

CHARLES G. GROAT

SYED HAQUE

LEE W. JENNINGS

LOUISIANA NUCLEAR ENERGY DIVISION L. HALL BOHLINGER (3)

LOUISIANA STATE UNIVERSTTY JEFFREY S. HANOR

JIMMIE H. HOOVER

LOUISIANA TECH UNIVERSITY LIBRARY

LOUISIANA TECHNICAL UNIVERSITY R. H. THOMPSON

LOWENSTEIN, NEWMAN, REIS \& AXELRAD MICHAEL A. BAUSER

MASSACHUSETTS INSTITUTE OF

TECHNOLOCY

JOHN DEUTCH

TED GREENWOOD

MARSHALLVINE

MCMASTER UNIVERSTTY - CANADA

L. W. SHEMILT

MELLEN GEOLOGICAL ASSOCIATES INC FREDERIC F. MELLEN

MEMBERS OF THE GENERAL PUBLIC

DAVID H. BOLTZ

IAMES BOYD

LARRY BRADLEY

IACK BRANDT

STEPHEN S. BRICGS

WILLIAM E. CONAWAY

STEVE CONEWAY

IIM CONKWRIGHT

G. COOKE

DANNELLE D. DUDEK

DOROTHY FORD

CARL A. GIESE

SHIRLEY M. GIFFORD

STEPHEN L. GILLETT

DARYL GLAMANN

OSWALD H. GREAGER

DOUGLAS H. GREENLEE

JOAN GREGOR

KENNETH CUSCOTT

C. F. HAJEK

ARLIE HOWELL

KENNETH S. JOHNSON

RUDOLPH W. KOPF

THOMAS H. LANGEVIN

JOE MADIA

MAX MCDOWELL

A. ALAN MOGHISSI

JAMES B. MUCKERHEIDE

ALAN D. PASTERNAK

SHAILER S. PHILBRICK

MARTIN RATHKE

JOHNNY SLUDER

NORMAN C. SMITH

M. I. SZULINSKI

GORDON THOMPSON

W. VON BLACK

GARY WAGNER

A. E. WASSERBACH

IIMMY L. WHITE RICHARD I. WILLIS

MESA COUNTY PUBLAC LABRARY

GEORGE VAN CAMP

MICHAEL BAKER, IR. INC

C. J. TOUHILL 
MICHIGAN DEPT OF NATURAL RESOURCES R. THOMAS SEGALL

MICHIGAN DEPT OF PUBLIC HEALTH GEORGE W. BRUCHMANN

MICHIGAN DISTRICT HEALTH DEPT NO. 4 EDGAR KREFT

MICHIGAN PUBLIC SERVICE COMMISSION RON CALLEN

MICHIGAN STATE UNIVERSITY WILLIAM C. TAYLOR

MICHIGAN TECHNICAL UNIVERSITY DAE S. YOUNG

MINERALS WEST INC STEVE NIELSON

MINNESOTA ENERGY AGENCY MIKE MURPHY

MINNESOTA GEOLOGICAL SURVEY MATT S. WALTON

MINNESOTA STATE ENERGY AGENCY DAVID BULLER

MISSISSIPPI ATTORNEY GENERALS OFFICE MACK CAMERON

MISSISSIPPI BUREAU OF CEOLOGY MICHAEL B. E. BOGRAD

MISSISSIPPI CITIZENS AGAINST NUCLEAR DISPOSAL

STANLEY DEAN FLINT

MISSISSIPPI DEPT OF ENERGY AND

TRANSPORTATION JOHN W. GREEN (3)

MISSISSIPPI DEPT OF NATURAL RESOURCES ALVIN R. BICKER, IR. CHARLES L. BLALOCK CURTIS W. STOVER

MISSISSIPPI DEPT OF WILDLIFE CONSERVATION KENNETH L. GORDON

MISSISSIPPI EMERGENCY MANAGEMENT AGENCY JAMES E. MAHER

MISSISSIPPI LIBRARY COMMISSION SARA TUBB

MISSISSIPPI MINERAL RESOURCES INSTITUTE MISSISSIPPI POWER \& LIGHT ROBERT SHADDIX

MISSISSIPPI STATE BOARD OF HEALTH EDDIE S. FUENTE GUY R. WILSON

MISSISSIPPI STATE HOUSE OF REPRESENTATIVES

TERRELL BRELAND

E. FRED DOBBINS JERRY OKEEFE

MISSISSIPPI STATE SENATE MARTIN T. SMITH

MISSISSIPPI STATE UNIVERSIT TROY I. LASWELL

MITRE CORP LESTER A. ETTLINGER

MOBAY CHEMICAL CORP KENNETH H. HASHIMOTO

MONTICELLO HICH SCHOOL LIBRARY MEDIA CENTER

NACRA - SWITZERLAND MARLIES KUHN

NATIONAL ACADEMY OF SCIENCES JOHN T. HOLLOWAY HAROLD L. JAMES
NATIONAL AERONAUTICS AND SPACF ADMINISTRATION MICHAEL R. HELFERT

NATIONAL BOARD FOR SPENT NUCLEAR

FUEL, KARNBRANSLENAMDEN - SWEDEN NILS RYDELL

NATIONAL BUREAU OF STANDARDS LEWIS H. GEVANTMAN WILLIAM P. REED

NATIONAL HYDROLOGY RESEARCH

INSTITUTE - CANADA DENNIS J. BOTTOMLEY

NATURAL RESOURCES DEFENSE COUNCIL THOMAS B. COCHRAN

NEVADA OFFICF OF COMMUNITY SERVICES J. HAWKE

NEW ENGLAND NUCLEAR CORP

KERRY BENNERT CHARLES B. KILLIAN

NEW IERSEY DEPT OF ENVIRONMENTAL PROTECTION JEANETTE ENG

NEW MEXICO BUREAU OF GEOLOGY BILL HATCHELL

NEW MEXICO BUREAU OF MINES AND MINERAL RESOURCES

FRANK E. KOTTLOWSKI

NEW MEXICO ENVIRONMENTAL EVALUATION GROUP

ROBERT H. NEILL

NEW YORK DEPT OF HEALTH DAVID AXELROD, M.D.

NEW YORK ENERGY RESEARCH \& DEVELOPMENT AUTHORITY JOHN P. SPATH (8)

NEW YORK GEOLOCICAL SURVEY ROBERT H. FAKUNDINY

NEW YORK POWER AUTHORITY MYRONM KACZMARSKY

NEW YORK STATE ELECTRIC \& GAS CORP LEWIS L. STALEY

NEW YORK STATE ENMRONMENTAL FACILITES CORP PICKETT T. SIMPSON

NEW YORK STATE ERDA JOHN C. DEMPSEY

NEW YORK STATE GEOLOGICAL SURVEY ROBERT H. FICKIES

NEW YORK STATE PUBLIC SERVICE COMMISSION FRED HAAG

NEW YORK UNIVERSITY MEDICAL CENTER MERRIL EISENBUD

NIEDERSACHSISCHES SOZALMINISTERIUM W. GERMANY HORST SCHNEIDER

NORTH CAROLNA CONGERVATION COUNCI: IANE SHARP

NORTH CAROLNA STATE UNIVERSITY M. KIMBERLEY

NORTH DAKOTA STATE UNIVERSITY IOHN M. HALSTEAD

NORTHEAST FOUR COUNTY REGIONAL PLANNINC \& DEVELOPMENT

ORGANIZATION

JOHN C. PIERSON

NORTHEAST UIUTIES SERVICE CO PATRICIA ANN OCONNELL

NORTHWESTERN UNIVERSTTY BERNARD I. WOOD
NTR GOVERNMENT SERVICES THOMASV. REYNOLDS

NUCLEAR ASSURANCE CORP JOHN V. HOUSTON IEAN RION

NUCLEAR ENERGY AGENCY/OECD - FRANCE ANTHONY MULLER

NUCLEAR INFORMATION AND RESOURCE SERVICE GARY HZKOWITZ

NUCLEAR SAFETY RESEARCH ASSOCIATION IZUMI KURIHARA

NUCLEAR WASTE WATCHERS HELEN LETARTE

NUS CORP

W. G. BELTER IOSEPH J. DINUNNO DOUGLAS D. ORVIS YONG M. PARK

NUTECH ENCINEERS INC GARRISON KOST

NWT CORP W. L. PEARL

OAK RIDGE NATIONAL LABORATORY

CARLOS E. BAMBERGER

J. O. BLOMEKE

H. C. CLAIBORNE

ALLEN G. CROFF

LESLIE R. DOLE

JOHN T. ENSMINGER

CATHY S. FORE

DAVID C. KOCHER

T. F. LOMENICK

E. B. PEELLE

ARTHUR 1. SHOR

ELLEN D. SMITH

STEPHEN S. STOW

OHIO DEPT OF HEALTH

ROBERT M. QUILLIN

OKLAHOMA GEOLOGICAL SURVEY CHARLES J. MANKIN

OKLAHOMA STATE DEPT OF HEALTH R. L. CRAIG

ONTARIO HYDRO - CANADA

R. W. BARNES

K. A. CORNELL

C. F. LEE

ONTARIO MINISTRY OF THE ENYIRONMENT -CANADA JAAK VIIRLAND

OPEN EARTH - ENGLAND PETER J. SMITH

ORANGE COUNTY COMMUNTTY COUECE LAWRENCE E. OBRIEN

OREGON DEPT OF ENERGY DONALD W. GODARD MICHAEL W. GRAINEY

ORGANISATION FOR ECONOMIC COOPERATION AND DEVELOPMENT -FRANCE

J. P. OUIVIER

OTHA INC

JOSEPH A. LIEBERMAN

P.O.W.E.R.

RALPH DILLER

ACIFIC NORTHWEST LABORATORY

DON J. BRADLEY

H. C. BURKHOLDER

L. L. CLARK

HARVEY DOVE

I. H. JARRETT 
$\bigcup^{2}$

MAXR. KREITER

DONALD E. LARSON

ROBERT MCCALLUM

R. WILLIAM NELSON

R. E. NIGHTINGALE

J. M. RUSIN

R. JEFF SERNE

PARSONS BRINCKERHOFF QUADE *

DOUGLASINC

T. R. KUESEL

ROBERT PRIETO

MARK E. STEINER

PB-KBB INC

JUDITH C. HACKNEY

PENNSYLVANIA COVERNORS ENERGY COUNCIL.

HERBERT JACOBS

PENNSYLVANIA OFFICE OF VOCATIONAL REHABILITATION ANDREW CHOPAK

PENNSYLVAIJIA STATE UNIVERSITY WILLIAM A. JESTER DELLAM. ROY WILLIAM B. WHITE

PENNSYIVANIA TOPOGRAPHIC \& GEOLOGICAL SURVEY ARTHUR A. SOCOLOW

PERMIAN BASIN RECIONAL PLANNING COMMISSION

E. W. CRAWFORD

PERRY COUNTY BOARD OF SUPERVISORS PAUL D. IOHNSTON, SR

PERRY COUNTY CITIZINSS AGAINST NUCLEAR WASTE DISPOSAL

WARREN STRICKLAND

PETTIS WALLEY

PERRY COUNTY SCHOOLS

MANIEL A. COCHRAN

PHYSIKALISCH-TECHNISCHE BUNDESANSTALT

-W. GERMANY

PETER BRENNECKE

PINE FOREST REGIONAL LIBRARY

POINT BEACH NUCLEAR PLANT JAMES J. ZACH

PORTLAND GENERAL ELECTRIC J. W. LENTSCH

POTASH CORP OF SASKATCHEWAN CANADA

GRAEME G. STRATHDEE

POWER REACTOR AND NUCLEAR FUEL

DEVELOPMENT CORPORATION - JAPAN

PRESQUE ISLE COURTHOUSE

PUBLIC LAW UTIITIES GROUP DORIS FALKENHEINER

PUBUIC SERVICE INDIANA ROBERT S, WEGENC

PURDUE UNIVERSITY

PAUL S. LYKOUDIS

QUADREX CORP FRANCIS J. KENESHEA

R. I. SHLEMON AND ASSOCIATES INC R. J. SHLEMON

RADIAN CORP

BARBARA MAXEY

RADIATION PROTECTION COUNCIL

TERI L. VIERIMA

DADIOACTIVE WASTE REYIEW BOARD, STATE WISCONSIN

AME SCHAEFER

RANDALI COUNTY LBRARY

RE/SPEC INC

GARY D. CALLAHAN

PAUL F. GNIRK

WILLIAM C. MCCLAIN
RENSSELAER POLVTECHNIC INSTITUTE

JAMES WU

RHOADS MEMORIAL LIBRARY

RICHTON CITY HALL

R. RAHAIM

RIDIHALCH, ECGERS \& ASSOCIATES INC PHILIP E. EGGERS

RIO ALGOM CORP

DUANE MATLOCK

RISO NATIONAL LABORATORY - DENMARK LARS CARLSEN

ROCKWELL HANFORD OPERATIONS

RONALD C. ARNETT

R. A. DEJU

GEORGE C. EVANS (2)

L. R. FITCH

R. I. GIMERA

KARL M. LA RUE

K. THIRUMALAI

DAVE A. TURNER

ROCKWELL INTERNATIONAL ENERGY SYSTEMS GROUP

LAWRENCE J. SMITH

ROGERS \& ASSOCIATES ENGINEERING CORP ARTHUR SUTHERLAND

ROGERS, COLDEN \& HALPERN JACK A. HALPERN

ROY F. WESTON INC MICHAEL V. MELLINGER HARRY W. SMEDES

ROYAL INSTITUTE OF TECHNOLOCY SWEDEN IVARS NERETNIEKS

S. E. LOGAN \& ASSOCIATES INC STANLEY E. LOGAN

S. M. STOLLER CORP ROBERT W. KUPP

SALT LAKE CITY PUBLIC LIBRARY

SAN DIEGO GAS \& ELECTRIC COMPANY LOUIS BERNATH

SAN JOSE STATE UNIVERSITY SCHOOL OF ENGINEERING

R. N. ANDERSON

SAN JUAN COUNTY LIBRARY

SANDIA NATIONAL LABORATORIES LIBRARY

G. C. ALLEN

KEN BEALL

SHARLA BERTRAM

C. D. BROYLES

C. L. CHRISTENSEN

MARGARET S. CHU

JOE A. FERNANDEZ

NANCY C. FINLEY

R. L. HUNTER

THOMASO. HUNTER

I. KEITH JOHNSTONE

R. W. LYNCH

MARTINA. MOLECKE

JAMES T. NEAL

E. I. NOWAK

SCOTT SINNOCK

A. W. SNYDER

A. E. STEPHENSON

IYNN D. TYLER

WOLFGANG WAWERSIK

WENDELL D. WEART

WIPP CENTRAL FILES

SAVANNAH RIVER LABORATORY

E. J. HENNELLY

CAROL JANTZEN

WILLIAM R. MCDONELL

DONALD ORTH
SCIENCE APPUCATONS INC

JEFFREY ARBITAL

JERRY J. COHEN

NADIA DAYEM

MICHAEL B. GROSS

JAMES E. HAMMELMAN

DEAN C. KAUL

I. ROBERT LARIVIERE

DAVID H. LESTER

PETER E. MCGRATH

JOHN E. MOSIER

HOWARD PRATT

MICHAEL E. SPAETH

KRISHAN K. WAHI

ROBERT A. YODER

SENECA COUNTY DEPT OF PLANNING \& DEVELOPMENT

SHAFER EXPLORATION COMPANY WILLIAM E. SHAFER

SHANNON \& WILSON INC HARVEY W. PARKER

SHIMIZU CONSTRUCTION COMPANY LTD IUNII TAKAGI

SHIMIZU CONSTRUCTION COMPANY ITD -

IAPAN

TAKASHI ISHII

SIERRA CLUB

MARVIN RESNIKOFF

SIERRA CLUB - COLORADO OPEN SPACE

COUNCIL

ROY YOUNG

SIERRA CLUB - MISSISSIPPI CHAPTER

SIX-COUNTY COMMISSIONERS

ORGANIZATION

G. ALLEN FAWCETT

SOGO TECHNOLOGY INC TIO C. CHEN

SOUTH CAROLINA GEOLOGICAL SURYEY NORMAN K. OLSON

SOUTH DAKOTA OFFICE OF ENERGY POUCY STEVEN M. WEGMAN

SOUTHWEST RESEARCH AND INFORMATION CENTER

DON HANCOCK

ALISON P. MONROE

ST. BONAVENTURE UNIVERSTTY CARL J. TWAROC

ST. JOSEPH COLLEGE CLAIRE MARKHAM

ST. MARTIN HIGH SCHOOL RAYMOND I. WERTHNER

STANFORD UNIVERSITY KONRAD B. KRAUSKOPF IRWIN REMSON

STATE UNIVERSITY OF NEW YORK AT BINGHAMTON

FRANCIS T. WU

STATE UNIVERSITY OF NEW YORK COLLEGE AT CORTLAND JAMES E. BUGH

STEADMAN \& HECTOR, PA ALICE G. HECTOR

STEARNS-ROGER SERVICES INC VERYL ESCHEN

STONE \& WEBSTER ENGINEERING CORP JOHN H. PECK ARLENE C. PORT EVERETT M. WASHER

STUDIO GEOLOGICO FOMAR - ITALY A. MARTORANA

STUDSVIK ENERGITEKNIK AB - SWEDEN ROLF SJOBLOM 
SUMMIT COUNTY ENVIRONMENTAL SERVICES JAMES T. KING

SWANSON ENVIRONMENTAL INC PETER G. COLLINS

SWEDISH GEOLOCICAL LIBRARY

SWISHER COUNTY LIBRARY

SWISS FEDERAL OFFICE OF ENERGY U. NIEDERER CHAKRABORTY SABYASACHI

SYRACUSE UNIVERSITY WALTER MEYER

SYSTEM DEVELOPMENT CORP RICHARD BALSAM H. G. DAVIS

SYSTEMS SCIENCE AND SOFTWARE PETER LAGUS

T. M. GATES INC TODD M. GATES

TECHNICAL INFORMATION PROJECT DONALD PAY

TECHNICAL RESEARCH CENTRE OF FINLAND OLLI J. HEINONEN SILJA RUMMUKAINEN KARI SAARI SEPPO VUORI

TECHNICAL SERVICES AND INSTRUMENTATION INC BURTON ANDREPONT

TEKNEKRON RESEARCH INC DOUGLASK. VOGT

TELEDVNE PIPE TOBY A. MAPLES

TENNESSEE DEPT OF PUBLCC HEALTH BILL GRAHAM

TERA CORP LAWRENCE H. WIGHT

TERRA TEK INC NICK BARTON DANIEL D. BUSH

TERRAMETRICS INC HOWARD B. DUTRO

TEXAS A \& M UNIVERSITY P. DOMENICO JOHN HANDIN ROY W. HANN, JR. STEVE MURDOCK GARY ROBBINS JAMESE. RUSSELL

TEXAS DEPT OF HEALTH DAVID K. LACKER

TEXAS DEPT OF WATER RESOURCES

C. R. BASKIN ALFRED DAREZZO

TEXAS ENERGY \& NATURAL RESOURCES ADVISORY COUNCIL TERRY BARRON

TEXAS ENERCY COORDINATORS OFFICE ARNULFO ORTIZ

TEXAS FARM BUREAU RESEARCH DEPT

W. C. WEDEMEYER

TEXAS COVERNORS OFFICE STEVE FRISHMAN

TEXAS COVERNORS OFFICE OF GENERAL COUNSEL

R. DANIEL SMITH

TEXAS HOUSE OF REPRESENTATIVES BRINCK KERR

TEXAS STATE HOUSE OF REPRESENTATIVES PETE LANEY
THE AEROSPACE CORPORATION PETER J. ALEXANDRO

THE ANALTIC SCIENCES CORP JOHN W. BARTLETT CHARLES M. KOPLIK

THE BARTON CHRONICLE CHRIS BRAITHWAITE

THE BENHAM GROUP KEN SENOUR

THE MACKSON CLARION-LEDGER MARK SCHLEIFSTEIN

TRANSNUCLEAR INC BILL R. TEER

TRENDS PUBLISHING INC

IRINITY EPISCOPAL. CHURCH BENJAMIN F. BELL

TRU WASTE SYSTEMS OFFICE K. V. GILBERT

TRW INC PETER ALEXANDER E. R. CHRISTIE

TUN ISMAIL ATOMIC RESEARCH CENTRE (PUSPATI) SAMSURDIN BIN AHAMAD

U.H.D.E. - W. GERMANY FRANK STEINBRUNN

U.S. ARMY CORPS OF ENGINEERS DON BANKS ALAN BUCK

U.S. BUREAU OF LAND MANAGEMENT IYNN JACKSON

MARY PLUMB EDWARD R. SCHERICK GREGORY F. THAYN

U.S. EUREAU OF MINES GEORGE E. NIEWIADOMSKI

U.S. QUREAU OF RECLAMATION REGE LEACH

U.S. DEPT OF COMMERCE PETER A. RONA

US. DEPT OF ENERCY CHED BRADLEY S. H. GREENLEICH LAWRENCE H. HARMON EDWARD F. MASTAL IAMES TURI

U.S. DEPT OF ENERGY - ALBUQUERQUE OPERATIONS OFFICE PHILIP LARRAGOITE R. LOWERY JOSEPH M. MCGOUGH DORNER T. SCHUELER

U.S. DEPT OF ENERGY - CHICAGO OPERATIONS OFFICE VICKI ALSPAUGH D. BRAY DUANE DAY

PAUL KEARNS

PUBLIC READING ROOM R. SELBY

U.S. DEPT OF ENERGY - CRYSTALINE ROCK PROJECT OFFICE STEVEN A. SILBERGLEID

U.S. DEPT OF ENERGY - DALLAS SUPPORT OFFICE

CURTIS E. CARLSON, JR.

U.S. DEPT OF ENERGY - DIVISION OF WASTE REPOSITORY DEPLOYMENT

CYRUS KLINGSBERC JEFF SMILEY
U.S. DEPT OF ENERCY - GEOLOCIC REPOSITORY DIVISION

J. W. BENNETT

C. R. COOLEY (2)

WARREN EISTER

J. FIORE

CRITZ H. GEORGE

RALPH STEIN

U.S. DEPT OF ENERGY - HEADQUARTERS PUBLIC READING ROOM

U.S. DEPT OF ENERGY - DAHO OPERATIONS OFFICE

CARL P. GERTZ

JAMES F. LEONARD

PUBLIC READING ROOM J. H. SAKO

U.S. DEPT OF ENERGY - NEVADA OPERATIONS OFFICE

PUBLIC READING ROOM

U.S. DEPT OF ENERGY - NUCLEAR

ENVIRONMENTAL APPLICATION ERANCH ROBERT W. BARBER

U.S. DEPT OF ENERCY - NUCLEAR WASTE POLICY ACT OFFICE ROBERT M. ROSSELLI JANIE SHAHEEN

U.S. DEPT OF ENERGY - NWTS PROGRAM OFFICE

J. O. NEFF

U.S. DEPT OF ENERGY - OAX RIDGE

OPERATIONS OFFICE PUBLIC READING ROOM

U.S. DEPT OF ENERGY - OFFICE OF BASIC ENERCY SCIENCES MARK W. WITTELS

U.S. DEPT OF ENERCY - OFFICE OF ENERCY RESEARCH

FRANK I. WOBBER

U.S. DEPT OF ENERGY - OFFICE OF NUCLEAR FUEL CYCLE

O. P. CORMLEY

U.S. DEPT OF ENERGY - OFFICE OF PROIECT AND FACIUTIES MANAGEMENT D. L. HARTMAN

U.S. DEPT OF ENERGY - RECION VUI SIGRID HIGDON

U.S. DEPT OF ENERGY - RICHLAND OPERATIONS OFFICE

O. L. OLSON

J. SCHREIBER

D. J. SQUIRES

U.S. DEPT OF ENERGY - SAN FRANCISCO

operations OfFICE ENERGY RESOURCES CENTER PUBLIC READING ROOM

U.S. DEPT OF ENERCY - SAVANNAH RJVER OPERATIONS OFFICE T. B. HINDMAN

U.S. DEPT OF ENERCY - TECHNICAL INFORMATION CENTER (317)

U.S. DEPT OF LABOR ALEX G. SCIULLI KELVIN K. WU

U.S. ENVIRONMENTAL PROTECTION AGENCY DIVISION OF CRITERIA \& STANDARDS JAMES NEIHEISEL

U.S. FOREST SERVICE JOSEPH E. CLAYTON

U.S. GENERAL ACCOUNTING OFFICE WILLIAM DAVID BROOKS CHARLES D. MOSHER 
S. GEOLOGICAL SURVEY VIRGINIA M. GLANZMAN

U.S. GEOLOGICAL SURVEY - ALEXANDRIA G. N. RYALS

U.S. GEOLOGICAL SURVEY - BATON ROUGE DARWIN KNOCHENMUS

US. GEOLOGICAL SURVEY - COLUMBUS A. M. LA SALA, JR.

U.S. GEOLOGICAL SURVEY - DENVER

ALBERT H. BALCH

M.S. BEDINGER

JESS M. CLEVELAND

JULES D. FRIEDMAN

ROBERT J. HITE

W. SCOTT KEYS

RAYMOND D. WATTS

U.S. GEOLOCICAL SURVEY - JACKSON GARALD G. PARKER, IR.

U.S. GEOLOGICAL SURVEY - MENLO PARK MICHAEL CLYNNE

ARTHUR H. LACHENBRUCH JACOB RUBIN

U.S. GEOLOGICAL SURVEY - RESTON

I-MING CHOU

JOHN ROBERTSON

EDWIN ROEDDER

EUGENE H. ROSEBOOM, JR.

PETER R. STEVENS

DAVID B. STEWART

NEWELL J. TRASK, JR.

U.S. HOUSE SUBCOMMITTEE ON ENERCY AND

THE ENVIRONMENT

MORRIS K. UDALL

U.S. NUCLEAR RECULATORY COMMISSION

J. CALVIN BELOTE

R. BOYLE

PATRICIA A. COMELLA

ENRICO F. CONTI

F. R. COOK

JULIA ANN CORRADO

J. J. DAVIS

DOCKET CONTROL CENTER

PAUL F. GOLDBERG

HIGH-LEVEL WASTE LICENSING BRANCH

HIGH-LEVEL WASTE TECH. DEVELOP.

BRANCH

ROBERT JOHNSON

CLYDE JUPITER

PHILIP S. JUSTUS

MICHAEL S. KEARNEY

H. E. LEFEVRE

LIBRARY

IOHN C. MCKINLEY

THOMAS J. NICHOLSON

EDWARD OCONNELL

EDWARD REGNIER

JAYE. RHODERICK

R. IOHN STARMER

MICHAEL WEBER

KRISTIN B. WESTBROOK

U.S. SENATE COMMITTEE ON ENERGY AND

NATURAL RESOURCES

WILLIS D. SMITH

UHDE GMBH - W. GERMANY OLINGER

UNC NUCLEAR INDUSTRIES

ED POWERS

- INION CARBIDE CORP

JOHN D. SHERMAN

ONION OF CONCERNED SCIENTISTS

MICHAEL FADEN
UNITED KINCDOM DEPT OF THE

ENVIRONMENT

F. S. FEATES

RADIOACTIVE WASTE MANAGEMENT DIVISION

UNIVERSITY OF AKRON

LORETTA J. COLE

UNIVERSITY OF ALABAMA AT BIRMINCHAM J. WALTER MASON

UNIVERSITY OF ALBERTA - CANADA

F. W. SCHWARTZ

UNIVERSITY OF ARIZONA

JAAK DAEMEN

STANLEY N. DAVIS

IAMES G. MCCRAY

ROY C. POST

UNIVERSITY OF CALIFORNIA AT BERKELEY TODD LAPORTE

UNIVERSITY OF CALUFORNIA AT LOS ANGELES D. OKRENT

UNIVERSITY OF CALIFORNIA AT RIVERSIDE LEWIS COHEN

UNIVERSITY OF CALIFORNIA AT SANTA CRUZ JOEL PRIMACK

UNIVERSITY OF CINCINNAT ATTILA KILINC

UNIVERSTY OF DELAWARE FRANK A. KULACKI

UNIVERSITY OF FLORIDA

DAVID E. CLARK

DOLORES C. JENKINS M. J. OHANIAN

UNIVERSITY OF HAWAII AT MANOA DAVID EPP

UNIVERSITY OF ILINOIS AT URBANA CHAMPAIGN

DANIEL F. HANG

ALBERT I. MACHIELS

MAGDI RAGHEB

UNIVERSTTY OF LOWELL IAMES R. SHEFF

UNIVERSITY OF MICHICAN RICHARD C. PORTER

UNIVERSITY OF MISSISSIPPI GEORGE D. BRUNTON

UNIVERSTTY OF MISSOURI AT COLUMBIA W. D. KELLER

UNIVERSITY OF MISSOURI AT KANSAS CITY EDWIN D. COEBEL

UNIVERSITY OF MISSOURI AT ROLLA ALLEN W. HATHEWAY ARVIND KUMAR

UNIVERSITY OF NEVADA AT RENO RODNEY J. WEICK

UNIVERSITY OF NEW MEXICO DOUGLAS G. BROOKINS RODNEY C. EWING

UNIVERSITY OF NOTRE DAME JOHN LUCEY

UNIVERSITY OF OKLAHOMA DANIEL T. BOATRIGHT

UNIVERSITY OF OTTAWA - CANADA TUNCER OREN

UNIVERSITY OF PENNSYLVANIA R. IAN HARKER

UNIVERSITY OF RHODE ISLAND EDWARD P. LAINE
UNIVERSITY OF SOUTHERN MISSISSIPPI CHARLES R. BRENT

FRED HOWELL

JAMES W. PINSON

DANIEL A. SUNDEEN

GARY C. WILDMAN

UNIVERSITY OF TENNESSEE AT KNOXVILLE DON W. BYERLY

I. B. FUSSELL

UNIVERSITY OF TEXAS AT AUSTIN

PAUL ANAEIIONU

BUREAU OF ECONOMIC GEOLOGY

THOMAS C. GUSTAVSON

MARTIN P. A. JACKSON

JOE O. LEDBETTER

DOUGLAS C. RATCLIFF

E. G. WERMUND

UNIVERSITY OF TEXAS AT SAN ANTONIO DONALD R. LEWIS

UNIVERSITY OF TEXAS GENERAL LBRARY

UNIVERSITY OF TOKYO - JAPAN RYOHEI KIYOSE

UNIVERSITY OF TORONTO - CANADA R. M. STESKY

UNIVERSITY OF UTAH MARRIOTT LIBRARY GARYM. SANDQUIST RODGER WEAVER

UNIVERSITY OF UTAH MEDICAL CENTER JAMES A. SORENSON

UNIVERSITY OF UTAH RESEARCH INSTITUTE LIBRARY

DUNCAN FOLEY

HOWARD P. ROSS

UNIVERSITY OF WASHINGTON

DAVID BODANSKY M. A. ROBKIN

UNIVERSITY OF WESTERN ONTARIO -

CANADA

WILLIAM S. FYLE

UNIVERSITY OF WISCONSIN

B. C. HAIMSON

UNIVERSITY OF WISCONSIN - MILWAUKEE SARUP

LYNNE B. JUDD

UNIVERSITY OF WISCONSIN AT MILWAUKEE HOWARD PINCUS

URS/JOHN A. BLUME \& ASSOCIATES, ENCINEERS

ANDREW B. CUNNINGHAM

UTAH BUREAU OF RADIATION CONTROL DARRELL M. WARREN

UTAH DIVISION OF PARKS \& RECREATION GORDON W. TOPHAM

UTAH GEOLOGICAL AND MINERAL SURVEY GENEVIEVE ATWOOD MAGE YONETANI

UTAH SCIENCE COUNCIL RANDY MOON

UTAH SOUTHEASTERN DISTRICT HEAITH

DEPARTMENT ROBERT L. FURLOW

UTAH STATE UNIVERSTTY DEPT OF GEOLOGY 07 JOEL E. FLETCHER

UTAH WILDERNESS ASSOCIATION MIKE PALMER

UTLITY DATA INSTITUTE FRED YOST

VANDERBILT UNIVERSITY FRANK L. PARKER 
VERMONT DEPT OF WATER RESOURCES AND ENVIRONMENTAL ENGINEERING CHARLES A. RATTE

VERMONT STATE NUCLEAR ADVSORY PANEL VIRGINIA CALLAN

VIRGINIA DEPT OF HEALTH ROBERT C. WICKLINE

VIRGINIA DIVISION OF MINERAL RESOURCES ROBERT C. MILICI

VIRGINIA POLVTECHNICAL INSTITUTE AND

STATE UNIV

GARYL. DOWNEY

WASHINGTON DEPT OF SOCIAL AND HEALTH SERVICES

T. STRONG

WASHINGTON HOUSE OF REPRESENTATIVES RAY ISAACSON

WASHINGTON STATE SENATE DONN CHARNLEY

WASHINGTON STATE UNIVERSITY GEORGIA YUAN

WATTLAB

BOB E. WATT
WAYNE STATE UNIVERSITY

JAMES A. WOODYARD

WBAI-FM

WARREN LIEBOLD

WEBSTER PARISH UBRARY

WEST DADE REGIONAL LIBRARY

LOURDES BLANCO LOPEZ

WEST VALLEY NUCLEAR SERVICES CO INC ERICH J. MAYER

RICHARD M. WINAR

WEST VIRGINIA GEOLOGICAL AND

ECONOMIC SURVEY

ROBERT B. ERWIN

WESTINGHOUSE ELECTRIC CORP

CAROL A. KIZIS

JAMES R. SCHORNHOUST

WIPP PROIECT

WESTINGHOUSE ELECTRIC CORPORATION

WISCONSIN DEPT OF NATURAL RESOURCES DUWAYNE F. GEBKEN
WISCONSIN DIVISION OF STATE ENERGY ROBERT HALSTEAD

WISCONSIN GEOLOGICAL AND NATURAL HISTORY SURVEY

MICHAEL G. MUDREY, JR. MEREDITH E. OSTROM

WISCONSIN PUBLIC SERVICE CORP PAUL WOZNIAK

WOODS ROBERTSON ASSOCIATES - CANADA

WOODWARD-CIYDE CONSULTANTS

F. R. CONWELL (2)

ASHOK PATWARDHAN

WESTERN REGION LIBRARY

WRIGHT STATE UNIVERSITY

A. A. BAKR

WYOMING GEOLOGICAL SURVEY

JAMES C. CASE

YALE UNIVERSITY

BRIAN SKINNER 


\section{COMMENT SHEET}

To the User: The purpose of this sheet is to give you the opportunity to provide feedback to DOE on the usefulness of this report and to critique it. Please submit your comments below and return the sheet.

\section{Comments}

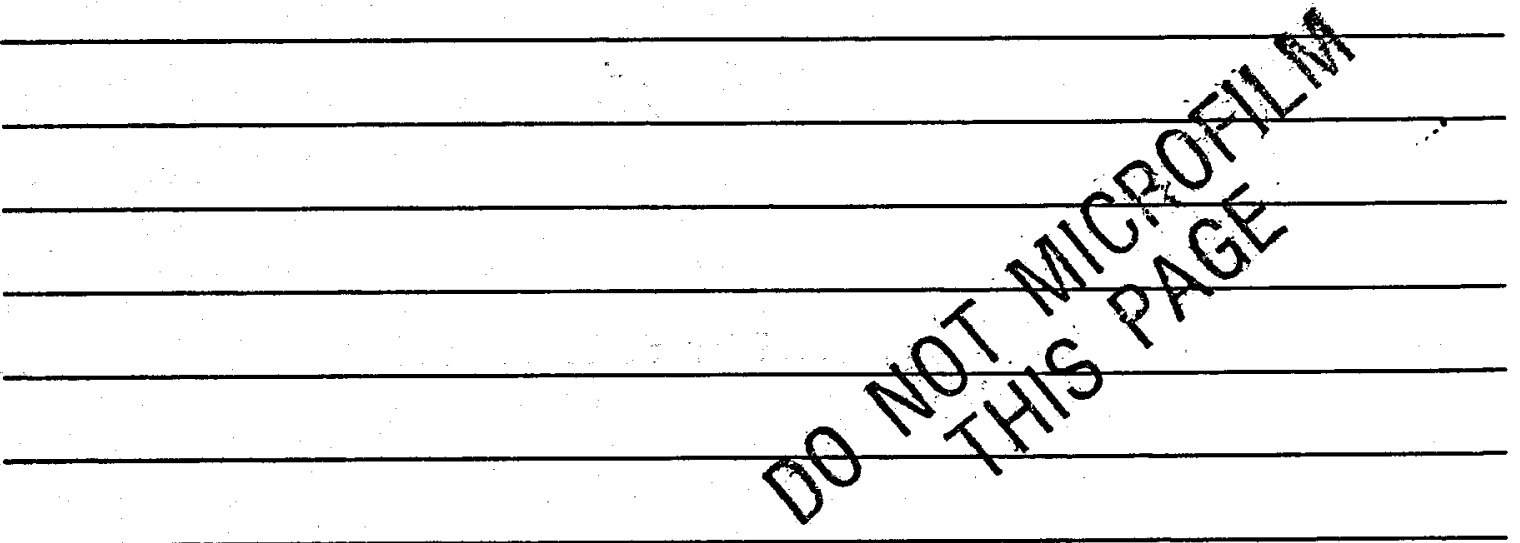

(Use additional sheet if necessary.)

Name

Date

Organization

Street

City State

Telephone Number ( I 


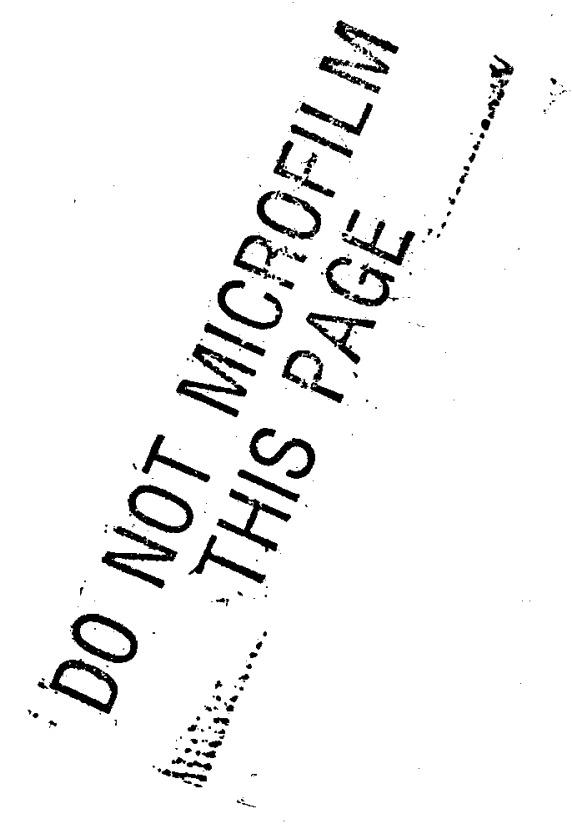

Fold Here

MANAGER, DOE/NPO

505 KING AVENUE

COLUMBUS, OHIO 43201 USA 